\author{
Mariana de Oliveira Pedreira
}

\title{
AVALIAÇÃO DO POTENCIAL DE CONSERVAÇÃO DE ENERGIA ASSOCIADO À PRODUÇÃO E USO DE FERTILIZANTES NITROGENADOS
}

\begin{abstract}
Dissertação apresentada ao Programa Interunidades de Pós-graduação em Energia (IEE/EP/IF/FEA) da Universidade de São Paulo para obtenção do título de Mestre em Energia.
\end{abstract}

São Paulo

outubro 1998 
A todos aqueles que eu amo, em especial a minha avó Esther, por ela não poder estar presente, pelo menos fisicamente, para poder compartilhar comigo esta conquista. 
..." a esperança dança na corda bamba de sombrinha e em cada passo dessa linha pode se machucar, azar"...

João Bosco e Aldir Blanc 


\section{Agradecimentos}

Ao meu orientador Prof. Dr. Ildo Luis Sauer por ter me aberto este vasto e muitas vezes incompreendido caminho, MUITO OBRIGADA!

Aos demais professores do Programa Interunidades de Pós-graduação em Energia/USP por toda colaboração e amizade.

Ao Prof. Dr. José Goldemberg por ter me dado a oportunidade de estudar com o Prof. Dr. Amulya Reddy.

A Antonnete D'Sá pelos ensinamentos e paciência e aos demais membros do Intemational Energy Iniciative - $|E|$.

A queridissima Naza pelo apoio moral e logístico.

Aos colegas do PIPGE: Ksim, Cris, Mara, Camilo, Renata, Telma, Orlando, Róbson e Serginho pela amizade e companheirismo.

Aos funcionários do IEE.

Ao Prof. Dr. Gil Anderi pela atenção dispensada ao meu trabalho.

A Paulo Ávila, Luis Sanches, Benedito Ferreira, Baltazar da Costa e Svend Lyse-Petersen por todas as informações que me forneceram.

Ao Conselho Nacional de Desenvolvimento Cientifico e Tecnológico - CNPq, agradeço por ter proporcionado o apoio financeiro à pesquisa. 


\section{Sumário}

Lista de Tabelas

Lista de Gráficos

Lista de Quadros e Figuras

Resumo

Abstract

\section{CAPÍTULO 1 - INTRODUÇÃO}

1.1. Introdução.

CAPÍtULO 2 - CICLO BIOGEOQUÍMICO DO NITROGÊNIO E SUAS ALTERAÇŌES

2.1. Introdução 3

2.1.1. O Ciclo Global do Nitrogênio.............................................................................. 3

2.1.2. Perturbações Provocadas pela Atividade Humana................................................... 6

2.1.2.1. A Situação do Brasil............................................................................... 10

2.1.3. Consequências do Aumento da Fixação de Nitrogênio..............................................13

2.2. A Preocupação com o Meio Ambiente Associada ao Desenvolvimento

Sustentável. 14

2.2.1. A Relação entre Agricultura e Energia...............................................................17

2.2.1.1 Diretrizes Especificas para Reduzir a Fixação de Nitrogênio................................18

\section{CAPÍTULO 3 - INDÚSTRIA DE FERTILIZANTES NITROGENADOS}

3.1. Considerações Gerais sobre a Indústria de Fertilizantes Nitrogenados................................. 20

3.2. Oferta de Fertilizantes Minerais Nitrogenados e Amônia..................................................... 21

3.2.1. Características do Mercado............................................................................ 21

3.2.1.1. Preços dos FMN e Amônia ..................................................................... 23

3.2.2. Oferta de Nitrogênio no Brasil..................................................................... 26

3.3. Processos Industriais de Fabricação de Amônia........................................................... 33

3.4. Aspectos Ambientais da Produção de Amônia........................................................... 36

3.5. Diagnóstico da Indústria Brasileira de Amônia.............................................................. 37

3.5.1. Indicadores Técnicos do Processo de Produção de Amônia.................................... 42 
3.5.2. Importância da Amônia na Produção de FMN ........................................................ 45

3.6. Potencial de Conservação de Energia........................................................................ 46

3.7. Análise das Possibilidades de Conservação de Energia na Indústria de Amônia................. 52

3.7.1. Metodologia............................................................................................ 52

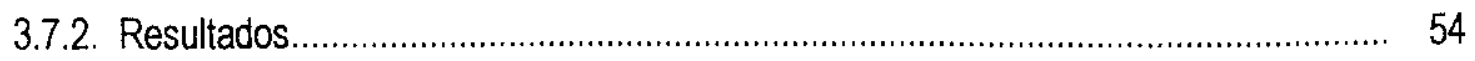

3.7.2.1. Discussão: Curva Cumulativa de Recursos.................................................. 57

CAPÍTULO 4 - CONSTRUÇÃO DE CENÁRIOS DE DEMANDA DE NITROGÊNIO: UM ESTUDO DE CASO DA CULTURA DO MILHO NO BRASIL

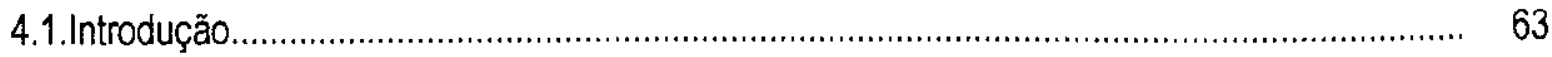

4.1.1. Importância da Cultura do Milho................................................................. . 67

4.2. Consumo de Nitrogênio no Brasil............................................................................. 68

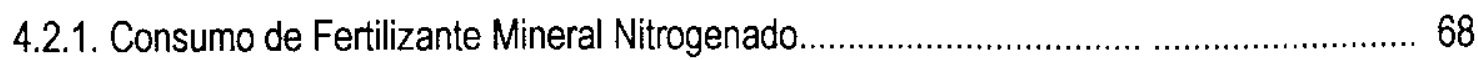

4.2.1.1. Fatores Econômicos Afetando a Demanda....................................................... 72

4.2.2. Oferta e Consumo de Sementes de Adubo Verde................................................... 74

4.3. Medidas para Racionalizar o Uso de Fertilizantes Minerais Nitrogenados........................... 77

4.3.1. Aplicação Eficiente de Fertilizante Mineral Nitrogenado......................................... 77

4.3.1.1. Potencial de Economia de FMN através de Incorporação................................ 79

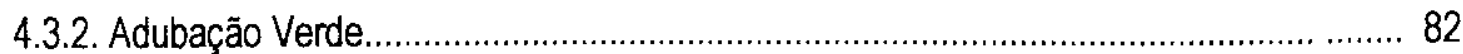

4.3.2.1. Potencial de Fornecimento de Nitrogênio através da Adubação Verde................. 86

4.4. Cenários de Demanda de Nitrogênio: Um Estudo de Caso da Cultura do Milho no

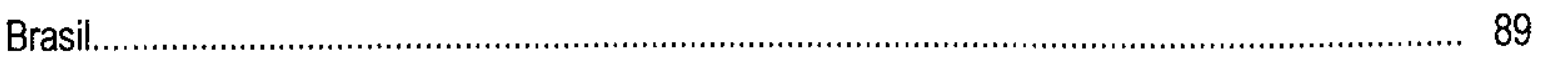

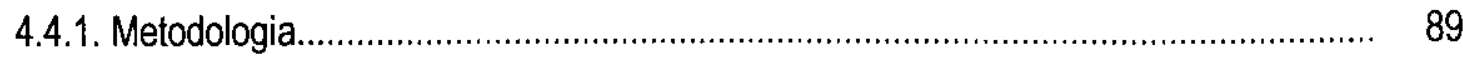

4.4.1.1. Procedimento...................................................................................... 92

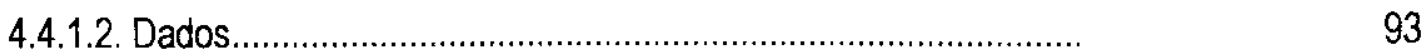

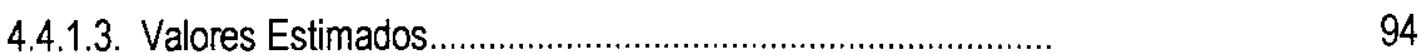

4.4.1.4 Opções de Economia e Oferta de FMN............................................

4.4.2. Cenários de Demanda de Nitrogênio para a Cultura do Milho..................................... 98

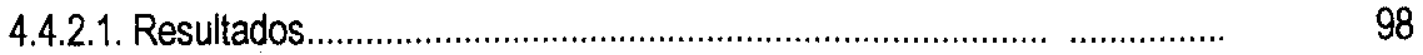

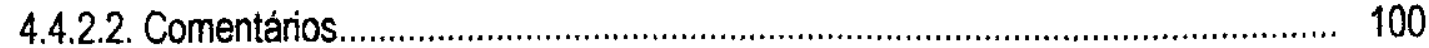

4.4.2.2.a. Cenários sem Crescimento da Área com Milho Utilizando FMN..................... 101

4.4.2.2.b. Cenários com Crescimento da Área com Milho Utilizando FMN..................... 102

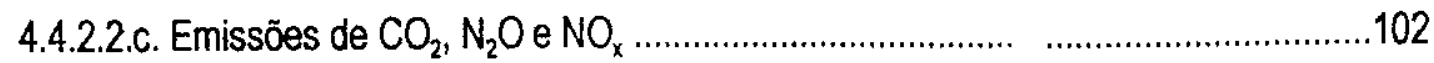


4.4.3. Custos: Metodologia de Cálculo e Resultados................................................ 104

4.4.3.1. Metodologia................................................................... 104

4.4.3.2. Resultados......................................................................

4.4.3.2.a. Opções de Oferta de FMN .................................................................... 105

4.4.3.2.b. Incorporação ao Solo do FMN Aplicado em Cobertura.............................. 105

4.4.3.2.c. Adubação Verde....................................................................................... 106

4.4.3.3. Curva Cumulativa de Recursos para Opções de Oferta e/ou Economia de N-FMN.

\section{CAPÍTULO 5 - CONCLUSÕES}

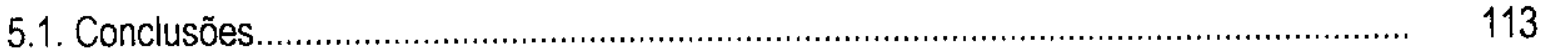

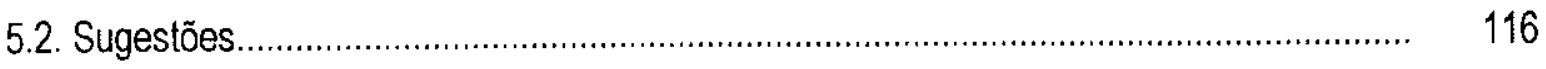

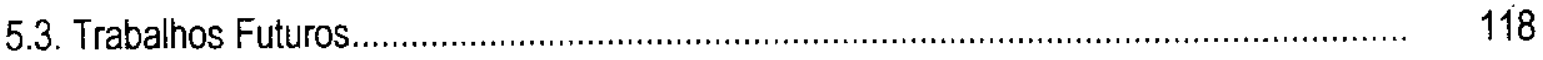

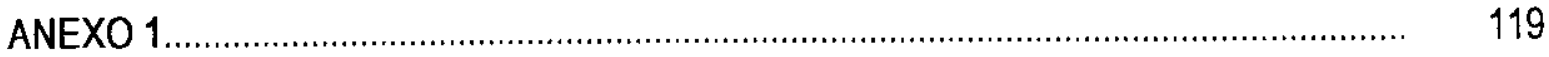

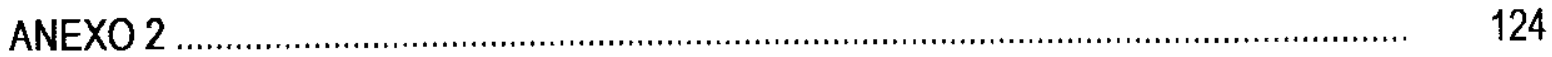

ANEXO 3

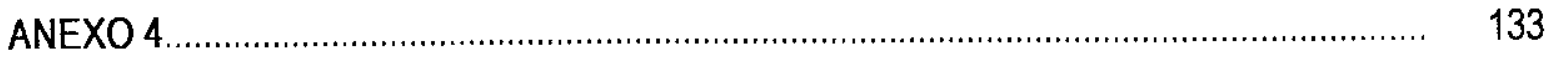

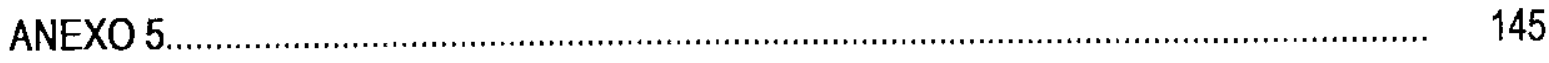

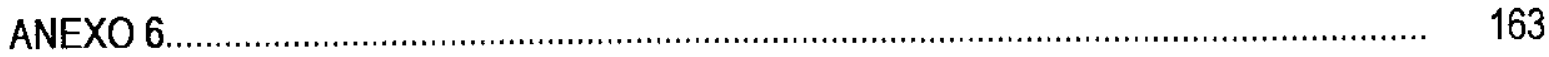

BIBLIOGRAFIA 


\section{Lista de Tabelas}

Tabela 2.1. Média brasileira de produtividade e média atingida por agricultores tecnificados...

Tabela 3.1. Custos de produção de amônia com diferentes matérias-primas em 1996 no noroeste da Europa (1800 t amônia/dia) .......................................................... 24

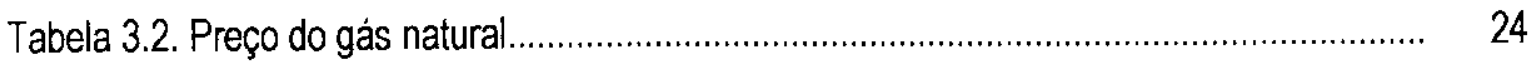

Tabela 3.3. Taxas de crescimento da produção e importação de nitrogênio no Brasil............. 27

Tabela 3.4. Taxas de crescimento da produção, importação e cosnumo aparente de amônia no Brasil

Tabela 3.5. Capacidade de produção e localização das indústrias produtoras........................ 29

Tabela 3.6. Taxa de utilização da capacidade máxima de produção fertilizantes nitrogenados........... 30

Tabela 3.7. Tecnologias empregadas no Brasil pelas unidades de fabricação de amônia para fins fertilizantes......................................................................... 38

Tabela 3.8. Consumos especificos de energia das unidades produtoras de amônia................ 39

Tabela 3.9. Dados obtidos através dos questionários........................................................ 41

Tabela 3.10. Consumo de matérias-primas para a produção de amônia de acordo com a capacidade de produção (base: 330 dias por ano de funcionamento)................. 44

Tabela 3.11. Perda de trabalho em uma unidade de sintese de amônia pelo processo de reforma com vapor d'água utilizando gás natural como matéria -prima.............. 48

Tabela 3.12. Balanço energético e exergético de uma unidade moderna de amônia* (GJ/t $\mathrm{NH}_{3}$ ).

Tabela 3.13. Medidas de conservação de energia para unidades de amônia e o efeito no consumo de energia

Tabela 3.14. CEC da modificação no reator de sintese, unidade Camaçari e Laranjeiras...

Tabela 3.15. CEC da instalação do recuperador de gás de purga por membranas, unidade de Piaçaguera.

Tabela 3.16. CEC da instalação do recuperador de gás de purga,criogênica, unidade de Camaçari e Laranjeiras

Tabela 3.17. CEC da instalação de pré-aquecimento do gás de combustão, unidade de Piaçaguera.

Tabela 3.18. CEC da instalação do pré-aquecimento do gás de combustão, unidade Camaçari......

Tabela 3.19. Preço do gás natural e gás de refinaria 
Tabela 3.20. Medidas de conservação de energia para unidades de amônia viáveis economicamente e o efeito no consumo de energia.....

Tabela 3.21. Economia de matéria-prima atingida com as medidas de conservação de energia......

Tabela 3.22. Efeito da redução do consumo energético na indústria de amônia sobre 0 consumo de energia para produção de fertlizantes.

Tabela 4.1. Participação do custo da adubação na receita de produção (US\$/ha)..... 73

Tabela 4.2. Participação dos fertilizantes no custo operacional e total da cultura do milho..... 74

Tabela 4.3. Produção de sementes para forragens... 75

Tabela 4.4. Comercialização de sementes para adubação verde por cooperativas em SC...... 75

Tabela 4.5. Perdas acumuladas de $\mathrm{N}$-amônia $(\% \mathrm{~N})$ associadas à aplicação supericial de Uréia, Nitrato de amônio (NA) e Uran em dois solos e em três umidades iniciais do solo (Ug/100g).

Tabela 4.7. Capacidade de fornecimento de nitrogênio das leguminosas.

Tabela 4.8. Produção de milho (kg/ha) das safras de 1986, 1987 e 1988 mediante diferentes fontes de nitrogênio.

Tabela 4.9. Rendimento do milho sob diferentes tratamentos relacionados a fonte de nitrogênio

Tabela 4.10. Porcentagem estimada da área com milho, por nível de produtividade, que utiliza FMN durante o periodo de análise (1995 a 2010) nos Cenários Eficiência Congelada Manejo Eficiente, Adubo Verde e Simultâneo.

Tabela 4.11. Demanda de fertilizantes minerais nitrogenados resultante da construção dos cenários

Tabela 4.12. Demanda de amônia derivada dos cenários de demanda de N-FMN.

Tabela 4.13. Demanda de energia derivada da demanda de amônia nos cenários.

Tabela 4.14. Taxas de crescimento da produção e produtividade do milho em todos os cenários, no período de 1995 a 2010

Tabela 4.15. CNE com substituição por adubação verde, sem considerar os custos evitados.

Tabela 4.16. CNE com substituição por adubação verde, considerando os custos evitados.

Tabela 4.17. Necessidade de uso de herbicida e custo/ha ao empregar adubação verde por 10 anos 


\section{Lista de Gráficos}

Gráfico 2.1. Necessidade e consumo total de nitrogênio para algumas culturas - Brasil, 1992

Gráfico 2.2. Nutrientes fornecidos por adubação e retirados do solo pelas colheitas - Brasil, 1994.

Gráfico 3.1. Evolução da produção, importação e consumo aparente de nitrogênio no Brasil.

Gráfico 3.2. Evolução da produção, importação e consumo aparente de amônia no Brasil..

Gráfico 3.3. Utilização da capacidade usual de produção de fertilizantes nitrogenados e amônia. 30

Gráfico 3.4. Preços da amônia no mercado nacional e internacional, 1986 a 1996 31

Gráfico 3.5. Produção e importação de fertilizantes nitrogenados, Brasil - 1995. 32

Gráfico 3.6. Produção e importação de fertilizantes nitrogenados (t de N), Brasil - 1995

Gráfico 3.7. Energia total consumida para fabricação de fertilizantes nitrogenados por tipo de produto, Brasil - 1995.

Gráfico 3.8. Evolução do consumo energético para produção de amônia. 34

Gráfico 3.9. Porcentagem de participação dos insumos com relação ao consumo global do 44 setor nitrogenados

Gráfico 3.10. Consumos especificos de energia por tonelada de produto para produção de fertilizantes nitrogenados simples

Gráfico 3.11. Consumos especificos de energia por tonelada de nitrogênio, para produção de fertilizantes nitrogenados simples.

Gráfico 3.13. Curva do potencial de conservação de energia pelo custo por GJ de cada medida proposta.

Gráfico 3.15. Redução no consumo de energia para produção de fertlizantes devido ao aumento da eficiência energética na indústria de amônia.

Gráfico 4.1. Doses de adubo e seu efeito na produtividade. 65

Gráfico 4.2 Consumo de fertilizantes por cultura, 1992 
Gráico 4.3. Evolução dos indices de produtividade da terra, preços reais de fertilizantes e uso de fertilizantes/a cultivado (1988 $=100)$.

Gráico 4.4. Taxas de crescimento (\%a.a.) da quantidade de FM e nitrogênio consumidos por diferentes culturas (periodo: 1987-95) 70

Gráfico 4.5. Evolução de indices de consumo de nitrogênio (1975=100). 71

Gráficos 4.6 e 4.7. Absorção de $\mathrm{N}$ por plantas de milho em dois solos diferentes e diferentes modos de aplicação de uréia.

Gráfico 4.8. Efeitos da profundidade de aplicação do fertilizante nas perdas por volatilização. $\quad 81$

Gráfico 4.9. Cenários I de demanda de N-FMN. 98

Gráfico 4.10. Cenários II de demanda de N-FMN. 99

Gráfico 4.11. CNE de incorporar o FMN em cobertura sem incluir os custos evitados. 106

Gráfico 4.12. CNE de incorporar o FMN em cobertura incluindo os custos evitados.. 106

Gráfico 4.13. CNE para crotalária incluindo custos evitados com economia de herbicida, comprando sementes anualmente e considerando ou não os custos evitados com a compra de FMN.

Gráico 4.134 CNE para crotalária incluindo custos evitados com economia de herbicida, comprando sementes de 5 em 5 anos e considerando ou não os custos evitados com a compra de FMN.

Gráfico 4.15. Curva cumulativa de recursos considerando o custo da semente de AV sendo comprada anualmente e não considerando os custos evitados.

Gráfico 4.16. Curva cumulativa de recursos considerando o custo da semente de AV sendo comprada anualmente e os custos evitados

Gráico 4.17. Curva cumulativa de recursos considerando o custo da semente de AV sendo comprada a cada cinco anos e não considerando os custos evitados.

Gráfico 4.18. Curva cumulativa de recursos considerando o custo da semente de AV sendo comprada a cada cinco anos e os custos evitados 


\section{Lista de Quadros e Figuras}

Figura 2.1. Ciclo pré-industrial do nitrogênio (milhões de $\mathrm{t} / \mathrm{ano}$ )

Figura 2.2. Ciclo do nitrogênio no periodo atual (milhões de t/ano).

Quadro 3.1. Modificações previstas para as unidades de amônia do Brasil.......................... 39

Quadro 3.2. Medidas de conservação de energia propostas para a indústria de amônia....... 50

Quadro 3.3. Modificações propostas para as unidades de amônia brasileiras..................... 54

Quadro 4.1 Fatores afetando a eficiência da adubação.................................................. 65

Figura 4.1. Processo de fixação do nitrogênio no interior da bactéria................................. 84 


\section{Resumo}

Este trabaho faz uma análise de opções de produção e uso racional de fertilizantes minerais nitrogenados (FMN). Descreve as características do mercado de FMN e dos processos de fabricação de amônia. Efetua um diagnóstico técnico das unidades de amônia brasileiras que empregam o processo de fabricação de reforma com vapor d'água para indicar modificações que proporcionem a diminuição do consumo de matéria-prima e combustivel (combustiveis fósseis). Realiza uma análise econômico-financeira das opções de conservação de energia indicadas pelo diagnóstico. Esta análise demonstra que existe a viabilidade de se efetuarem modificações visando elevar a eficiência energética das unidades de amônia de Camaçari, BA e Laranjeiras, SE, enquanto as modificações propostas para a unidade de amônia de Piaçaguera, SP não apresentaram viabilidade no atual contexto. Apresenta dados de consumo de nitrogênio na agricultura brasileira e descreve opções de utilização deste nutriente pelos agricultores que proporcionam sua utilização racional. Utiliza a metodologia DEFENDUS de construção de cenários para estimar a demanda de nitrogênio e energia derivada do requerimento de FMN para a cultura do milho no Brasil. Calcula os custos para se atender a esta demanda, mediante as opções disponiveis de oferta e economia do nutriente. Apresenta oito cenários de demanda de FMN onde analisa duas medidas de economia: a incorporação dos FMN em cobertura e a substituição total ou parcial da fonte mineral pela adubação verde. Conjuntamente à avaliação das medidas de uso racional, analisa o efeito de se aumentar a proporção da área cultivada com milho que emprega FMN. Conclui que a demanda por nitrogênio na cultura do milho deve crescer para atingir melhores resultados produtivos e que, mesmo com a inserção de outra fonte de nitrogênio e alternativas de manejo eficiente dos FMN, a importação ou a ampliação da capacidade produtiva deste insumo será necessária para atender a demanda nos próximos anos. O manejo eficiente dos FMN propicia uma pequena redução na demanda e pode ser difundido entre os agricultores porque apresenta viabilidade econômica. A adubação verde substitui o consumo de FMN, entretanto, ainda é uma prática de custo mais elevado que a fonte tradicional quando não se consideram os demais beneficios que ela traz ao sistema de produção agrícola. $A$ produção de sementes de adubo verde na propriedade agricola é uma alternativa para viabilizar economicamente a adoção desta técnica. Finalmente, o trabalho analisa as repercussões ambientais relacionadas à produção e ao uso de FMN, faz sugestões de opções para a implementação das medidas de economia do insumo e de trabalhos futuros. 


\section{Abstract}

This work analyzes rational production and utilization of mineral nitrogen fertilizer (MNF). Describes MNF market characteristics and ammonium industrial process. A description of the Brazilian ammonium units state of the art is presented alongside with indication of energy conservation options. A comparative economic analysis among the energy conservation options is performed. This analysis shows the economic feasibility of improving the process energy efficiency of Camaçari, BA and Laranjeiras, SE ammonium plants, while to Piaçaguera, SP ammonium plant modifications are not feasible under current. Brazilian nitrogen consumption data are presented farming rational nitrogen utilization opportunities are described. DEFENDUS scenarios construction methodology is used to estimate the nitrogen and energy demand derived from the MNF requirement for corn in Brazil. Costs to meet this demand through supply and conservation available alternatives are calculated. Scenarios are constructed to evaluate two nitrogen conservation options: the farming process of incorporating the MNF into the soil and the totally or partial substitution of green manure for MNF. Consequences of incrementing proportion of land with corn that utilizes MNF are also evaluated. It is concluded that nitrogen demand for corn must increase to attain best production results and that, even switching the nitrogen source and adopting efficient farming fertilizer application techniques, it will be necessary to import MNF or increase the domestic production capacity to meet the future demand. Although the efficient application of MNF results only in a modest reduction of MNF demand, it is an economically attainable altemative that can be disseminated among the farmers. Green manure has the potential of avoiding MNF consumption, but still is a more expensive option than the MNF when its additional benefits to the agricultural system are not considered. Yielding the green manure seeds at the farm is one choice to reduce its costs. Finally, the work analyzes the environmental effects related to MNF production and use and some suggestions on implementing the MNF saving opportunities are discussed together with the indication of future work. 


\section{INTRODUCÃO}

"Agricultura é a arte de cultivar o Sol".

É cada vez maior a busca pela eficiência na "arte de cultivar o Sol" por causa da demanda crescente por alimentos e outros produtos agricolas simultaneamente à escassez da terra, à necessidade de obtenção de melhores rendimentos financeiros e aos problemas ambientais.

Um importante insumo capaz de elevar os resultados produtivos é o nutriente nitrogênio. Este é considerado essencial para a atividade agricola, sendo responsável pelo crescimento vegetativo das culturas, componente da molécula de clorofila e participando na formação de aminoácidos.

Apesar de ser o componente majoritário da atmosfera, o dinitrogênio não pode ser absorvido pelas plantas. $\mathrm{O}$ processo de fixação é responsável pela transformação do $\mathrm{N}_{2}$ em formas bio-disponiveis. Entretanto, o processo natural de fixação, a fixação biológica através de bactérias, não tem sido capaz de fornecer este nutriente nas quantidades demandadas pela atividade agricola.

A fixação industrial do nitrogênio na forma da indústria de fertilizantes, a partir da década de 40 , tomou-se a fonte mais empregada deste nutriente em todo o mundo. Utilizando hidrocarbonetos (principalmente $\mathrm{CH}_{4}$ ) como fonte de hidrogênio, o $\mathrm{N}_{2}$ da atmosfera, altas pressões e temperaturas, obtém-se a amônia $\left(\mathrm{NH}_{4}\right)$ que, por sua vez, é a base para a fabricação de todos os fertilizantes minerais nitrogenados (FMN).

Nas regiões tropicais porem, os fertilizantes minerais apresentam altas taxas de perdas quando da sua aplicação, em consequência de caracteristicas edafoclimáticas e de seu manejo incorreto.

A fixação extra de nitrogênio pela indústria - empregando como combustivel e matériaprima combustiveis fósseis não renováveis, aliada à ineficiência de aproveitamento agrícola deste nutriente, pode provocar desequilibrios nos ciclos biogeoquímicos tanto do nitrogênio como do carbono.

A contaminação do solo e da água causando modificações bioquímicas como eutrofização ou acidificação e a elevação da quantidade de óxidos de nitrogênio emitidos na atmosfera são fatores apontados como ruptores do equilibrio do ciclo do nitrogênio. 
Quanto ao ciclo do carbono, sabe-se que a queima de combustiveis fósseis, principalmente para geração de energia, é a atividade responsável pela maioria das emissões antrópicas de dióxido de carbono, que é o principal gás causador do efeito estufa. A relação surge então, quando da utilização dos hidrocarbonetos pela indústria de amônia provocando a emissão do dióxido de carbono como resultado da combustão nos processos produtivos.

Apontam-se como distúrbios a dependência do agricultor por um insumo não renovável e a obtenção de baixa eficiência econômica em consequência de sua utilização incorreta.

O objetivo desta dissertação é analisar medidas de redução do consumo energético na produção e no uso de fertilizantes minerais nitrogenados que visam sua utilização racional.

A indústria de amônia no Brasil será o objeto da análise por ser o produto base da fabricação de fertilizantes e a consumidora de hidrocarbonetos. Após um diagnóstico da situação tecnológica deste setor, modificações no processo produtivo que resultem em uma maior eficiência produtiva (menor consumo de matéria-prima e combustiveis) serão avaliadas sob a ótica da viabilidade financeira através de figuras de mérito derivadas das metodologias de análise de projetos.

$\mathrm{Na}$ agricultura, o uso racional de fertilizantes minerais nitrogenados será estudado através da construção de cenários de demanda de nitrogênio para a cultura do milho com a metodologia DEFENDUS (ANEXO 4). Os cenários permitirão verificar o efeito na demanda, da inclusão do que se considera medidas de economia de N-FMN. Para esta dissertação, serão avaliados o manejo correto dos FMN (a incorporação de FMN quando de sua aplicação) e a substituição total ou parcial dos FMN por outra fonte de nitrogênio denominada adubação verde.

O manejo correto dos FMN reduz as perdas e os consequentes efeitos ambientais negativos anteriormente citados.

A adubação verde é uma prática milenar de fornecimento de nitrogênio que foi menosprezada após a difusão dos FMN entre os agricultores. Em termos da quantidade total deste nutriente fixado, pode não haver uma redução com a sua adoção, mas esta fonte não consome hidrocarbonetos para disponibilizá-lo e traz consigo outros beneficios de ordem físico-química e biológica ao sistema de produção agrícola.

Finalmente, também será efetuada uma análise para identificar a viabilidade econômica da adoção destas medidas. 


\section{CICLO BIOGEOQUÍMICO DO NITROGÊNIO E SUAS ALTERACÕ̃ES}

\subsection{Introducão}

O homem está provocando modificações no ciclo global do nitrogênio e provavelmente a melhor evidência disto venha das amostras de ar retiradas das geleiras permanentes do Ártico e da Antártica. Estas foram capazes de indicar a composição atmosférica desde 2000 anos atrás até 0 período atual e os dados mostraram que após 1500 anos de concentração estável de óxido de nitrogênio ( 285 ppbv - 285 moléculas de $\mathrm{N}_{2} \mathrm{O}$ por bilhão de moléculas de atmosfera), a partir do ano 1600 , a quantidade deste gás vem aumentando na atmosfera. Hoje, sua concentração alcança valores maiores do que em qualquer outro periodo e, entretanto, continua crescendo a uma taxa de $0,3 \%$ a.a., indicando que muitos fluxos de nitrogênio estão hoje "mais intensos" do que no período pré-industrial (KINZIG \& SOCOLOW, 1994).

\subsubsection{O Ciclo Global do Nitrogênio}

O elemento nitrogênio é um constituinte essencial de todos os seres vivos, estando presente principalmente nas proteinas e ácidos nucléicos. Pode-se avaliar que as plantas e os animais terrestres e aquáticos deste planeta em conjunto devem ter aproximadamente 15.000.000.000 tN (POSTGADE, 1989).

De uma forma simplificada, o ciclo global do nitrogênio é formado por três grandes reservatórios - a atmosfera, os oceanos e os ecossistemas terrestres - e os fluxos entre eles. Praticamente toda a energia que estimula estes fluxos é derivada do sol - a fotossíntese converte sua energia radiante em energia química, que é finalmente armazenada na forma de matéria orgânica viva e morta.

A quantidade de nitrogênio presente na terra como dinitrogênio - $\mathrm{N}_{2}$ - é imensa; algo como 4.000.000.000 tN na atmosfera e a surpreendente cifra de $2 \times 10^{16} \mathrm{t}$ ligadas em rochas primárias e sedimentares debaixo da superficie (POSTGADE, 1989). 
Porem, as plantas não são capazes de absorver o nitrogênio na forma de $\mathrm{N}_{2}$, apenas umas poucas espécies de bactérias e as algas azuis são capazes de converter o nitrogênio em formas bio-disponiveis $\mathrm{NH}_{4}{ }^{+}$e $\mathrm{NO}_{3}{ }^{-}$através do processo de fixação biológica do nitrogênio. Este é o processo natural mais importante de fixação de nitrogênio no planeta.

$O$ processo onde a molécula de dinitrogênio é reconstituida e retorna para a atmosfera é denominado desnitrificação e, com exceção de uma pequena quantidade que retorna por pirodesnitrificação, este processo também é dependente quase na sua totalidade por outro grupo especializado de bactérias.

Para demonstrar que o ciclo do nitrogênio vem sofrendo distúrbios, AYRES et al. (1994) estimaram em cada etapa do ciclo a quantidade "ciclada" anualmente no periodo pré-industrial e industrial. Para facilitar a compreensão, AYRES et al. (1994) dividem o ciclo do $\mathrm{N}$ em dois subciclos onde a nitrificação é o processo comum entre os dois subciclos (figura 2.1).

Figura 2.1. Ciclo pré-industrial do nitrogênio (milhões de toneladas por ano).

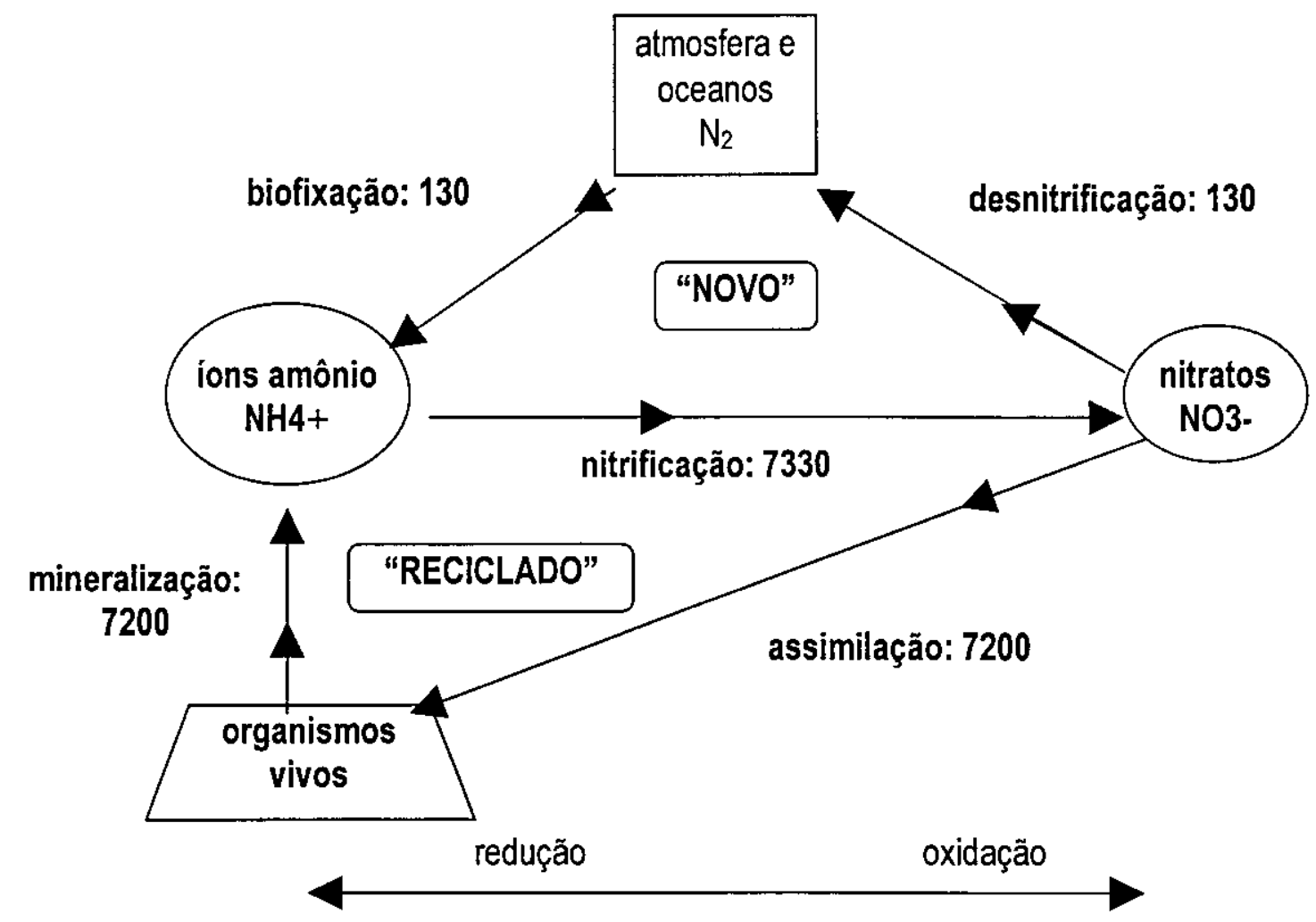

fonte: AYRES et al. (1994). 
Descrevendo superficialmente o ciclo do $\mathrm{N}$-reciclado, que pode ser definido como o ciclo terrestre do nitrogênio, encontramos quatro reservatórios principais - plantas, microorganismos do solo, matéria orgânica morta e nitrogênio inorgânico (amônia e nitrato). Os fluxos ocorrem entre o solo e as plantas. Aqui não existe a quebra da ligação do dinitrogênio e, portanto, não há acréscimo na quantidade de $\mathrm{N}$ no reservatório global. As plantas são responsáveis por $94 \%$ do nitrogênio existente nos organismos vivos (KINZIG \& SOCOLOW, 1994).

Os quatro processos principais que movimentam o nitrogênio dentro do ciclo terrestre são: - morte de plantas e microorganismos.

- mineralização ou liberação de nitrogênio como amônia pela ação de microorganismos que quebram a ligação entre um átomo de carbono e um grupo amino de um aminoácido.

- assimilação de nitrogênio inorgânico pelas plantas.

- imobilização de nitrogênio inorgânico por microorganismos.

Além destes fluxos dentro dos ecossistemas terrestres, existem os intercâmbios entre ecossistemas. As adições de nitrogênio (subciclo $\mathrm{N}$-novo) incluem a fixação biológica e a industrial (antropogênica), onde ambas disponibilizam compostos de nitrogênio da atmosfera para os ecossitemas terrestres.

O escorrimento superficial e os lençóis freáticos deslocam o nutriente de um ecossistema para outro e junto com a desnitrificação, a volatilização de amônia, a lixiviação e a colheita de material vegetal, são fluxos responsáveis pela perda de nitrogênio de um sistema.

Muitos ecossitemas apresentam um ciclo "fechado" do nitrogênio na perspectiva de que as taxas de adição ou perda são muito pequenas quando comparadas às taxas internas de ciclagem. Em outras palavras, o fluxo do subcilo $\mathrm{N}$-reciclado é muito mais intenso que o fluxo do subciclo $\mathrm{N}$ novo (no periodo pré-industrial, $92 \%$ do nitrogênio na terra era reciclado, AYRES et al., 1994).

Ecossitemas intocados e em equilibrio estão associados à perdas reduzidas de nitrogênio para os lençóis freáticos ou para a atmosfera, porque existe um relativo equilibrio entre o fornecimento e a demanda do nutriente por plantas e microorganismos (KINZIG \& SOCOLOW, 1994), e também porque a habilidade destes de absorver rapidamente o nitrogênio disponível pode, por exemplo, reduzir a quantidade que poderia ser perdida através de desnitrificação ou lixiviação.

Agroecossistemas ou ecossistemas naturais desequilibrados, por outro lado, apresentam frequentemente ciclos "abertos" de nitrogênio com adições e perdas de intensidade semelhante ou maior do que as taxas internas de ciclagem (KINZIG \& SOCOLOW, 1994). 


\subsubsection{Perturbações Provocadas pela Atividade Humana}

A atividade humana vem modificando o ciclo do nitrogênio em todos os aspectos (figura 2.2). A modificação considerada mais séria é a quantidade de nitrogênio fixada, que dobrou nos a partir da década de 60 em relação ao periodo pré-industrial (STEWART et al., 1992; HONTI, 1981).

Figura 2.2 Ciclo do nitrogênio no período atual (milhões de toneladas por ano).

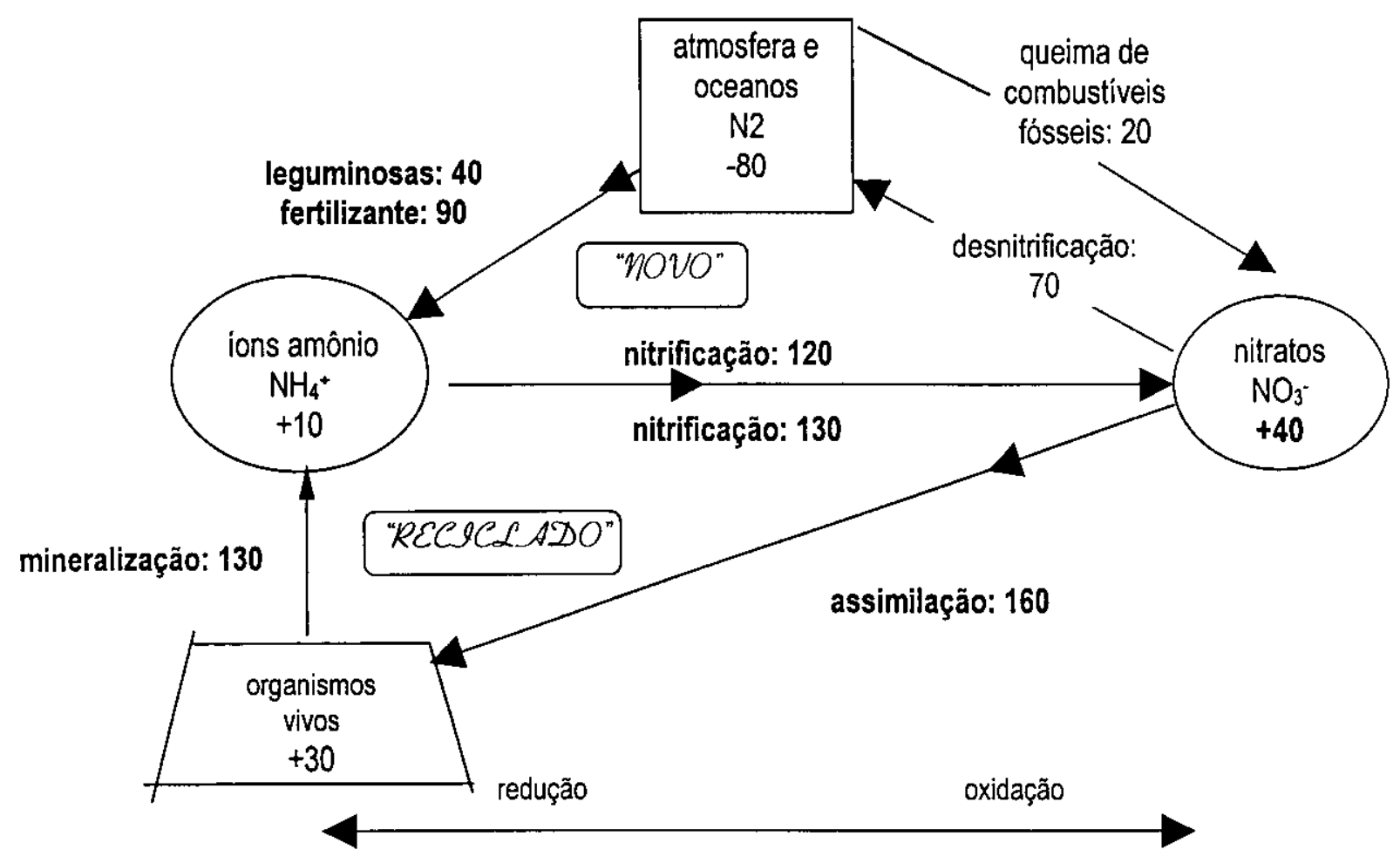

fonte: AYRES et al. (1994).

A produção de fertilizantes minerais nitrogenados (FMN) é apontada como a maior responsável por esta fixação extra de nitrogênio. Estima-se que a contribuição seja da ordem de 90 milhões de tN/ano e que é um fenômeno novo, iniciado a partir de 1960 , quando a produção mundial passou de 10 milhões para os 90 milhões tN/ano (SMIL, 1990). O processo de transformação da agricultura denominado "Revolução Verde" é apontado como a causa deste rápido aumento na demanda de FMN porque seu objetivo principal era aumentar a produtividade das culturas e o nitrogênio, por ser um dos nutrientes limitantes, ser responsável pelo crescimento 
vegetativo das culturas, além de ser componente da molécula de clorofila; quando fornecidó corretamente, produz efeitos rápidos significativos no desenvolvimento das culturas.

A produção de FMN também interfere no ciclo do carbono, pois não existe outra indústria conectada em todos os aspectos com energia ${ }^{1}$ como é a indústria do nitrogênio já que esta utiliza combustiveis fósseis como matéria-prima e, através da combustão no processo produtivo, emite entre outros, o dióxido de carbono à atmosfera.

Além da indústria de fertilizantes nitrogenados, outros fatores antropogênicos são apontados como ruptores do equilibrio do ciclo do nitrogênio. Alguns deles estão influindo conjuntamente no ciclo do carbono como será descrito a seguir.

O aumento da área cultivada com leguminosas - cerca de 250 milhões de hectares - é apontado como responsável por uma fixação "extra" de 35 milhões de tN/ano. Todas as culturas estariam fixando anualmente 40 milhões de tN/ano a mais (AYRES et al., 1994).

O manejo incorreto do solo nas práticas agricolas, junto com o aumento da quantidade de nitrogênio fixada contribuem indiretamente para elevar a concentração de ions de nitrogênio em rios, lagos e nos lençóis freáticos.

A erosão que carrega a camada superficial do solo, carrega também nitrogênio. A quantidade de nitrogênio aplicada na forma de FMN aumenta ainda mais o volume de nitrogênio levado com os solos. A estimativa é que o fluxo de $\mathrm{N}$ da terra para o mar atualmente seja de 40 milhões de tN/ano (AYRES et al.,1994) em consequência do escorrimento superficial, correspondendo ao dobro da quantidade que fluia por este processo no periodo pré-industrial.

A quantidade de nutrientes fornecida na forma de fertilizantes não é homogênea em todas as regiões do planeta em consequência de caracteristicas ambientais e econômicas. A diferença é mais acentuada quando são comparados os paises desenvolvidos com os países em desenvolvimento. Por isto a eutrofização das águas e dos solos também não ocorre na mesma intensidade. Sabe-se que os principais problemas de contaminação por nitrogênio aparecem em paises da Europa e nos Estados Unidos porque estes paises quando comparados ao Brasil, por exemplo, aplicam, por unidade de área, uma quantidade muito maior de fertilizantes.

A quantidade de amônia volatilizada também aumentou nos últimos anos. A principal fonte de aumento da volatilização é o aumento do rebanho bovino, estimado em 1,3 bilhões de cabeças atualmente. Sabendo que, em média eles excretam $16 \mathrm{~kg} \mathrm{~N}$ na forma de amônia por ano, isto

\footnotetext{
1 A geração de energia é considerada a principal emissora dos gases causadores do efeito estufa.
} 
resulta em 20 milhões $\mathrm{tN}$ na atmosfera (AYRES et al., 1994). O Brasil possui o segundo maior rebanho bovino do mundo, com 160 milhões de cabeças, o que o faz responsável por $12 \%$ do total de nitrogênio emitido por esta fonte.

A estimativa de adição de $\mathrm{N}$ por volatilização por todas as fontes é de 75 milhões de tN/ano onde:

- 12 milhões são provenientes da excreta de outros rebanhos que não o bovino.

- 10 milhões de processos biológicos em ecossistemas intactos.

- 9 milhões de processos biológicos em solos fertilizados.

- 13 milhões de processos na superficie dos oceanos.

-11 milhões de outras atividades.

O aumento da quantidade de amônia volatilizada é um dos fatores que está relacionado aos ciclos do nitrogênio e carbono, pois o nitrogênio é ingerido na forma de vegetais, depois excretado principalmente na forma de uréia, esta é decomposta, tal como ocorre na aplicação de uréia fertilizante, resultando em amônia e dióxido de carbono. O ciclo do carbono è também afetado pela emissão de dióxido de carbono na decomposição da uréia e metano por ação bacteriana nos estômagos e intestinos dos animais.

A amônia não se acumula na atmosfera, pois é extremamente solúvel e reativa. $O$ ion amônio volta para a terra quando a amônia combina com gotas d'água que contém ácido nitrico ou ácido sulfúrico, formando nitrato de amônio ou sulfato de amônio. Estes são sais solúveis rapidamente levados da atmosfera pela chuva.

A queima de combustiveis fósseis mobiliza cerca de 20 milhões $t N / a n o$ pela injeção na atmosfera de óxidos de nitrogênio. A taxa de mobilização de $\mathrm{N}$ por combustão, entretanto, é cinco vezes menor que a taxa associada à produção de FMN. Em contrapartida, é a atividade humana considerada a principal emissora do gás causador do efeito estufa: $\mathrm{CO}_{2}$.

Dados revelam que duzentos anos atrás, a concentração de $\mathrm{N}_{2} \mathrm{O}$ era relativamente constante, ao redor de $285 \mathrm{ppbv}$, o que equivale a um reservatório de 1.400 milhões de toneladas de nitrogênio na forma de óxido nitroso na atmosfera (OECD/IEA, 1991). Óxido nitroso entra na atmosfera como um minoritário subproduto da nitrificação e desnitrificação e o único fluxo conhecido que o remove ocorre na estratosfera, pela atuação dos fótons solares ultravioleta ou por oxigênio atomicamente ativo, produzindo tanto $\mathrm{N}_{2}$ quanto NO. A taxa de destruição destes dois 
mecanismos é uma em 150 moléculas de $\mathrm{N}_{2} \mathrm{O}$ por ano - o que equivale a dizer que seu tempo de residência na atmosfera é de 150 anos.

Estes mecanismos não sofreram modificações desde os tempos pré-industriais, o que permite estimar a taxa de transferência de $\mathrm{N}_{2} \mathrm{O}$ dentro e fora da atmosfera: esta é igual ao tamanho do reservatório de $\mathrm{N}_{2} \mathrm{O}$ atmosférico dividido pelo tempo de residência, ou seja, 10 milhões de toneladas de nitrogênio por ano. Nos dias atuais, constatou-se que a concentração desta molécula na atmosfera está se elevando a uma taxa de 1 ppbv/ano, atingindo 310 ppbv, o que significa 5 milhões tN/ano adicionais (SEPA, 1991).

Finalmente, estas evidências indicam que está ocorrendo um acréscimo do nitrogênio biodisponivel na terra quando se compara como a atividade humana vem afetando:

- a taxa de mobilização do $\mathrm{N}_{2}$ da atmosfera (fixação).

- a taxa de retorno do $N_{2}$ para a atmosfera (desnitrificação).

Já foi estimado o aumento antropogênico da fixação global de $\mathrm{N}$ como sendo de 150 milhões tN/ano (aumento da produção de fertilizantes, elevação da área plantada com leguminosas, queima de combustiveis fósseis).

A desnitrificação ocorre nas áreas de vegetação nativa e nas áreas cultivadas - na decomposição do material vegetal e nas reações que ocorrem com os fertilizantes aplicados (TURNER et al., 1990). Para estimar a taxa de desnitrificação, AYRES et al. (1994) indicam o aumento da emissão de $\mathrm{N}_{2} \mathrm{O}$ para a atmosfera em 5 milhões tN/ano como o fator que possibilita verificar se todo o nitrogênio extra que está sendo fixado está retornando à atmosfera.

Assumindo-se que este incremento se deve exclusivamente à desnitrificação e que existe uma relação definida entre as taxas de emissão de $\mathrm{N}_{2}$ e $\mathrm{N}_{2} \mathrm{O}$, nota-se que haverá um crescimento de $\mathrm{N}$ na flora a menos que a razão $\mathrm{N}_{2} / \mathrm{N}_{2} \mathrm{O}$ na desnitrificação seja maior que 30 . Esta relação, porém, não é muito conhecida, mas provavelmente seja menor que 30. $\mathrm{O}$ "Council for Agriculture Science and Technology" (1976) citado por AYRES et al. (1994) determinou esta relação como sendo 16, o que determina que a ação antropogênica está provocando uma elevação na quantidade de nitrogênio disponivel na biota.

$\mathrm{O}$ argumento para este acréscimo líquido é ainda mais forte quando se considera que nem todo aumento nas emissões de $\mathrm{N}_{2} \mathrm{O}$ na atmosfera é consequência da desnitrificação. Outras fontes possíveis de emissão são: nitrificação, emissões diretas da atividade industrial para a produção de 
nyion, explosivos e fertilizantes, combustão de hidrocarbonetos e queima de biomassa (BOLLE, 1986).

Embora os detalhes quantitativos sejam incertos, as estimativas numéricas de estoques e fluxos estão concernentes a balanços de massa e a razões entre os elementos, como a relação $\mathrm{C} / \mathrm{N}$ e a razão molecular $\mathrm{N}_{2} / \mathrm{N}_{2} \mathrm{O}$, permitindo assumir que:

- o aumento da desnitrificação anual é equivalente a 70 milhões $\mathrm{tN}$.

- o aumento resultante do $\mathrm{N}$ na biota é de 80 milhões $\mathrm{t} N$, ocorrendo apenas na terra.

- este aumento anual é dividido em: 30 milhões $\mathrm{tN}$ nas plantas, 40 milhões $\mathrm{tN}$ em nitratos e 10 milhões em aminas.

AYRES et al. (1994) indicam que a mineralização incremental é equivalente a 130 milhöes tN/ano - assumindo que a reciclagem do incremento de $\mathrm{N}$ provocado pela atividade humana estabeleceu-se apenas na extensão de que na terra, os fluxos para o reservatório de $\mathrm{N}$-reduzido bio-disponivel provenientes do subciclo $\mathrm{N}$-novo e do subciclo $\mathrm{N}$-reciclado são iguais. Sabendo-se que no ciclo do $\mathrm{N}$ na terra no periodo pré-industrial, a mineralização excedia a fixação (biológica) de $\mathrm{N}$ na proporção de 12:1, é aceitável então, que o tempo requerido para estabelecer tão eficiente reciclagem possa exceder substancialmente o tempo em que se iniciaram os distúrbios humanos aos ciclos dos nutrientes (AYRES et al., 1994).

\subsubsection{A Situação do Brasil}

No Brasil, o fornecimento de nitrogênio e outros nutrientes para a agricultura é deficiente e heterogêneo entre as culturas (gráficos 2.1 e 2.2). Além disso, a aplicação incorreta do fertilizante mineral nitrogenado gera perdas do insumo por volatilização e lixiviação. Tais características provocam um grande desequilíbrio, pois existe uma retirada de nutriente pelas culturas e esta não está sendo compensada. 
Gráfico 2.1. Necessidade e consumo total de nitrogênio para algumas culturas - Brasil, 1992.

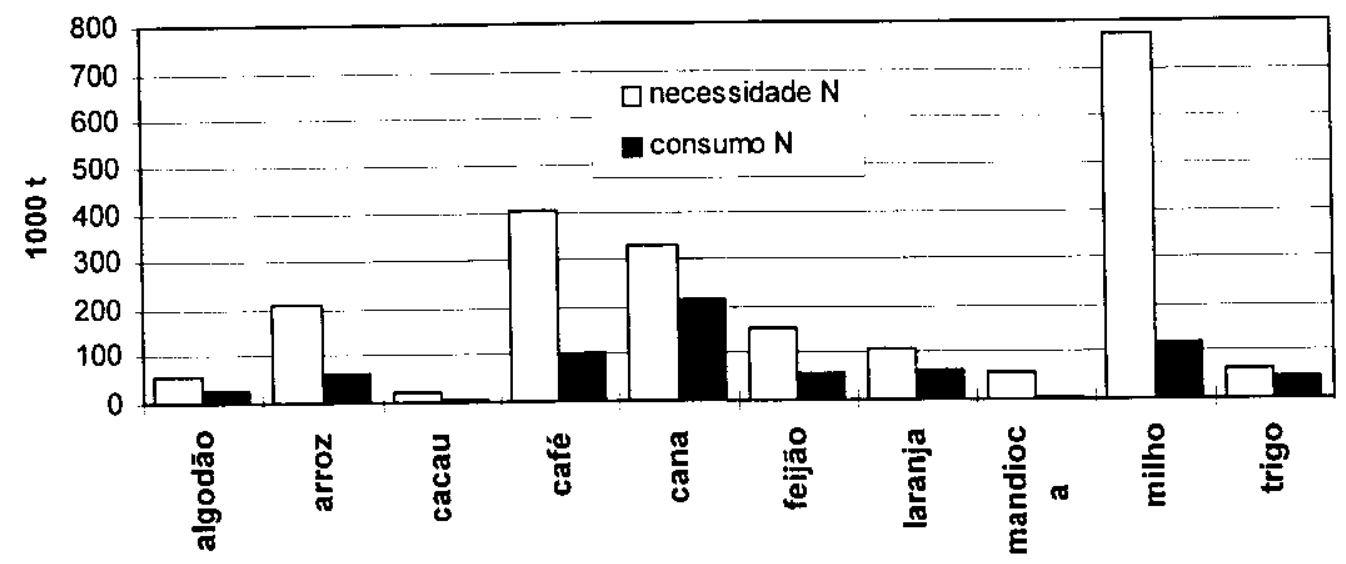

fonte: MALAVOLTA (1992).

Gráfico 2.2. Nutrientes fornecidos por adubação e retirados do solo pelas colheitas - Brasil, 1994.

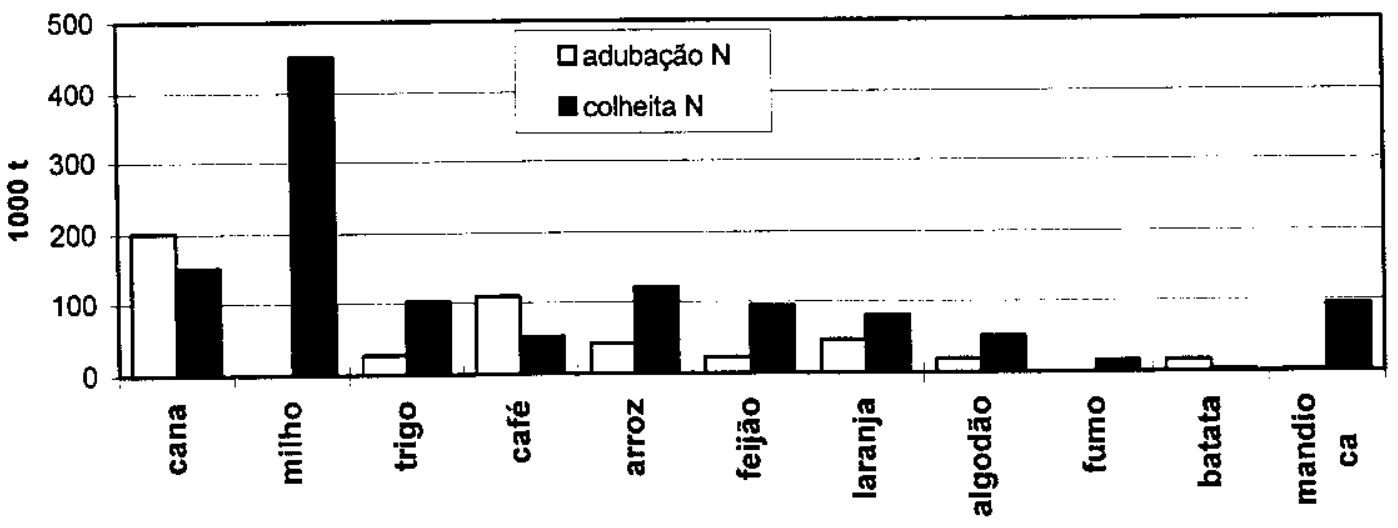

fonte: RAIJ (1994).

Pode-se dizer que o consumo deficiente de nitrogênio seja um dos fatores que determinam o baixo desempenho da agricultura brasileira. É claro que fatores sociais, políticos e econômicos como a estrutura fundiária, politica agricola favorecendo produtos de exportação e concorrência internacional com produtos agricolas subsidiados também desfavorecem o desenvolvimento da agricultura brasileira, porém, o enfoque deste estudo não permite uma avaliação de todos estes itens. 
Para LOPES (1994), não se pode estranhar que nossa produtividade média de grãos em relação a outros paises e aos produtores considerados tecnificados (tabela 2.1), ainda apresente amplos espaços para ganhos imediatos nas culturas produtoras de alimentos básicos. $O$ autor não defende que a agricultura brasileira alcance o "super consumo" da Holanda, mas alega que nosso consumo médio anual de $67 \mathrm{~kg} / \mathrm{ha}$ de nutrientes não é compativel com as necessidades do solo, clima e culturas aqui plantadas. Aponta para a necessidade da adoção de medidas que propiciem o uso de quantidades adequadas de nutrientes como instrumento do aumento da produtividade da agropecuária brasileira, com a finalidade de diminuir as pressões de desmatamento e exploração de áreas poucos vocacionadas à exploração agricola.

Tabela 2.1. Média brasileira de produtividade e média atingida por agricultores tecnificados.

\begin{tabular}{cccccc}
\hline cultura & unidade & média & agricultores & \multicolumn{2}{c}{ diferença } \\
& & brasileira & tecnificados & 2500 & equiv.ha \\
algodão & $\mathrm{kg} / \mathrm{ha}$ & 1200 & 3700 & 5900 & 2,1 \\
arroz & $\mathrm{kg} / \mathrm{ha}$ & 2100 & 8000 & 900 & 2,8 \\
cacau & $\mathrm{kg} / \mathrm{ha}$ & 600 & 1500 & 20 & 2,5 \\
café & $\mathrm{sacas} / \mathrm{ha}$ & 10 & 30 & 32 & 0,5 \\
cana & tha & 63 & 95 & 1950 & 4,3 \\
feijão & $\mathrm{kg} / \mathrm{ha}$ & 450 & 2400 & 988 & 2,4 \\
laranja & caixas/ha & 409 & 1397 & - & - \\
mandioca & tha & 12 & - & 6000 & 3,4 \\
milho & $\mathrm{kg} / \mathrm{ha}$ & 2000 & 8000 & 1100 & 0,6 \\
soja & $\mathrm{kg} / \mathrm{ha}$ & 1900 & 3000 & - & - \\
trigo & $\mathrm{kg} / \mathrm{ha}$ & 1600 & - & & \\
\hline
\end{tabular}

fonte: MALAVOLTA (1992).

Outros autores também afirmam que existe uma deficiência de fornecimento de nitrogênio na agricultura brasileira, como Bemardo van RAIJ, 1994:

"... há espaço para o crescimento isolado do consumo de nitrogênio, o que poderá levar a aumentos expressivos para a produtividade de algumas culturas, com destaque para milho e outros cereais."

Além dele, Alfredo Scheid LOPES (1994) afirma:

"A mensagem é bastante clara. De alguma forma, seja através da rotação de culturas, adubação verde, adubação orgânica, adubação mineral, manejo adequado dos restos culturais, cultivo minimo, plantio direto, etc., é necessário introduzir mais nitrogênio no sistema, em relação ao consumo atual de fósforo e potássio, e inclusive manejá-lo de forma eficiente para minimizar perdas por lixiviação. $O$ beneficio final seria, inclusive, 
maior produção de massa verde e maior produção de matéria orgânica com todos os beneficios que isto representa."

\subsubsection{Cónsequências do Aumento da Fixação de Nitrogênio}

Mesmo com todas estas evidências, não é possivvel ainda, avaliar o significado acurado dos efeitos dos distúrbios no ciclo do nitrogênio para os seres humanos - tanto em termos absolutos como relativos ao distúrbio do ciclo do carbono.

Pode-se dizer que os ecossistemas locais estão sendo afetados de duas maneiras por causa do aumento da quantidade de nitrogênio fixado: mudanças no balanço de nutrientes e mudanças na acidez do meio ambiente (SCHNOOR \& THOMAS, 1992).

Nitrogênio é um fator limitante em muitos ecossistemas, então um aumento de $\mathrm{N}$ fixado geralmente eleva a produtividade primária. Infelizmente, em ecossistemas naturais, elevação da produtividade primária significa ruptura, porque haverá um crescimento irregular de algumas espécies em relação a outras (SCHLESINGER, 1994).

Uma elevação da quantidade de nitrogênio não significa necessariamente aumento da acidez local. Em lugares onde há aumento da concentração de formas reduzidas do elemento, 0 ambiente torna-se menos ácido, enquanto em locais de elevação da concentração de formas oxidadas, o ambiente torna-se mais ácido. Ambas as modificações são pertubadoras do equilíbrio. Globalmente, o efeito total é o aumento da acidez, porque o nitrogênio é uma base fraca quando na forma reduzida, mas um ácido forte quando na forma oxidada (SCHLESINGER, 1994).

A elevação da acidez dos ecossistemas, como lagos, provoca sua degradação por causa da mobilização do alumínio e outros íons metálicos que anteriormente estavam ligados firmemente à partículas de solo, matando anfíbios e peixes por contaminação.

O aumento excessivo da acidez do solo pela deposição de ácido nítrico tende a exceder a capacidade do solo de manter a alcalinidade (na forma de ions de cálcio e magnésio), aumentando a concentração de hidrogênio e disponibilizando consequentemente, um excesso de nutrientes que as plantas não podem absorver - o resultado é a perda destes cátions através da lixiviação (KINZIG \& SOCOLOW, 1994). 
O óxido nitroso contribui imensamente para o efeito estufa, é centenas de vezes mais poderoso do que o dióxido de carbono - seu Poder de Aquecimento Global 2 é 270 . Estima-se que a emissão de $\mathrm{N}_{2} \mathrm{O}$ aumentou em $50 \%$ quando comparada ao período pré-industrial e, por isso, muito esforço tem sido feito para conhecer o ciclo global deste gás. Para KINZIG \& SOCOLOW (1994), a elevação de sua concentração na atmosfera nos dias de hoje está contribuindo em $5 \%$ para a retenção extra da radiação infravermelha.

Ao mesmo tempo, a fertilização nitrogenada pode estar diminuindo a intensidade do efeito estufa transferindo carbono da atmosfera para a biosfera, pois esta pode estar aumentando a taxa de carbono "sequestrada"3 pelas plantas e solos, porque tanto o carbono quanto o nitrogênio são requeridos para a sintese de material biológico e ambos são liberados na sua decomposição (KINZIG \& SOCOLOW, 1994).

Pode-se afirmar, portanto, que o desequilíbrio do ciclo do carbono está levando provavelmente ao aquecimento global, e o desequilibrio do cicio do nitrogênio, provavelmente está levando a uma fertilização global (AYRES et al., 1994).

\subsection{A preocupação com o Meio Ambiente associada ao Desenvolvimento Sustentável}

... a produção de alimentos e de energia afetam o estado do ambiente e por ele são afetadas. Os padrões de uso de energia, de terra e de água terão influência cada vez maior nos climas, com consequência de longo alcance nos eco e agroecossistemas." SACHS (1986).

Embora a humanidade esteja passando por um período de transição, onde os assuntos em pauta sejam a mudança nos niveis de consumo, emprego de tecnologias "limpas" em todos os

\footnotetext{
2 Poder de Aquecimento Global, por peso molecular e um horizonte temporal de 20 anos. Em inglês Global Warming Potential, indicador para mostrar o potencial de contribuição dos gases ao aquecimento global, dependente do tempo que estes permanecem na atmosfera e de sua concentração.

${ }^{3} \mathrm{~A}$ magnitude do aumento do estoque de carbono por causa da fertilização nitrogenada é dependente da relação $\mathrm{C}: \mathrm{N}$ dos reservatórios.
}

${ }^{4}$ Tecnologias que não provoquem ou reduzam os impactos negativos ao meio ambiente como emissão de gases causadores do efeito estufa, efluentes tóxicos. 
setores da economia, estímulo à utilização de recursos renováveis; os paises em desenvolvimento têm uma prioridade acima de todas essas questões: a erradicação da pobreza.

Para a minimização da pobreza é necessário que se propicie o acesso à educação, saúde, alimentos e energia na forma de serviços a todas estas pessoas que ainda não tiveram oportunidade de usufruir destes direitos.

Chega-se ao "gargalo" da questão: para atender a estes requisitos básicos do desenvolvimento, o nivel de consumo de recursos tem de se elevar. Com esta elevação no consumo, aumentam também o nivel de emissões de gases do efeito estufa, a eutrofização das águas, a quantidade de resíduos, a erosão do solo e todos os outros fatores negativos que caminham em conjunto com o que é oferecido hoje para elevar o "bem estar social", "qualidade de vida" e a "segurança alimentar".

O que se discute são exatamente os meios de se trilhar o desenvolvimento dessas nações diante das restrições que surgiram em relação ao padrão atual de utilização de recursos naturais e energia. O exemplo concreto dessas demandas e sua respectiva "oferta", digamos assim, foi a Conferência das Nações Unidas Sobre Meio Ambiente e Desenvolvimento em 1992, resultando em um documento, a Agenda 21, que está sendo colocada como a linha mestra a ser seguida pelas nações rumo ao que tem se denominado desenvolvimento sustentável. 0 documento salienta a importância de se mudar os padrões de consumo dos recursos naturais através do seu uso eficiente para reduzir ao mínimo a velocidade de seu esgotamento e a poluição.

Observa-se entretanto que, para que haja mudança nos padrões de consumo, é necessário incentivar os produtores e consumidores através de estímulos de mercado e da inclusão dos custos ambientais do consumo de energia, matérias-primas, recursos naturais e da geração de resíduos.

A redução do volume de energia e dos materiais utilizados por unidade na produção de bens e serviços pode contribuir simultaneamente para a mitigação da pressão ambiental e 0 aumento da produtividade e competitividade econômica e industrial. $\mathrm{O}$ objetivo é estimular 0 desenvolvimento industrial por meio de formas que minimizem os impactos adversos sobre a atmosfera aumentando a eficiência na produção e no consumo de todos os recursos e matériasprimas, aperfeiçoando as tecnologias de redução de poluição e desenvolvendo novas tecnologias ambientalmente saudáveis.

No que se refere a agricultura, a Agenda 21 (1992) ressalta que: 
“... é preciso dar prioridade à manutenção e aperfeiçoamento da capacidade das terras agricolas de maior potencial. No entanto a conservação e a reabilitação dos recursos naturais das terras com menor potencial, com o objetivo de manter uma razão homem/terra sustentável, também são necessárias."

A FAO e o INCRA, em um relatório conjunto de 1994, registraram também:

" ...cresce a consciência sobre as distorções ambientais dos atuais sistemas de produção e de consumo de alimentos. Uma ampla gama de manifestações sociais permite perceber uma crescente preocupação com a salubridade alimentar, que tende a estar cada vez mais ligada à preservação dos recursos naturais usados em sua produção. $E$ as pressões decorrentes já requerem novos métodos de produção agropecuária que venham a reduzir os impactos ambientais adversos e assegurar attos niveis de pureza e não toxidade aos alimentos. É este, em última instância, o desafio social embutido na expressão agricultura sustentável".

As tecnologias que propiciam um manejo agrícola integrado são consideradas elementos incentivadores na transformação para sistemas agricolas sustentáveis:

“...por exemplo rotação de culturas, adubação orgânica e outras técnicas que signifiquem redução do uso de produtos agroquímicos, bem como inúmeras técnicas voltadas para a exploração de fontes de nutrientes e a utilização eficiente dos insumos externos..." (AGENDA 21, 1992).

Coloca-se que os países em desenvolvimento devem incorporar as possibilidades tecnológicas mais eficientes ao seu processo de desenvolvimento através do "pulo do sapo" (GOLDEMBERG, 1996) $)^{5}$, isto é, não é necessário seguir o patamar tradicional de desenvolvimento e somente depois remediar a situação.

As políticas públicas e a educação são colocadas como importantes instrumentos na tarefa de se construir este novo padrão de desenvolvimento, onde a exigência por novas alternativas aparece em todas as áreas do conhecimento e da economia.

Levando-se em conta as afirmações a respeito dos distúrbios provocados pelo homem no ciclo do nitrogênio, investigar meios de se minimizar as relações negativas na produção e utilização de fontes de nitrogênio na agricultura é um assunto inserido nas exigências de transformação necessárias para se alcançar o desenvolvimento sustentável.

${ }^{5}$ notas de aula, disciplina: Energia, Meio Ambiente e Desenvolvimento, ENE-718 - PIPGE/USP. 


\subsubsection{A Relacão entre Agricultura e Energia}

"...energia $e$ alimentos são dois itens cuja disponibilidade regular e contínua são condição sine qua non para a sobrevivência humana, levantando um desafio enorme, que terá de ser atacado simultaneamente do lado da demanda e da oferta." SACHS (1986).

O nitrogênio é um nutriente essencial para as culturas, sendo que a fonte mais utilizada no Brasil e no mundo é o fertilizante mineral.

Entretanto, a indústria produtora deste insumo é considerada energo intensiva, por empregar combustiveis fósseis como matéria-prima e combustivel, e pela necessidade de altas pressões e temperaturas durante o processo produtivo. A emissão de gases causadores do efeito estufa, o consumo de recursos naturais não renováveis e 0 aumento da taxa de fixação de nitrogênio estabelece uma relação direta deste setor industrial e seus consumidores, com 0 compromisso de alcançar padrões produtivos que reduzam estes impactos negativos ao meio ambiente.

O mercado já oferece tecnologias que reduzem o consumo de energia para a produção de FMN, resultando em um produto final de menor valor energético, e em um nível menor de emissão de efluentes. Mesmo porque, a viabilidade econômica da produção depende desta eficiência na medida em que a matéria-prima representa parte substancial dos custos de produção.

$\mathrm{Na}$ agricultura, o uso de fertilizantes minerais está inserido no modo de produção intensiva pregado pela "Revolução Verde". FANCELLI (1994) esclarece que este processo de inovação foi representado pela modificação genética de diversas espécies cultivadas aumentando sua capacidade produtiva. Todavia, tal inovação resultou na dependência da disponibilidade de fatores de produção e técnicas diversas, de natureza qualitativa e quantitativa. Tal advento tecnológico moldou-se, não fugindo à regra, de acordo com o sistema agrícola capitalista norte-americano, que consome, no cultivo e processamento de alimento, 20,5\% de toda energia utilizada nos EUA.

A "Revolução Verde", segundo SACHS (1986), pelo menos em sua fase inicial, inspirou-se numa filosofia de desenvolvimento universalista e difusionista, que atribuiu demasiado crédito às virtudes da transferência de técnicas e à generalização de certas variedades "milagrosas" de trigo e arroz. Esta visão reducionista do agroecossistema, porém, não mais resulta em bons indices, 
principalmente nas áreas tropicais e sub-tropicais do planeta. Alguns fatores são apontados como causa desta situação:

- a degradação do solo provocada pela erosão - que leva, além de particulas do solo, nutrientes - e pela falta de cobertura vegetal está levando a uma redução da matéria orgânica e consequente perda de fertilidade deste fator indispensável à atividade agricola.

- a diminuição da diversidade biológica nos sistemas de produção agricola provocada pela introdução dos monocultivos passou a demandar quantidades cada vez mais altas de defensivos agricolas (pesticidas, herbicidas e fungicidas), contribuindo para a contaminação do agricultor, do solo e das águas.

KUETHER e DUFF apud HOBBELINK (1990) chegaram à conclusão de que:

“...̀̀ medida em que se moderniza o sistema de produção de alimentos, aumenta-se 0 consumo de energia. Além de se perder a eficiência energética, cresce a dependência às suas formas comerciais de formecimento, tomando os sistemas mais sensiveis, sujeitos a flutuações de preços dos agro-insumos comprados"

Este modo de produção trouxe, também, a eliminação de práticas e conhecimentos tradicionais adquiridas pelos agricultores. Com isso, no caso das fontes de nitrogênio, outras alternativas de fornecimento através de compostos orgânicos ou adubação verde foram deixadas de lado.

\subsubsection{Diretrizes para Reduzir os Distúrbios no Ciclo do Nitrogênio}

Apesar de existir um desequilibrio em ambos os grandes ciclos: do nitrogênio e do carbono, somente o ciclo do carbono vem recebendo grande atenção no periodo atual, em função da relação do aumento da concentração de dióxido de carbono e seu potencial de provocar o aquecimento do planeta.

AYRES et al. (1994) consideram que o desinteresse pela ruptura no ciclo global do nitrogênio pode ser explicado pelo tipo de mudanças que provoca: modificações no balanço de nutrientes (logo, nos ecossistemas) ao invés de modificações no nivel do mar e padrões de precipitação pluviométrica. Os autores consideram que è mais fácil "simpatizar" com mudanças climáticas do que com desbalanço de nutrientes, mas as consequências para a humanidade podem ser severas em ambos os casos. 
Uma das fontes de distúrbio no ciclo do $\mathrm{N}$ já tem recebido atenção nas políticas públicas - $\mathrm{a}$ formação de $\mathrm{NO}_{x}$ pela queima de combustiveis fósseis por serem gases que provocam a chuva ácida.

Erosão dos solos, uma segunda fonte de ruptura através da sua conexão com o nitrogênio carregado pelo escorrimento superficial, tem sido elemento constante nas politicas agricolas através do estimulo à adoção de estratégias para seu combate.

Entretanto, politicas dirigidas para a produção e uso de FMN - o fator mais importante de desequilibrio no ciclo do $\mathrm{N}$ - que resultariam numa elevação da eficiência de fixação do nitrogênio estão muito menos desenvolvidas.

Para KINZIG \& SOCOLOW (1994) as estratégias para reduzir os impactos humanos no ciclo do carbono devem ser tomadas como exemplo para estabelecer estratégias de modificações no ciclo do nitrogênio porque as primeiras já têm sido objeto de pesquisa há algumas décadas.

Alguns exemplos de possiveis inovações são mencionados por KINZIG \& SOCOLOW (1994):

- incentivar a combinação de culturas e melhorar o manejo do solo para elevar a produtividade a um mesmo nivel de utilização de fertilizantes.

- melhorar mecanismos e estratégias para reter o nitrogênio natural e sintético no sistema do solo para depois disponibilizá-lo às plantas.

- utilizar a biotecnologia para produzir culturas modificadas tais como o milho capaz de fixar nitrogênio.

Além disso, muito pode ser conseguido através de conhecidas e importantes práticas de manejo, como por exemplo, o uso de leguminosas em um sistema de rotação com as culturas comerciais que faz com que a disponibilidade de nitrogênio e o conteúdo de matéria orgânica do solo se elevem. A altemância entre culturas com comprimento de raizes diferentes (as leguminosas possuem sistema radicular profundo) pode reduzir as perdas de nitrogênio porque as raizes mais profundas são capazes de assimilar o nutriente que foi levado às camadas mais profundas do solo por lixiviação e posteriormente retomá-lo à superficie através da decomposição do material vegetal. 


\section{INDÚSTRIA DE FERTILIZANTES NITROGENADOS}

\subsection{Consideracões Gerais Sobre a Indústria de Fertilizantes Nitrogenados}

A produção de fertilizantes pode ser dividida em quatro etapas: matérias-primas, produtos intermediários, fertilizantes simples e fertilizantes compostos. Praticamente toda a indústria se baseia no processamento de recursos naturais, como hidrocarbonetos (gás natural e derivados de petróleo) ou rochas com teores variáveis de fósforo ou potássio, além de enxofre, utilizado na produção de ácido sulfúrico. Entre os produtos intermediários, que constituem os insumos para a etapa seguinte, os principais são a amônia, o ácido sulfúrico, os concentrados fosfáticos e o ácido fosfórico (CALMANOVICl et al., 1989).

O processo atual de produção de FMN é baseado, principalmente, na utilização da amônia como insumo base. Aproximadamente $85 \%$ da produção mundial de amônia é utilizada para a fabricação de fertilizantes, o que a transforma em um insumo de extrema importância na produção mundial de alimentos. De acordo com o WORLD ENERGY COUNCIL (1995), dentre os quatro produtos considerados energo-intensivos no conjunto dos quimicos, a quantidade ofertada de amônia no mundo é equivalente ao dobro da oferta do segundo produto, o etileno.

A relação da indústria de fertilizantes nitrogenados com energia não está só no fato da utilização de hidrocarbonetos fósseis como matéria-prima, mas pela característica das transformações químicas que comumente geram energia calorifica capaz de ser recuperada como subproduto, e também, pela sempre presente necessidade de altas pressões e temperaturas durante o processo.

O modelo industrial brasileiro de produção de fertilizantes nitrogenados foi baseado nos modelos implantados no exterior, notadamente em paises que dispunham de recursos naturais, ou seja, as matérias-primas necessárias para a produção de fertilizantes. Em 1958, a PETROBRÁS implantou a primeira unidade brasileira de síntese de amônia anidra com capacidade para 90,7 tddia, utilizando o gás de refinaria proveniente da Refinaria Presidente Bernardes, em Cubatão-SP, como matéria-prima. Esta unidade tinha a finalidade de produzir nitrato de amônio e nitrocálcio. 
Até o fim da década de 60 , a produção brasileira de fertilizantes nitrogenados era dominada pelo nitrocálcio e pelo sulfato de amônio, com capacidade de produção de 140000 tano e 277.00 tano, respectivamente. O início de 1970 é considerado o marco histórico da produção de fertilizantes nitrogenados no Brasil, quando foi implantada a ULTRAFÉRTIL, primeira grande planta de produção de amônia, com capacidade de 454 t/dia no município de Cubatão-SP. Esta unidade foi montada com a participação de capitais privados nacionais e um sócio estrangeiro. Entretanto, com a desistência deste sócio, a PETROBRÁS decidiu assumir esta parte para evitar a paralização do projeto (PETROBRÁS, 1980).

De acordo com CALMANOVICl et al. (1989), no período de 1974 a 1980, grandes investimentos públicos foram feitos para a ampliação da capacidade de produção de fertilizantes. Tal política foi traçada no primeiro Plano Nacional de Fertilizantes e Calcário Agricola em 1974, como conseqüência principalmente da conjuntura internacional - o choque do petróleo - que refletiu em um aumento dos preços destes insumos. $O$ resultado destes investimentos foi a criação de uma subsidiária da PETROBRÁS, a PETROFÉRTIL, em 1976, que tornou-se responsável pelo desenvolvimento da indústria brasileira de fertilizantes.

A partir 1993, a ULTRAFÉRTIL, que é composta pelas unidades em Piaçaguera - São Paulo e em Araucária-Paraná, foi privatizada em leilão de desestatização, tornando-se parte da holding FERTIFÓS. A PETROBRÁS, a partir desta data, detém apenas as unidades de CamaçariBahia e Laranjeiras-Sergipe.

Os principais fertilizantes nitrogenados produzidos no país são: água amônia, uréia, solução uram, nitrato de amônio, nitrocálcio e sulfato de amônio.

\subsection{Oferta de Fertilizantes Minerais Nitrogenados e Amônia}

\subsubsection{Características do Mercado}

A indústria mundial de fertilizantes é um segmento da indústria química-petroquímica, onde, dentre os maiores produtores mundiais encontram-se muitas das empresas químicas multinacionais.

Outra característica do setor é ser integrante do grupo das commodities, possuindo então, de acordo com RAPPEL e LOIOLA (1993), características tecnológicas e mercadológicas próprias: 
estrutura de produção complexa e tecnologicamente interdependente, grandes escalas de produção (citam por exemplo, escalas mínimas econômicas de 1100 t/dia para uréia e 1300 t/dia para amônia), alta intensidade de capital dos investimentos (por exemplo, aproximadamente US\$ 150 milhões para uma planta de 1500 t/dia de amônia), tecnologias maduras e importância estratégica do acesso à matéria-prima.

DIESEL (1996) afirma que o segmento produtor de matérias-primas, por ser tipicamente de alta densidade de capital, justifica a histórica presença do capital público e estrangeiro. Ressalta ainda que, no caso brasileiro, tais participações podem ser explicadas pela debilidade financeira do empresariado nacional, face ao porte de capital necessário à instalação e ampliação da capacidade produtiva, em especial, de matérias-primas básicas. Vale registrar que esta realidade ocorreu também internacionalmente.

Mais um fator inibidor da iniciativa privada è o baixo nivel de retorno inicial dos investimentos. As taxas de retorno, desde 1985 têm sido baixas em relação aos demais setores do complexo químico devido aos baixos preços dos produtos finais e altos custos das matérias-primas (RAPPEL e LOIOLA, 1993). Entretanto, a tendência é a alteração desta situação (altos custos das matérias-primas) com a liberalização econômica em curso.

A indústria de fertilizantes nitrogenados é classificada como energo intensiva, sendo a energia (matéria-prima na forma de hidrocarbonetos), parte significativa de seus custos de produção: 20 - 30\% do custo de produção de fertilizantes nitrogenados (WORREL \& BEER, 1995) e $70 \%$ do custo de produção de amônia (ZARDI \& ANTONINI, 1979). Outra estimativa, baseada nos conceitos mais modernos de produção de amônia, aponta especificamente o gás natural representando mais de $70 \%$ dos custos variáveis (cash cost) e $45 \%$ dos custos totais (NITROGEN, 1997).

A globalização da indústria de fertilizantes e o já citado padrão de investimento (alta intensidade de capital) são mencionados por RAPPEL e LOIOLA (1993) como características que tendem a fazer com que o mercado internacional destes insumos seja crescentemente dominado por poucas empresas de grande porte.

Até recentemente, a ex-União Soviética era a maior produtora de amônia, mas sua produção tem declinado desde o final da década de oitenta. Foram os países em desenvolvimento (particularmente na Ásia) que demostraram o maior crescimento na produção. A produção cresceu com um taxa equivalente a duas vezes a taxa de crescimento mundial, atingindo os $4 \%$ a.a. China 
e índia aparecem como produtores em ascensão, juntamente com paises que possuem grande oferta de gás natural (WORLD ENERGY CONCIL, 1995).

Com relação ao mercado, o inicio dos anos 90 é caracterizado como um período de aumento dos superávits nos balanços de oferta/demanda de diversos fertilizantes devido à queda no consumo na Europa Oriental (53\% entre 1990-1992). RAPPEL e LOIOLA (1993) indicam que as previsões para o restante da década são de redução dos superávits dos fosfatados e potássicos e de um equilibrio oferta/demanda dos nitrogenados.

Outra peculiaridade da indústria de fertilizantes com relação à conduta mercadológica é a questão da sazonalidade das entregas, que ocorre, no Brasil, no segundo semestre, em função das principais culturas demandantes do produto serem plantadas durante este período (FERREIRA e VEGRO, 1996). Aproximadamente $66 \%$ das entregas são realizadas neste período a cada ano, 0 que resulta em um fator altamente diferenciador da conduta das indústrias de fertilizantes em relação a outras indústrias, no que concerne às estratégias de produção, vendas e fixação de preços (DIESEL, 1996). É importante salientar que esta sazonalidade tem como consequência a ociosidade das indústrias, levando em conta que as exportações do setor não são significativas e que os custos na manutenção de estoques são elevados. A abertura comercial permitiu flexibilizar o mercado através de importações, levando os produtores a retardar ainda mais as aquisições do insumo para um periodo cada vez mais próximo do plantio (FERREIRA e VEGRO, 1996).

\subsubsection{Preços dos FMN e Amônia}

Atualmente, quando se comparam os custos de produção de amônia utilizando diferentes matérias-primas no processo de reforma com vapor, não existe chance de competitividade de outros hidrocarbonetos com 0 gás natural (tabela 3.1). Exceções existem para situações muito particulares, como por exemplo, a parceria com uma refinaria torna a oxidação parcial das frações pesadas do petróleo, economicamente justificável (caso da unidade de Araucária-PR). Existe também, uma relação entre competitividade e condições de acesso (preço e disponibilidade) ao gás natural. 
Tabela 3.1. Custos de produção de amônia com diferentes matérias-primas em 1996 no noroeste da Europa (1800 t amônia/dia - valores em US\$)

\begin{tabular}{l|r|r|r}
\multicolumn{1}{c|}{ matéria-prima/processo } & $\begin{array}{c}\text { gás natural } \\
\text { reforma com } \\
\text { vapor }\end{array}$ & $\begin{array}{c}\text { residuo asf. } \\
\text { oxidação parcial }\end{array}$ & $\begin{array}{c}\text { carvão } \\
\text { oxidação } \\
\text { parcial }\end{array}$ \\
\hline preço da matéria-prima $\$ /$ milhão Btu & 3,0 & 2,1 & 1,9 \\
\hline energia total consumida milhäo Btu/t & 27,0 & 36,0 & 45,5 \\
\hline custos de energia e matéria-prima $\$ / \mathrm{t} \mathrm{NH}_{3}$ & 81,0 & 75,6 & 86,5 \\
\hline outros custos variáveis $\$ / \mathrm{t} \mathrm{NH} \mathrm{NH}_{3}$ & 34,1 & 45,5 & 68,2 \\
\hline total custos variáveis $\$ \mathrm{t} \mathrm{NH}_{3}$ & 115,1 & 121,1 & 154,6 \\
\hline custos relativos a capital $\$ / \mathrm{t} \mathrm{NH}_{3}$ & 72,4 & 104,2 & 173,7 \\
\hline custos totais $\$ / \mathrm{t} \mathrm{NH}_{3}$ & 187,5 & 225,3 & 328,3 \\
\hline investimentos milhöes $\$$ & 250,0 & 360,0 & 600,0
\end{tabular}

fonte: NITROGEN (1997).

RAPPEL \& LOIOLA (1993) afirmam que, no Brasil, o preço do gás natural é fixado com base na equivalência energética, estabelecendo-se diferenciação entre usuários e, atualmente, 0 preço interno é superior ao de vários países (tabela 3.2). Para os autores, este diferencial de preços repercute negativamente sobre a estrutura de custos variáveis do segmento produtor de nitrogenados.

Tabela 3.2. Preço do gás natural.

\begin{tabular}{lc}
\hline \multicolumn{1}{c}{ países } & valor US\$/milhão BTU \\
\hline Chile (Punta Arenas) & 0,30 \\
Oriente Médio & 0,50 \\
EUA & \\
atual & 1,30 \\
média de 12 meses & 1,45 \\
Brasil & \\
matéria-prima & 1,70 \\
combustivel & 2,20 \\
\hline
\end{tabular}

fonte: RAPPEL \& LOIOLA (1993).

Em 1994, entretanto, de acordo com GOMES (1996), o DNC-Departamento Nacional de Combustiveis editou a portaria número 24 de 07/06/94 que define que o preço do gás deve ser equivalente a $75 \%$ do preço do óleo combustivel tipo 1-A (ex-frete e tributos).

Informações mais recentes sobre o preço do gás natural fornecidas pela empresa SOLORRICO SA (1998)1, uma das acionárias da Holding Fertifós, indicam que a PETROBRÁS, através de sua diretoria, vem flexibilizando os preços de todos os hidrocarbonetos utilizados como matéria-prima na indústria de fertilizantes minerais nitrogenados (gás natural, gás de refinaria e

\footnotetext{
${ }^{1}$ comunicação pessoal: Benedito da Silva Ferreira, diretor da empresa SOLORRICO SA, maio de 1998.
} 
RASF), adaptando-os ao mercado. Atualmente os preços domésticos do gás natural e gás de refinaria estão atrelados aos preços do gás natural do Golfo e o preço do RASF (residuo asfáltico), após um ano de negociação com a PETROBRÁS, está atrelado às flutuações do preço da uréia no mercado internacional (SOLORRICO SA, 1998).

Com a edição da nova lei do petróleo, a criação da Agência Nacional do Petróleo - ANP e da competência estadual para regulação do preço do gás natural, a liberalização econômica e o acesso a novas fontes (Bolivia, através do gasoduto, por exemplo), este quadro deve se alterar, com aumento nos preços na fase inicial, decorrente do realismo de mercado.

Uma análise econométrica feita por DIESEL (1996) do processo de formação dos preços de fertilizantes indica que a variável custo de produção apresentou participação expressiva na variação dos preços industriais deste insumo. 0 que também ocorreu com a variável preço do fertilizante no mercado internacional. Outro resultado interessante foi obtido com relação à eficiência na produção dos insumos base, que provocaria efeito em cadeia na indústria de fertilizantes, permitindo alcançar niveis mais altos de competitividade.

Existe mais uma variável importante com relação ao custo final do insumo que é 0 transporte. A maior parte dos fertilizantes $(60,7 \%)$ percorrem distâncias superiores a $300 \mathrm{~km}$.

\begin{tabular}{l|c|c|c|c} 
classes $(\mathrm{km})$ & 0 a 100 & 100 a 300 & 300 a 500 & $>500$ \\
\hline$\%$ do expedido & 18,1 & 21,8 & 25,6 & 35,1
\end{tabular}

Essas distâncias acrescentam um custo adicional ao produto posto na propriedade agricola não só financeiros como energéticos, devido ao já elevado valor energético que os FMN apresentam e porque este transporte é feito em sua maioria $(87,2 \%)$ por meio de rodovias (BRAUN, 1990).

No caso da construção de novas unidades para fabricação de fertilizantes, será importante estudar adequadamente as oportunidades de localização destas fábricas em relação aos centros consumidores para reduzir os custos com transporte. Atualmente, os fertilizantes são produzidos na costa brasileira, longe da região Centro-oeste - que está se transformando em um grande pólo agricola consumidor de fertilizantes. Além disso, após transportar o fertilizante, os produtos agrícolas (principalmente grãos) lá produzidos têm de novamente ser trazidos para as regiões Sul e Sudeste, mais próximas da costa brasileira, onde ainda se concentram as atividades demandadoras de grãos: avicultura e suinocultura, apesar de já estar ocorrendo um deslocamento destas atividades para o Centro-oeste. 
Um exemplo para um estudo de otimização econômica dos custos globais de produção $\mathrm{e}$ uso de fertilizantes minerais nitrogenados é a utilização do gás natural da Bolivia que vai ser comercializado no Brasil através do gasoduto. A instalação de mais um pólo produtor de FMN no estado de São Paulo - onde esta matéria-prima vai ser oferecida a um custo de US\$3,00/MBTU aproximadamente, e o produto final (FMN) terá de ser transportado de volta via rodovias para a região centro-oeste para ser consumido pelos agricultores e, finalmente, onde a produção agricola deverá ser escoada também via rodovias de volta para as regiōes Sul e Sudeste - resultará em um "passeio" do hidrogênio, primeiro na forma de metano da Bolivia para São Paulo, depois na forma de uréia, de São Paulo para o Centro-oeste e, finalmente, na forma de aminoácidos, do centrooeste para o sul e sudeste. Uma forma de minimizar este "passeio" seria a construção de um pólo produtor de FMN no Mato Grosso do Sul, onde o gás natural não terá o custo do transporte via gasoduto embutido no seu preço e onde os FMN já estariam sendo produzidos próximos a um centro consumidor.

\subsubsection{Oferta de Nitrogênio no Brasil}

A quantidade de nitrogênio ofertada no Brasil pode ser dividida em fases distintas de acordo com a variação da capacidade de produção doméstica e o desenvolvimento da agricultura (gráfico 3.1). 
Gráfico 3.1. Evolução da produção, importação e consumo aparente de nitrogênio no Brasil.

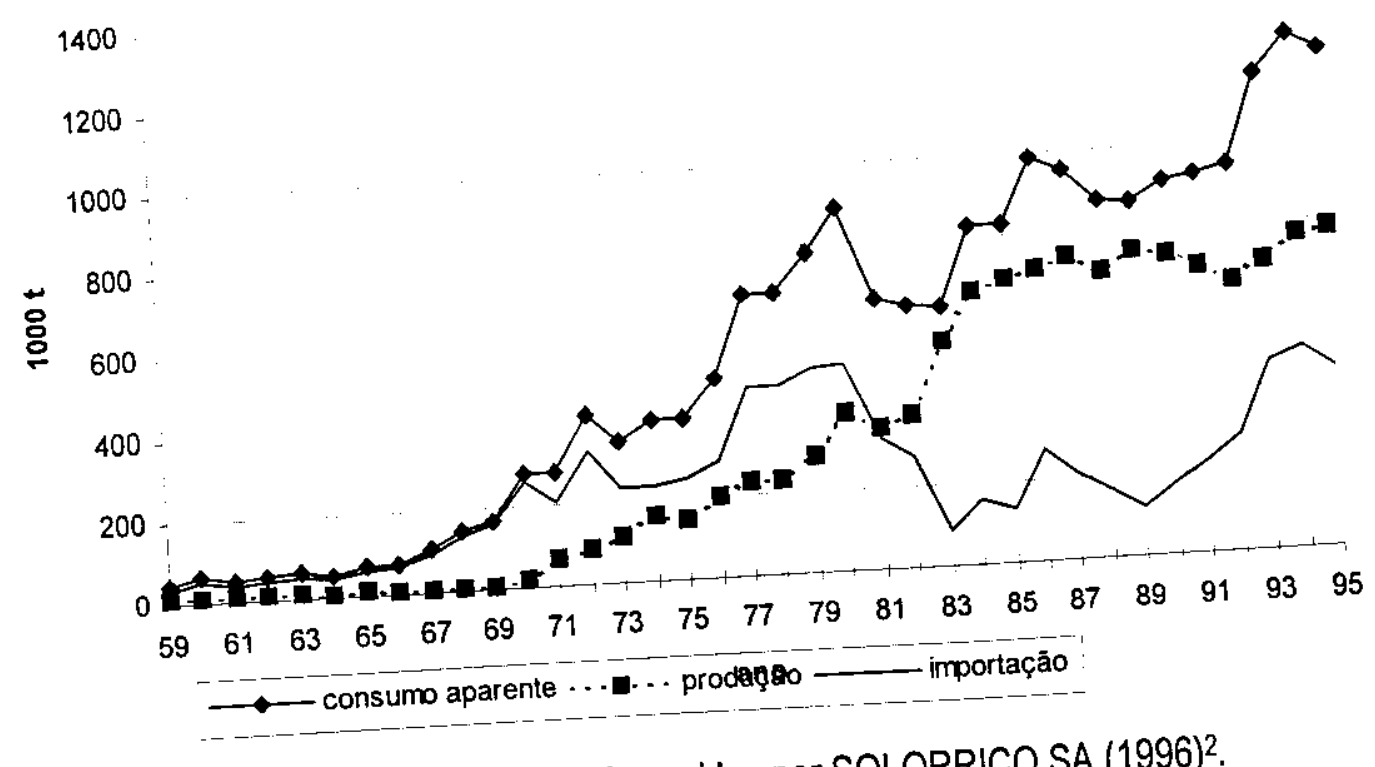

fonte: adaptado de NEPTUNE (1986) e dados fornecidos por SOLORRICO,SA (1996)2.

No inicio da década de sessenta, tanto a produção quanto o consumo de fertilizantes era insignificante por causa do baixo índice de adoção desta tecnologia por parte dos agricultores.

A década de setenta é marcada pelo início da produção interna significativa. 0 objetivo principal de se aumentar a oferta doméstica era atingir a auto-suficiência para evitar a dependência extema por derivados de petróleo após as crises de 70 e 72 além de se procurar atingir os objetivos impostos pela politica de substituição das importações de produtos industrializados iniciada na década de 60 . Como mostra a tabela 3.3 , este periodo apresentou a taxa de crescimento mais elevada da produção no pais, atingindo o valor de $34 \%$ a.a..

Tabela 3.3. Taxas de crescimento da produção e importação de nitrogênio no Brasil.

\begin{tabular}{r|rr}
\hline periodo & produção & importação \\
\hline $60-70$ & $3,63 \%$ & $17,74 \%$ \\
$70-80$ & $34,41 \%$ & $6,97 \%$ \\
$80-90$ & $6,71 \%$ & $-9,95 \%$ \\
$90-95$ & $1,14 \%$ & $20,11 \%$ \\
\hline
\end{tabular}

fonte: Elaborado a partir de NEPTUNE (1986) e dados fornecidos por SOLORRICO SA (1996).

O periodo de 1980 a 1990 reflete, no inicio, ainda os éeitos da meta da auto-suficiência pregada pelo PNFCA- Plano Nacional de Fertilizantes e Calcário Agricola e, posteriormente, a 2 comunicação pessoal: fax enviado por Benedito da Silva Ferreira, diretor da SOLORRICO SA, abril de 1996. 
estagnação econômica do país e do mundo, resultando em um crescimento da oferta interna de apenas $6,71 \%$ a.a. acompanhado de um crescimento negativo das importações.

A partir de 1990, a produção de nitrogenados não sofreu modificações. Como já foi citado, este setor apresenta uma defasagem tecnológica de 10 anos em consequência da carência de investimentos. O consumo deste insumo, entretanto, se manteve em crescimento, o que resultou no aumento das importações $(20,11 \%$ a.a. $)$.

De 1993 em diante, no cenário de oferta de nitrogênio, a produção doméstica vem representando cerca de $60 \%$ do consumo aparente.

Com relação à amônia (gráfico 3.2 ), observa-se que as importações não têm grande participação quando comparadas aos fertilizantes propriamente ditos. Isto acontece porque não existe possibilidade de ampliação da capacidade de produção destes produtos, além das vantagens econômicas e físicas de se importar o produto final ao invés da matéria-prima.

Gráfico 3.2. Evolução da produção, importação e consumo aparente de amônia no Brasil.

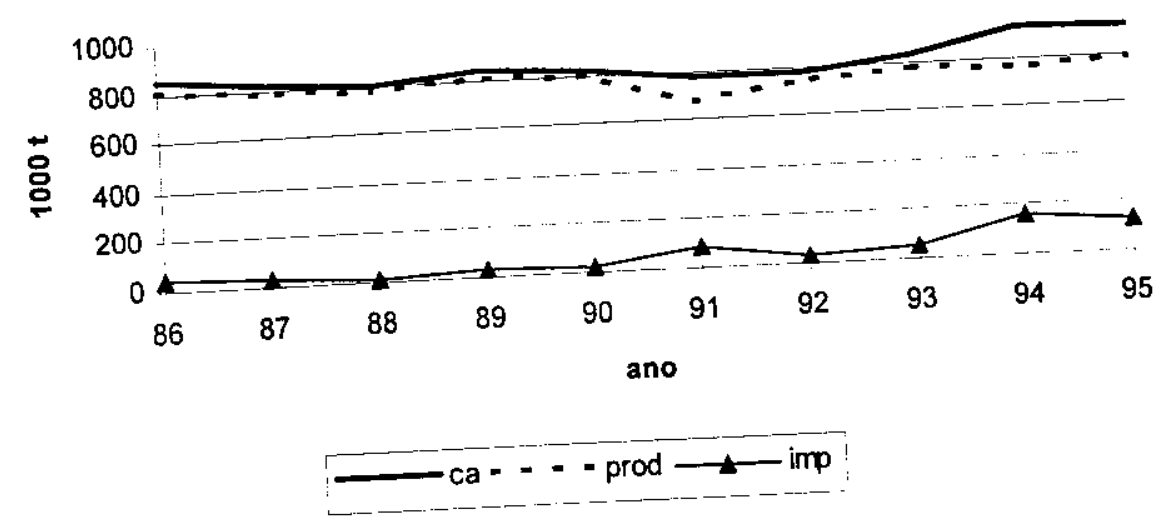

fonte: elaborado a partir de SOLORRICO, SA (1996).

Mesmo com todas estas considerações, as taxas de crescimento das importações de amônia no periodo $86-95$ foram de $13,46 \%$, enquanto a produção doméstica apresentou redução na quantidade ofertada $(-0,31 \%$ a.a.) (tabela 3.4$)$.

Tabela 3.4. Taxas de crescimento da produção, importação e consumo aparente de amônia no Brasil.

\begin{tabular}{r|r|r|r} 
periodo & $\begin{array}{r}\text { consumo } \\
\text { aparente }\end{array}$ & produção & importação \\
\hline $1986-90$ & $-0,99 \%$ & $-0,22 \%$ & $-21,21 \%$ \\
\hline $1990-95$ & $2,35 \%$ & $-0,38 \%$ & $51,90 \%$ \\
\hline $1986-95$ & $0,85 \%$ & $-0,31 \%$ & $13,46 \%$
\end{tabular}

fonte: elaborado a partir de SOLORRICO, SA (1996). 
Os dados de utilização da capacidade de produção tanto de amônia quanto de fertilizantes necessitam ser englobados à análise da situação do mercado brasileiro. Nota-se que a demanda por nitrogenados (gráfico 3.1) continua crescendo e a indústria brasileira, ao mesmo tempo, vem utilizando somente cerca de $80 \%$ de sua capacidade usual de produção (tabela 3.5 gráfico 3.3). A taxa de utilização fica menor quando se analisam os dados relativos à capacidade máxima de produção (tabela 3.6). Para amônia a redução é de $10 \%$. A tabela 3.5 fornece também uma visão mais detalhada de nossa capacidade produtiva, referenciando local da empresa, tipo de produto, capacidade de produção e regime de operação.

Tabela 3.5. Capacidade de produção e localização das indústrias produtoras.

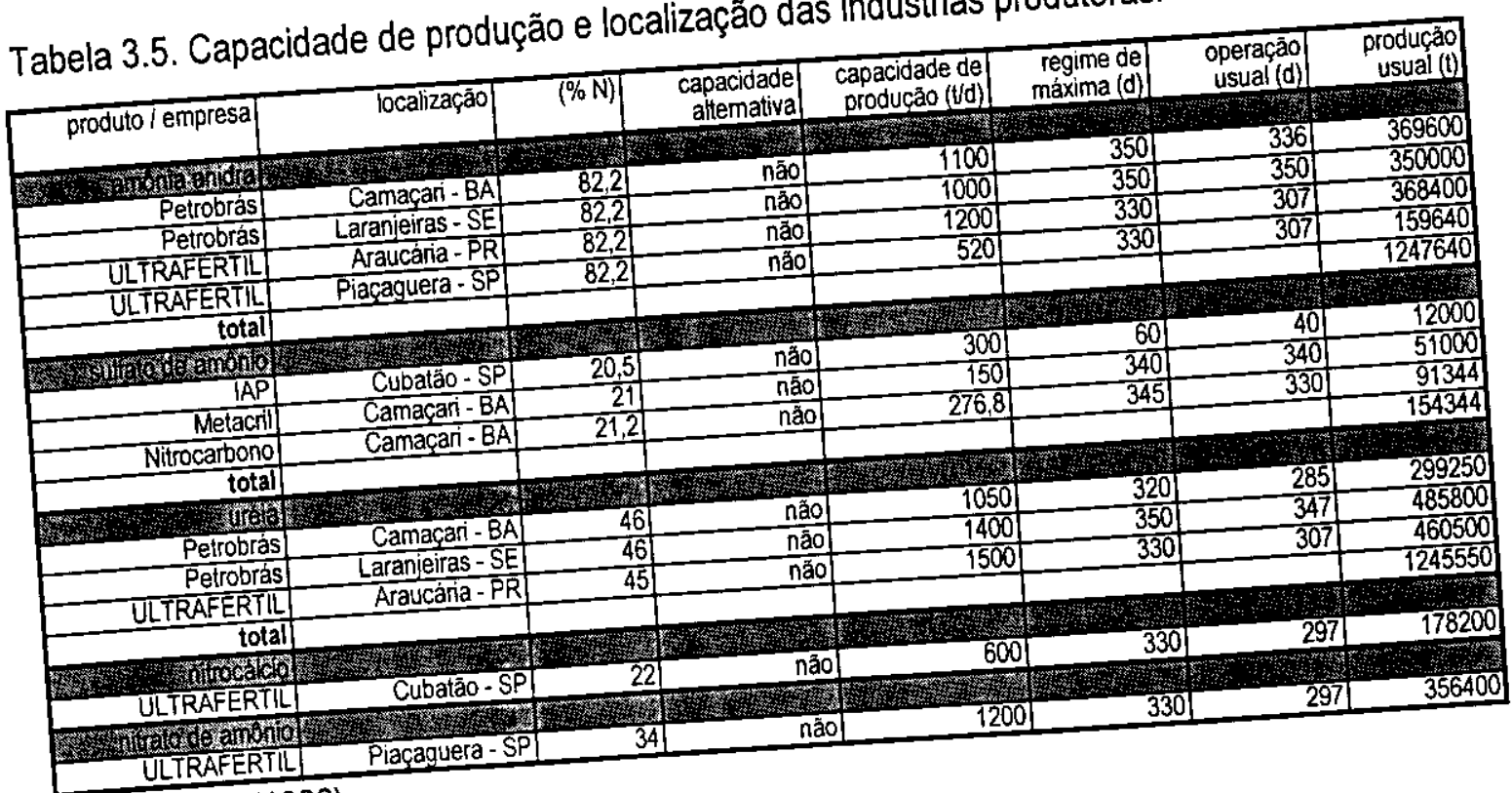

fonte: ANDA (1996). 
Gráfico 3.3. Utilização da capacidade usual de produção de fertilizantes nitrogenados e amônia.

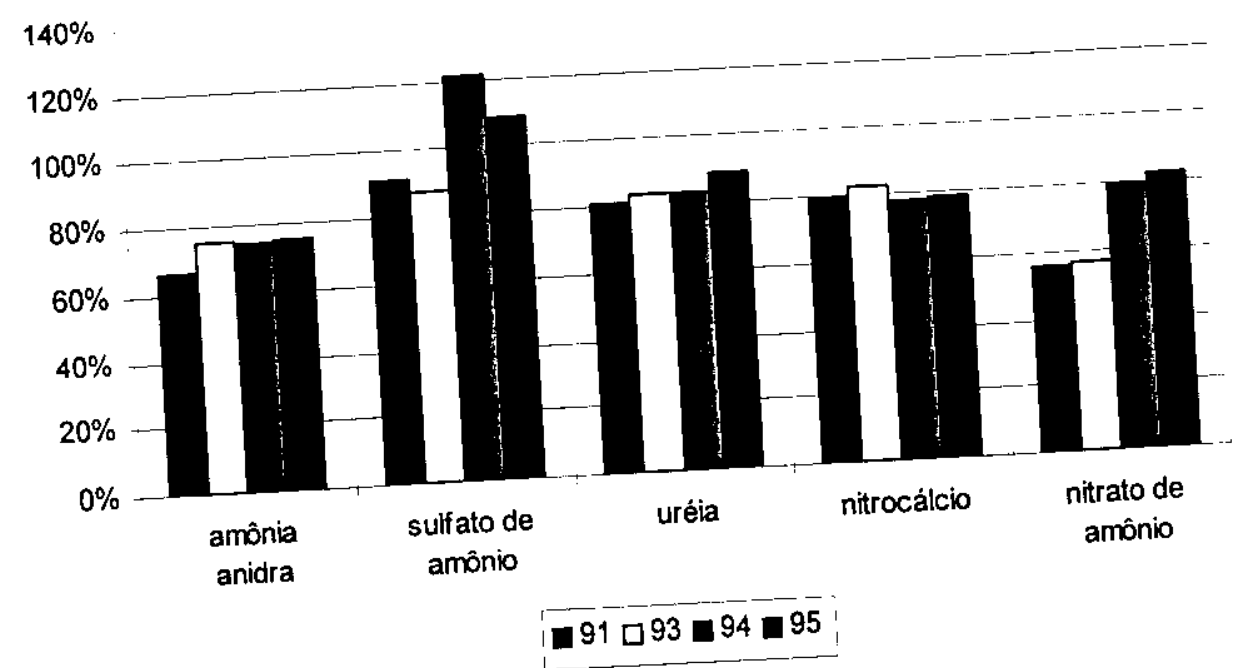

fonte: adaptado de SOLORRICO,SA (1996) e ANDA (1996).

Tabela 3.6. Taxa de utilização da capacidade máxima de produção fertilizantes nitrogenados.

\begin{tabular}{l|c|c|c|c}
\multicolumn{1}{c|}{ ano / produto } & 91 & 93 & 94 & 95 \\
\hline amônia anidra & $63,66 \%$ & $72,24 \%$ & $71,58 \%$ & $72,18 \%$ \\
\hline sulfato de amônio & $85,78 \%$ & $81,64 \%$ & $113,90 \%$ & $101,37 \%$ \\
\hline uréia & $76,58 \%$ & $78,36 \%$ & $78,66 \%$ & $83,86 \%$ \\
\hline nitrocálcio & $71,46 \%$ & $74,19 \%$ & $70,22 \%$ & $70,87 \%$ \\
\hline nitrato de amônio & $45,34 \%$ & $46,39 \%$ & $64,65 \%$ & $67,48 \%$ \\
\hline a partir de ANDA (1996) e SOLORRICO, SA (1996).
\end{tabular}

fonte: elaborado a partir de ANDA (1996) e SOLORRICO, SA (1996).

A diferença de preços entre o mercado nacional e internacional é uma justificativa para este cenário. A discrepância observada (gráfico 3.4) é causada, no mercado interno, pelo custo de produção elevado em consequência do atraso tecnológico e da já citada política de preços das matérias-primas (gás natural, gás de refinaria e residuo asfáltico). No mercado intemacional, a estratégia das empresas produtoras de fertilizantes praticando preços que apenas remuneram seus custos variáveis, em busca de novos mercados, impede qualquer possibilidade de competição. 
Gráfico 3.4. Preços da amônia no mercado nacional e internacional, 1986 a 1996.

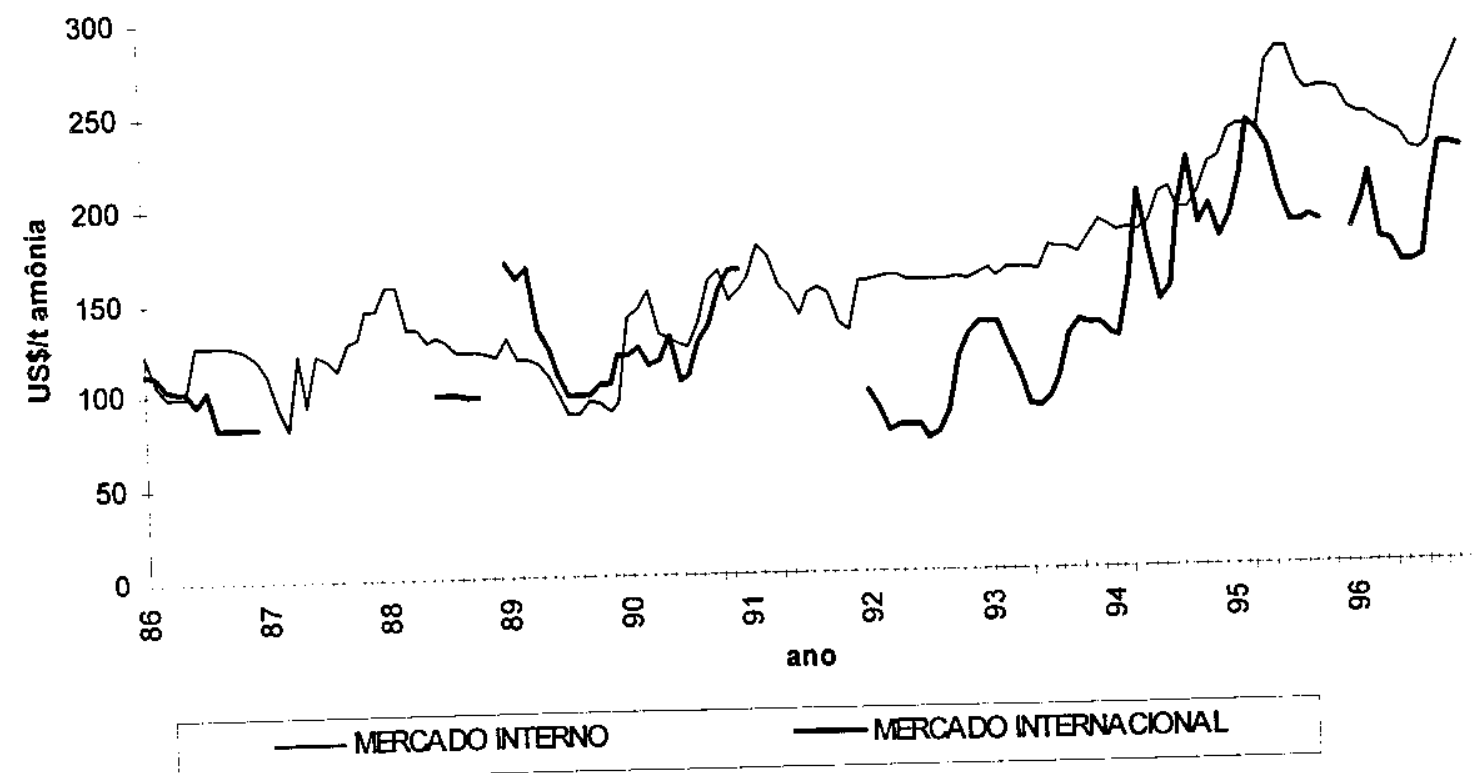

fonte: elaborado a partir de ANDA (vários anos).

O mercado de fertilizantes minerais nitrogenados no Brasil tem na uréia seu principal produto tanto na produção interna como na importação (gráfico 3.5). É o fertilizante simples de maior capacidade de produção no pais e, por apresentar alta concentração de nitrogênio (45\%), apresenta a maior participação em termos de fornecimento deste nutriente (gráfico 3.6). 0 sulfato de amônio é o segundo fertilizante mais consumido no país, mas sua produção é restrita pela ausência da oferta doméstica da matéria-prima enxofre. O fertilizante composto MAP (nitrogênio e fósforo) está representado como o terceiro produto mais consumido (importação e produção), mas como fornecedor de nitrogênio sua participação é baixa porque só possui $10 \%$ deste nutriente em sua formulação. 
Gráfico 3.5. Produção e importação de fertilizantes nitrogenados, Brasil - 1995.

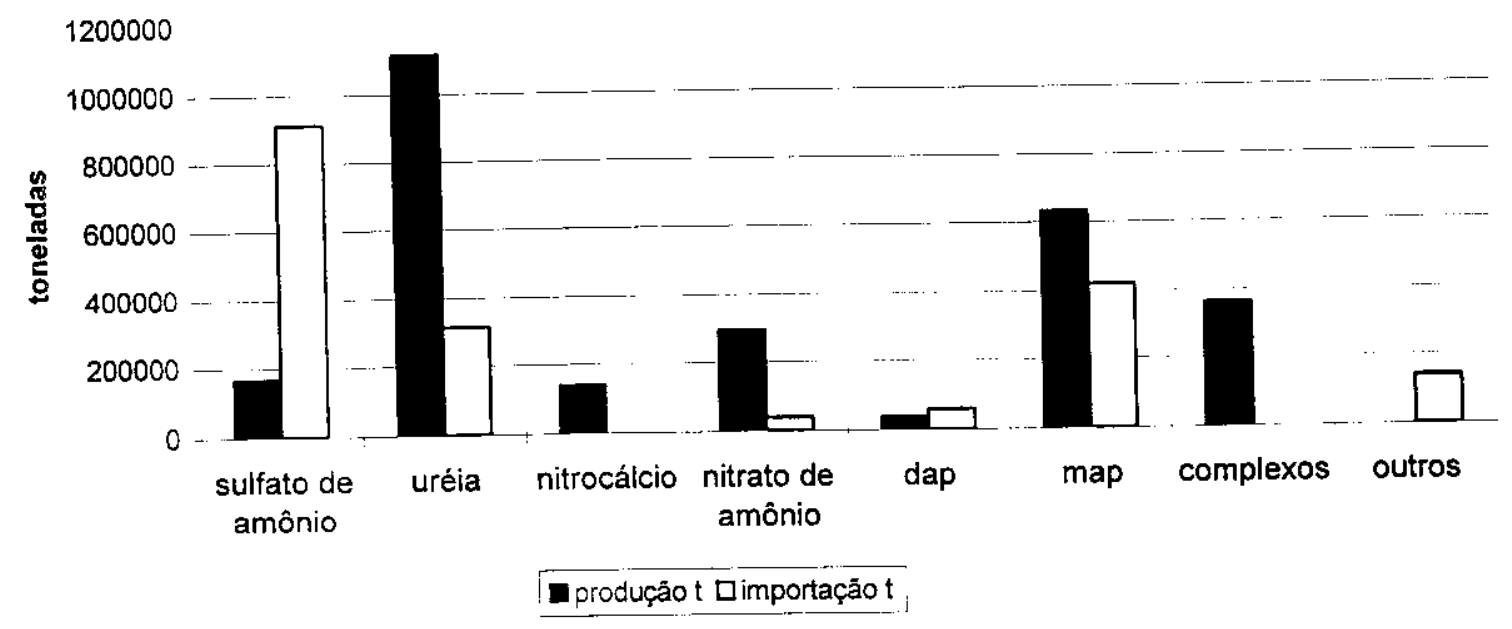

fonte: elaborado a partir de BRUNO et al. (1985) e ANDA (1996).

Gráfico 3.6. Produção e importação de fertilizantes nitrogenados (t de N), Brasil - 1995.

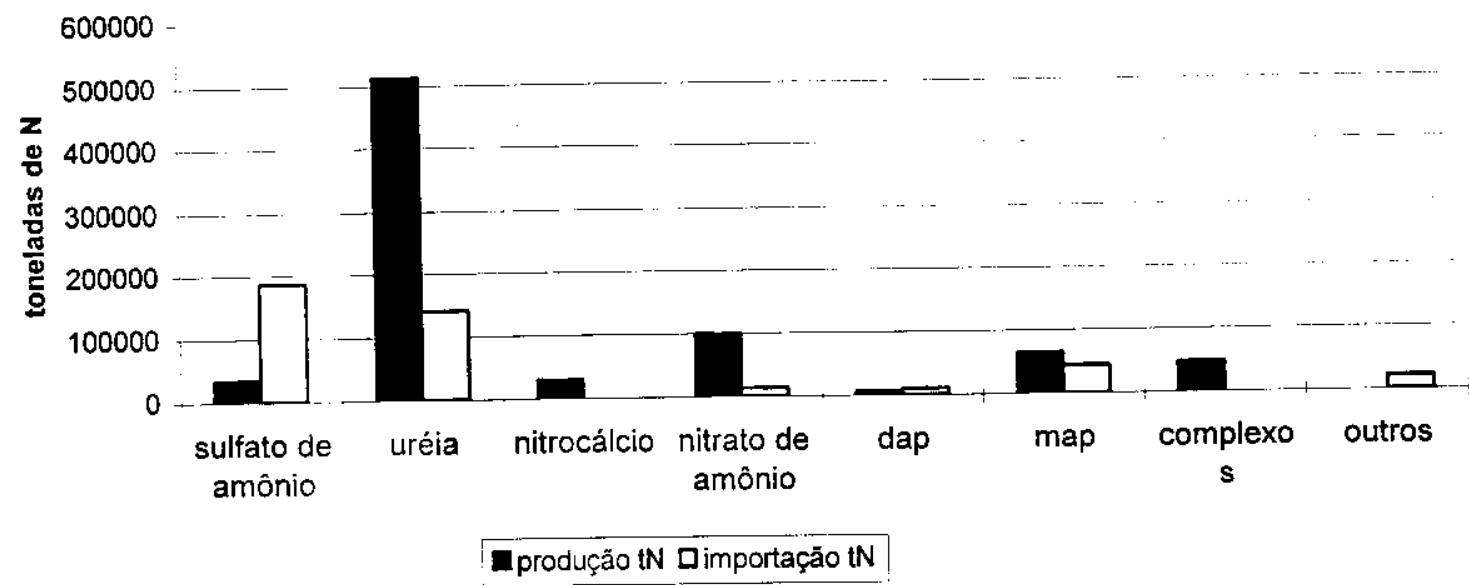

fonte: elaborado a partir de BRUNO et al. (1985) e ANDA (1996).

A uréia é o fertilizante que apresenta o maior consumo de energia dentre os fertilizantes nitrogenados, por duas razões: é o fertilizante nitrogenado produzido em maior quantidade e, demanda mais energia por tonelada de fertilizante produzido (gráfico 3.7). 
Gráfico 3.7. Energia total consumida para fabricação de fertilizantes nitrogenados por tipo de produto, Brasil - 1995.

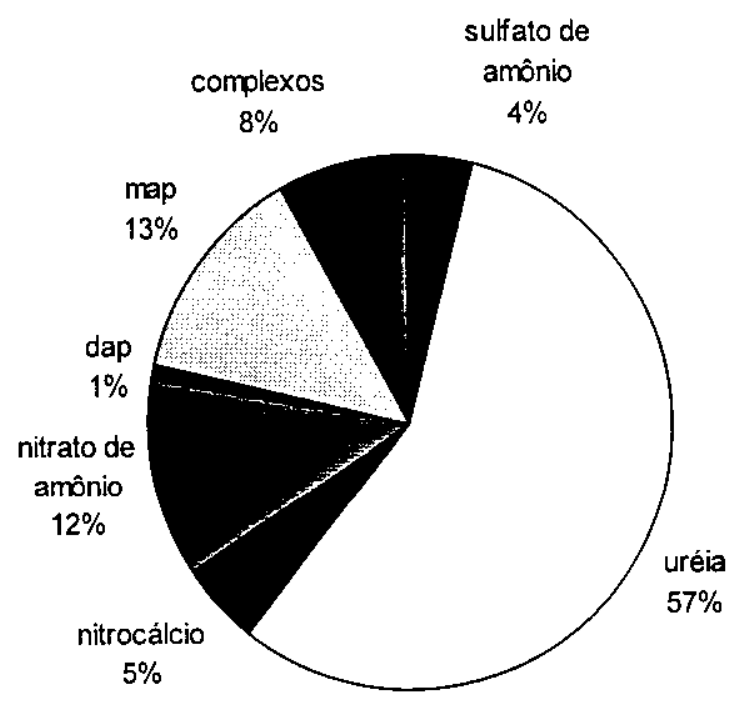

fonte: elaborado a partir de BRUNO et al. (1985) e ANDA (1996).

\subsection{Processos Industriais de Fabricação de Amônia}

A história da produção industrial de amônia começou na Alemanha no inicio do século, quando Fritz Haber e seus assistentes desenvolveram o conceito do processo que é a base para a produção de amônia até os dias de hoje. Nos anos de 1904-1908, os dados de equilibrio do sistema amoníaco-nitrogênio-hidrogênio foram estabelecidos com precisão e domínio de temperaturas e pressões. O processo Haber-Bosch é baseado na conversão catalítica do hidrogênio e do nitrogênio.

A primeira planta comercial de produção de amônia foi colocada em operação em 1913. 0 governo alemão, neste periodo, necessitava de grandes quantidades de explosivos nitrogenados e, por isto, financiou o desenvolvimento desta tecnologia (BEER et al., 1995).

Depois da Primeira Guerra Mundial, o processo Haber-Bosh tornou-se economicamente mais acessivel, o que estimulou o desenvolvimento e implantação, em outras partes do mundo, de plantas de amônia com processos similares (BEER et al., 1995).

No periodo de 1920 a 1990, o processo Haber-Bosch sofreu grandes mudanças no âmbito da eficiência do processo e da questão econômica. A capacidade de produção aumentou de 150 
tdia em 1950 para 1000 tdia nos anos 70 . Somente em 1950 surgiram as plantas baseadas na reforma com vapor de gás natural. Antes disso, o hidrogênio era obtido do carvão (BEER et al., 1995).

Antes da crise do petróleo no ano de 1973, a eficiência energética das plantas de amônia não era considerada muito importante. Depois do choque, entretanto, tal questão tornou-se um consenso. Os esforços resultaram em modificações: o consumo total de energia foi reduzido de, aproximadamente, $10 \mathrm{Gcal} / \mathrm{Mt}$ de amônia para as plantas mais antigas para $7 \mathrm{Gcal} / \mathrm{Mt}$ de amônia nas plantas modernas.

WORREL \& BEER (1995) afirmam que a indústria de fertilizantes nitrogenados é uma grande consumidora de energia ( $1 \%$ da demanda global de energia), com uma capacidade mundial de produção de 100 Mtoneladas de nitrogênio por ano. 0 processo mais intensivo energeticamente é a produção de amônia.

A evolução do consumo de energia para a produção de amônia está ilustrada no gráfico 3.8, desde o início do século até os processos modernos que se aproximam do mínimo teórico.

Gráfico 3.8. Evolução do consumo energético para produção de amônia.

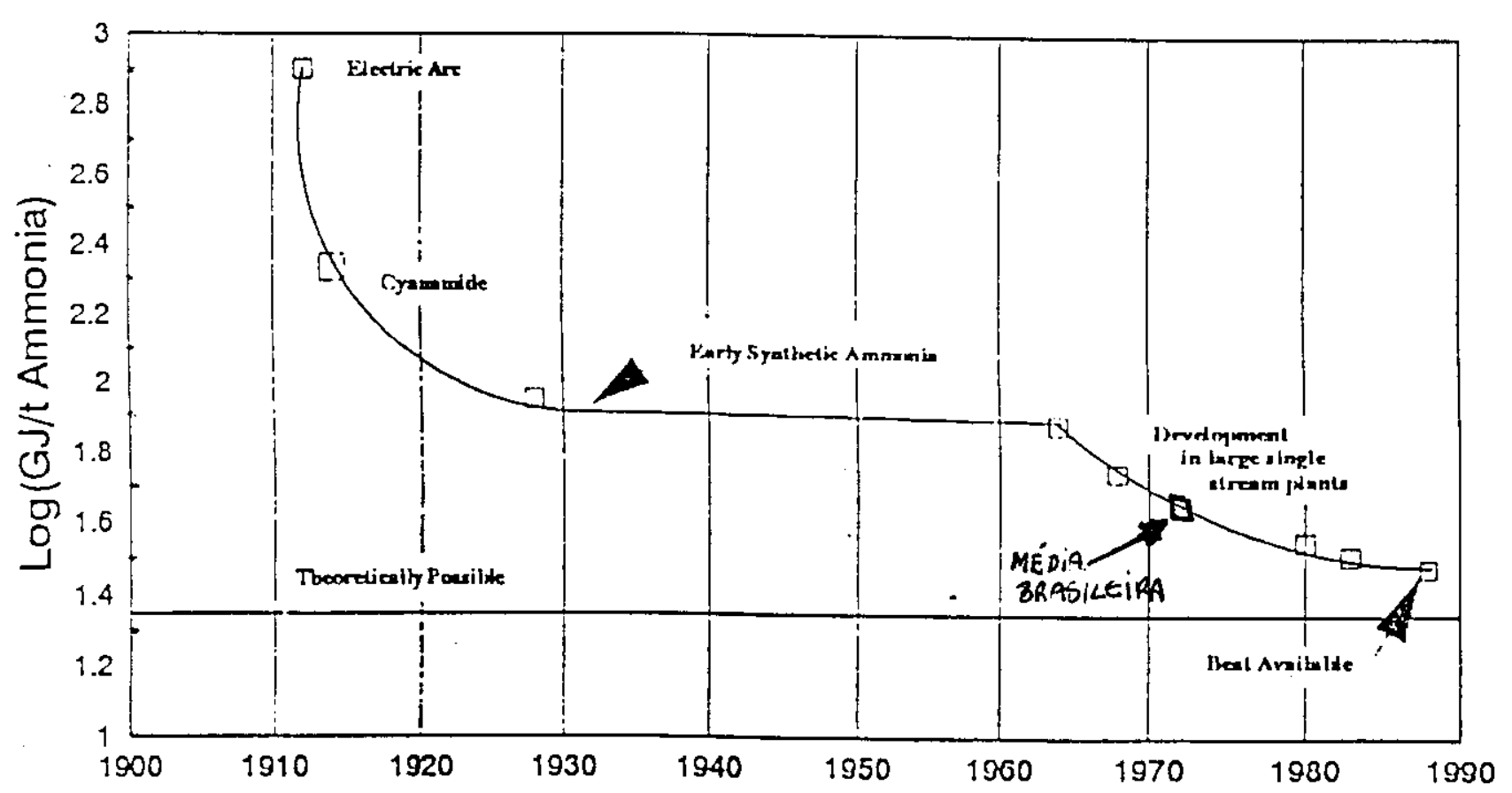

fonte: WORREL \& BEER (1995). 
BEER et al. (1995) consideram que, desde a instalação da primeira planta comercial de produção de amônia em 1913, pode-se observar dois marcos importantes: o primeiro com a introdução dos processos de corrente única na década de 60 e o segundo na década de 80 , com a introdução dos processos altamente eficientes.

A amônia é produzida através da sintese de gases a alta pressão. Os processos utilizados para obter o hidrogênio como gás reagente para a sintese de amônia são oxidação parcial de hidrocarbonetos e reforma com vapor.

Apesar do processo de oxidação parcial ser mais flexivel quanto ao tipo de hidrocarboneto empregado, seu consumo energético é 40 a $50 \%$ maior do que no processo de reforma com vapor. Isto se deve ao alto consumo de energia para obter o hidrogênio da matéria-prima.

O gás natural é a matéria-prima mais usual para produção de amônia e é considerada a matéria-prima do futuro por resultar em um processo energeticamente mais eficiente quando comparado a outras matérias-primas e, consequentemente, apresentar custos de produção menores. Planos recentes para a construção de novas plantas de amônia indicam que quase $80 \%$ da nova capacidade utilizará gás natural como matéria-prima. Reforma com vapor é o processo utilizado em $80 \%$ da capacidade mundial de produção.

Para uma melhor compreensão, o processo de reforma com vapor d'água está brevemente descrito no ANEXO 1.

Segundo HONTI (1981), para unidades à base de gás natural, $85 \%$ da energia requerida pelo processo é suprida por recuperação de calor. A maior parcela de energia disponível para recuperação é reciclada através de geração de vapor d'água. Mesmo assim, há necessidade de geração complementar de vapor d'água através de uma caldeira auxiliar.

A caldeira auxiliar utiliza, em geral, como combustivel o mesmo insumo energético empregado no reformador primário. Este último equipamento é o principal ponto de consumo em termos do combustivel alimentado a uma unidade de amônia que opera pelo processo de reforma com vapor.

Os principais usos de vapor d'água são: como matéria-prima em várias etapas da fase de produção de gás de sintese, e no trabalho de compressão da operação de síntese, pelo acionamento da turbina do compressor.

Energia elétrica é majoritariamente aplicada em acionamento. A potência total (suprida com vapor e eletricidade) usada para acionamento é indicada como sendo da ordem de $35 \mathrm{MW}$ para 
uma unidade com capacidade de 1000 t/d de amônia. A principal parcela desta potência, entre 15 a $20 \mathrm{MW}$, é consumida na turbina do compressor da síntese.

\subsection{Aspectos Ambientais da Producão de Amônia}

A indústria de amônia através da combustão de hidrocarbonetos na fornalha do reformador primário, nos queimadores dos aquecedores e caldeiras auxiliares é uma emissora de gases causadores do efeito estufa, como dióxido de carbono e óxidos de nitrogênio. Além disso, o dióxido de carbono é produzido como resultado da reação para produção da amônia:

$$
3 \mathrm{CH}_{4}+6 \mathrm{H}_{2} \mathrm{O}+4 \mathrm{~N}_{2} \rightleftarrows 3 \mathrm{CO}_{2}+12 \mathrm{H}_{2}+4 \mathrm{~N}_{2} \rightleftarrows 8 \mathrm{NH}_{3}+3 \mathrm{CO}_{2}^{3}
$$

Todo o carbono contido nos hidrocarbonetos empregados como matéria-prima é convertido em dióxido de carbono. Atuaimente, esse gás é recuperado e utilizado para produção de uréia, nas unidades integradas de produção amônia-uréia (razão molar $\mathrm{CO}_{2} / \mathrm{NH}_{3}$ de 0,5 é a relação estequiométrica necessária para produção de uréia). De acordo com a EFMA (1995) e NITROGEN (1997), a produção de $\mathrm{CO}_{2}$ na sintese de amônia através de reforma com vapor de gás natural é de 1,15 a $1,30 \mathrm{~kg} / \mathrm{kg} \mathrm{NH}$.

A combustão é responsável pela emissão de 0,5 a $0,35 \mathrm{t} \mathrm{CO}_{2} / \mathrm{NH}_{3}$ e 0,6 a $1,3 \mathrm{~kg} \mathrm{NO} \times / \mathrm{t}$ $\mathrm{NH}_{3}$ (EFMA, 1995 e NITROGEN, 1997), dependendo do grau de ar injetado no reformador secundário, a quantidade de oxigênio disponivel e o conteúdo de nitrogênio elementar presente no ar de combustão.

Comparada com outros emissores de óxidos de nitrogênio, a indústria de amônia não representa uma grande contribuição. A emissão mundial de $\mathrm{NO}_{\mathrm{x}}$ proveniente das atividades humanas em 1990 foi de $110 \times 10^{6} \mathrm{t}$, com uma produção de amônia da ordem de $120 \times 10^{6}$ t e assumindo um valor de $1,5 \mathrm{~kg} \mathrm{NO} / \mathrm{t}$ amônia, a contribuição deste setor seria equivalente a $0,16 \%$ das emissões totais (NITROGEN, 1997).

Um ponto importante a ser discutido com relação às emissões é a utilização do dióxido de carbono emitido na produção de amônia para produção de uréia (1,29 t $\mathrm{CO}_{2} /$ amônia convertida). Afirma-se que, devido a este aproveitamento, não existe a adição deste gás causador do efeito estufa à atmosfera, porém, quando este fertilizante vier a ser aplicado ao solo para a disponibilização do nitrogênio às plantas, ocorre a seguinte reação:

3 equação representando a proporção estequiométrica. 


$$
\mathrm{CO}\left(\mathrm{NH}_{2}\right)_{2}+\mathrm{H}_{2} \mathrm{O} \longrightarrow\left(\mathrm{NH}_{4}\right)_{2} \mathrm{CO}_{3} \rightarrow 2 \mathrm{NH}_{3}+\mathrm{CO}_{2}
$$

Constata-se que a fixação do dióxido de carbono é apenas temporária, até o momento em que a uréia é aplicada ao solo. Além disso, para a produção dos demais fertilizantes, necessita-se de amônia e não existe demanda por $\mathrm{CO}_{2}$, o que indica um lançamento deste gás na atmosfera proveniente da produção da amônia. Entretanto, quando a adição de uréia resultar na elevação da produtividade de uma cultura, estará acontecendo também uma maior retirada de carbono da atmosfera na forma de dióxido de carbono, através da maior formação de material vegetal.

\subsection{Diagnóstico da Indústria Brasileira de Amônia}

Para identificar e propor medidas de conservação de energia na indústria de amônia no Brasil, efetuou-se um diagnóstico deste setor. A base de dados deste diagnóstico é o trabalho do IPT (Instituto de Pesquisas Tecnológicas) "Conservação de Energia na Indústria de Fertilizantes" elaborado por BRUNO et al. em 1985.

Com o objetivo de atualizar os dados de 1985, enviou-se um questionário (ANEXO 2) aos produtores de amônia utilizada no processo de obtenção de fertilizantes no pais: empresa ULTRAFÉRTIL - Cubatão-SP e PETROBRÁS em Camaçari-BA e Laranjeiras-SE, porque não existe nenhuma outra pesquisa detalhada da indústria de fertilizantes minerais nitrogenados posterior à do IPT. Além do questionário, a bibliografia especializada e entrevistas com especialistas também foram utilizadas para a atualização dos dados.

Este item se restringirá a fornecer informações de caráter tecnológico a respeito das unidades de sintese de amônia brasileiras.

Com relação ao processo de fabricação, no Brasil, são empregados atualmente o processo clássico de reforma com vapor d'água e o de oxidação parcial. Cabe ressaltar que a análise se restringirá às unidades de produção de amônia que empregam o processo de reforma catalitica com vapor d'água, pelo fato de não existirem dados disponiveis para a tecnologia de oxidação parcial utilizando a matéria-prima resíduo asfáltico.

As matérias-primas processadas pela indústria brasileira são: gás natural, gás natural associado a petróleo, gás residual de refinaria e óleo residual asfáltico (tabela 3.7).

A idade das plantas brasileiras é um indicativo do seu potencial de conservação de energia, na medida que se identifica o estágio de desenvolvimento tecnológico do periodo de sua 
instalação. O Brasil possui plantas de amônia com idade entre 27 a 15 anos de operação, o que pode significar um processo de baixa eficiência energética, principalmente se não foi efetuado revamp ao longo da vida da unidade.

Tabela 3.7. Tecnologias empregadas no Brasil pelas unidades de fabricação de amônia para fins fertilizantes.

\begin{tabular}{|c|c|c|c|c|}
\hline $\begin{array}{l}\text { empresa / } \\
\text { capacidade }\end{array}$ & $\begin{array}{c}\text { locall } \\
\text { instalação }\end{array}$ & $\begin{array}{l}\text { matéria- } \\
\text { prima }\end{array}$ & $\begin{array}{c}\text { tecnologia } \\
\text { gás de síntese } \\
\text { (licenciador) }\end{array}$ & $\begin{array}{l}\text { tecnologia } \\
\text { síntese } \\
\text { (licenciador) }\end{array}$ \\
\hline $\begin{array}{l}\text { ULTRAFÉRTIL } \\
520 \mathrm{t} / \mathrm{d}\end{array}$ & $\begin{array}{c}\text { Piaçaguera, } \\
\text { SP } \\
(1970)\end{array}$ & $\begin{array}{l}\text { Gás de } \\
\text { refinaria }\end{array}$ & $\begin{array}{l}\text { reforma com vapor } \\
\text { FOSTER } \\
\text { WHEELER }(30 \mathrm{~atm})\end{array}$ & $\mathrm{ICl}$ (140atm) \\
\hline $\begin{array}{l}\text { ULTRAFÉRTIL } \\
1200 \mathrm{td} \\
\end{array}$ & $\begin{array}{c}\text { Araucária, PA } \\
\text { (1982) }\end{array}$ & $\begin{array}{l}\text { Resíduo } \\
\text { asfáltico }\end{array}$ & $\begin{array}{c}\text { oxidação parcial } \\
\text { SHELL/LURGI } \\
(47 \mathrm{~atm})\end{array}$ & $\begin{array}{l}\text { KOBE STEEL/UHDE } \\
\text { (220atm } \\
\text { HALDOR-TOPSOE }\end{array}$ \\
\hline $\begin{array}{l}\text { Petrobrás } \\
1100 \mathrm{t} / \mathrm{d}\end{array}$ & $\begin{array}{c}\text { Camaçari, BA } \\
(1978) \\
\end{array}$ & Gás natural & $\begin{array}{l}\text { reforma com vapor } \\
\text { KELLOGG (34atm) }\end{array}$ & $\begin{array}{l}\text { KELLOGG } \\
\text { (140atm) }\end{array}$ \\
\hline $\begin{array}{l}\text { Petrobrás } \\
1000 \mathrm{t} / \mathrm{d}\end{array}$ & $\begin{array}{c}\text { Larangeiras, } \\
\text { SE } \\
(1982) \\
\end{array}$ & $\begin{array}{l}\text { Gás natural } \\
\text { assoc. }\end{array}$ & $\begin{array}{l}\text { reforma com vapor } \\
\text { KELLOGG (34atm) }\end{array}$ & $\begin{array}{l}\text { KELLOGG } \\
\text { (140atm) }\end{array}$ \\
\hline
\end{tabular}

fonte: adaptado de CEKINSKI (1990) e BRUNO et al. (1985).

Da capacidade total instalada de produção anual de amônia, $12,8 \%$ utiliza o gás de refinaria, $57,7 \%$ emprega o gás natural e $29,5 \%$ utiliza residuo asfáltico como matéria-prima (ANDA, 1995).

Em termos de energia, a participação dos insumos hidrocarbonetos como matéria-prima e combustivel é: $70 \%$ gás natural, $22 \%$ residuo asfáltico e $8 \%$ gás de refinaria (BRUNO et al., 1985). Fica evidenciada maior participação relativa de gás natural em termos de energia para os insumos utilizados como matéria-prima e combustivel, pois este alimenta duas unidades industriais de grande porte. A parcela referente ao residuo asfáltico é significativa, sendo este insumo utilizado em apenas uma unidade industrial de grande porte (Araucária-PA, ver tabela 3.7).

A seguir serão apresentados os índices de consumo específico de energia das unidades amostradas pelo IPT, em 1985 (tabela 3.8). 
Tabela 3.8. Consumos especificos de energia das unidades produtoras de amônia.

\begin{tabular}{|l|l|rrrrrr|}
\hline & & \multicolumn{5}{|c|}{ consumos especificos $\left(\mathrm{GJ}_{\mathrm{J}} / \mathrm{NH}_{3}\right)$} \\
\cline { 3 - 8 } unidade industrial & matéria-prima & $\mathrm{CE}_{\mathrm{v}}$ & $\mathrm{CE}_{\mathrm{EL}}$ & $\mathrm{CE}_{\mathrm{C}}$ & $\mathrm{CEE}_{\mathrm{p}}$ & $\mathrm{CEE}_{\mathrm{eq}}$ & $\mathrm{CEE}_{\mathrm{G}}$ \\
Laranjeiras, SE & gás natural & $-2,31$ & 1,01 & 11,42 & 10,12 & 24,15 & 34,27 \\
Camaçari, $\mathrm{BA}$ & gás natural & $-3,90$ & 3,23 & 11,65 & 10,98 & 23,68 & 34,66 \\
Piaçaguera, SP & gás refinaria & $-3,14$ & 4,13 & 11,98 & 12,97 & 24,52 & 37,49 \\
Araucária, PA & RASF & 7,61 & 0,44 & $-2,02$ & 6,03 & 35,14 & 41,17 \\
\hline
\end{tabular}

CE $E_{y}$ consumo específico de vapor

CEEl consumo especifico de eletricidade

$\mathrm{CEE}_{p}=\mathrm{CE}_{\mathrm{v}}+\mathrm{CEEL}+\mathrm{CE} \mathrm{C}$ consumo específico de energia de processo

CEc consumo específico de combustiveis

$\mathrm{CEE}_{\text {eq }}$ consumo específico de energia correspondente a matéria-prima

$\mathrm{CEE}_{\mathrm{G}}=\mathrm{CEE}_{\mathrm{p}}+\mathrm{CEE}_{\mathrm{eq}}$ consumo especííco global de energia

obs: os valores negativos representam a entalpia do vapor exportado da unidade.

fonte: BRUNO et al. (1985).

De acordo com CEKINSKI et al. (1990), as unidades de amônia de Camaçari-BA, PETROBRÁS e da ULTRAFÉRTIL de Piaçaguera-SP estavam sendo "revampeadas" na época da publicação com os objetivos apresentados no quadro 3.1.

Quadro 3.1. Modificações previstas para as plantas de amônia do Brasil.

\begin{tabular}{|ll|}
\hline \multicolumn{1}{|c|}{ local/ modificação } & \multicolumn{1}{c|}{ benefício } \\
\hline Camaçari, BA - Petrobrás & \\
- elevar a temperatura do ar de combustão no reformador & - aumentar a produção em $15 \%$ \\
secundário para deslocar a reação da reforma primária & \\
para a secundária. & \\
Piaçaguera,SP - ULTRAFÉRTIL & \\
- incorporar o sistema de recuperação criogênica do gás & - aumento da produção de $30 \%$ e \\
de purga & redução no consumo de energia em $10 \%$ \\
- sistema para a modernização da instrumentação. & \\
- modernização do reformador primário visando otimizar a \\
recuperação de energia e o fator operacional.
\end{tabular}

fonte: CEKINSKI et al. (1990).

ÁVILA (1997)4, porém, respondendo o questionário enviado à PETROBRÁS (representando as unidades de Camaçari, BA e Laranjeiras, SE) relata:

"Podemos citar que os números quanto a consumos de energia e insumos permaneceram inalterados em relação a 1985."

SANCHES (1997)5 , da ULTRAFÉRTL - Piaçaguera,SP, respondeu com os seguintes dados:

${ }^{4}$ comunicação pessoal; Paulo Ávila, da PETROBRÁS- Camaçari, BA, através do questionário enviado, setembro de 1997. 


\begin{tabular}{|l|l|}
\hline dados referentes a 1996 & valor \\
\hline consumo de combustivel (t/ano) & 47342 \\
\hline consumo de eletricidade (kwh/ano) & $2759810^{3}$ \\
\hline consumo de vapor (tano) & 1161657 \\
\hline consumo de matéria-prima(tano) & 77619 \\
\hline produção de amônia (t/ano) & 136514 \\
\hline
\end{tabular}

Para efeito de comparação com os dados fornecidos pelo IPT (1985), é necessário transformar as unidades acima em unidades de energia (GJ). A transformação resultou em:

\begin{tabular}{l|l|l|l|l} 
tipo & valor dado & transformação & GJ & GJ/t amônia \\
\hline consumo de combustivel (tlano) & 47342 & $\mathrm{PCl}-45,22 \mathrm{GJ} / \mathrm{t}$ & 2140805 & 15,68 \\
\hline consumo de eletricidade (kwh/ano) & $27598 \times 10^{3}$ & $1 \mathrm{kwh}=3600 \mathrm{kj}$ & $9,92448 \times 10^{10}$ & 0,727 \\
\hline consumo de vapor (tano) & 1161657 & - & 4766975 & $-4,10$ \\
\hline consumo matéria-prima (tano) & 77619 & $\mathrm{PCl}-45,22 \mathrm{GJ} / \mathrm{t}$ & 350993 & 25,71 \\
\hline total & 136514 & - & & 38,02
\end{tabular}

A diferença registrada entre os dados - 37,49 GJ/t NH (IPT, 1985) e 38,02 GJ/t NH (questionário, 1997) não demonstra a existência de nenhuma melhora na eficiência energética da produção de amônia nesta unidade. Não se pode afirmar também, que houve uma piora da eficiência apenas pela diferença de $0,53 \mathrm{GJ} / \mathrm{t} \mathrm{NH}$ registrada, pois este valor pode ter sido alcançado em consequência das aproximações efetuadas nas transformações de unidades.

O questionário permitiu obter mais informações relativas às tecnologias envolvidas (tabela $3.9)$.

${ }^{5}$ comunicação pessoal: Luiz Porta Nova Sanches, da Ultrafértil- Cubatão,SP, através do questionário enviado, agosto de 1997. 
Tabela 3.9. Dados obtidos através dos questionários.

\begin{tabular}{|c|c|c|c|}
\hline questões & ULTRAFERTIL, Piaçaguera & $\begin{array}{l}\text { PETROBRAS } \\
\text { Camaçari }\end{array}$ & $\begin{array}{l}\text { PETROBRAS } \\
\text { Laranjeiras }\end{array}$ \\
\hline $\begin{array}{l}\text { existência de Comissão } \\
\text { Interna de Conseryação de } \\
\text { Energia }\end{array}$ & $\begin{array}{l}\text { não possui CICE formalmente constituída, mas possui } \\
\text { área de planejamento e controle da produção que } \\
\text { efetua diariamente balanço energético, identificando a } \\
\text { performance energética }\end{array}$ & SIM & SIM \\
\hline $\begin{array}{l}\text { existência de pré- } \\
\text { aquecimento do ar de } \\
\text { combustão na fornalha do } \\
\text { reformador primário }\end{array}$ & $\mathrm{NAZO}$ & NÃO & SIM \\
\hline $\begin{array}{l}\text { existência de processo de } \\
\text { recuperação de hidrogênio } \\
\text { do gás de purga }\end{array}$ & NÃO & NAOO & NAOO \\
\hline $\begin{array}{l}\text { recuperação de calor dos } \\
\text { gases de combustão da } \\
\text { fornalha do reformador } \\
\text { primàrio } \\
\end{array}$ & NÃO & $\begin{array}{c}\text { SIM, cerca de } \\
87 \%\end{array}$ & $\begin{array}{c}\text { SIM, cerca de } \\
94 \%\end{array}$ \\
\hline $\begin{array}{l}\text { etapa de síntese de amônia: } \\
\text { compressor centrífugo } \\
\text { dois estágios de } \\
\text { condensaçáo de amônla } \\
\text { reator axial de quatro leitos }\end{array}$ & $\begin{array}{l}\text { SIM } \\
\text { SIM } \\
\text { NÃO }\end{array}$ & $\begin{array}{l}\text { SIM } \\
\text { SIM } \\
\text { SIM }\end{array}$ & $\begin{array}{l}\text { SIM } \\
\text { SIM } \\
\text { SIM }\end{array}$ \\
\hline
\end{tabular}

fonte: ÁVILA (1997) e SANCHES (1997).

Além da tabela, as respostas continham algumas observações, dentre elas, a questão de ser possivel identificar a queda da performance global do processo de sintese de amônia, mas da inviabilidade econômica de se efetuarem correções quando se efetua uma análise custo-beneficio (SANCHES, 1997). Outro dado fornecido por SANCHES (1997) é com relação à proporção de energia consumida pelo reformador primário na unidade Piaçaguera,SP: $30 \%$ de todo o consumo energético desta unidade. Segundo ele, isto ocorre por causa da existência de grandes compressores a vapor, da baixa eficiência dos reatores de sintese e da perda de carga em função da concepção do loop de síntese.

Em relação às unidades da PETROBRAS (Camaçari e Laranjeiras), ÁVILA (1997) afirmou que a Comissão Interna de Conservação de Energia tem sido capaz de identificar, ao longo do histórico operacional, oportunidades de conservação de energia. Ele cita como possiveis melhorias o isolamento térmico de determinadas linhas de processo, instalação de trocadores de calor, monitoração de excesso de ar nos fornos, monitoração periódica das perdas por paredes dos fornos e substituição de isolamentos. Entretanto, salienta que : 
"Os maiores ganhos provenientes de modificações no processo deverão ser incorporados quando da implantação dos projetos de "revamp" nas unidades de amônia de Camaçari.e Laranjeiras."

As informações mais recentes sobre a situação das indústrias de fertilizantes no pais foram encontradas em um estudo feito por RAPPEL \& LOIOLA (1993) sobre a competitividade deste segmento. Identificou-se que, desde 1985 a PETROBRÁS não realiza aportes financeiros ao grupo (a pesquisa foi concluida antes da privatização da ULTRAFÉRTIL).

Devido às dificuldades enfrentadas pelo parque produtor nacional na década de oitenta, os investimentos da PETROFÉRTIL limitaram-se às necessidades urgentes de reposição e reformas, continuidade operacional e proteção ambiental. Tal fato resultou em problemas que prejudicam a competitividade do setor, como a desatualização tecnológica do parque produtivo e a necessidade de volumosos investimentos para a recuperação do patamar estagnado há dez anos. Destaque especial é dado para a eficiência energética e, em menor grau, para as escalas dos processos produtivos adotados.

Analisando as informações fornecidas pelas empresas e as informações publicadas em trabalhos anteriores, verifica-se que não houve investimentos para a melhoria da eficiência energética do processo de síntese de amônia em todas as unidades estudadas neste trabalho.

As respostas das empresas em 1997 demonstram que os projetos de revamp citados por CEKINSKI et al. (1990) não foram realizados, pois ainda não existe, por exemplo, na unidade Piaçaguera,SP, o processo de recuperação de gás de purga. Nas unidades da PETROBRÁS, a afirmação de que os índices não mudaram em relação a 1985 negam a execução de qualquer projeto de revamp.

A conclusão a que se chega é que existe um potencial técnico de aumentar a eficiência energética dos processos de sintese de amônia e que os parâmetros obtidos em 1985 poderão ser empregados para o presente diagnóstico.

\subsubsection{Indicadores Técnicos do Processo de Producão de Amônia}

Algumas considerações a respeito dos valores de consumo de energia e de caracteristicas do processo de produção de amônia serão feitas a partir de agora com o objetivo de prosseguir com o diagnóstico. 
Os valores de consumo especifico global CEE G (tabela 3.8 ) para as unidades de fabricação de amônia no Brasil mostram que, na média, o resultado encontrado de 36,89 GJ/t amônia está cerca de $32 \%$ acima do valor possivel de ser atingido por unidades mais eficientes energeticamente. Quando se enfoca somente as três unidades que empregam o processo de reforma catalitica, atinge-se uma média de $\mathrm{CEE}_{\mathrm{G}}$ no valor de 35,47 GJ/t amônia, o que significa um consumo $26 \%$ maior de energia quando comparado a unidades que empregam a tecnologia de ponta, salientando-se que uma unidade eficiente e moderna é aquela cujo consumo de energia totaliza 28 GJ/t amônia.

Nas unidades a gás natural, Camaçari e Laranjeiras, os consumos específicos de energia são aqueles que mais se aproximam de $28 \mathrm{GJ} / \mathrm{t}$ amônia, pois já se beneficiam de medidas que visam a otimização do uso da energia. Laranjeiras já conta com pré aquecedor de ar para o reformador primário, aumentando assim a recuperação da entalpia dos gases liberados pela chaminé deste equipamento (BRUNO et al., 1985).

A unidade de Piaçaguera,SP, com processo de reforma com vapor (gás de refinaria) com indice de $37,5 \mathrm{GJ} / \mathrm{t}$ amônia, permite prever que há ainda um potencial de recuperação de energia a ser explorado, mesmo considerando que $28 \mathrm{GJ} / \mathrm{t}$ amônia seja uma meta arrojada pelo fato de tratarse de uma unidade de médio porte e relativamente antiga.

O quadro energético das unidades industriais do setor nitrogenados é apresentado no gráfico 3.9. São apresentadas as participações percentuais de entalpia de vapor, energia elétrica, combustivel e matéria-prima, em termos de equivalente energético com relação ao total de energia aplicada no setor. Constata-se que a matéria-prima responde pela maior parte da energia gasta no processamento da amônia. Os hidrocarbonetos de processo (matérias-primas) e os combustiveis representam $86,5 \%$ do total de energia aplicada. 
Gráfico 3.9. Porcentagem de participação dos insumos com relação ao consumo global do setor nitrogenados.

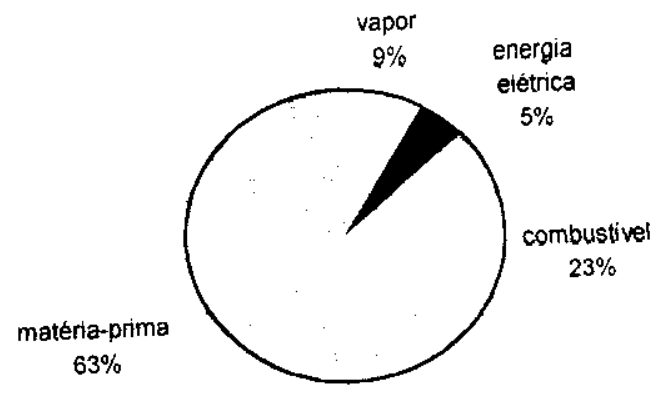

Fonte: BRUNO et al. (1985).

Outros insumos energéticos são utilizados no processo, porém em menor escala, como óleo combustivel, que é utilizado para geração de vapor no complexo amônia-uréia que produz amônia a partir de oxidação parcial de residuo asfáltico. Energia elétrica é necessária basicamente para o acionamento de equipamentos, tais como: ventiladores, compressores e sistemas de transporte. GLP e diesel apresentam utilização reduzida, restringindo-se a partidas e paradas de plantas e apoio à área de utilidades das diversas unidades.

0 consumo anual de gás natural, gás de refinaria e residuo asfáltico pode ser estimado de acordo com os dados fornecidos pela bibliografia e através dos questionários (tabela 3.10).

Tabela 3.10. Consumo de matérias-primas para a produção de amônia de acordo com a capacidade de produção (base: 330 dias por ano de funcionamento).

\begin{tabular}{|c|c|c|c|c|c|c|c|c|}
\hline Camaçari,BA & $\overline{G N}$ & 360.000 & 0,76 & 273.600 & 51,50 & 14.090 .400 & 13.244 .976 & 956.582 \\
\hline Laranjeiras,SE & GN & 330.000 & 0,69 & 227.700 & 46,68 & 10.629 .036 & 9.991 .294 & 744.024 \\
\hline Piaçaguera,SP & GR & 171.600 & 0,87 & 149.292 & 45,22 & 6.750 .984 & 6.345 .925 & 472.563 \\
\hline Araucária,PA & RASF & 396.000 & 0,89 & 352.440 & 39,52 & 13.928 .429 & 13.092 .723 & - \\
\hline
\end{tabular}

$1 \mathrm{j}=9,4^{\wedge} 10^{-4}$ btu

fonte: elaborado a partir de BRUNO et al. (1985) e ANDA (1996).

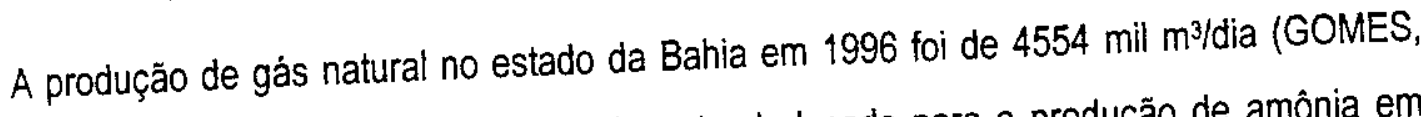
1996), o que significa que a quantidade de gás natural alocado para a produção de amônia em Camaçari,BA (tabela 3.10 ) é equivalente a $21 \%$ da produção estadual. 
O estado de Sergipe, em 1996, produziu 1873 mil m³/dia de gás natural (GOMES, 1996), sendo que $39,7 \%$ da produção foi destinada à unidade de amônia de Laranjeiras,SE (tabela 3.10).

A análise acima permitiu reconhecer a quantidade consumida de gás natural na indústria de amônia e fertilizantes nos estados. Comparando agora o consumo de gás natural na indústria de amônia com a produção nacional de 24 milhões m³/dia, em 1996 (GOMES, 1996), a participação passa a ser de $7,08 \%$ do total produzido.

Considerando-se que aproximadamente $35 \%$ do gás natural produzido no Brasil ou é reinjetado ou queimado sem aproveitamento, a oferta real passa a ser de 15,6 milhões $\mathrm{m}^{3} / \mathrm{dia}$ e a proporção utilizada para a produção de amônia se eleva para $11 \%$.

As observações posteriores indicaram a importância do setor na demanda por este hidrocarboneto. Verificou-se que, levando em conta somente as unidades que utilizam gás natural, o papel da indústria de amônia não é desprezivel na formação da matriz energética brasileira. É necessário, também, dizer que a participação do gás natural na matriz energética do Brasil é de apenas $2,5 \%$ (GOMES, 1996).

\subsubsection{Importância da Amônia na Produção de FMN}

No processo de fabricação dos fertilizantes também è a matéria-prima (amônia) a responsável pelo maior dispêndio energético (gráfico 3.10). Buscar melhorar a eficiência energética de produção de amônia pode, então, provocar efeitos positivos no requerimento energético para a produção dos fertilizantes nitrogenados.

Gráfico 3.10. Consumos especificos de energia por tonelada de produto para a produção de fertilizantes nitrogenados simples (fonte BRUNO et al, 1985).

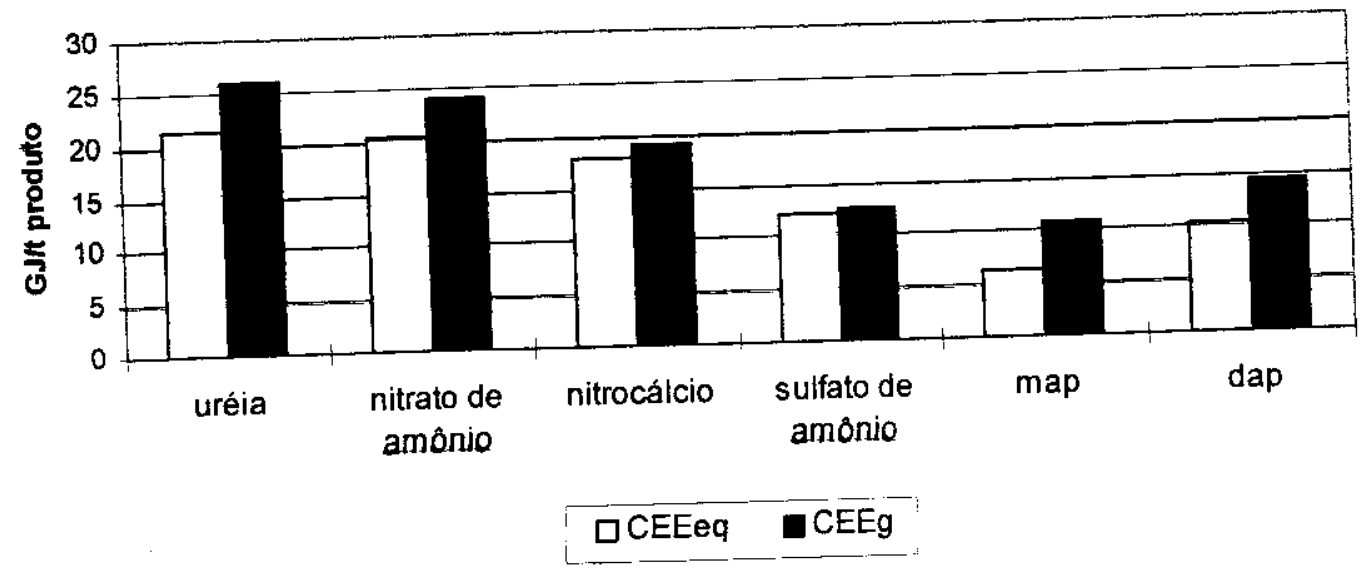


0 gráfico 3.11 foi construido para ilustrar a quantidade de energia gasta na produção dos fertilizantes, porém, de acordo com a concentração de nitrogênio de cada um. 0 que se observa é que a uréia passa a ser 0 fertilizante nitrogenado de menor valor energético por tonelada de nitrogênio, porque apresenta a maior concentração deste nutriente por tonelada do produto fertilizante.

Gráfico 3.11. Consumos especificos de energia por tonelada de nitrogênio, para produção de fertilizantes nitrogenados simples.

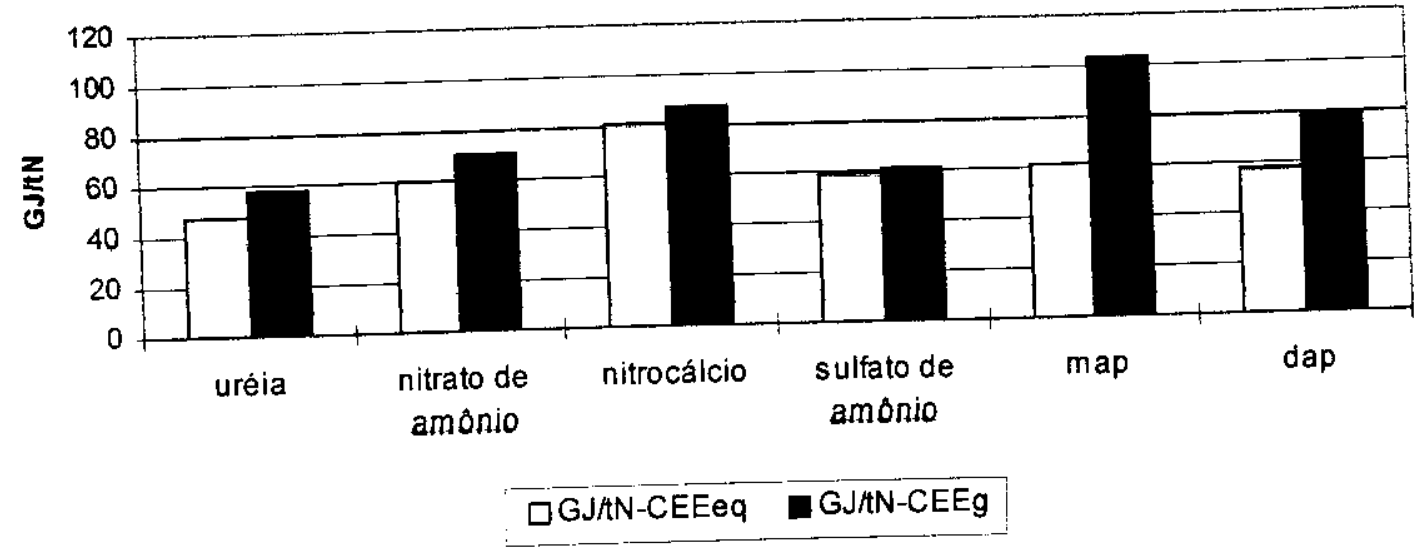

fonte: elaborado a partir de BRUNO et al. (1985).

\subsection{Potencial de Conservacão de Energia}

Parte considerảvel do consumo de energia primária na sociedade moderna esta conectado à produção de materiais de base como aço e químicos (WORREL \& BEER, 1995). Custos com energia representam uma grande parcela dos custos de produção destas indústrias, o que torna atraente investimentos em conservação de energia. Outra característica que favorece 0 interesse pelo uso eficiente de energia é a existência de uma estreita margem de lucro nestes setores.

A produção de amônia mundial apresenta um potencial de elevar sua eficiência energética, porque, da capacidade total em 1991 (ao redor de 152,9 milhões de toneladas), apenas $12 \%$ eram de unidades com cinco anos ou menos de implantação, $68 \%$ tinham sido construídas há dez anos ou mais e $20 \%$ há quinze anos ou mais, quando consideradas as unidades instaladas antes de 1971. Aproximadamente 25,4 Mtoneladas de amônia são provenientes de plantas construidas antes de 1971 e ainda em operação. 
A idade da unidades reflete o grau de desenvolvimento tecnológico referente ao consumo de energia necessário para a sintese da amônia. Isto é, quando comparadas aos novos projetos, 0 consumo de energia por tonelada de amônia destas unidades antigas está 20 a $40 \%$ acima, caracterizando um processo menos eficiente energética e economicamente.

Este acontecimento é justificado quando se analisa a situação do mercado na última década, que não apresentou um quadro favorável. Muitas companhias abandonaram o negócio ou pensaram em fazê-lo. A tendência de companhias estatais de exportar a qualquer preço, a constatação da existência de um excesso de oferta do produto no mercado mundial e a diminuição de consumo de fertilizantes nos paises industrializados em consequência de problemas ambientais são fatores apontados como causa da não construção de novas unidades de amônia nos últimos anos (NITROGEN, 1984).

O que tem ocorrido é a procura dos produtores de amônia por possibilidades do que se denomina revamp ou modernização de suas unidades antigas e menos eficientes para se tornarem competitivas. $O$ objetivo desta modernização pode ser aumentar a eficiência energética elou aumentar a capacidade de produção ou methora da confiabilidade da unidade. Existe, contudo, um limite para o nivel de energia a ser conservada que pode ser economicamente justificado, porque a introdução das medidas de conservação de energia pode representar uma quase substituição da unidade antiga. MULCKHUYSE \& VENKATARAMAN (1985) relatam que o limite máximo economicamente viável para a conservação de energia através de revamp em unidades de $1000 \mathrm{t}$ $\mathrm{NH}_{3} /$ dia, apresentando condições ótimas de operação, é ao redor de $20 \%$. Este valor é menor para unidades menores.

Possibilidades de revamp têm sido demonstradas pelos cinco atuais licenciadores da tecnologia de produção de amônia: Braun (atualmente Brown \& Root Braun), Imperial Chemical Industries Ldt. (ICI), M.W. Kellogg Co., Haldor Topsoe AVS e Udhe GmbH. Estes projetos podem resultar em uma planta de amónia de baixo consumo de energia, consumindo aproximadamente 28 $\mathrm{GJ} / \mathrm{t} \mathrm{NH}$, que é o valor mínimo alcançado na atualidade pelos novos projetos desenvolvidos pelas licenciadoras.

Outra vantagem de efetuar-se o revamp está relacionada ao investimento necessário: cerca de três a quatro vezes menor, por tonelada de amônia, do que o investimento em uma nova unidade (ÁVILA, 1997). 
HONTI (1981) analisou as op̧̧ões de conservação de energia no processo de sintese de amônia através de instrumentos baseados na primeira lei da termodinâmica: um diagrama de fluxo de energia total e a representação numérica das perdas de trabalho nas diferentes etapas do processo (tabela 3.11). 0 diagrama do balanço total de energia identifica a etapa de produção do gás de sintese como fase onde ocorrem as maiores perdas de calor, sendo as perdas por compressão as mais significativas. A tabela 3.11 permite detectar o pré-aquecimento e 0 reformador primário representando $55 \%$ da perda total de trabalho na unidade de amônia.

Tabela 3.11. Perda de trabalho em uma unidade de sintese de amônia pelo processo de reforma com vapor d'água utilizando gás natural como matéria -prima.

\begin{tabular}{ccc}
\hline etapa do processo & $\begin{array}{c}\text { perda de } \\
\text { trabalho GJ/t }\end{array}$ & $\begin{array}{c}\text { \% em função do } \\
\text { trabalho total perdido } \\
\text { na unidade }\end{array}$ \\
\hline $\begin{array}{c}\text { pré-aquecimento e reformador primário } \\
\text { compressão de ar no reformador secundário e e waste } \\
\text { heat boiler" }\end{array}$ & 10,17 & 55,0 \\
formação de $\mathrm{CO}_{2}$ (alta e baixa temperatura) e & 2,55 & 13,7 \\
metanação & 0,54 & 3,1 \\
remoção de $\mathrm{CO}_{2}$ & & \\
compressão e sintese & 1,09 & 6,1 \\
refrigeração & 1,55 & 8,4 \\
sistema de vapor & 0,12 & 0,8 \\
perdas gerais & 1,55 & 8,4 \\
\hline total & 0,84 & 4,5 \\
\hline
\end{tabular}

fonte: HONTI (1981).

HONTI (1981) argumenta, entretanto, que tais representações são incompletas porque não consideram a degradação da energia; mas avalia que somente a análise exergética também é incompleta, uma vez que demonstra um potencial de conservação superestimado.

A definição de exergia da amônia é a demanda minima teórica de energia para produção de amônia, sem considerar o tipo de processo, equivalente ao trabalho químico (energia disponivel, componente transformável da energia) que pode ser obtido quando a amônia é convertida nas matérias-primas abundantes na natureza: água liquida e nitrogênio do ar (BEER et al., 1995).

A análise exergética (tabela 3.12) de uma unidade moderna de amônia $\left(29,3 \mathrm{GJ} / \mathrm{t} \mathrm{NH}_{3}\right)$ aponta o reformador primário e a geração de vapor como representando $70 \%$ das perdas exergéticas devido às irreversibilidades no processo de combustão. As perdas na fase de sintese 
de amônia representam $15 \%$ do total, causadas principalmente pelo resfriamento entre os leitos catalíticos (BEER et al., 1995).

A tabela permite, também, comparar os balanços exergético e de entalpia, apresentando as diferenças relacionadas aos processos de maior representatividade com relação à perdas e possiveis melhoras de eficiência nos processos.

$O$ balanço de entalpia, contrariamente à análise exergética, não demonstra o reformador primário e a geração de vapor como os locais de maiores perdas, mas as perdas na turbina, representando $60 \%$ do total.

Tabela 3.12. Balanço energético e exergético de uma unidade moderna de amônia* $\left(G J / t \mathrm{NH}_{3}\right)$.

\begin{tabular}{|c|c|c|c|c|c|}
\hline input & $\begin{array}{c}\text { poder } \\
\text { calorífico } \\
\text { superior }\end{array}$ & exergla & output & $\begin{array}{c}\text { poder } \\
\text { calorífico } \\
\text { superior } \\
\end{array}$ & exergia \\
\hline $\begin{array}{l}\text { consumo total de gás } \\
\text { natural } \\
\text { matéria-prima } \\
\text { p/reformador } \\
\text { combustivel } \\
\text { pireformador } \\
\text { combustivel p/ caldeira } \\
\text { auxiliar }\end{array}$ & $\begin{array}{r}32,6 \\
24,6 \\
7,49 \\
0,33\end{array}$ & $\begin{array}{l}30,7 \\
23,3 \\
7,07 \\
0,33\end{array}$ & $\begin{array}{c}\text { perdas totais } \\
\text { reforma } \\
\text { geração de vapor } \\
\text { shift + } \mathrm{CO}_{2}+\text { metanação } \\
\text { sintese de amônia } \\
\text { turbina + compressor } \\
\text { outras perdas } \\
\text { stack } \\
\text { energia na } \\
\text { amônia }\left(-33^{\circ} \mathrm{C}\right) \\
\text { output total }\end{array}$ & $\begin{array}{l}1,30 \\
\\
1,72 \\
6,53 \\
0,33 \\
0,96 \\
21,0 \\
32,5\end{array}$ & $\begin{array}{l}10,5 \\
4,94 \\
2,38 \\
0,67 \\
1,55 \\
0,54 \\
0,21 \\
0,25 \\
20,1 \\
\\
30,7 \\
\end{array}$ \\
\hline
\end{tabular}

fonte: BEER et al. (1995).

* $29,3 \mathrm{GJ} / \mathrm{t} \mathrm{NH}_{3}$

Para finalizar, o quadro a seguir sintetiza as principais etapas do processo de sintese de amônia por reforma com vapor que são consideradas pela bibliografia especializada como passiveis de serem modificadas através de revamp. 
Quadro 3.2. Medidas de conservação de energia propostas para a indústria de amônia.

\begin{tabular}{|c|c|c|c|}
\hline autor & $\begin{array}{l}\text { etapa do } \\
\text { processo }\end{array}$ & modificação & observaçōes \\
\hline $\begin{array}{c}\text { MULCKHUYSE \& } \\
\text { VENKATARAMAN } \\
\text { (1985), BRUNO et al. } \\
(1985) \text { e ÁVILA } \\
(1998)^{6}\end{array}$ & $\begin{array}{l}\text { reformador } \\
\text { primário }\end{array}$ & $\begin{array}{l}\text { Recuperação de calor resultante da combustão } \\
\text { na fornalha do reformador primário para pré } \\
\text { aquecimenta do ar de combustão. }\end{array}$ & $\begin{array}{l}\text { Aumento na eficiência de combustão de } 20 \% \text {. } \\
\text { Requer baixo investimento em nova unidade e alto } \\
\text { em unidade já em funcionamento. Economia de } \\
0,8 \text { a } 1,2 \mathrm{GJ} / \mathrm{NH} \mathrm{NH}_{3} \text {. }\end{array}$ \\
\hline $\begin{array}{c}\text { WORRELL \& BEER } \\
(1995) \\
\text { ÁVILA (1998) }\end{array}$ & $\begin{array}{l}\text { reformador } \\
\text { primário }\end{array}$ & $\begin{array}{l}\text { Instalação de um pré-reformador aquecido pelo } \\
\text { calor produzido no reformador primário. Faz com } \\
\text { que o gás natural seja parciaimente convertido } \\
\text { em gás de sintese utilizando catalisadores } \\
\text { altamente ativos }\end{array}$ & $\begin{array}{l}\text { Redução na produção de excesso de vapor na } \\
\text { zona de convecção do reformador primário, } \\
\text { diminuindo sua carga térmica. Implantado } \\
\text { geralmente em unidades que utilizam nafta. } \\
\text { Economia de } 1,6 \mathrm{GJ} / \mathrm{tNH}_{3} \text {. }\end{array}$ \\
\hline BRUNO et al. (1985) & $\begin{array}{l}\text { reformador } \\
\text { primário }\end{array}$ & $\begin{array}{l}\text { Geração de vapor a partir do calor rejeitado na } \\
\text { etapa de reforma para movimentar as turbinas } \\
\text { dos compressores. }\end{array}$ & $\begin{array}{l}\text { O vapor de exaustão das turbinas deve estar em } \\
\text { uma pressão suficiente para suprir as } \\
\text { necessidades do reformador primário. }\end{array}$ \\
\hline $\begin{array}{l}\text { MULCKHUYSE \& } \\
\text { VENKATARAMAN } \\
(1985) \\
\text { ÁVILA (1998) } \\
\text { JARVAN (1989) }\end{array}$ & $\begin{array}{l}\text { sintese de } \\
\text { amônia }\end{array}$ & $\begin{array}{l}\text { Revamp do reator de sintese, passando de } \\
\text { fluxo axial para radial. }\end{array}$ & $\begin{array}{l}\text { Existe alta queda de pressão ao longo dos } \\
\text { reatores com fluxo axial e baixa conversão per } \\
\text { pass. Os reatores com fluxo radial demonstram } \\
\text { baixa queda de pressão e alta taxa de conversão } \\
\text { pelo uso de partículas menores de catalisadores } \\
\text { Ecanomia de } 0,7 \mathrm{GJ} / \mathrm{NH}_{3} \text {. }\end{array}$ \\
\hline $\begin{array}{l}\text { MULCKHUYSE \& } \\
\text { VENKATARAMAN }\end{array}$ & $\begin{array}{l}\text { síntese de } \\
\text { amônia }\end{array}$ & $\begin{array}{l}\text { Instalação de um conversor de amônia } \\
\text { adicional, em paralelo com o existente. }\end{array}$ & $\begin{array}{l}\text { Economiza reciclo do gás, energia para } \\
\text { compressão de refrigeração e "desengargala" o } \\
\text { loop de sintese. Economia de } 1,12 \mathrm{GJ}_{\mathrm{t} N \mathrm{NH}_{3}} \text {. }\end{array}$ \\
\hline
\end{tabular}

- comunicação pessoal: Paulo Avila, da PETROBRÁS - Camaçari,BA, via e-mail, abril de 1998.

50 
Quadro 3.2. Continuação.

\begin{tabular}{|c|c|c|c|}
\hline autor & $\begin{array}{l}\text { etapa do } \\
\text { processo }\end{array}$ & modificação & observações \\
\hline $\begin{array}{l}\text { WORRELL \& BEER } \\
\text { (1995), FINN (1988) e } \\
\text { MULCKHUYSE \& } \\
\text { VENKATARAMAN } \\
(1985)\end{array}$ & gás de purga & $\begin{array}{l}\text { Recuperação de hidrogênio do gás de purga } \\
\text { através de instalação de membranas ou } \\
\text { unidade criogênica. }\end{array}$ & $\begin{array}{l}\text { Gás de purga equivale a } 4 \text { - } 6 \% \text { do fluxo total de gás } \\
\text { de sintese e contém considerável quántidade de } \\
\text { hidrogênio e amônia. Economia de } 0,7 \text { a } 1,8 \mathrm{GJ} / \mathrm{t} \\
\mathrm{NH}_{3} \text {. }\end{array}$ \\
\hline $\begin{array}{l}\text { MULCKHUYSE \& } \\
\text { VENKATARAMAN } \\
\text { (1985) }\end{array}$ & $\begin{array}{l}\text { unidade de } \\
\text { amônia }\end{array}$ & $\begin{array}{l}\text { Melhorar ou implementar um esquema de } \\
\text { gestão para adquirir conhecimento da } \\
\text { performance dos equipamentos. }\end{array}$ & \\
\hline $\begin{array}{c}\text { HONTI (1981) e } \\
\text { BRUNO et al,(1985) }\end{array}$ & $\begin{array}{l}\text { compressão e } \\
\text { expansão de } \\
\text { vapor }\end{array}$ & $\begin{array}{l}\text { Aumentar a eficiência energética de } \\
\text { compressores e turbinas. }\end{array}$ & $\begin{array}{l}\text { Perto de } 20 \% \text { do total de energia consumida para } \\
\text { produção de amônia é para compressão. Economia } \\
\text { de } 0,8 \text { a } 1,0 \mathrm{GJ} / \mathrm{t} \mathrm{N} \text {. }\end{array}$ \\
\hline $\begin{array}{c}\text { WORRELL \& BEER } \\
(1995) \\
\text { HONTI ( 1981) }\end{array}$ & $\begin{array}{l}\text { rede de troca } \\
\text { de calor }\end{array}$ & $\begin{array}{l}\text { Integração da rede de troca de calor para } \\
\text { utilizar o calor residual. }\end{array}$ & Econamia de 1,6 GJit $\mathrm{NH}_{3}$ \\
\hline $\begin{array}{l}\text { BEER et al. (1995) } \\
\text { ZARDI \& ANTONINI } \\
\quad(1979)\end{array}$ & $\begin{array}{l}\text { reformador } \\
\text { secundário }\end{array}$ & $\begin{array}{l}\text { Utilização de excesso de ar. Quantidade } \\
\text { maior de metano sai do reformador primário } \\
\text { e é convertido no reformador secundário pelo } \\
\text { ar em excesso. }\end{array}$ & $\begin{array}{l}\text { Comparado ao processo convencional, uma maior } \\
\text { parte da corrente de gases reage no reformacior } \\
\text { secundário por aquecimento direto (mais eficiente) } \\
\text { do que no reformador primário por aquecimerito } \\
\text { indirelo (menos eficiente). }\end{array}$ \\
\hline
\end{tabular}




\subsection{Análise Econômico-financeira das Possibilidades de Conservação de Energia na Indústria de Amônia}

\subsubsection{Metodologia}

O estudo das possibilidades de redução do consumo energético nas unidades brasileiras produtoras de amônia baseou-se nos itens anteriores: Potencial de Conservação de Energia e Diagnóstico da Indústria Brasileira de Amônia. O presente item pretende indicar a viabilidade de aumentar a eficiência energética deste setor através da avaliação do custo das modificações tecnológicas identificadas como possiveis de serem efetuadas.

Vale ressaltar que esta análise tem caráter estritamente demonstrativo, pois um revamp real necessita de uma auditoria energética da unidade para se obter informações detalhadas de consumo de energia, desempenho dos equipamentos ao longo de todo o processo, e principaimente dos custos especificos de cada modificação.

Como para este exercício/estudo não foi efetuada uma auditoria energética, os dados aqui empregados, tanto de custo como do potencial de conservação de energia, foram obtidos através da bibliografia especializada e por intermédio das empresas nacionais produtoras de amônia e das empresas detentoras da tecnologia de sintese de amônia.

Isto significa que o objetivo dos resultados é de apresentar somente um panorama indicativo do que se apresenta viável em termos de opções de rotas de produção energeticamente mais eficientes.

A análise econômico-financeira foi efetuada utilizando como ferramentas as figuras de mérito desenvolvidas a partir da engenharia econômica e de análise de projetos. A figura de mérito empregada é denominada CEC (Custo da Energia Conservada), que permite comparar investimentos em eficiência energética com custos da energia na forma de matéria-prima e combustivel.

O CEC determina o custo por unidade de energia conservada resultante da instalação do novo equipamento ou da adoção da nova tecnologia.

$C E C=\frac{C C V A}{\text { energia conservada }} \quad$ (equaçāo I)
$C E C=U S \$ / G J$


Por sua vez, CCVA - Custo do Ciclo de Vida Anualizado - é o custo anual requerido para o pagamento total do investimento ao longo de sua vida útil, acrescido dos custos anuais de operação e manutenção.

$C C V A=I_{0}{ }^{*} F R C+O \& M \quad$ (equação II)

onde:

$I_{0}$ - investimento inicial (US\$)

O\&M - custos anuais de operação e manutenção (US\$)

Fator de Recuperação de Capital - FRC é o indice pelo qual o investimento total do projeto é recuperado anualmente em função de uma determinada taxa de desconto, dentro do seu período de vida útil.

$$
F R C=\frac{i}{\left[1-(1+i)^{-N}\right]} \text { ou } \quad F R C=\frac{i(1+i)^{N}}{(1+i)^{N}-1} \text { (eqijacão liit) }
$$

onde:

FRC - fator de recuperaçāo de capital

\section{i - taxa de desconto (\% ao ano)}

$N$ - vida útil do equipamento (anos)

A taxa de desconto é 0 indice peio qual se estima 0 valor presente de determinada quantidade de moeda no futuro. A escotha da taxa de desconto deve considerar as taxas de mercado variáveis conforme os termos de contrato de crédito. Para a análise empregaram-se três taxas de desconto: 10,12 e $15 \%$ ao ano.

Considerou-se que não existirá acréscimo nos custos de operação e manutenção devido às mudanças no processo, portanto, na análise, eles estão definidos como nulos.

Os custos de manutenção apresentam uma dificuldade em ser divididos exatamente para cada parte da unidade, além de ser também dificil dividi-los por unidade de um complexo de plantas, panorama comum nas indústrias de fertilizantes. O que se faz, então, de acordo com ẢVILA (1998), é ratear os custos entre as unidades e, na unidade, entre as etapas do processo. Por causa deste grau de dificuldade, não foi possivel obter estes dados nas empresas. 
A única informação recebida com relação aos custos varáveis foi de caráter qualitativo: LYSE-PETERSEN (1998) ${ }^{7}$ indicou que a instalação de recuperação criogênica de gás de purga e do pré-aquecimento do gás de combustão refletem na elevação dos custos de manutenção. A modificação no reator de sintese, em compensação, não provoca modificações neste custo.

\subsubsection{Resultados}

O quadro e a tabela a seguir mostram as opções de revamp definidas para cada unidade estudada, seu respectivo potencial de conservar energia e o efeito no consumo de energia total para a produção de amônia por tonelada do produto.

Quadro 3.3. Modificações propostas para as unidades de amônia brasileiras.

\begin{tabular}{|c|c|}
\hline tecnologia & economia de energia \\
\hline $\begin{array}{c}\text { Instalação de pré-aquecimento do } \\
\text { ar de combustäo na fornalha do } \\
\text { reformador primário }\end{array}$ & $\begin{array}{c}\text { Implementado para recuperar as perdas de calor provenientes da } \\
\text { combustäo, reduzindo a carga térmica do reformador primário. Resulta } \\
\text { em economia de combustivel. }\end{array}$ \\
\hline $\begin{array}{c}\text { Reator de sintese: troca dos } \\
\text { internos, passando de fluxo axial } \\
\text { para radial }\end{array}$ & $\begin{array}{c}\text { Uma maior taxa de conversão de amónia ao longo do reator leva a uma } \\
\text { reducão da necessidade de gás circulando no loop de sintese. Reduz o } \\
\text { consumo de energia para compressäo de reciclo e refrigeracão. }\end{array}$ \\
\hline $\begin{array}{c}\text { Instalação de unidade recuperadora } \\
\text { de gás de purga }\end{array}$ & $\begin{array}{c}\text { Como o objetivo da reforma com vapor d'água de hidrocarbonetos é } \\
\text { obter hidrogénio, recuperá-lo do gás de purga e reciclá-lo ao processo } \\
\text { resulta em economia de combustivele e matéria-prima. }\end{array}$ \\
\hline
\end{tabular}

Tabela 3.13. Medidas de conservação de energia para unidades de amônia e o efeito no consumo de energia.

\begin{tabular}{|c|c|c|c|c|c|c|c|c|}
\hline \multirow[b]{2}{*}{ unidades } & consumd & \multicolumn{5}{|c|}{ potencial de conservação GJ/t amônia } & \multirow{2}{*}{$\begin{array}{r}\text { consumo } \\
\text { com } \\
\text { medidas } \\
\text { GJ/tamônia }\end{array}$} & \multirow{2}{*}{$\begin{array}{r}\% \\
\text { economizada } \\
\text { de energia }\end{array}$} \\
\hline & $\begin{array}{r}\text { atual } \\
G J / \\
\text { amônia }\end{array}$ & $\begin{array}{r}\text { gás de } \\
\text { purga } \\
\text { criogênica }\end{array}$ & $\begin{array}{r}\text { gás de } \\
\text { purga } \\
\text { membranas }\end{array}$ & $\begin{array}{r}\text { reator } \\
d e \\
\text { sintese }\end{array}$ & aquecimento & aquecimentd & & \\
\hline Camaçari & 34,66 & 1,0 & 0 & 0,7 & 0,8 & 0 & 32,16 & 7,2 \\
\hline Laranjeiras & 34,27 & 1,0 & 0 & 0,7 & 0 & 0 & 32,57 & 4, \\
\hline Piaçaguera & 37,49 & $\underline{0}$ & 0,7 & 0 & $\underline{0}$ & 0,8 & 35,99 & 4,0 \\
\hline Araucária & 41,17 & 0 & 0 & 0 & 0 & 0 & 41,17 & 0,0 \\
\hline
\end{tabular}

${ }^{7}$ comunicação pessoal: Svend Erik Lyse-Petersen, da empresa Haldor Topsoe, Dinamarca, através de e-mail, junho de 1998. 
Tabela 3.13. Continuação.

\begin{tabular}{|l|c|c|c|c|c|c|c|c|}
\hline anualmente & consumido & \multicolumn{10}{|c|}{ economizado } \\
\cline { 2 - 10 } & GJ & $G J$ & $G J$ & $G J$ & $G J$ & $G J$ & total GJ & $\%$ econ. \\
\hline Camaçari & 12.477 .600 & 360.000 & 0 & 252.000 & 288.000 & 0 & 11.577 .600 & 7,2 \\
\hline Laranjeiras & 11.309 .100 & 330.000 & 0 & 231.000 & 0 & 0 & 10.748 .100 & 4,9 \\
\hline Piaçaguera & 6.433 .284 & 0 & 120.120 & & 0 & 137.280 & 6.175 .884 & 4,0 \\
\hline Araucária & 16.303 .320 & 0 & 0 & 0 & 0 & 0 & 16.303 .320 & 0,0 \\
\hline total & 46.523 .304 & 690.000 & 120.120 & 483.000 & 288.000 & 137.280 & 44.804 .904 & 3,7 \\
\hline
\end{tabular}

A instalação do pré-aquecedor de ar de fornalha foi uma opção considerada na análise, apesar de requerer altos investimentos em uma unidade já em funcionamento por causa da necessidade de instalação de alguns equipamentos e da alteração na estratégia de controle operacional e de segurança do formo (ÁVILA, 1998). Somente as unidades de amônia de Piaçaguera,SP e Camaçari,BA foram indicadas para utilização desta tecnologia porque na unidade de Laranjeiras, SE já existe o pré-aquecimento do gás de combustão.

No que diz respeito às tecnologias de recuperação de gás de purga, as três unidades apresentam possibilidades de adotá-las. De acordo com LYSE-PETERSEN (1998), para a unidade de Piaçaguera,SP a tecnologia indicada de recuperação de gás de purga é através de membranas permeáveis por demandar menor investimento. A desvantagem em relação à tecnologia de recuperação criogênica é a menor recuperação de hidrogênio. A opção indicada é uma membrana resistente à amônia no estado gasoso, evitando a implementação de um sistema de pré-tratamento para remoção desta (ÁVlLA, 1998).

Para unidades de amônia maiores, como Camaçari, BA e Laranjeiras, SE, LYSEPETERSEN (1998) indica a tecnologia de recuperação criogênica do gás de purga, que separa os gases por destilação. Como mencionado, requer um investimento maior do que a outra tecnologia, porém recupera maior quantidade de hidrogênio além de economizar recompressão do hidrogênio, pois este è recuperado a alta pressão.

A tecnologia criogênica apresenta também uma vantagem de caráter ambiental se comparada à tecnologia de membranas: a amônia será adicionada ao off gas na tecnologia de membranas, elevando o conteúdo de óxidos de nitrogênio no gás de combustão do reformador primário (LYSE-PETERSEN, 1998).

A opção escolhida para a modificação no reator de sintese é denominada modificação insitu (JARVAN, 1989). A unidade de Piaçaguera,SP não foi indicada para este revamp pelo fato de ser uma unidade com menor capacidade de produção ( $520 \mathrm{t} / d i a)$, o que reflete em elevação dos 
custos. $E$, também, em consequência de sua idade (1970), fator que toma as opções em conservação de energia muitas vezes incompativeis pelas diferenças de concepções nos projetos atuais com relação às antigas unidades.

Caso as modificações propostas fossem efetuadas, observa-se na tabela 3.13 que as unidades de Camaçari,BA e Laranjeiras,SE atingiriam valores de consumo de energia 15 e 16\%, respectivamente, acima do minimo atual de $28 \mathrm{GJ} / \mathrm{t}$ amônia. A unidade de Piaçaguera,SP atingiria uma economia de $4 \%$ em relação ao valor atual.

A nova média brasileira de consumo de energia para produção de amônia, considerando a unidade de Araucária,PA, seria 35,47 GJ/t amônia contra os 36,89 GJ/t atuais.

A seguir, são apresentados os resultados dos cálculos do CEC para as medidas de conservação de energia definidas nas unidades de amônia: Camaçari,BA; Laranjeiras,SE e Piaçaguera,SP. Os cálculos detalhados estão demonstrados no ANEXO 3.

Tabela 3.14. CEC da modificação no reator de sintese, unidade Camaçari e Laranjeiras.

\begin{tabular}{|r|r|r|}
\hline taxa de desconto & U\$/GJ economizado & $\begin{array}{r}\text { U\$/milhāo Btu } \\
\text { economizado }\end{array}$ \\
\hline $10 \%$ & 0,79 & 0,84 \\
\hline $12 \%$ & 0,90 & 0,95 \\
\hline $15 \%$ & 1,08 & 1,14 \\
\hline
\end{tabular}

Tabela 3.15. CEC da instalação do recuperador de gás de purga por membranas, unidade de Piaçaguera.

\begin{tabular}{|r|r|r|}
\hline taxa de desconto & US\$/GJ economizado & $\begin{array}{r}\text { US/milhão Btu } \\
\text { economizado }\end{array}$ \\
\hline $10 \%$ & 1,76 & 1,85 \\
\hline $12 \%$ & 1,91 & 2,01 \\
\hline $15 \%$ & 2,15 & 2,27 \\
\hline
\end{tabular}

Tabela 3.16. CEC da instalação do recuperador de gás de purga, criogênica, unidade de Camaçari e Laranjeiras.

\begin{tabular}{|r|r|r|}
\hline taxa de desconto & U\$/GJ economizado & $\begin{array}{r}\text { U\$/milhão Btu } \\
\text { economizado }\end{array}$ \\
\hline $10 \%$ & 1,95 & 2,06 \\
\hline $12 \%$ & 2,12 & 2,24 \\
\hline $15 \%$ & 2,39 & 2,52 \\
\hline
\end{tabular}


Tabela 3.17. CEC da instalação do pré-aquecimento do gás de combustão, unidade Piaçaguera.

\begin{tabular}{|r|r|r|}
\hline taxa de desconto & U\$/GJ economizado & $\begin{array}{r}\text { U\$/milhāo Btu } \\
\text { economizado }\end{array}$ \\
\hline $10 \%$ & 2,16 & 2,27 \\
\hline $12 \%$ & 2,46 & 2,59 \\
\hline $15 \%$ & 2,93 & 3,09 \\
\hline
\end{tabular}

Tabela 3.18. CEC da instalação do pré-aquecimento do gás de combustão, unidade de Camaçari.

\begin{tabular}{|r|r|r|}
\hline taxa de desconto & U\$/GJ economizado & $\begin{array}{r}\text { U\$/milhão Btu } \\
\text { economizado }\end{array}$ \\
\hline $10 \%$ & 1,41 & 1,49 \\
\hline $12 \%$ & 1,61 & 1,69 \\
\hline $15 \%$ & 1,92 & 2,02 \\
\hline
\end{tabular}

\subsubsection{Discussão: Curva Cumulativa de Recursos}

Como foi mencionado anteriormente, o CEC deve ser comparado ao custo da energia, neste caso, referenta aos hidrocarbonetos empregados como matéria-prima e combustivel. A tabela 3.19 fornece os preços obtidos de diferentes fontes. Decidiu-se utilizar a média dos dados para a comparação.

Tabela 3.19. Preço do gás natural e gás de refinaria.

\begin{tabular}{|r|r|r|}
\hline finalidade & US\$ / GJ & US\$ / milhão Btu \\
\hline fins combustiveis & $2,08^{\mathrm{a}}$ & $2,20^{\mathrm{a}}$ \\
\hline " & $2,26^{\mathrm{b}}$ & $2,39^{\mathrm{b}}$ \\
\hline " & $3,41^{\mathrm{c}}$ & $3,60^{\mathrm{c}}$ \\
\hline " & $2,92^{\mathrm{d}}$ & $3,09^{\mathrm{d}}$ \\
\hline média & 2,67 & 2,82 \\
\hline fins petroquimicos & $1,61^{\mathrm{a}}$ & $1,70^{\mathrm{a}}$ \\
\hline " & $1,48^{\mathrm{b}}$ & $1,57^{\mathrm{b}}$ \\
\hline " & $1,44^{\mathrm{d}}$ & $1,52^{\mathrm{d}}$ \\
\hline média & 1,51 & 1,60 \\
\hline gás de refinaria & $1,15^{\mathrm{e}}$ & $1,22^{\mathrm{e}}$ \\
\hline média & 1,15 & 1,22 \\
\hline
\end{tabular}

a: RAPPEL \& LOIOLA (1993).

: Agência para Aplicação de Energia (1995) - comunicação pessoal.

c: Balanço Energético Nacional (1997).

d. ABIQUIM (1996), preço do gás para fins combustiveis sem contar US $\$ 1,00$ de frete.

e: GOMES (1996). 
Utilizando os dados do potencial de conservação de energia e o custo por GJ economizado com as modificações propostas ao processo de fabricação de amônia, foi possivel construir curvas cumulativas do potencial total de economia de energia versus o custo de cada alternativa.

Gráfico 3.13. Curva do potencial de conservação de energia em função do custo por GJ de cada medida proposta.

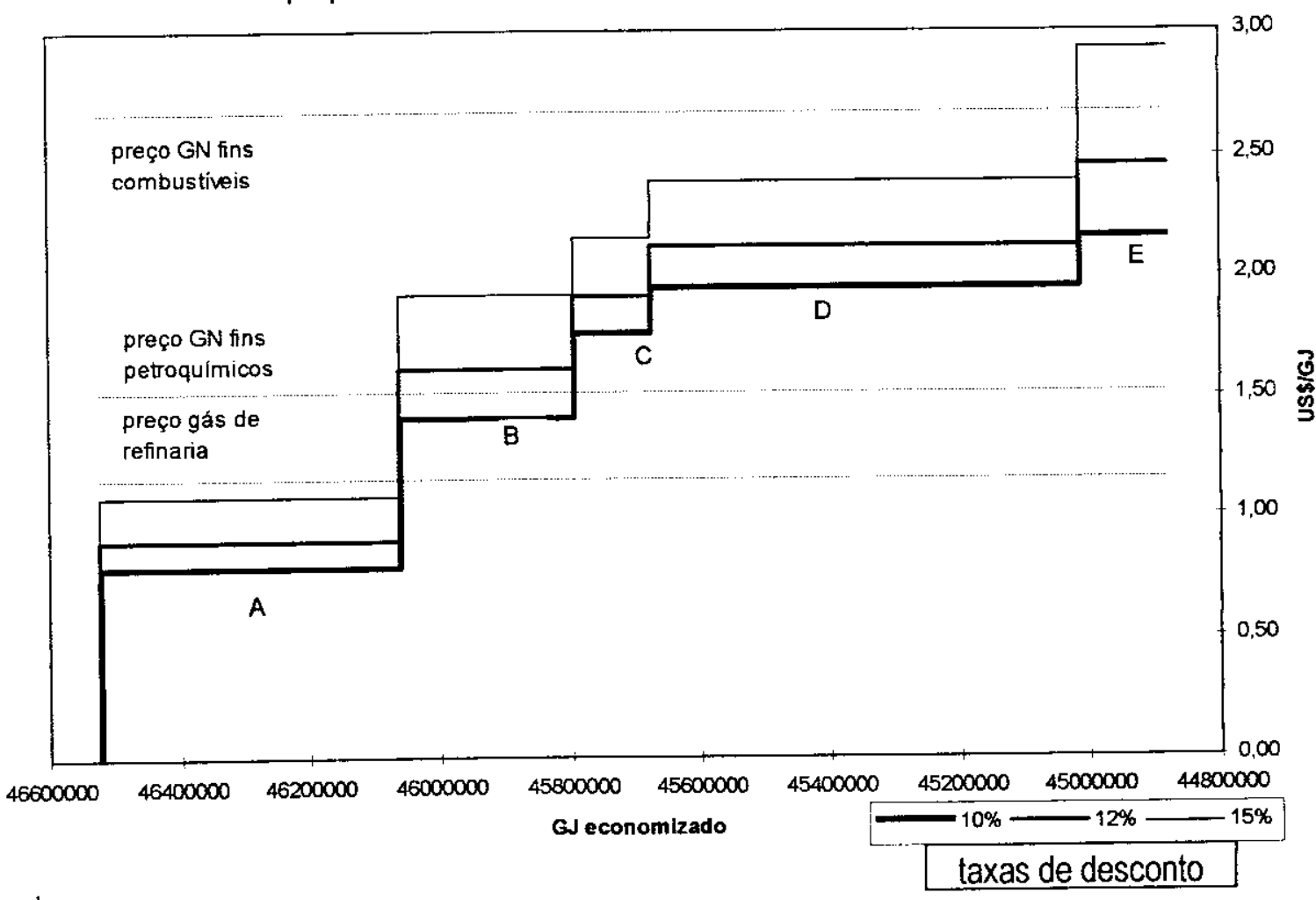

onde:

A - modificação nos reatores de sintese, unidades Camaçari,BA e Laranjeiras,SE.

$B$ - instalação de pré-aquecimento de gás de combustão, unidade Camaçari,BA.

C - instalação de sistema de recuperação de gás de purga por membranas, Piaçaguera,SP.

$D$ - instalação de sistema de recuperação criogênica de gás de purga, Camaçari,BA e Laranjeiras,SE.

E - instalação de pré-aquecimento de ar de combustão, Piaçaguera,SP.

As análises efetuadas permitem concluir que 0 custo da instalação da tecnologia de recuperação criogênica de gás de purga (unidades Camaçari,BA e Laranjeiras,SE), a taxas de desconto de $10 \%, 12 \%$ e $15 \%$ a.a., apresenta-se abaixo do custo do gás natural para fins combustiveis.

Quando comparado ao custo do hidrocarboneto para fins petroquimicos, a opção torna-se mais cara do que investir na compra da matéria-prima. 
Já para a unidade de Piaçaguera,SP, devido ao baixo custo do gás de refinaria, a instalação de recuperação do gás de purga por membranas é inviável, considerando-se as três taxas de desconto.

A economia principal com a implementação destes equipamentos aparece na redução do uso de combustivel, na fornalha do reformador primário, para a obtenção do hidrogênio.

0 pré-aquecimento de ar de combustão na unidade de Piaçaguera,SP não se mostrou uma medida de conservação de energia viável, a taxas de desconto de 10, 12 e 15\%a.a., quando comparada ao preço do gás de refinaria.

Contradizendo as informações encontradas na bibliografia, para a unidade de Camaçari, BA, o custo da energia conservada através de pré-aquecimento apresenta-se inferior ao custo do combustivel para as três taxas de desconto. Apresenta-se, também, inferior ao custo de outras medidas de conservação de energia propostas no trabalho. $O$ preço do gás natural para fins petroquímicos não entra nesta comparação porque a economia de energia proveniente desta medida é na redução da queima de hidrocarboneto combustivel na fornalha do reformador primário.

Conservar energia com a modificação no reator de sintese (unidades de Camaçari,BA e Laranjeiras,SE) é viável para as três taxas de desconto e com relação tanto ao preço do gás natural para fins combustiveis como para fins petroquímicos. A comparação é feita para as duas finalidades porque a energia de compressão economizada é gerada por compressores movidos a turbinas a vapor, gerado por trocas de calor (produzido tanto na combustão quanto nas reações químicas do processo). Portanto, economiza de uma maneira geral, matéria-prima e combustivel.

É importante salientar que esta análise reflete apenas a situação momentânea, porque a viabilidade das medidas de conservação de energia pode sofrer mudanças mediante a variação nos preços do gás natural e das outras matérias-primas. A reestruturação em curso no setor energético deverá aproximar os preços dos custos marginais como consequência da aproximação deste setor ao realismo de mercado competitivo, tornando os investimentos em conservação de energia mais atraentes para o setor de fertilizantes nitrogenados.

A redução possivel no consumo de energia para a fabricação de amônia, baseada na análise econômica, é inferior aos valores indicados anteriormente na tabela 3.13 , onde somente a viabilidade tecnológica havia sido apontada. A tabela 3.20 demonstra, então, o resultado reformulado do efeito das medidas de conservação de energia. 
Tabela 3.20. Medidas de conservação de energia para unidades de amônia viáveis economicamente e o efeito no consumo de energia.

\begin{tabular}{|c|c|c|c|c|c|c|c|c|}
\hline \multirow[b]{2}{*}{ unidades } & consumd & \multicolumn{5}{|c|}{ potencial de conservação GJ/t amónia } & \multirow{2}{*}{$\begin{array}{r}\text { consumg } \\
\text { com } \\
\text { medidas } \\
\text { GJ/tamônia }\end{array}$} & \multirow{2}{*}{$\begin{array}{r}\% \\
\text { economizada } \\
\text { de energia }\end{array}$} \\
\hline & $\begin{array}{r}\text { atuat } \\
\text { GJ } / \\
\text { amônia }\end{array}$ & $\begin{array}{r}\text { gás de } \\
\text { purga } \\
\text { criogênica }\end{array}$ & $\begin{array}{r}\text { gás de } \\
\text { purga } \\
\text { membranas }\end{array}$ & $\begin{array}{r}\text { reator } \\
d e \\
\text { sintese }\end{array}$ & $\begin{array}{r}\text { pre } \\
\text { aquecimento }\end{array}$ & $\begin{array}{r}\text { pre } \\
\text { aquecimento }\end{array}$ & & \\
\hline Camaçari & 34,66 & 1,0 & 0 & 0,7 & 0,8 & 0 & 32,16 & 7,2 \\
\hline Laranjeiras & 34,27 & 1,0 & 0 & 0,7 & 0 & 0 & 32,57 & 4,9 \\
\hline Piaçaguera & 37,49 & 0 & 0 & 0 & 0 & 0 & 37,49 & 0,0 \\
\hline Araucária & 41,17 & 0 & 0 & 0 & 0 & 0 & 41,17 & 0,0 \\
\hline
\end{tabular}

\begin{tabular}{|l|c|c|c|c|c|c|c|c|}
\hline anualmente & consumido & \multicolumn{9}{|c|}{ economizado } \\
\cline { 2 - 9 } & GJ & GJ & GJ & GJ & GJ & GJ & total GJ & \% econ. \\
\hline Camaçari & 12.477 .600 & 360.000 & 0 & 252.000 & 288.000 & 0 & 11.577 .600 & 7,2 \\
\hline Laranjeiras & 11.309 .100 & 330.000 & 0 & 231.000 & 0 & 0 & 10.748 .100 & 4,9 \\
\hline Piaçaguera & 6.433 .284 & 0 & 0 & 0 & 0 & 0 & 6.433 .284 & 0,0 \\
\hline Araucária & 16.303 .320 & 0 & 0 & 0 & 0 & 0 & 16.303 .320 & 0,0 \\
\hline
\end{tabular}

total

As propostas de revamp para a unidade de Piaçaguera,SP foram as responsáveis pela diminuição do potencial de conservação total de energia. Ao invés de atingir uma média de 35,47 GJ/t amônia chegou-se a um valor de 35,84 GJ/t amônia. Este valor significa uma redução de 2,84\% na média brasileira de consumo de energia para a produção de amônia.

Examinando o efeito das medidas de conservação de energia somente nas unidades que empregam o processo de reforma com vapor d'água (excluindo a unidade de Araucária,PA), a média é capaz de refletir melhor os resultados. 0 consumo médio de energia passaria dos $35,47 \mathrm{GJ} / \mathrm{t}$ amônia atuais para 33,57 GJ/t amônia, o que equivale a uma diminuição de $5,35 \%$ no consumo de energia na produção de amônia pelo processo de reforma com vapor d'água.

Anualmente, esta economia seria de $1.461 .000 \mathrm{GJ}$, o que é equivalente a $36.805 .512 \mathrm{~m}^{3}$ de gás natural (tabela 3.16) - uma vez e meia a produção diária total do hidrocarboneto em 1996.

Tabela 3.21. Economia de matéria-prima atingida com as medidas de conservação de energia.

\begin{tabular}{|c|c|c|c|c|c|c|c|}
\hline unidade & $\begin{array}{l}\mathrm{PCl} \\
\mathrm{GJHA} \\
\end{array}$ & $\begin{array}{c}\text { t matéria-prima } \\
\text { economizada / ano }\end{array}$ & $\begin{array}{c}\text { MMBtu } \\
\text { lano }\end{array}$ & $\mathrm{m}^{3}$ /ano & $\mathrm{m}^{3} / \mathrm{dia}$ & $\begin{array}{l}\mathrm{CCO}_{2} \text { não emitidas } \\
\left(1,5+\mathrm{CO}_{2} / \text { gás natural }\right)\end{array}$ & $\begin{array}{l}\mathrm{tNO} \mathrm{N}_{x} \text { não emitidas } \\
\left(0,002 \mathrm{t} \mathrm{NO}_{x} \text { tgás natural) }\right.\end{array}$ \\
\hline $\begin{array}{l}\text { Camaçari - } \\
\text { gás natural }\end{array}$ & 51,50 & 17.476 & 846.000 & 22.672 .800 & 62.980 & 26.214 & 35,83 \\
\hline $\begin{array}{l}\text { Laranjeiras - } \\
\text { gás natural }\end{array}$ & 46,68 & 12.018 & 527.340 & 14.132 .712 & 39.257 & 18.027 & 24,64 \\
\hline $\begin{array}{l}\text { Piaçaguera- } \\
\text { gás de refinaria }\end{array}$ & 45,22 & 0 & 0 & 0 & 0 & & \\
\hline $\begin{array}{c}\text { Araucária - } \\
\text { RASF } \\
\end{array}$ & 39,52 & 0 & 0 & 0 & 0 & & \\
\hline & & 29.494 & 1.373 .340 & 36.805 .512 & 102.237 & 44.214 & 60,46 \\
\hline
\end{tabular}

total 
As emissões de $\mathrm{CO}_{2}$ e NO evitadas com a economia de gás natural atingiriam 44.241 tano e 60,46 tano, respectivamente.

Em termos financeiros, esta redução no consumo de energia significa investir ao redor de US\$2.200.000,00 por ano, a uma taxa de $12 \%$ a.a.. Como figuras gerais, obtem-se US\$ $1,54 / G J$ economizado ou US $\$ 0,06 / \mathrm{m}^{3}$ gás natural economizado.

Empregando, por exemplo, os preços do gás natural fornecidos pela Agência para Aplicação de Energia (tabela 3.14), chega-se a um valor aproximado de US $\$ 3.200 .000,00$ relativos ao hidrocarboneto que deixaria de ser comprado. Isto resulta, finaimente, em uma economia real de US\$ $1.000 .000,00$ por ano para o setor produtor de amônia.

Finalmente, a tabela abaixo e 0 gráfico identificam 0 efeito do aumento da eficiência energética na indústria de amônia sobre o consumo de energia para produção de fertilizantes. Para isso, novos cálculos de consumo de energia foram efetuados utilizando o novo valor médio de consumo de energia para produção de amônia. Uma redução de apenas $2,84 \%$ no consumo médio de energia para a produção de amônia resultaria em diminuição de 7 a 18\% no consumo de energia para a produção de fertilizantes.

Tabela 3.22. Efeito da redução do consumo energético na industria de amônia sobre o consumo de energia para produção de fertilizantes.

\begin{tabular}{|c|c|c|c|c|c|c|c|}
\hline & \multicolumn{3}{|c|}{ GJ/t produto } & \multirow{4}{*}{\begin{tabular}{|r|}
$\begin{array}{c}\text { para produçäo do } \\
\text { amônia }\end{array}$ \\
novo \\
CEEg \\
\end{tabular}} & \multicolumn{3}{|c|}{ para fertifizantes } \\
\hline & \multicolumn{2}{|c|}{ atual } & \multirow[b]{2}{*}{$\mathrm{tNH} 3 /$ t ferte } & & novo & novole & \\
\hline & CFFea & $\mathrm{CEEg}^{\mathrm{a}}$ & & & & CEEg & redução \\
\hline fertilizante & $\frac{21,5}{21}$ & 25,9 & 0,555 & & 19,32 & 23,72 & \\
\hline uréia & 21,5 & 20,7 & & & 17,42 & $\frac{20,12}{18.27}$ & $\begin{array}{r}8,42 \\
11,74\end{array}$ \\
\hline nitrato de amônio & $\frac{19,8}{178}$ & 19,2 & $\frac{0,500}{0,470}$ & 35,84 & $\frac{11,42}{16,37}$ & $\frac{18,21}{1777}$ & $\frac{11,74}{740}$ \\
\hline nitrocálcio & 17,8 & 12,6 & $\frac{0,470}{0,320}$ & 35,84 & $\frac{16,31}{11,15}$ & $\frac{17,77}{1174}$ & 7,42 \\
\hline sulfato de amônio & 12,01 & 10,8 & $\frac{0,320}{0,136}$ & 35,84 & & 11,74 & 6,83 \\
\hline map & 6,36 & $\frac{10,0}{14,3}$ & $\begin{array}{l}0,136 \\
0,222\end{array}$ & 35,84 & 4,74 & 9,18 & 15,02 \\
\hline & & & 0,222 & 35,84 & 7,73 & 11,63 & 18,64 \\
\hline
\end{tabular}

a: BRUNO et al.(1985). 
Gráfico 3.15. Redução no consumo de energia para produção de fertilizantes devido ao aumento da eficiência energética na indústria de amônia.

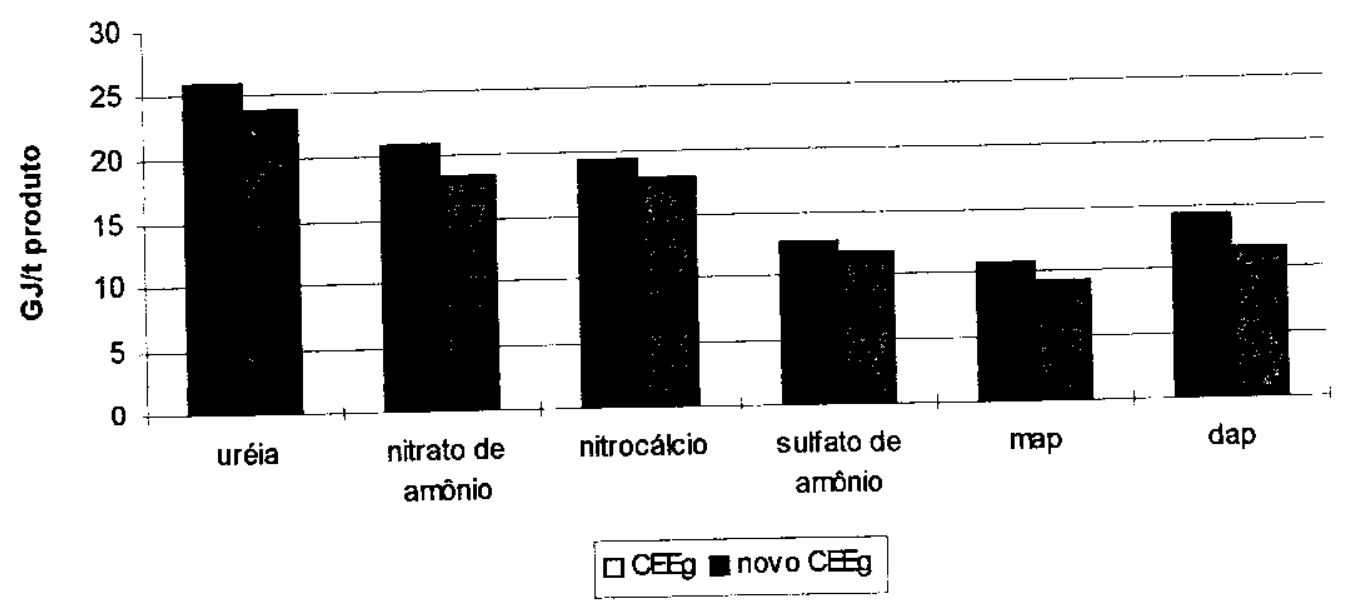




\section{CONSTRUCÃO DE CENÁRIOS DE DEMANDA DE NITROGÊNIO: UM ESTUDO DE CASO DA CULTURA DO MILHO NO BRASIL}

\subsection{Introdução}

A América Tropical, área entre os trópicos de Câncer e Capricómio, apesar de apresentar grande potencial para a produção agricola, possui limitações no sentido do fornecimento de nutrientes pelos solos. Dos 1.493 .000 .000 ha, $89 \%$ apresentam como fator limitante no solo, deficiência de nitrogênio, $82 \%$ apresentam deficiência de fósforo e $54 \%$, deficiência de potássio (CASTRO et al., 1987).

O emprego de fertilizantes minerais foi apontado como solução para o melhoramento da fertilidade dos solos tropicais $e$, junto com os demais insumos agrícolas, permitiram 0 desenvolvimento de sistemas agrícolas de alta produtividade. $O$ uso adequado de fertilizantes minerais e corretivos é citado como responsável por até $50 \%$ dos ganhos em produtividade (RAIJ, 1991).

A fonte de nitrogênio preferida pelos agricultores são os fertilizantes minerais nitrogenados devido ao seu efeito rápido e da relativa facilidade de seu manuseio. Entretanto, sua eficiência de utilização por cereais é baixa em regiões tropicais e sub-tropicais. Em termos de grandeza, BRAUN (1993) indica uma eficiência em torno de $50 \%$ do nutriente quando aplicado ao solo e, em casos extremos, em uma faixa de 30 a $70 \%$.

As perdas elevadas tornam-se uma barreira na aplicação das doses de nitrogênio recomendadas para culturas como arroz, milho, trigo e sorgo com a finalidade de responder ao potencial de produtividade quando são utilizadas as variedades de alto potencial produtivo (PRASAD, 1986).

A baixa eficiência do fertilizante mineral nitrogenado nestas culturas e regiões é consequência das severas perdas de nitrogênio provocadas por chuvas pesadas em curtos espaços de tempo e pela precariedade das práticas de manejo agricola (PRASAD, 1986).

Embora o desenvolvimento tecnológico na indústria e na agricultura tenha melhorado a eficiência dos fertilizantes, as perdas são ainda excessivas em muitos casos, principaimente em 
agriculturas menos tecnificadas, situação que ocorre em paises em desenvolvimento (BRAUN; 1993).

$O$ conceito de eficiência de um fertilizante pode ser definido como o aumento de produção por unidade de nutriente aplicado. Baixa eficiência de fertilizantes significa baixa produtividade e baixos lucros (LOPES \& GUILERME, 1992; PRASAD, 1986).

De acordo com PRIMAVESI (1987), aproximadamente $50 \%$ do nitrogênio adubado não é aproveitado, porque:

- escapa para o ar (volatilização) ou é lixiviado.

- a raiz não o alcança devido ao adensamento do solo.

- a seca, com sua falta de água, impede a absorção.

- falta o fósforo e, em menor escala, outros nutrientes para sua metabolização (Lei do Minimo).

- elevada concentração de aluminio no subsolo, constituindo uma barreira química ao crescimento radicular.

Sob circunstâncias desfavoráveis, como alta precipitação, extensos períodos de seca, solos erodidos e com baixo conteúdo de matéria orgânica, a eficiência do fertilizante mineral nitrogenado nas lavouras tropicais pode ser menor do que 50\% (REIJNTES et al., 1994).

Além disso, a utilização incorreta deste insumo pode perturbar a vida do solo e seu equilibrio: aumenta a taxa de decomposição de matéria orgânica, levando à degradação da estrutura do solo com consequente aumento da vulnerabilidade à seca e uma menor eficácia produtiva.

Para PRIMAVESI (1987), existem duas maneiras de adubar. Uma para aumentar a colheita, por necessitar de alimentos a qualquer custo, e a outra para se obter um lucro maior pela atividade agrícola. Verifica-se no gráfico 4.1 que o aumento da adubação pode aumentar a colheita ainda acima do ponto $A_{1} / R_{2}$. Entretanto, deste ponto em diante, com o aumento progressivo de adubo, a colheita não aumenta mais, começando a diminuir, até que a elevação da dose de fertilizante provoca queda na produção. 
Gráfico 4.1. Doses de adubo e seu efeito da produtividade.

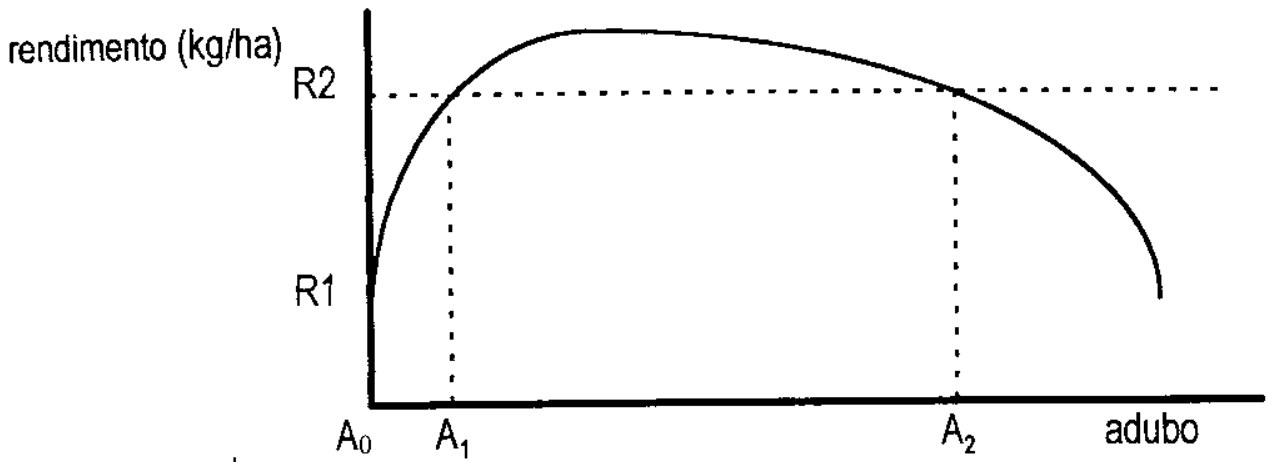

onde:

$\mathrm{R}_{2}$ - rendimento com adubo

$A_{0}$ - quantidade de adubo nula

$R_{1}$ - rendimento sem adubo

$A_{1}$ - quantidade de adubo para aumentrar a colheita ao máximo

$A_{2}$ - quantidade de adubo $\%$ vezes de $A_{1}$, porém produzindo colheita idêntica

fonte: PRIMAVESI (1987).

Quando se admite a dinâmica e a interdependência de vários fatores influenciando 0 sistema agrícola, conclui-se que alcançar bons resultados com a adubação depende de outras práticas agrícolas. Estas práticas estão associadas a: propriedades do solo, tipo de cultura, cultivares, fatores ambientais e manejo agronômico. Em cada um destes itens, algumas caracteristicas são consideradas importantes, se consideradas apropriadamente, como uma forma de elevar a eficiência da utilização de fertilizantes minerais nitrogenados (quadro 4.1).

Quadro 4.1. Fatores que afetam a eficiência da adubação.

\begin{tabular}{|c|c|}
\hline - características do solo & - caracteristicas da cultura \\
\hline $\begin{array}{l}\text { - fertilidade inicial } \\
\text { - textura e estrutura } \\
\text { - } \text { pH } \\
\text { - } \text { topografia } \\
\text { - drenagem } \\
\text { - } \text { salinidade / alcalinidade } \\
\end{array}$ & $\begin{array}{l}\text { - escolha da cultura } \\
\text { - escolha da variedade, e seu potencial produtivo } \\
\text { - resistência da variedade a doenças e pragas } \\
\text { do solê, como salinidade, acidez, etc }\end{array}$ \\
\hline - fatores ambientais & - práticas de manejo agronômico \\
\hline $\begin{array}{l}\text { - pluviosidade e sua distribuição sazonal } \\
\text { - dias de sol e horas de insolação } \\
\text { - ocorrência de geada } \\
\text { - incidência de doenças e pragas }\end{array}$ & $\begin{array}{l}\text { - época de plantio } \\
\text { - } \text { população de plantas adequada } \\
\text { - } \text { manejo da água } \\
\text { - controle de invasoras } \\
\text { - } \text { adubação balanceada } \\
\text { - } \text { métodos de aplicação de fertilizantes }\end{array}$ \\
\hline
\end{tabular}

fonte: PRASAD (1986). 
Pode-se afirmar que o manejo correto dos FMN resulta em beneficios muito mais amplos do que a melhora do aproveitamento do nutriente pelas culturas.

$O$ aumento da eficiência dos FMN traz, em primeira instância, melhores resultados financeiros ao agricultor. Afinal, ele estará investindo em uma mesma quantidade de insumo, porém alcançando uma produção maior (resultante da maior disponibilidade do nutriente).

A contaminação da água e do solo por compostos nitrogenados pode também ser reduzida quando o fertilizante mineral nitrogenado é manejado corretamente porque resulta em menores perdas.

Por último, chega-se na dimensão da conservação de energia. Sabendo que os fertilizantes minerais nitrogenados têm um alto conteúdo energético devido aos processos produtivos e da matéria-prima que utilizam, evitar perdas deste insumo reflete diretamente em uma economia de combustiveis fósseis.

Salientando-se que esta energia, quando desperdiçada, é dissipada no meio ambiente sob a forma dos gases provenientes da combustão no processo industrial e sob a forma do próprio nutriente, o qual pode ir tanto para a atmosfera quanto para o lençol freático.

Os fertilizantes minerais nitrogenados, sob 0 aspecto produtivo atual, podem ser classificados como produtos não renováveis e, diferentemente de outros produtos, não podem ser reaproveitados por causa da forma como são dissipados na natureza.

Sob a esfera da conservação de energia e da não renovabilidade dos FMN, deve-se argumentar que existem disponiveis para a agricultura outras fontes de nitrogênio com diferentes caracteristicas relacionadas a estes fatores.

A adubação verde, por exemplo, é uma fonte de nitrogênio que pode ser considerada renovável. E, com relação ao consumo de hidrocarbonetos, para disponibilizar o nitrogênio para culturas comerciais, esta fonte apresenta requerimento zero de energia fóssil.

A pesquisa e a prática agronômica já comprovaram a eficácia tanto do manejo correto dos FMN quanto da prática de adubação verde. Portanto, estas práticas podem ser adotadas pelos agricultores como medidas de economia de insumo/energia. 
Através da construção de cenários ${ }^{1}$ de demanda de nitrogênio para a cultura do milho, em uma perspectiva de planejamento, será possivel verificar o efeito da adoção dessas medidas de economia na demanda do nutriente.

\subsubsection{Importância da Cultura do Milho}

É necessário justificar a escolha da cultura do milho para a execução da análise. Para a presente dissertação, em virtude da amplitude da pesquisa e dificuldade de obtenção de dados, não foi possivel construir cenários para a agricultura como um todo, isto é, englobar as principais culturas produzidas no Brasil (dezesseis, de acordo com a ANDA). Por isto, optou-se por escolher uma cultura representativa em termos de área ocupada, consumo de fertilizantes, quantidade produzida, número de produtores, além de outras características.

O Brasil é o terceiro maior produtor de milho do mundo, após os Estados Unidos e China (OLIVEIRA, 1992). No Mercosul, o Brasil produz três vezes mais do que a Argentina.

No pais, o milho é o grão mais produzido, ocupando $36,6 \%$ da área cultivada e representando $44 \%$ da produção brasileira de grãos. Apesar de apresentar índices médios de produtividade extremamente baixos, a cultura do milho representa $16 \%$ do consumo de fertilizantes.

Além disso, o milho é uma importante fonte de energia, tanto para o ser humano quanto para os rebanhos. Seus maiores consumidores no Brasil são o setor avicola e suinicola, com consumos de 33,6 e 17,1\% da oferta, respectivamente. Indiretamente, portanto, o consumo de milho está ligado à evolução dos niveis de renda da população, pois carnes são produtos com elasticidade-renda positiva (AGRIANUAL 1997).

Outra característica desta cultura é sua forte dispersão geográfica em todo o território nacional. De acordo com MONTEIRO (1997), "cerca de quatro milhóes de produtores cultivam aproximadamente 13 milhões de hectares com milho no Brasil, praticamente em todos os locais onde seja possivel utilizar um pedaço de terra."

Os diferentes sistemas tecnológicos, postos a seviço da produção do grão, determinam, por sua vez, a segmentação dos produtores, classificando-os com base no seu nivel técnico. Assim, os

\footnotetext{
1 Um cenário é uma sequência imaginada de eventos.

Cenário é uma projeção condicional da evolução de um sistema. Seu pressuposto de base é que existem vários futuros viáveis e qualitativamente distintos, segundo opç̃es politicas do decisor e segundo fatores que escapam a seu controle (ARAUJO, 1988).
} 
que se acham na tiderança já obtêm produtividades superiores a 6 mil $\mathrm{kg} /$ ha de milho, constituindose em agricultores de alta tecnologia. Os da faixa intermediária (de boa a alta) produzem de 4500 a $6000 \mathrm{~kg} / \mathrm{ha}$. A terceira classe, a grande maioria, é constituida pelos que colhem menos do que isso e, aqueles que se acham nos patamares inferiores, por certo, têm ameaçada sua sobrevivência como produtores de mitho (AGRIANUAL 1996).

Por ser um vegetal da familia das gramineas, o milho apresenta reduzida capacidade de estabelecer uma relação sombiótica com as bactérias fixadoras de nitrogênio para suprir sua necessidade, o que o torna dependente de um fornecimento de outras fontes do nutriente.

\subsection{Consumo de Nitrogênio no Brasil}

\subsubsection{Consumo de Fertilizante Mineral Nitrogenado}

Os fertilizantes apresentam uma demanda derivada, fazendo com que o desempenho da agricultura seja de fundamental importância neste mercado (PUGGINA, 1993).

O último CENSO AGROPECUÁRIO (IBGE, 1980) consolidado indica que existe uma variação da porcentagem de agricultores que empregam fertilizantes minerais de acordo com a cultura. Somente a cultura da mandioca apresenta menos da metade de seu agricultores empregando adubação mineral. Todas as outras culturas representadas apresentam mais de $50 \%$ dos agricultores se beneficiando por tal técnica. A situação atual (1997-98) deve refletir maiores proporções se observarmos a elevação da demanda de tais insumos.

Outra característica do consumo de fertilizantes é o fato de a maioria do insumo ser consumida sob a forma de fórmulas onde os três principais macronutrientes - NPK - são vendidos conjuntamente.

Para o Estado de São Paulo, o novo CENSO AGROPECUÁRIO (IBGE, 1997) indicou que $95 \%$ da área plantada com milho utilizou fertilizante mineral na safra 95-96, o que é equivalente a $96,7 \%$ da produção.

Entretanto, apesar do uso de fertilizantes minerais ser uma técnica amplamente difundida, existe uma diferença entre culturas quanto ao montante de fertilizantes aplicado (gráfico 4.2). As culturas consideradas de exportação são as predominantes no emprego de fertilizantes. Os dados mostram que cerca de $80 \%$ do consumo do insumo está concentrado em apenas 10 culturas, com destaques para cana-de-açucar, soja e milho. 
Gráfico 4.2. Consumo de fertilizantes por cultura, 1992.

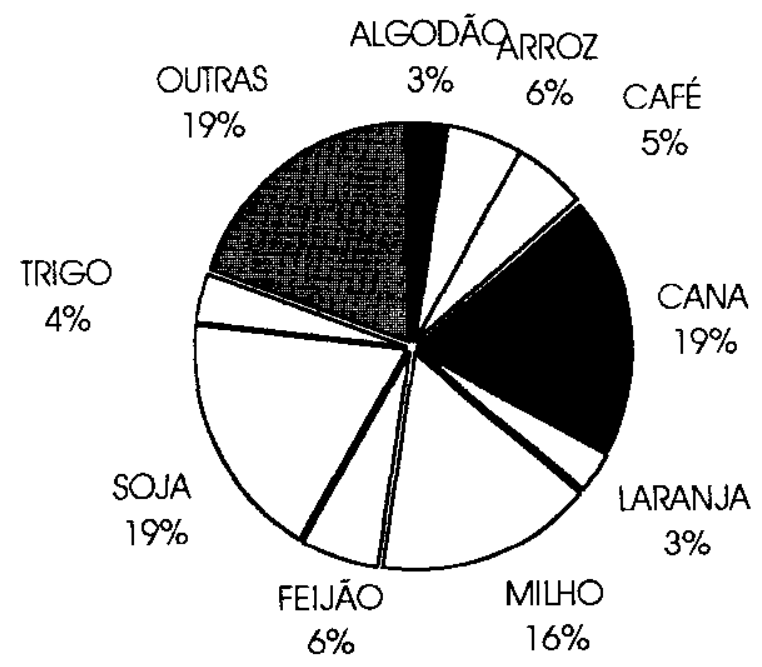

fonte: ANDA, 1992.

De acordo com HOMEM DE MELO (1996), a agricultura tem melhorado sua eficiência, na medida em que se eleva a produtividade da terra em $22,3 \%$ entre 88 e 94 devido ao maior uso de fertilizantes por hectare cultivado (gráfico 4.2), ao mesmo tempo que os custos se reduzem, pois o preço médio real do fertilizante teve um declínio de 34\% entre 1988 e 1994.

Gráfico 4.3. Evolução dos indices de produtividade da terra, preços reais de fertilizantes e uso de fertilizantes/ ha cultivado $(1988=100)$.

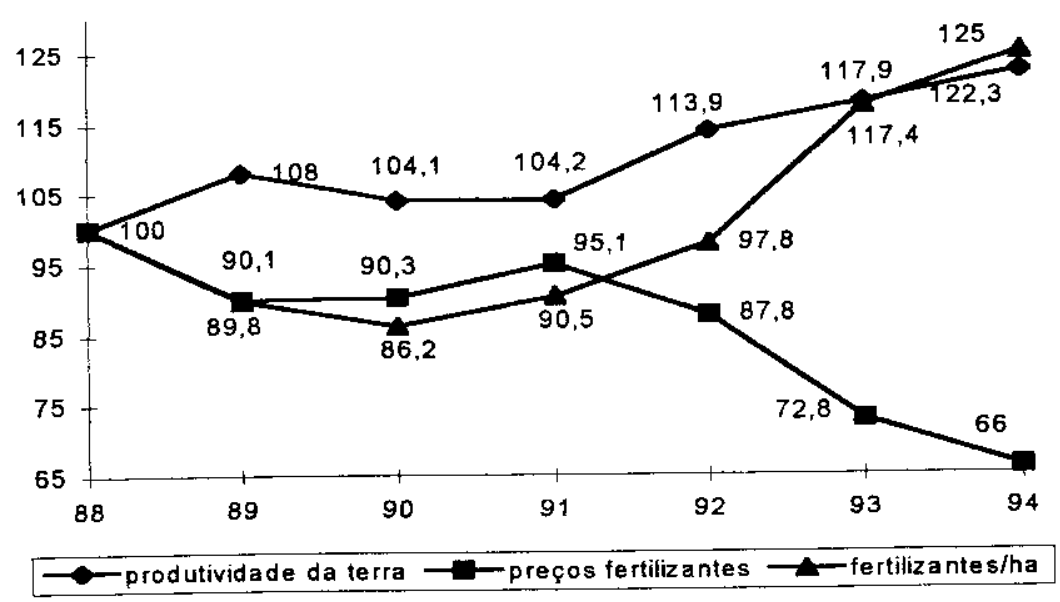

fonte: ANDA, FGV, IBGE apud HOMEM DE MELO, 1996.

A análise da evolução da utilização de fertilizantes minerais por algumas culturas individualmente mostra que existem diferenças no ritmo de crescimento da quantidade consumida (gráfico 4.4). 
Observa-se, também, que a taxa de crescimento da quantidade de nitrogênio consumida por cultura apresenta sempre maiores índices quando comparada às taxas de crescimento do consumo de fertilizantes minerais (gráfico 4.4).

Para a agricultura como um todo, os indices também são mais elevados para a evolução da quantidade de nitrogênio do que para o montante de fertilizantes. $E$, apesar de existir em algumas culturas onde houve uma redução no consumo de nitrogênio e fertilizantes, a taxa geral foi positiva (gráfico 4.4).

Gráfico 4.4. Taxas de crescimento (\%a.a.) da quantidade de fertilizantes minerais e nitrogênio consumidos por diferentes culturas (periodo: 1987-95).

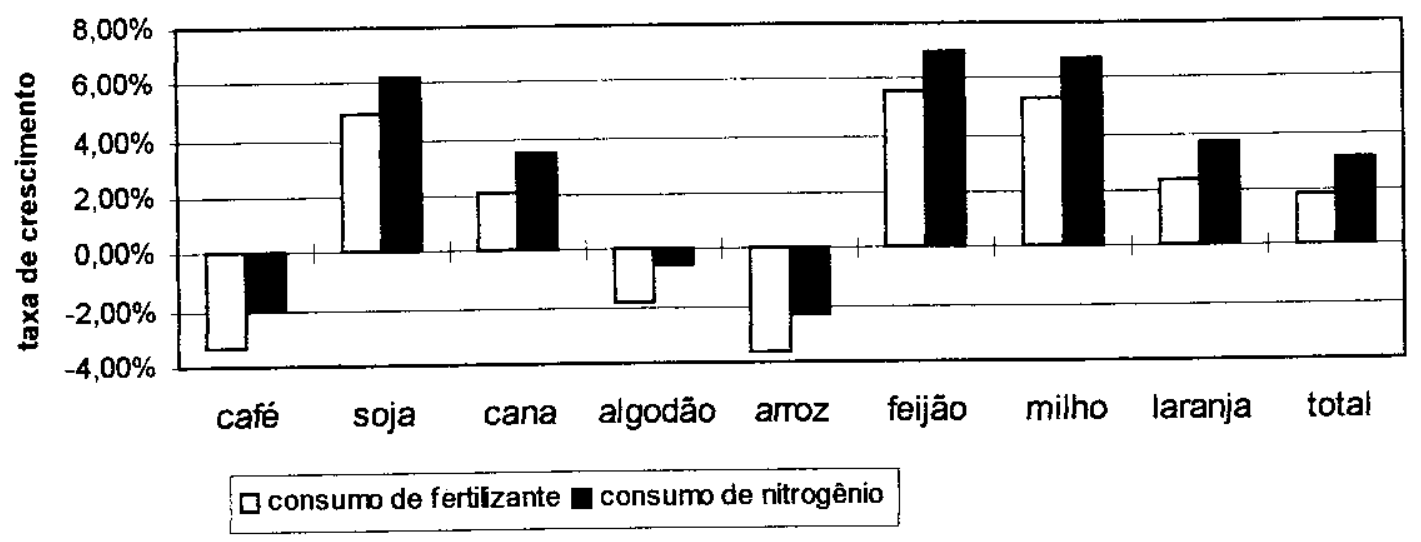

fonte: elaborado a partir de FERREIRA (1996).

A evolução das taxas de crescimento de consumo de nitrogênio mostra que houve uma recuperação no consumo entre 90 e 93, e depois um crescimento negativo de $-3,17 \%$ em 95 . HOMEM DE MELO (1996) explica que a agricultura enfrentou, no primeiro semestre de 95, principal período de comercialização, um sério problema de queda de receita, provocado pela acentuada redução de preços reais recebidos pelos produtores. Com isso, o agricultor se descapitaliza e deixa de comprar insumos. Examinando-se o desenvolvimento dos índices de consumo de nitrogênio desde 1975, pode-se dividir o periodo em quatro fases: 75 a 80 grande crescimento do consumo; 80 a 84 redução brusca; 85 a 92 apresentando-se praticamente estável, mudando de patamar somente a partir de 93 (gráfico 4.5). 
Gráfico 4.5. Evolução de indices de consumo de nitrogênio (1975=100).

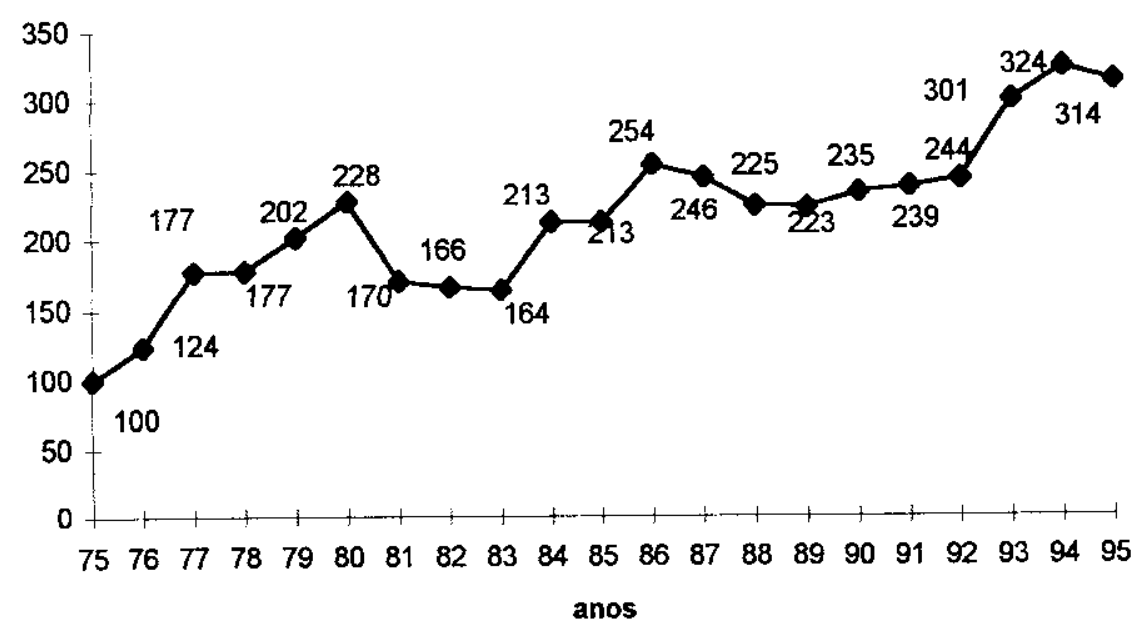

fonte: elaborado a partir de NEPTUNE (1986) e SOLORRICO (1996).

Para o milho, a taxa de crescimento do consumo de fertilizantes N-P-K por unidade de área no periodo $1989-95$ foi de $7,95 \%$ a.a., contribuindo com $80 \%$ do aumento do consumo total. Portanto, o aumento da área de milho contribuiu com apenas $20 \%$ da elevação do consumo no período. Com relação à quantidade média consumida por hectare, houve um acréscimo, passando de 110,8 kg/ha em 1989 para 163,5 kg/ha em 1994 e, posteriormente um declínio para 147,7 kg/ha em 1995. Como esta quantidade corresponde a $59 \mathrm{~kg} / \mathrm{ha}$ de nutrientes (TSUNECHIRO \& FERREIRA, 1996) e sabendo-se que a concentração média de nitrogênio nos dados estatisticos é ao redor de 10\%, tem-se $6 \mathrm{~kg} \mathrm{~N}$ sendo aplicados por hectare na cultura do milho.

Diante desta reduzida quantidade de nutrientes sendo fornecida para a cultura do milho por unidade de área, os dados de consumo de fertilizantes minerais que indicam um consumo de $16 \%$ do total por esta cultura, se justificam pela sua extensa área cultivada. Existe, portanto, potencial de crescimento do consumo de fertilizantes nitrogenados via aumento do consumo por unidade de área. 


\subsubsection{Fatores Econômicos que Afetam a Demanda}

A decisão dos agricultores sobre a quantidade de fertilizante a ser usado por área cultivada é um determinante importante do nivel de produção agrícola. Se essa decisão depender da razão de preços $^{2}$, dada a produtividade do insumo (supondo que os agricultores procurem maximizar lucros), então, o processo de formação dos preços na indústria de fertilizantes deve influenciar de forma apreciável na oferta agregada de produtos agricolas (DIESEL, 1996). A autora conclui que, sob o enfoque do bem-estar da sociedade, o desempenho econômico da indústria de fertilizantes influencia a renda agricola e o nivel geral de preços, pois os produtos agricolas têm grande peso no indice de preços por atacado e no indice de custo de vida.

Os preços industriais são considerados "fixed prices" e os preços agricolas tipicamente "flex prices" (HICKS, 1974 apud DIESEL, 1996). A flutuação dos primeiros, em função da instabilidade dos custos de produção, sujeitam os agricultores a uma elevada dose de incerteza, que se eleva quanto maior o poder de monopólio da indústria a montante e a jusante da agricultura (DIESEL, 1996).

A participação do custo de adubação N-P-K na receita da produção agricola varia de cultura para cultura (tabela 4.1). O milho é a cultura que sofre maior influência dos custos com adubação $(21,5 \%)$, seguido pelo trigo $(13,1 \%)$, soja e arroz (ambos com $11 \%$ ). A participação elevada do custo da adubação nas culturas deve ser vista com cuidado quando efetuarem-se comparações. Isto porque a disparidade entre as rendas agricolas obtidas em cada produto é grande (tabela 4.1). 0 fato de existirem culturas com maior incidência de emprego de ferilizantes minerais também pode influenciar na participação da adubação no custo de produção.

${ }^{2} \mathrm{RT}=\left(\mathrm{P}_{1}, Q_{1}\right) /\left(\mathrm{P}_{\mathrm{a}}, \mathrm{Q}_{\mathrm{a}}\right)$, onde

$R T=$ relação de troca

$P_{1}=$ preço médio do fertilizante

$Q_{1}=$ quantidade média do fertilizante

$P_{a}=$ preço médio do produto agricola

$Q_{a}=$ produtividade agricola média 
Tabela 4.1. Participação do custo da adubação na receita de produção (US\$/ha).

\begin{tabular}{|ll|r|r|r|}
\hline & & & \\
ano & 90 & 93 & 95 \\
\hline algodão receita & 1395,00 & 1290,00 & 1727,50 \\
& adubação & 152,74 & 108,14 & 126,00 \\
& part. \% & 10,9 & 8,4 & 7,3 \\
\hline arroz & receita & 741,00 & 631,80 & 754,00 \\
& adubação & 101,6 & 72,42 & 83,00 \\
& part. \% & 13,7 & 11,5 & 11,0 \\
\hline cana & receita & 843,20 & 779,20 & 1089,00 \\
& adubação & 122,97 & 83,85 & 105,00 \\
& part. \% & 14,6 & 10,8 & 9,6 \\
\hline feijão & receita & 1219,40 & 1061,55 & 1146,95 \\
& adubação & 120,72 & 82,25 & 94,00 \\
& part.\% & 9,9 & 7,7 & 8,2 \\
\hline citrus & receita & 2016,00 & 2072,00 & 4048,00 \\
& adubação & 151,14 & 98,48 & 123,00 \\
& part. \% & 7,5 & 7,8 & 3,0 \\
\hline milho & receita & 539,00 & 483,00 & 515,20 \\
& adubação & 138,47 & 100,05 & 111,00 \\
& part. \% & 25,7 & 20,7 & 21,5 \\
\hline soja & receita & 375,48 & 447,30 & 443,94 \\
& adubação & 73,13 & 44,32 & 49,00 \\
& part. \% & 19,5 & 9,9 & 11,0 \\
\hline trigo & receita & 311,64 & 310,80 & 389,34 \\
& adubação & 76,23 & 41,10 & 51,00 \\
& part. \% & 24,5 & 13,2 & 13,1 \\
\hline café & receita & 1533,60 & 1278,80 & 2948,00 \\
& adubação & 222,98 & 13,94 & 183,00 \\
& part. \% & 14,5 & 10,6 & 6,2 \\
\hline
\end{tabular}

fonte: ANDA (1996).

O custo deste insumo, associado a preços relativamente baixos dos produtos agrícolas, constituem fatores determinantes de sua utilização por parte dos produtores que não possuem sistemas modemos de produção (DIESEL, 1996).

Outro aspecto influenciador da demanda de fertilizantes é a oferta de crédito rural. Este, que na década passada chegou a atingir valores de US\$12 bilhões, foi reduzido a somente US\$2 bihões no início dos anos 90 .

A participação dos fertilizantes no custo operacional e no custo total (considera renda de todos os fatores) da cultura do milho na safra de verão 95/96, região Centro-sul, assim como os dispêndios efetivos por hectare com aquisição de fertilizantes podem ser verificados na tabela 4.2. A receita bruta ${ }^{3}$ por unidade de área estimada para o cereal oscilou entre US $\$ 414,40$ e US $\$ 539,00$ no periodo $1989-95$. Foi de $23,7 \%$ a média de participação do custo de adubação no período $89-95$, ressaltando que este item teve um peso maior em relação à receita bruta que em outra culturas 
como a soja $(13,3 \%)$, cana-de-açúcar $(12,7 \%)$, trigo $(17,2 \%)$, arroz $(12,6 \%)$ e café $(11,8 \%)$ (TSUNECHIRO \& FERREIRA, 1996).

Tabela 4.2. Participação dos fertilizantes no custo operacional e total da cultura do milho.

\begin{tabular}{c|ccc}
$\begin{array}{c}\text { produtividade } \\
\text { (kg/ha) }\end{array}$ & \% c. operacional & \% c. total & $\begin{array}{c}\text { dispêndio efetivo } \\
\text { R } \$ \text { /ha* }\end{array}$ \\
\hline 3000 & 21,7 & 18,2 & 86,92 \\
4500 & 22,1 & 19,1 & 117,52 \\
5500 & 23,8 & 20,8 & 143,26 \\
*valores de $04 / 96$, câmbio: $R \$ / U S \$=0,9899$ (dólar oficial) &
\end{tabular}

fonte: TSUNECHIRO \& FERREIRA (1996).

Segundo TSUNECHIRO \& FERREIRA (1996), a relação de preços (relação de troca) adubo/milho tem se mostrado um fator de influência no consumo de fertilizantes pelo agricultor. Esta posição desfavorável do cereal é consequência da baixa produtividade média da cultura em virtude da predominância do que os autores consideraram como áreas cultivadas com baixo nivel tecnológico. Nos últimos dois anos esta relação tem piorado para o produtor da região centro-sul em função da queda dos preços do cereal.

\subsubsection{Oferta e Consumo de Sementes de Adubo Verde}

A Associação Brasileira dos Produtores de Sementes (ABRASEM, 1997) não fornece em seu anuário dados relativos à produção nacional de sementes de leguminosas destinadas à prática da adubação verde. Os únicos números que estariam ligados à produção destas sementes seriam os de produção de sementes para forragens, onde se incluem várias espécies destinadas à produção de massa verde, como o próprio nome já define. Entre elas, encontram-se algumas espécies definidas como adubos verdes, entretanto, este " $m i x$ " varia de estado para estado, quando não é inexistente; esta situação dificulta ainda mais 0 reconhecimento destes números como representativos da disponibilidade de sementes de adubo verde no mercado.

A titulo de informação, a tabela 4.3 registra a quantidade produzida de sementes para forragens na safra 95/96, e sua respectiva percentagem em relação ao total produzido em cada estado. 
Tabela 4.3. Produção de sementes para forragens.

fonte: ABRASEM (1997).

\begin{tabular}{|r|r|r|}
\hline $\begin{array}{r}\text { associações estaduais de } \\
\text { produtores de sementes }\end{array}$ & $\begin{array}{r}\text { produção de } \\
\text { sementes (t) }\end{array}$ & $\begin{array}{r}\% \text { em relação ao } \\
\text { total produzido }\end{array}$ \\
\hline APASSUL-RS & 16522 & 4 \\
\hline APROSEC-SC & 790 & 1 \\
\hline APASEM-PR & 3722 & 1 \\
\hline APPS-SP & 25000 & 27 \\
\hline APSEMG-MG & 5228 & 4 \\
\hline APROSSUL-MS & - & 0 \\
\hline APROMAT-MT & - & 0 \\
\hline AGROSEM-GO & 19908 & 14 \\
\hline APRAS-DF & - & 0 \\
\hline
\end{tabular}

COSTA et al. (1993) afirmam que o envolvimento de produtores e/ou cooperativas interessados na produção de sementes para adubação verde é muito pequeno, no estado de Santa Catarina, apesar da elevada demanda. Tanto o recebimento como a comercializaçăo em casas comerciais, cooperativas ou mesmo intercâmbio entre produtores têm sido realizados sem controle oficial e o produto vendido elou recebido, considerado como "grão".

0 autor fornece dados de recebimento e comercialização de adubos verdes em algumas cooperativas da região Oeste Catarinense (tabela 4.4), registrando que, antes de 1987, as informações são praticamente inexistentes.

Tabela 4.4. Comercialização de sementes para adubação verde por cooperativas em SC.

\begin{tabular}{l|r|r|l|l|r} 
espécies & Cooperalfa & Coperdia & $\begin{array}{l}\text { C.A. } \\
\text { Videirense }\end{array}$ & Coopercampos & \multicolumn{1}{l|}{ Total } \\
\hline & $t$ & $t$ & $t$ & $t$ & $t$ \\
\hline aveia-preta & 127,0 & 62,5 & 12,5 & 0,0 & 202,0 \\
\hline chincho & 37,1 & 1,1 & 3,0 & 0,0 & 41,2 \\
\hline ervilha do campo & 12,1 & 2,6 & 0,7 & 0,0 & 15,4 \\
\hline nabo forrageiro & 0,0 & 0,0 & 0,2 & 0,0 & 0,2 \\
\hline serradela & 0,0 & 0,0 & 0,7 & 0,0 & 0,7 \\
\hline tremoço & 8,2 & 0,0 & 0,0 & 0,0 & 8,2 \\
\hline vica comum & 104,8 & 29,0 & 5,0 & 108,3 & 247,0 \\
\hline vica peluda & 3,7 & 0,0 & 0,0 & 0,0 & 3,7 \\
\hline total no periodo & 292,7 & 95,1 & 22,0 & 108,2 &
\end{tabular}

fonte: COSTA et al. (1993). 
Santa Catarina tem- se caracterizado como importadora de sementes de adubos verdes de verão e grande exportador de adubos verdes de inverno para o Paraná e Rio Grande do Sul. Não é raro encontrar representantes de grandes empresas comercializadoras de sementes, contatando cooperativas agricolas e até mesmo produtores para aquisição de adubos verdes de inverno e posterior revenda no local de origem (COSTA et al.,1993). Neste estado, a empresa de pesquisa estadual EMPAGRI, a partir do ano agricola 83/84, iniciou um programa de produção de sementes básicas de adubos verdes de verão.

No relatório "SUBSÍDIOS À FORMULAÇÃO DE POLITICA SOBRE O USO DA MATÉRIA ORGÂNICA NA AGRICULTURA PAULISTA", constatou-se a necessidade de se atrelar a disseminação da prática de adubação verde ao aumento da oferta desta qualidade de sementes ao setor produtivo. A baixa oferta de sementes foi considerada o ponto de estrangulamento da expansão desta prática, constatando que a Secretaria de Abastecimento e Agricultura deste estado já vinha atuando nesta área, carecendo apenas de implementação do projeto.

CHABARIBERY (1988) identificou restrições encontradas pelos agricultores para a utilização da adubação verde no Estado de São Paulo, dentre elas, a falta de sementes de leguminosas frequentemente utilizadas em rotação de culturas, como a mucuna-preta (Stizolobium aterrium), o lab-lab (Dolichos lab-lab), o feijão-de-porco (Canavalia ensiformes) e o guandu (Cajanus cajart).

A Coordenadoria de Assitência Técnica Integral-CATI, órgão da Secretaria de Agricultura e Abastecimento do Estado de São Paulo, tem um controle anual da produção de sementes fiscalizadas. Para o ano agricola 1996/97, em São Paulo, de acordo com o mapa anual da produção de sementes, a oferta de sementes de adubo verde fiscalizadas foi zero ${ }^{4}$.

O projeto LUPA (1997), também da SAA do estado de São Paulo, revelou que, das 277.124 unidades de produção agricola pesquisadas-UPAS (equivalente a $19.999 .484 \mathrm{ha}$ ), $30 \%$ revelaram utilizar a adubação verde ou orgânica quando necessário. Caso se considere a UPA com tamanho médio de 72 ha, tem-se 6.109 .344 ha empregando fontes alternativas de nutrientes para as culturas comerciais. Através da pesquisa, não existe a separação entre adubação verde e orgânica, o que impede a execução de uma estimativa de consumo de sementes de adubo verde.

Uma observação pode ser feita quando se comparam os dados registrados de comercialização destas sementes e os dados dos agricultores que revelaram empregar tal técnica:

${ }^{4}$ comunicação pessoal: Engenheiro Agrônomo Paulo Cesar Mendes, funcionário da CATI, Campinas, agosto de 1998. 
pode existir um comércio de sementes não fiscalizadas, que não é registrado pelo órgão fiscalizador, assim como os agricultores podem estar produzindo sua própria semente, gerando ou não um comércio entre agricultores.

O "I LEVANTAMENTO AGROECOLÓGICO DO ESTADO DE SÃO PAULO" (AAO, 1992) cadastrou 63 experiências produtivas consideradas orgânicas. As propriedades cadastradas totalizaram 6.500 ha. 0 estudo identificou que $23 \%$ dos produtores cadastrados utilizam algum tipo de fertilizante mineral e $62 \%$ utilizam adubos verdes.

\subsection{Medidas para Racionalizar o Uso de Fertilizantes Minerais Nitrogenados}

\subsubsection{Aplicacão Eficiente de Fertilizante Mineral Nitrogenado}

Este item irá fornecer informações gerais referentes à necessidade de nitrogênio pelas culturas, dinâmica dos fertilizantes quando aplicados ao solo e uma revisão bibliográfica sobre os efeitos do tipo de aplicação do fertilizante mineral nitrogenado. Esta revisão será a base para a formulação da hipótese a ser avaliada através da construção de cenários de demanda de nitrogênio. Considera-se, mais especificamente, que a aplicação eficiente do fertilizante nitrogenado em cobertura seja uma medida de conservação de insumo/energia.

O nitrogênio não tem ainda um critério definitivo de recomendação de adubação através da análise quimica do solo. A maioria das recomendações baseia-se na expectativa da produção, no teor de matéria orgânica do solo, no histórico da área e em curvas de resposta em relação a várias dosagens de nitrogênio (YAMADA, 1995). Tais recomendações são fundamentadas na hipótese de que a matéria orgânica irá liberar o nitrogênio em tempo hábil para utilização pelas plantas, juntamente com o nitrogênio fomecido pelos fertilizantes, cobrindo, assim, as necessidades para a colheita esperada.

VITTI et al. (1984) ressaltam a importância de se conhecer o comportamento dos fertilizantes no solo para se alcançar alta eficiência na adubação. Faz, então, uma breve apresentação do tema.

- Uréia

Microorganismos do solo, pela atividade da urease (enzima), transformam rapidamente a uréia em carbonato de amônio que se decompõe espontaneamente resultando em amônia e gás carbônico: 


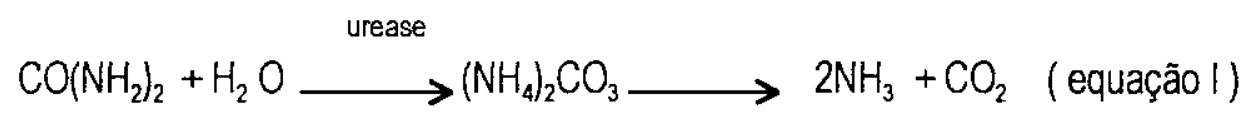

$\mathrm{O} \mathrm{NH}_{3}$ formado pode seguir os seguintes caminhos:

a) perder-se por volatilização, particularmente nas adubações de cobertura.

b) reagir com a água:

$$
\begin{gathered}
2 \mathrm{NH}_{3}+\mathrm{H}_{2} \mathrm{O} \\
\mathrm{pH}>7,0
\end{gathered} \underset{\mathrm{NH}_{4}^{+}+\mathrm{OH}^{-} \text {(equação II) }}{\mathrm{pH}<7,0}
$$

$\mathrm{O} \mathrm{NH}_{4}^{+}$por sua vez poderá:

a) principalmente sofrer nitrificação:

$$
\begin{aligned}
& 2 \mathrm{NH}_{4}^{+}+3 \mathrm{O}_{2} \longrightarrow 2 \mathrm{NO}_{2}^{-}+2 \mathrm{H}_{2} \mathrm{O}+\mathrm{E} \text { (equação } \| \mathrm{II} \text { ) } \\
& 2 \mathrm{NO}_{2}^{-}+\mathrm{O}_{2} \longrightarrow 2 \mathrm{NO}_{3}^{-}+\mathrm{E}(\text { equação I V) }
\end{aligned}
$$

b) ser adsorvido ao complexo de troca. ${ }^{5}$

c) ser absorvido pelas raízes.

\section{- Sulfato de amónio}

Em condições normais $0 \mathrm{NH}_{4}^{+}$do sulfato de amônio é retido temporária e superficialmente pelo complexo coloidal, passando depois para a solução do solo onde sofre o processo de nitrificação (equações III e IV). Normatmente, a nitrificação se dá de modo mais ou menos rápido, variando de cinco até quinze dias para atingir uma taxa de nitrificação de 60 a $80 \%$.

$\mathrm{ON}-\mathrm{NO}_{3}^{-}$pode seguir os seguintes caminhos:

a) principalmente ser perdido por lixiviação.

b) ser absorvido pelas raizes e microorganismos.

c) sofrer desnitrificação.

\footnotetext{
${ }^{5}$ Formado por particulas de solo menores que 2 micra minerais e/ou orgânicas e que apresenta um balanço de cargas negativas. Isto significa que são capazes de reter particulas com cargas positivas, como por exemplo, vários nutrientes na forma de cátions, o que impede a sua lixiviação, permitindo que as raizes os absorvam.
} 
A desnitrificação (equação V) é a redução biológica do nitrato $\left(\mathrm{N}-\mathrm{NO}_{3}\right)$ ou nitrito $\left(\mathrm{N}-\mathrm{NO}_{2}{ }^{-}\right)$à formas gasosas de nitrogênio. $\dot{E}$ realizada por bactérias anaeróbicas facultativas sendo favorecida pela ausência de oxigênio, teor alto de MO e presença de nitrato no solo.

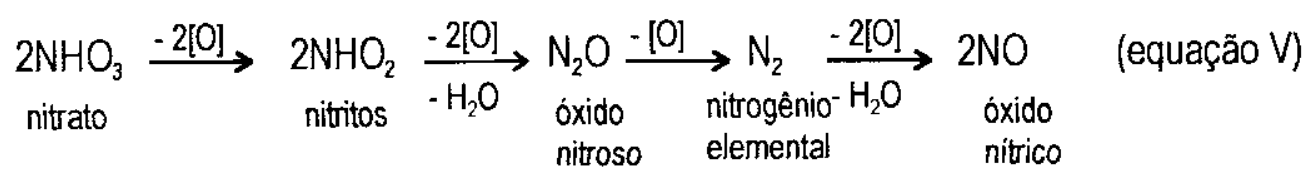

MACHADO (1997) afirma que a quantidade de óxido nitroso emitida depende da quantidade de fertilizante mineral nitrogenado empregada, do tipo do produto $\left(\mathrm{NO}_{3}\right.$ ou $\left.\mathrm{NH}_{4}\right)$ e das condições do solo. As emissões correspondem a 0,5 a $1,5 \%$ do FMN aplicado, onde o maior valor é encontrado para fertilizantes contendo $\mathrm{NH}_{4}^{+}$.

Assim como no caso da uréia, o sulfato de amônio leva a uma acidificação do solo, seja pelo processo da nitrificação, seja pela lixiviação do $\mathrm{Ca}+$ pelo $\mathrm{NO}_{3}{ }^{-}$ou $\mathrm{SO}_{4}^{-}$

\section{- Nitrato de amônio e nitrocálcio}

Nestes dois produtos, metade do nitrogênio está na forma nitrica e metade na amoniacal. 0 nitrogênio amoniacal sofre as transformações já discutidas, enquanto o nitrogênio nítrico estará sujeito principalmente a perdas por lixiviação.

Tradicionalmente, a adubação nitrogenada no Brasil, para culturas anuais, é feita da seguinte maneira: aplicação de uma pequena quantidade de nitrogênio (1/3) por ocasião da semeadura, e uma quantidade maior, posteriormente, em cobertura (2/3), quando o sistema radicular das plantas já estiver suficientemente desenvolvido para absorver o nutriente aplicado.

Das fontes de nitrogênio encontradas no comércio para as aplicações em cobertura, a uréia é em geral a mais barata, encontrada em maior disponibilidade no mercado brasileiro, e portanto, a mais utilizada para este fim (YAMADA, 1996). A prática mais comum empregada pelos agricultores na aplicação do produto é simplesmente distribuir o fertilizante na superfície do solo.

\subsubsection{Potencial de Economia de FMN através da sua Incorporacão ao Solo}

Apesar de ser o mais importante adubo nitrogenado no país, o aproveitamento do nitrogênio da uréia é muitas vezes comprometido principalmente devido a perdas por volatilização. A 
incorporação da uréia ao solo é uma prática efetiva na diminuição destas perdas, porém, é ainda pouco utilizada (VILLAS BOAS et al., 1993).

A incorporação do fertilizante prescinde de um implemento, que pode ser o comercial movido tanto a tração motora quanto animal, ou implementos desenvolvidos regionalmente e até na própria propriedade.

As condições que propiciam volatilização de $\mathrm{NH}_{3}$ do solo são a alcalinidade, temperatura elevada, baixa capacidade de retenção de amônia, a qual está associada a solos arenosos e pobres em matéria orgânica (solos com baixa $\mathrm{CTC}^{6}$ ), altas doses de uréia, aplicação na superficie úmida que depois seca (KIEHL, 1980 apud VITTI et al., 1984).

LOPES \& GUILHERME (1992) também afirmam que a incorporação adequada dos fertilizantes nitrogenados, tanto por ocasião do plantio, como no caso das coberturas, resulta em significativa redução das perdas por volatilização da amônia. Aplicação de fertilizantes na forma amídica (uréia) e amoniacais (sulfato de amônio) deve ser feita em sulco, cobrindo-se o fertilizante com aproximadamente $5 \mathrm{~cm}$ de terra ou misturando-se o fertilizante com a camada superficial do solo. Os gráficos 4.6 e 4.7 ilustram os efeitos de tal prática em um experimento efetuado com a cultura do milho e diferentes doses de ureia (LOPES \& GUILHERME, 1992).

Gráficos 4.6 e 4.7. Absorção de $N$ por plantas de milho em dois solos diferentes e diferentes modos de aplicação de uréia.

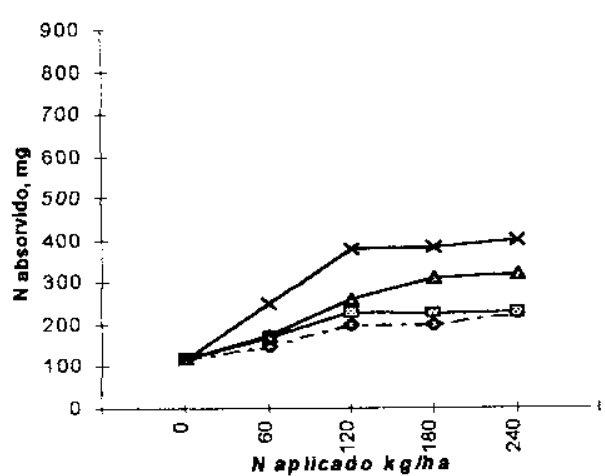

podzólico vermelho amarelo

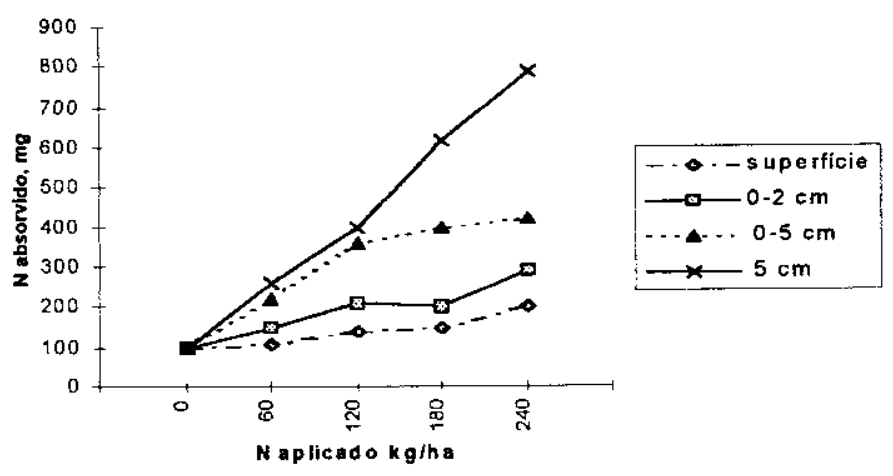

latossolo vermelho-amarelo distrófico

fonte: LOPES \& GUILHERME (1992). 
De DATTA et al. (1968) apud PRASAD (1986) utilizando nitrogênio marcado observaram que a produtividade do arroz e a taxa de utilização do nitrogênio apresentaram os melhores resultados quando este foi incorporado a $10 \mathrm{~cm}$ de profundidade.

Segundo YAMADA (1995), existem duas hipóteses para a reduzida eficiência da adubação nitrogenada em cobertura: perdas gasosas e/ou imobilização biológica. $O$ autor cita um trabalho onde identificaram-se perdas de $24 \%$ do $\mathrm{N}$ da uréia por volatilização quando esta foi aplicada em superficie e, quando de sua incorporação ao solo, observou-se redução considerável desta perda.

Medições feitas em condições de campo em milho mostraram perdas entre 12 e $30 \%$ do $\mathrm{N}$ uréia aplicado na superficie dos solos, mas estas se reduzem quando a uréia é incorporada (ANJOS \&TEDESCO, 1974; CANTARELLA et al.,1988).

ERNST \& MASSEY (1960) apud VITTI et al. (1984) demonstraram os efeitos da profundidade nas perdas de amônia por volatilização (gráfico 4.8).

Gráfico 4.8. Efeitos da profundidade de aplicação do fertilizante nas perdas por volatilização.

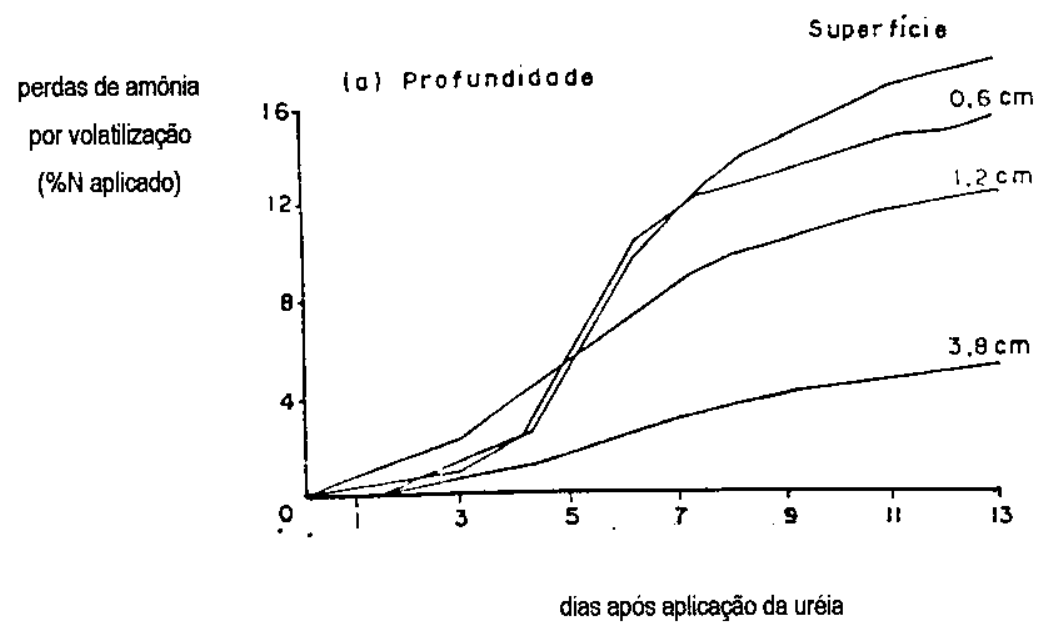

fonte: ERNST \& MASSEY (1960) apud VITTI et al. (1984).

RAIJ (1993) e a própria Associação Nacional para Difusão de Adubos e Corretivos - ANDA em suas publicações técnicas, também ressaltam a importância de se incorporar o adubo nitrogenado em cobertura, principalmente a uréia.

BARRETTO et al. (1992) verificaram que, em um solo Latossolo Roxo álico, testando a aplicação de uréia em diferentes profundidades e niveis de umidade, as maiores perdas foram de $0,5 \%$ do nitrogênio quando aplicado em superfície. Quando a uréia foi incorporada a 2,5 e $5,0 \mathrm{~cm}$ de profundidade, as perdas foram praticamente nulas. 
As perdas de amônia, através da aplicação de uréia no solo Areia Quartzosa distrófica em superficie, atingem até $62,2 \%$. 0 aprofundamento da aplicação provocou reduções significativas nas perdas, mas não foi suficiente para eliminá-las (BARRETTO et al., 1992).

TRIVELIN et al. (1993) em um experimento com diferentes fertilizantes nitrogenados estudaram o efeito de aplicá-los em superficie nas perdas de $\mathrm{N}$-amônia por volatilização (tabela 4.5).

Tabela 4.5. Perdas acumuladas de $\mathrm{N}$-amônia $(\% \mathrm{~N})$ associadas à aplicação superficial de Uréia, Nitrato de amônio (NA) e Uran em dois solos e em três umidades iniciais do solo $(\mathrm{Ug} / 100 \mathrm{~g})$.

\begin{tabular}{|r|r|r|r|r|r|r|r|}
\cline { 2 - 7 } \multicolumn{1}{c|}{} & \multicolumn{5}{|c|}{ latossolo roxo } & \multicolumn{3}{r|}{ areia quartzosa } \\
\hline umidade & $U=12,1$ & $U=22$ & $U=31,7$ & $U=10,4$ & $U=20$ & $U=29,6$ \\
\hline fertilizante & & \multicolumn{5}{c}{$\%$-fertillizante } \\
\hline uréia & $2,5 \mathrm{a}$ & $30,1 \mathrm{a}$ & $28,8 \mathrm{a}$ & $65,4 \mathrm{a}$ & $55,4 \mathrm{a}$ & $42,4 \mathrm{a}$ \\
\hline $\mathrm{NA}$ & $4,2 \mathrm{a}$ & $4,2 \mathrm{~b}$ & $1,7 \mathrm{~b}$ & $5,0 \mathrm{c}$ & $1,6 \mathrm{c}$ & $0,5 \mathrm{c}$ \\
\hline Uram & $4,9 \mathrm{a}$ & $4,7 \mathrm{~b}$ & $7,3 \mathrm{~b}$ & $19,5 \mathrm{~b}$ & $23,7 \mathrm{~b}$ & $14,6 \mathrm{~b}$ \\
\hline
\end{tabular}

médias seguidas de mesma letra na coluna não diferem estatisticamente pelo teste de Duncan $(p=0,05)$.

fonte: TRIVELIN et al. (1993).

CANTARELLA et al. (1994), entretanto, não encontraram diferença no rendimento do milho quando testaram a aplicação de uréia em superfície e incorporada.

LARA et al. (1994) encontraram perdas de amônia por volatilização provenientes da adubação superficial de cobertura com uréia, em milho, variando de $23,3 \%$ do $\mathrm{N}$-amônia acumulado entre 2 a 4 dias após a aplicação até $57 \%$ do $\mathrm{N}$-amônia acumulado entre 40 a 42 após a aplicação. Os autores concluiram que aumentos de produtividade na cultura do milho devem passar pelo conhecimento e controle das perdas nitrogenadas, sendo necessário o desenvolvimento de implementos de aplicação que permitam aprofundar o adubo para o seu melhor aproveitamento pela cultura.

\subsubsection{Adubacão Verde}

A capacidade de fixar nitrogênio biologicamente è restrita aos seres vivos primitivos, principalmente as bactérias. Mesmo assim, somente as denominadas diazotróficas possuem tal caracteristica. Sob o enfoque da agricultura, as diazotróficas mais importantes são aquelas que fixam o nitrogênio em associação com uma planta superior, porque o nutriente é fixado próximo às raizes das plantas.

As associações agronomicamente mais importantes, entretanto, são entre leguminosas e espécies de bactérias do gênero Rhizobium, porque formam o sistema mais perfeito capaz de 
substituir os processo químicos de redução do $\mathrm{N}_{2}$ e produção de fertilizantes. Porém, não são todas as leguminosas que possuem bactérias noduladoras e também existem, em menor intensidade, outras plantas não leguminosas capazes de proporcionar tal associação simbiótica.

Um dos maiores desafios da pesquisa agropecuária nos últimos anos tem sido o de desenvolver a capacidade de fixação biológica de nitrogênio para cereais e outras gramineas através de tentativas de transferir a fixação biológica do $N$ diretamente para estas plantas superiores, ou somente identificar e manipular associações já existentes de bactérias fixadoras de $\mathrm{N}_{2}$ com gramíneas (DOBEREINER, 1990). Destacam-se entre as culturas pesquisadas no Brasil, a soja, o feijão, leguminosas forrageiras, a cana-de-açucar e os cereais como trigo, milho e sorgo.

Para DOBEREINER (1990), a importância econômica da pesquisa em fixação biológica do nitrogênio, para o Brasil, pode ser exemplificada pelos resultados obtidos com a soja que, por causa do melhoramento vegetal e seleção de rizóbios adaptados para as condições brasileiras, chegou a dispensar qualquer adubo nitrogenado e, com isto, retorna anualmente ao sistema solo planta um montante de $\mathrm{N}$ equivalente a US $\$ 1,5$ bihões.

Enquanto a indústria de fertilizantes utiliza para cindir a molécula de $\mathrm{N}_{2}$ altas temperaturas e altas pressões e mais um catalisador contendo ferro, as bactérias fixadoras, utilizando-se de temperatura ambiente, da pressão de uma atmosfera e uma enzima (nitrogenase) como catalisador, realizam a fixação biológica simbiótica desse nutriente (figura 4.1). A enzima denominada nitrogenase é o componente que age como catalisador da redução do nitrogênio em amônia. A simbiose ocorre com o suprimento de água e carboidratos da planta para a bactéria e gás carbônico da atmosfera. A bactéria excreta amônia (o primeiro produto resultante da reação com a nitrogenase). A amônia é convertida em uma variedade de aminoácidos que são secretados no sistema de condução da seiva vegetal na planta, o xilema. A planta, então, utiliza tais substâncias no seu desenvolvimento (POSTGATE ,1989). 
Figura 4.1. Processo de fixação do nitrogênio no interior da bactéria.

fonte: VITTI et al. (1984).

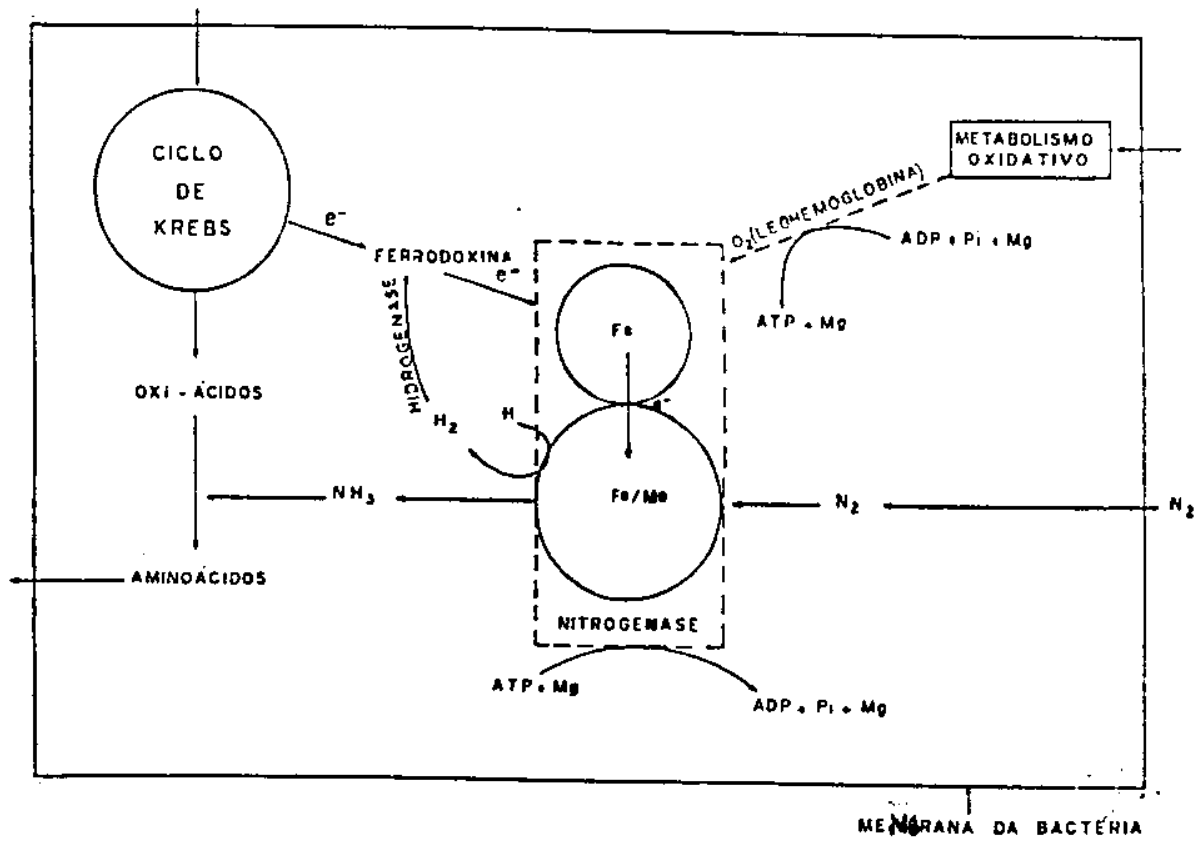

A. adubação verde é uma prática milenar que deixou de ser utilizada pelos agricultores com a expansão do uso dos fertilizantes minerais, onde são utilizados vegetais capazes de estabelecer a associação simbiótica com as bactérias para proporcionar, principalmente, o fornecimento de nitrogênio.

PIETERS (1927) apud OLIVEIRA (1996) define adubação verde como sendo a prática de enriquecimento do solo pela incorporação, ou não, de plantas apresentando material não decomposto, exceto residuo de colheita, oriundo ou trazido de outro local. Segundo COSTA et al. (1993), pode-se conceituar adubação verde como a utilização de plantas em rotação, sucessão ou consorciação com as culturas, incorporando-as ao solo ou deixando-as na superficie.

A massa vegetal sofrerá um processo de decomposição, onde os diversos organismos do solo, quer animais quer vegetais, atacam os compostos orgânicos nitrogenados. Como resultado da digestão enzímica, as proteinas mais complexas e seus compostos associados são simplificados e hidrolisados e o produto final é a amônia.

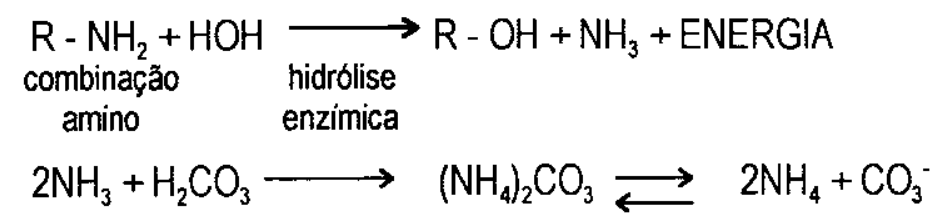

Apesar do fornecimento de nitrogênio ser o principal objetivo, esta prática desempenha um conjunto de outras ações integradas que trazem grandes beneficios aos sistemas agricolas, como: 
- proteção do solo contra os agentes da erosão e incidência de raios solares.

- suprimento de matéria orgânica ao solo.

- descompactação, estruturação e aeração do solo.

- melhoria do aproveitamento e eficiência dos adubos e corretivos.

- fixação de nitrogênio direto da atmosfera e posterior disponibilização para culturas comerciais.

- fornecimento de fitomassa para formação da cobertura morta.

- redução da infestação de plantas invasoras através de efeito alelopático ${ }^{7}$ ou do efeito físico da cobertura morta que impede a germinação destas espécies.

- controle de nematóides.

- aumento da capacidade de armazenamento de água no solo.

- atenuação da variação térmica do solo.

- recuperação de solos de baixa fertilidade.

Estes beneficios, por sua vez, geram aumento da receita devido ao do ganho de produtividade e melhoria na qualidade do produto.

Pelo combate à erosão e melhoria dos atributos físicos, químicos e biológicos do solo, a adubação verde torna-se um fator importante de preservação do solo.

A redução do custo de produção é outro resultado positivo da adoção desta prática em consequência da economia no consumo de adubo mineral nitrogenado e da redução da utilização de herbicidas e nematicidas.

Em uma pesquisa feita no Estado de São Paulo (CHABARIBERY, 1988) com agricultores que adotaram a prática da adubação verde, eles declararam que sua motivação para mudar foi "porque 0 adubo verde evita doenças elou pragas". Estão também interessados em "produzir com retomo econômico", além da preocupação na "recuperação e conservação da vida do solo" através do combate à erosão com a adição de matéria orgânica.

Para fazer parte de um determinado sistema de cultivo, uma espécie destinada à adubação verde precisa ser criteriosamente avaliada regionaimente, tanto em termos do seu comportamento quanto em seus diferentes potenciais de aproveitamento. WUTKE (1993) ressalta a importância de se observar as caracteristicas dos sistemas de produção vigentes na região específica. Para se escolher e utilizar determinada espécie deve-se observar a não interferência com as principais

\footnotetext{
${ }^{7}$ Efeito tóxico de algumas plantas sobre outras provocado por compostos químicos, e que recentemente tem sido explorado para o controle de plantas invasoras.
} 
atividades agropecuárias, o custo financeiro dessa prática, a disponibilidade de sementes no mercado, e a preferência do agricultor (em função de seu histórico e conhecimentos especificos).

Os efeitos econômicos da adoção da adubação verde e rotação com milho e amendoim nas culturas do algodão e soja, na região de Ribeirão Preto-SP, mostraram que houve o dobro do retorno em relação aos agricultores que não adotaram a inovação. Isto ocorreu em função de ganhos de rendimento que variaram de $5 \%$ para o algodão a $45 \%$ para o milho e, tambèm, pela redução dos gastos com insumos - $35 \%$ para milho e $25 \%$ para soja (MARTIN et al., 1982).

Assim como qualquer outra cultura, o bom desempenho da adubação verde dependerá de fatores climáticos, edáficos, nutricionais e agronômicos. Uma caracteristica de quem adota tal prática é que deve se adaptar a um sistema de produção diferente daquele onde a fonte de nitrogênio é proveniente de fertilizante mineral nitrogenado. Tal fato pode, muitas vezes, ser considerado como um impedimento à adoção da tecnologia, pois requer algum esforço adicional quando da implementação da mesma.

Existem inúmeras espécies de adubos verdes adaptadas a praticamente todas as regiões brasileiras, o que se traduz em um amplo potencial de adoção da técnica. Além disso, a adubação verde pode ser introduzida no sistema de produção agricola de diversas maneiras, o que impossibilita a criação de um "pacote agrícola", isto è, uma regra única de utilização e manejo da técnica.

\subsubsection{Potencial de Fornecimento de Nitrogênio através da Adubacão Verde}

Como a hipótese construida nos cenários de demanda de nitrogênio está baseada nos dados encontrados na literatura, faz-se necessário indicar alguns resultados obtidos com a utilização da adubação verde como fonte de nitrogênio. É com este objetivo que as próximas citações foram inseridas.

A tabela 4.7 permite visualizar a capacidade de fornecimento de nitrogênio através de diversas leguminosas. 
Tabela 4.7. Capacidade de fornecimento de nitrogênio das leguminosas.

\begin{tabular}{|c|c|}
\hline Jeouminosas & $\mathrm{N}(\mathrm{ka} / \mathrm{ha} / \mathrm{anol}$ \\
\hline Alfafa (Medicaon sativa) & 127 a 133 \\
\hline Amendoim (Arachis hroogoea) & 33 a 297 \\
\hline Calopogônio ( Calopogonium mucunoides) & $64 a 450$ \\
\hline Caupi ( Vigna sinensis) & 73 a 240 \\
\hline Centrosema (Centrosema pubescens) & 93 a 398 \\
\hline Crotalária (Crotalána junceal.) & 150 a 165 \\
\hline Cuzdu topical (Pueraria phaseoloides) & 100 \\
\hline Desmodio (Desmodium spl & 70 \\
\hline Ervilha (Pisum sativum) & 81 a 148 \\
\hline Ervithaca comum (Vicia sativa) & 90 \\
\hline Envilhaca peluda (Vicia villosa) & 110 a 184 \\
\hline Estilosantes (Stylosanthes sp) & 30 a 196 \\
\hline Fava (Vicia faba) & $88 \mathrm{a} 157$ \\
\hline Feiläo de porco (Canavalia ensiformis) & 57 a 190 \\
\hline Galácia (Galacia striata) & 181 \\
\hline Grão de bico (Cicer arieyinumb. & 41 a 270 \\
\hline Guandu (Caianus caiam) & 41 a 90 \\
\hline Guar (Cyamopsis psoraloides) & 37 a 196 \\
\hline Lentilha (Lens culinaria) & $35 a 77$ \\
\hline Lespedeza (Lespedeza stipulsacea). & $193 \ldots \ldots$ \\
\hline Leucena (Leucaena leucocephala) & 400 a 600 \\
\hline Mucuna preta (Mucuna aterima) & 157 \\
\hline Soja perene (Neonotonia wighth & 160 a 450 \\
\hline Soja (Glycine max) & 17 a 369 \\
\hline Siratro (Macroptilium atropurpureum) & 70 a 181 \\
\hline Tremoco (Lupinus SP.) & $128 \ldots \ldots$ \\
\hline Trevo branco (Trifolium repens) & 128 a 268 \\
\hline Trevo doce (Melilotus alba) & $9 a 140$ \\
\hline Trevo eqipcio (Trifolium alexandrinumd) & $62 \mathrm{a} 235$ \\
\hline Trevo vermelho (Trifolium pratense) & 17 a 191 \\
\hline Trevo subtertâneo ( Trifolium subtertaneumt & 21 a 207 \\
\hline
\end{tabular}

fonte: COSTA (1995).

DE-POLLI \& CHADA (1989) realizaram um experimento em ltaguaí,RJ onde foi possivel verificar a capacidade de fornecimento de nitrogênio por diferentes tipos de vegetação. Em ordem decrescente, o feijão-de-porco (Canavalia ensiformis) forneceu anualmente, $107,5 \mathrm{~kg} \mathrm{~N} / \mathrm{ha}$; a mucuna-preta (Mucuna aterrima) $86 \mathrm{~kg} \mathrm{~N} / \mathrm{ha}$; a vegetação espontânea $24,4 \mathrm{~kg}$ N/ha e a crotalária (Crotalaria junced) $22,8 \mathrm{~kg}$ N/ha. Além disso, a tabela 4.8 fornece os dados de produtividade do milho mediante o uso de fertilizante químico ou adubação verde como fonte de nitrogênio. Observase que o fomecimento de $\mathrm{N}$ através da adubação verde com mucuna-preta resultou em uma produtividade semelhante à produtividade alcançada com o fornecimento de $\mathrm{N}$ pela fonte mineral, incorporando ou não o material vegetal ao solo. No caso da associação dos adubos verdes crotalária/feijão-de-porco, quando o material vegetal foi incorporado ao solo, o milho atingiu produtividade superioir à atingida com o fornecimento de $\mathrm{N}$ pela fonte mineral e inferior quando $\mathrm{O}$ material vegetal não foi incorporado ao solo. 
Tabela 4.8. Produção de milho (kg/ha) das safras de 1986, 1987 e 1988 mediante diferentes fontes de nitrogênio.

\begin{tabular}{|c|c|c|c|c|}
\hline \multirow[b]{2}{*}{ safras } & \multicolumn{3}{|c|}{ producão $\mathrm{kg} / \mathrm{ha}$} & \multirow[b]{2}{*}{ média } \\
\hline & 1986 & 1987 & 1988 & \\
\hline \multicolumn{5}{|l|}{ tratamentos } \\
\hline \multicolumn{5}{|l|}{ incorporado } \\
\hline mucuna-preta & 2001 & 2178 & 2120 & $2100 \mathrm{bc}$ \\
\hline crotalária/feijäo-de-porco & 2359 & 3296 & 2930 & 2861 a \\
\hline veg. espontânea & 1312 & 1472 & 1324 & $1369 \mathrm{~d}$ \\
\hline veg. espontânea $+N$ & 2306 & 2517 & 2243 & $2355 \mathrm{~b}$ \\
\hline capina & 895 & 854 & 913 & $887 \mathrm{e}$ \\
\hline média & 1775 & 2063 & 1906 & 1915 \\
\hline \multicolumn{5}{|l|}{ cobertura } \\
\hline mucuna-preta & 2054 & 2151 & 2052 & $2086 \mathrm{bc}$ \\
\hline crotalária/feijâo-de-porco & 1051 & 1926 & 2043 & $1674 \mathrm{~cd}$ \\
\hline veg. espontânea & 594 & 956 & 670 & $740 \mathrm{e}$ \\
\hline veg. espontânea $+\mathrm{N}$ & 2249 & 2669 & 2037 & $2318 b$ \\
\hline capina & 641 & 564 & 502 & $569 \mathrm{e}$ \\
\hline média & 1318 & 1653 & 1461 & 1477 \\
\hline
\end{tabular}

médias na mesma coluna, com a mesma letra, não diferem entre si pelo teste de Duncan a $5 \%$ fonte: DE-POLLI \& CHADA (1989).

PEREIRA FILHO (1996), em um experimento em Sete Lagoas,MG, concluiu que a produção máxima de milho obtida sem a presença da leguminosa leucena (Leucaena leucacephala) e com aplicação de $95 \mathrm{~kg} \mathrm{~N} / \mathrm{ha}$ (5583 kg/ha) foi similar à produção obtida com o nivel zero de nitrogênio de fertilizante mineral e na presença de leucena ( $5566 \mathrm{~kg} / \mathrm{ha})$.

MELO et al. (1994) avaliaram os efeitos da incorporação de massa verde de leguminosas no rendimento do milho por três anos consecutivos, nos municipios de Monsenhor Gil e Paimeirais, $\mathrm{Pl}$. Os autores concluiram que foi significativo o efeito da incorporação no rendimento do milho, proporcionando acréscimos que variaram de 21 a $60 \%$ com relação a testemunha.

ABBOUD \& DUQUE (1993) testaram algumas leguminosas quanto ao seu potencial como fomecedoras de nitrogênio para culturas comerciais no municipio de Itaguai,RJ. Os resultados do trabalho permitem afirmar que é possivel cultivar adubos verdes no período da seca, sem que eles compitam com as espécies comerciais. É possivel também produzir sementes de adubos verdes no período da seca, que podem constituir uma fonte extra de renda ao agricultor e adicionalmente à produção de sementes, è possivel acumular quantidades importantes de matéria orgânica, nitrogênio e outros nutrientes. 
HEINRICHS et al. (1993), em Santa Maria,RS, realizaram um experimento com milho para verificar a eficácia da utilização de diferentes proporções de duas espécies classificadas como adubo verde em comparação com o uso de fertilizante mineral nitrogenado. As espécies utilizadas foram: ervilhaca comum (Vicia sativa) e aveia preta (Avena strigosa). 0 tratamento que empregou somente ervilhaca comum e o que empregou apenas $90 \%$ de ervilhaca mais $10 \%$ de aveia, atingiram produtividades de milho semelhantes às do tratamento no qual a fonte química foi empregada (tabela 4.9).

Tabela 4.9. Rendimento médio do milho sob diferentes tratamentos relacionados a fonte de nitrogênio.

\begin{tabular}{|cc|r|}
\hline \multicolumn{2}{|c|}{$\begin{array}{c}\text { densidade de semeadura } \\
\text { ervilhaca(\%) aveia(\%) }\end{array}$} & milho $\mathrm{kg} / \mathrm{ha}$ \\
\hline 100 & 0 & 5473 \\
\hline 90 & 10 & 4692 \\
\hline 75 & 25 & 3987 \\
\hline 50 & 50 & 3288 \\
\hline 25 & 75 & 3000 \\
\hline 0 & 100 & 2377 \\
\hline \multicolumn{2}{|c|}{ pousio $+\boldsymbol{N}$} & 5101 \\
\hline \multicolumn{2}{|c|}{ pousio sem $\mathbf{N}$} & 3729 \\
\hline
\end{tabular}

fonte: HEINRICHS et al. (1993).

\subsection{Cenários de Demanda de Nitrogênio:}

\section{Um Estudo de Caso da Cultura do Milho no Brasil}

\subsubsection{Metodologia}

“.. Tal teoria nos parace indispensável para dotar a prospectiva com um instrumento suficientemente concreto que permita abordar, a partir dos cenários do possivel, a problemática das estratégias de transição. Insistimos, a propósito, que, contrariamente à futurologia, a prospectiva não se engaja na previsão. O seu papel é de desfatalizar a histónia e derrubar a canga do passado que pesa sobre quem decide. A prospectiva preenche, pois, antes de tudo, uma função pedagógica: força as pessoas a pensarem os futuros e depois inventá-los. 
... Que seja eticamente engajada e que, ao invés de prever o imprevisivel, suscite a reflexão sobre os mecanismos de adaptação que é preciso por em funcionamento para se enfrentar um meio ambiente cada vez mais turbulento." (SACHS, 1986).

A metodologia de construção de cenários DEFENDUS (development-focused end-useoriented service-directed) (ANEXO 4), que tem sido utilizada para o planejamento da demanda direta de energia em diversos setores, pode também, ser empregada para estimar a demanda de um recurso.

Especificamente, será estimada a demanda de nitrogênio e energia derivada do requerimento de FMN para a cultura do milho no Brasil. Em seguida, serão calculados os custos para se atender a esta demanda mediante as opçōes tecnológicas disponiveis.

Optou-se por demonstrar os resultados na forma do nutriente N-FMN (nitrogênio proveniente de fertilizante mineral nitrogenado), ao invés da energia, porque N-FMN é um parâmetro quantitativo mais facilmente compreendido. Entretanto, a dimensão atingida de conservação de energia será também explicitada.

Apesar da agricultura ser um processo dinâmico e dependente da sinergia de uma série de fatores, no caso do nitrogênio é possivel verificar mudanças na produtividade quando só este fator for adicionado em maior quantidade, supondo-se que existirão as condições minimas para 0 aparecimento do seu efeito, como a adoção da prática da calagem.

Na metodologia DEFENDUS, a demanda por um recurso é tratada como o produto do:

(1) número de consumidores ou unidades de produção lou qualquer outra entidade consumidora, como por exemplo, hectares cultivados com milho), $e$

(2) requerimento do recurso por consumidor ou unidade produtiva (diga-se quilogramas do insumo/recurso por hectare).

O número de consumidores em qualquer data futura, depende do número no ano base (situação presente) e da taxa de crescimento utilizada entre o ano base e o período futuro determinado.

A demanda pelo recurso por unidade consumidora ( $\mathrm{kg} \mathrm{N} / \mathrm{ha}$ ) é dependente das tecnologias disponiveis e da eficiência com que o recurso é empregado ao longo do processo produtivo.

Para prover o tomador de decisão de uma base para uma escolha racional entre opções alternativas, pode-se construir vários cenários, cada qual sendo o resultado de uma demanda particular pelo insumo/recurso. $O$ então estimado requerimento pelo insumo deve ser equiparado com suas devidas opções de oferta (ou conservação). 
Para isto, o custo por unidade de produção ou conservação deve ser estimado, e um mix apropriado de alternativas selecionado para atender a demanda ao minimo custo possivel.

Quando um plano de utilização de recursos é construido, as estratégias sugeridas devem ser direcionadas para atender as metas desejadas. Então, se a meta é uma distribuição mais equitativa do recurso, o plano deve escolher estratégias que resultem em mais consumidores tendo acesso a ele. Se a meta é elevar a eficiência do seu uso, o plano tem de promover a maneira mais eficiente de empregá-lo.

Os cenários de demanda de nitrogênio aqui construidos permitem a inclusão de outras fontes de nitrogênio sem ser as provenientes dos FMN, no caso, os adubos verdes. Isto é importante porque, neste contexto, interessa destacar o fato de que a essência de um insumo agricola, qualquer que seja a tecnologia adotada, não é a do insumo em si, mas o efeito benéfico que vai proporcionar ao processo de produção agricola (DULLEY \& MIYASAKA, 1994).

DULLEY \& MIYASAKA (1994), exemplificam:

‘.. Assim, o calcário na realidade, corresponde à correção da acidez do solo; o adubo químico, à absorção de nutrientes em maior volume num reduzido espaço de tempo; um defensivo, à eliminação de uma doença ou praga, e assim por diante.

Por outro lado, na agricultura sustentável, o conjunto e as práticas necessárias, criadas ou desenvolvidas por agricultores ou pesquisadores, capazes de surtir 0 efeito de, por exemplo, neutralizarem os danos de uma praga agrícola, devem ser entendidos como insumo."

Algumas analogias entre este exercicio de planejamento de uso de recursos e aqueles de planejamento energético podem ser efetuadas:

- A quantidade de energia requerida depende do nível de serviços energéticos desejados e da eficiência no uso da energia. Similarmente, o requerimento por N-FMN é determinado pela produção desejada e a efetividade do uso deste insumo.

- Assim como cenários de demanda de energia distinguem entre categorias de consumidores em uma unidade básica (por exemplo, GJ por consumidor), pode-se distinguir entre consumidores de fertilizantes (leia-se área cultivada) na base da quantidade de fertilizante consumido (quilogramas por hectare).

- Assim como para satisfazer a demanda de energia, para atender a demanda estimada de $N$, escolhas racionais devem ser feitas entre opções de produção e/ou conservação. Neste contexto, 
"conservação" implica em evitar o uso desnecessário de fertilizante mineral nitrogenado, sem contudo, diminuir o nivel já alcançado de produtividade da terra.

\subsubsection{Procedimento}

Analisar a inserção de práticas que resultam no uso racional do FMN e verificar o que ocorrerá com a demanda de FMN com a elevação da proporção da área que emprega este insumo são os objetivos da construção dos cenários.

A produção de milho e a correspondente demanda por nitrogênio, $\mathrm{FMN}_{1}$ amônia e energia foram estimadas em intervalos de cinco anos, entre 1995 e 2010 por meio da construção dos seguintes cenários de demanda, onde a área cultivada com milho e sua expansão ao longo do período de análise será a mesma para todos $(0,30 \%$ a.a.):

- Cenário Referência l: cenário no qual a proporção da área com milho que emprega N-FMN e a eficiência de utilização de N-FMN (produção de milho (t)/ N-FMN (t)) não vão mudar durante todo 0 periodo de análise. Este cenário representa o caso-referência do estudo para a comparação com os três cenários contrastados indicados a seguir.

- Cenário Manejo Eficiente l. cenário no qual a proporção da área com milho que utiliza N-FMN será a mesma durante todo o periodo de análise, porém com um aumento da eficiência do uso de $\mathrm{N}$ FMN. Aqui, a medida de conservação de energia/insumo sugerida é a incorporação do N-FMN em cobertura. Este cenário pretende mostrar o resultado de não se difundir a adoção de FMN e o que pode acontecer caso o agricultor passe a adotar práticas que propiciem uma menor perda de FMN.

- Cenário Adubo Verde f. cenário no qual a proporção da área com milho que utiliza N-FMN será a mesma durante todo periodo de análise. A medida de conservação de energia/insumo proposta é a substituição total ou parcial do $N$-FMN por $N$-adubo verde. Aqui o objetivo é verificar o resultado de uma substituição da fonte de $\mathrm{N}$ mineral pela fonte biológica.

- Cenário Simultâneo f. cenário no qual as duas medidas de conservação de energia/insumo são consideradas simultaneamente, mas sem existir o aumento da proporção da área com milho empregando N-FMN.

Para estudar o efeito de uma maior equidade no consumo de N-FMN, temos:

- Cenário Referencia If. cenário no qual existirá um aumento da proporção da área cultivada com milho que emprega N-FMN ao longo do período de análise, mas onde a eficiência do seu uso está "congelada". A intenção é verificar o efeito de uma maior quantidade de agricultores aplicando FMN, 
sem contudo, estimular conjuntamente a adoção de práticas mais eficientes de manejo do insumo. Este será o cenário base para a comparação com os próximos três cenários.

Verificando o efeito conjunto do uso mais amplo do insumo e da inserção de medidas de economia de N-FMN, temos:

- Cenário Manejo Eficiente If. cenário no qual o aumento da proporção da área com mitho que emprega N-FMN do Cenário Referência Il é mantido, porém haverá uma methora na eficiência do uso de N-FMN. Aqui, a medida de conservação de energia/insumo sugerida é a incorporação do $\mathbf{N}$ FMN em cobertura. Aqui, o objetivo è semelhante ao do Cenário Manejo Eficiente I, mas agora mediante uma maior demanda pelo insumo.

Cenário Adubo Verde II. cenário no qual o aumento da proporção da área com milho que emprega N-FMN é a mesma do Cenário Referência II e Cenário Manejo Eficiente 11 . A medida de conservação de energia/insumo proposta é a substituição total ou parcial do $N$-FMN por $N$-adubo verde. O objetivo é o mesmo do Cenário Adubo Verde II, mas agora com uma área maior empregando FMN.

- Cenário Simultâneo If. cenário no qual o aumento da proporção da área com milho que emprega N-FMN é igual a dos cenários com teminação Il e no qual as duas medidas de conservação de energia/insumo são consideradas simultaneamente. $O$ objetivo aqui é racionalizar a utilização de FMN na cultura do milho.

O ANEXO 5 contém os cenários mostrando todas as etapas dos cálculos efetuados.

\subsubsection{Dados}

Dados estatísticos de produção agricola para construção do ano base, foram obtidos do Anuário Estatístico do Setor de Fertilizantes. Estes incluem área total cultivada com milho (ha), consumo total de FMN para a cultura do milho ( $t$ ), a produção total de milho ( $t)$ e os niveis médios de produtividade (t/ha) de milho para o pais.

Por causa da variação anual na produção agricola, foi considerado como ano base, a média da produção de milho do periodo 1991 a 1995.

A taxa de crescimento da quantidade de Nitrogênio aplicado/ha, calculada através dos dados do Anuário Estatístico Setor de Fertilizantes será empregada para todos os cenários. 
O mercado de sementes de milho, isto é, a proporção de comercialização das sementes com diferentes potenciais produtivos (ZENECA, 1997) ${ }^{8}$, foi utilizada para estimar a área cultivada de milho nos diferentes niveis de produtividade.

Esta divisão é importante porque a cultura do milho apresenta elevada heterogeneidade em termos de produtividade e, também, porque o preço e o potencial produtivo da semente vão determinar a quantidade de insumos necessários para alcançar a produtividade esperada, principalmente fertilizantes.

A necessidade de nitrogênio para produzir 1 tonelada de milho foi considerada como $\underline{15}$ $\mathrm{kg} \mathrm{N} / \mathrm{t}$ milho. Como a bibliografia indica eficiência variável do aproveitamento do N-FMN fornecido, fixou-se o valor de $80 \%$ para eficiência, resultando, portanto, na necessidade de $18 \mathrm{~kg} \mathrm{~N} / \mathrm{t} \mathrm{milho.}$

\subsubsection{Valores Estimados}

Quatro niveis de produtividade de milho foram estimados, de acordo com as informações do mercado de sementes. No ano base, estes niveis são: 750, 1500, 4000 e $7500 \mathrm{~kg} / \mathrm{ha}$. Depois, nos anos de projeção futuros, estes valores servirão apenas de referência para a divisão em niveis de produtividade.

No ano base, a área com milho na qual sementes hibridas (melhoradas) estão sendo usadas foi determinada como empregando N-FMN, enquanto a área equivalente à produção com semente variedade ( $51 \%$ da área cultivada com milho - ZENECA, 1997), foi determinada como não utilizando N-FMN. Dentro disto, a área com milho, por nivel de produtividade, que utiliza N-FMN, foi estimada de modo a resultar no valor total de consumo de N-FMN para a cultura (dados da ANDA).

Para os cenários Manejo Eficiente II, Adubo Verde II e Simultâneo $\|$, nos anos subsequentes, crescentes proporções da área com milho, em cada nivel de produtividade, foram determinadas como empregando N-FMN e/ou substituindo-o por adubo verde, como mostra a tabela 4.10. Isto foi feito com base na meta de proporcionar a uma maior quantidade de produtores a possibilidade de obter uma maior produtividade através do emprego de um insumo importante. Caso a cultura do milho já apresentasse altos índices de emprego de fertilizantes minerais nitrogenados, a meta da distribuição equitativa não precisaria ser incluida no planejamento.

\footnotetext{
${ }^{8}$ comunicação pessoal: Diogênes Panchoni da ZENECA, Cravinhos, SP, via fax, maio de 1997.
} 
Tabela 4.10. Porcentagem estimada da área com milho, por nivel de produtividade, que utiliza FMN durante o período de análise (1995 a 2010) nos Cenários Referência II, Manejo Eficiente II, Adubo Verde II e Simultâneo II.

\begin{tabular}{|r|r|r|r|r|}
\cline { 2 - 5 } \multicolumn{1}{c|}{} & \multicolumn{4}{c|}{ niveis de produtividade (ano base) $\mathrm{kg} / \mathrm{ha}$} \\
\hline ano & 750 & 1500 & 4000 & 7000 \\
\hline 1995 & $0 \%$ & $9 \%$ & $42 \%$ & $50 \%$ \\
\hline 2000 & $5 \%$ & $15 \%$ & $60 \%$ & $70 \%$ \\
\hline 2005 & $15 \%$ & $25 \%$ & $70 \%$ & $80 \%$ \\
\hline 2010 & $25 \%$ & $35 \%$ & $90 \%$ & $95 \%$ \\
\hline
\end{tabular}

Seguindo a estrutura proposta pela metodologia DEFENDUS, a adoção das medidas de economia de N-FMN foi estabelecida da seguinte maneira:

- Nos Cenários Manejo Eficiente II, Adubo Verde II e Simultâneo Il, a cada periodo de cinco anos, a proporção da área que utiliza N-FMN se eleva (tabela 4.11) e esta parcela passará a adotar opções de uso eficiente de N-FMN. Exemplificando:

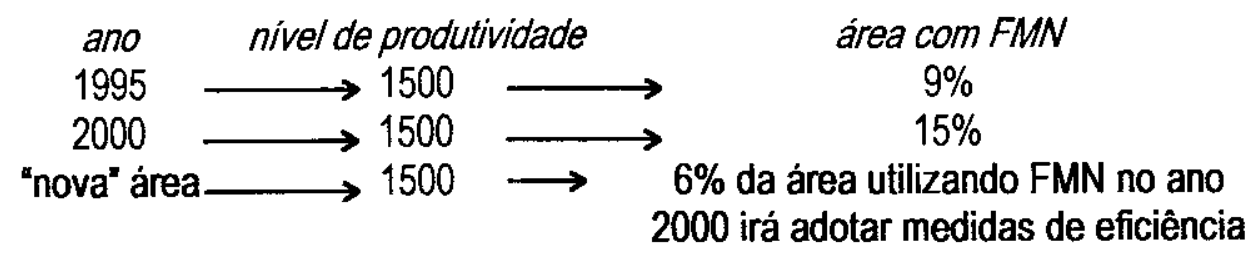

- Em todos os Cenários Contrastados, uma proporção da área com milho que já emprega FMN no ano base (1995) vai, a cada cinco anos, adotar as medidas de eficiência na seguinte proporção:

* ano 2000: $5 \%$ da área.

* ano 2005: $10 \%$ da área.

* ano 2010: $15 \%$ da área.

Para a análise, o requerimento de FMN foi tratado da seguinte maneira: os cálculos foram efetuados com base na demanda pelo nutriente Nitrogênio-FMN. A partir dai, para calcular o requerimento de fertilizantes, amônia e energia, algumas estimativas foram efetuadas.

Através do conteúdo de nitrogênio de cada FMN e da proporção média em que eles foram consumidos no pais, no periodo de 1986 a 1995, obteve-se: 
- concentração média de nitrogênio nos fertilizantes no Brasil.

\begin{tabular}{|l|c|c|c|}
\cline { 2 - 4 } \multicolumn{1}{c|}{} & $\mathrm{a}$ & $\mathrm{b}$ & $\mathrm{a}^{*} \mathrm{~b}$ \\
\cline { 2 - 4 } \multicolumn{1}{c|}{} & $\begin{array}{c}\% \mathrm{~N} / \\
\mathrm{t} \text { fertilizante }\end{array}$ & $\begin{array}{c}\text { proporção de consumo por } \\
\text { tipo de fertilizante }\end{array}$ & $\mathrm{t} \mathrm{N} / \mathrm{t}$ fert \\
\hline uréia & 45,5 & 0,38 & 0,1729 \\
\hline sulfato de amônio & 20,5 & 0,25 & 0,0513 \\
\hline nitrato de amônio & 34,0 & 0,07 & 0,0238 \\
\hline nitrocálcio & 22,0 & 0,05 & 0,0110 \\
\hline MAP & 10,5 & 0,20 & 0,0210 \\
\hline DAP & 18,0 & 0,05 & 0,0090 \\
\hline média & 25,1 & 1,00 & 0,2890 \\
\hline
\end{tabular}

Com este valor, a quantidade de fertilizante em toneladas pode ser calculada.

Exemplificando:

$0,2890 \mathrm{tN} \longrightarrow 1 \mathrm{tFMN}$

$1 \mathrm{tN} \longrightarrow \times \mathrm{tFMN}$

$$
x=3,5548 \text { t FMN }
$$

Para estimar a quantidade de amônia, com base nos fertilizantes consumidos no pais e conhecendo a proporção t amônia/t fertilizante de cada um, é possivel também, calcular a proporção média e, assim, obter o requerimento de amônia.

\begin{tabular}{|l|c|c|c|}
\cline { 2 - 4 } \multicolumn{1}{c|}{} & $a$ & $b$ & $a^{*} b$ \\
\cline { 2 - 4 } \multicolumn{1}{c|}{} & $\mathrm{tNH3/t \text {fert }}$ & $\begin{array}{c}\text { proporção de consumo } \\
\text { por tppo de fertilizante }\end{array}$ & t amônia/t fert \\
\hline uréia & 0,555 & 0,38 & 0,2107 \\
\hline Sulfato de amônio & 0,320 & 0,25 & 0,0800 \\
\hline nittato de amônio & 0,500 & 0,07 & 0,0350 \\
\hline nitrocálcio & 0,470 & 0,05 & 0,0235 \\
\hline MAP & 0,136 & 0,20 & 0,0272 \\
\hline DAP & 0,222 & 0,05 & 0,0111 \\
\hline média & 0,367 & 1,00 & $\mathbf{0 , 3 8 7 5}$ \\
\hline
\end{tabular}

Exemplificando, tem-se: $1 \mathrm{t} F M N=0,3875$ tamônia.

Para calcular o requerimento de energia, emprega-se 0 valor médio para produção de amônia no Brasil (atual = 36,89 GJ/t amônia).

Basear a estimativa de demanda de energia no requerimento de amônia foi a opção escolhida por causa da importância deste produto. A amônia é a matéria-prima base para produção de todos os FMN, e também, representa as maiores proporções do consumo de energia para fabricação dos mesmos. 


\subsubsection{Opcões de Economia e Oferta de FMN}

Opções de economia de FMN nesta análise consistem em medidas que visam reduzir seu requerimento sem diminuir a produção de milho. São elas:

- A possibilidade de substituir o uso de FMN por adubação verde, total ou parcialmente. Como já foi visto, a capacidade de um adubo verde de fomecer nitrogênio é variável, entretanto, para efeito de análise, estipulou-se que a capacidade será de $80 \mathrm{~kg} \mathrm{~N} / \mathrm{ha}$. Isto justifica, então, a substituição total ou parcial do FMN, de acordo com o nivel de produtividade (que reflete na necessidade de nitrogênio).

- A possibilidade de se aplicar o fertilizante de maneira mais eficiente, de modo a reduzir as perdas. A justificativa para tal é o fato de ser a uréia o fertilizante mais usado no Brasil e a maneira de aplicá-lo ao solo mais usual é simplesmente espalhá-lo na superfície. Demonstrou-se através dos estudos mencionados que a incorporacão do fertilizante em cobertura ao solo é capaz de reduzir estas perdas. Para a análise, a capacidade de redução das perdas de nitrogênio será estipulada em:

- 15\% do $\mathrm{N}$ aplicado em cobertura, para os niveis de produtividade equivalentes aos seguintes niveis do ano base $-750,1500$ e $4000 \mathrm{~kg} / \mathrm{ha}$. Considerando, ainda, que os agricultores destas faixas de produtividade aplicam $30 \%$ do nitrogênio necessário na época do plantio e os restantes $70 \%$ na adubação de cobertura.

- $20 \%$ do $\mathrm{N}$ aplicado em cobertura, para o nivel de produtividade equivalente ao seguinte nivel do ano base - $7000 \mathrm{~kg} / \mathrm{ha}$. Considerando, ainda, que os agricultores desta faixa de produtividade aplicam $40 \%$ do nitrogênio necessário na época do plantio e os restantes $60 \%$ na adubação de cobertura.

A racionalização do uso de FMN foi considerada meta principal na construção dos cenários, porque a fixação industrial de nitrogênio representa a principal fonte de ruptura do seu ciclo global. Desta forma, entende-se que a substituição da fonte mineral pela fonte biológica é uma alternativa para reduzir a fixação industrial do nutriente, além de proporcionar melhores condições para seu aproveitamento no sistema de produção agricola. Estabeleceu-se também que, permitindo que a cultura atinja a mesma produtividade, cada fonte será responsável por impactos diferentes ao meio ambiente na esfera de emissões de gases causadores do efeito estufa (dióxido de carbono e óxido nitroso), da quantidade de compostos nitrogenados que contribuirão para a contaminação das águas e dos beneficios adicionais que podem trazer ao agroecossistema. A complexidade de executar tais 
cálculos permitirá que se façam apenas algumas estimativas com o objetivo de criar indices comparativos entre as situações estabelecidas nos cenários.

Já a opção de se introduzir o manejo eficiente do FMN é uma ação relacionada com o objetivo da redução dos distúrbios aos grandes ciclos biogeoquímicos do nitrogênio e do carbono, pois reduz diretamente a demanda pelo insumo, reduzindo simultaneamente os efeitos ambientais negativos provocados pela sua produção e má utilização.

A opção de aumento da oferta de FMN será viabilizada com a possibilidade de importação de nitrogennio na forma de fertilizantes. Este potencial será fixado como sendo a demanda total de FMN no ano 2010 do Cenário Referência II menos a demanda total no Ano Base.

\subsubsection{Cenários de Demanda de Nitrogênio para a Cultura do Milho}

\subsubsection{Resultados}

Os gráficos e as tabelas a seguir mostram os dados obtidos com a construção dos cenários de demanda de N-FMN, e o ANEXO 5 contém os cálculos e a estrutura detalhada.

Gráfico 4.9. Cenários I de demanda de N-FMN.

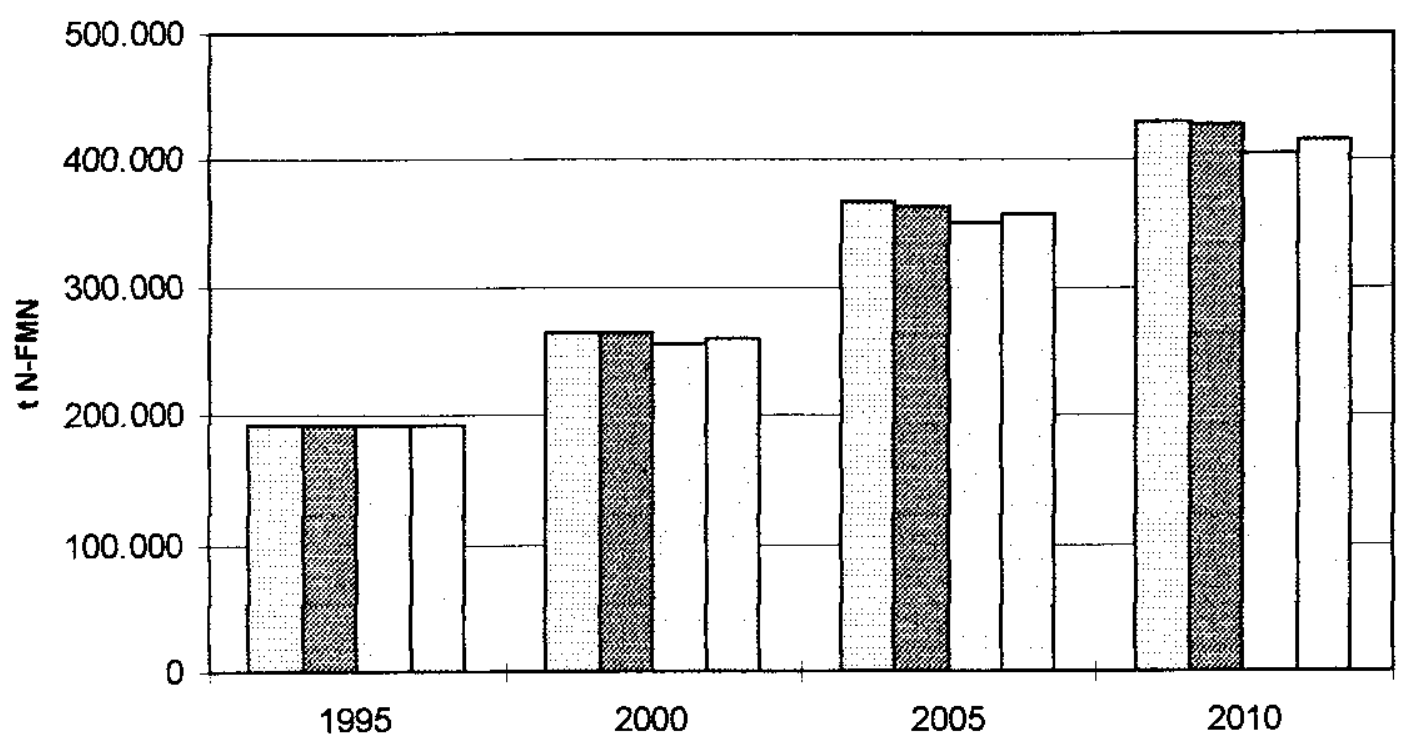

$\square$ Referência I Manejo Eficiente I $\square$ Adubo Verde I $\square$ Simultâneo I 
Gráfico 4.10. Cenários II de demanda de N-FMN.

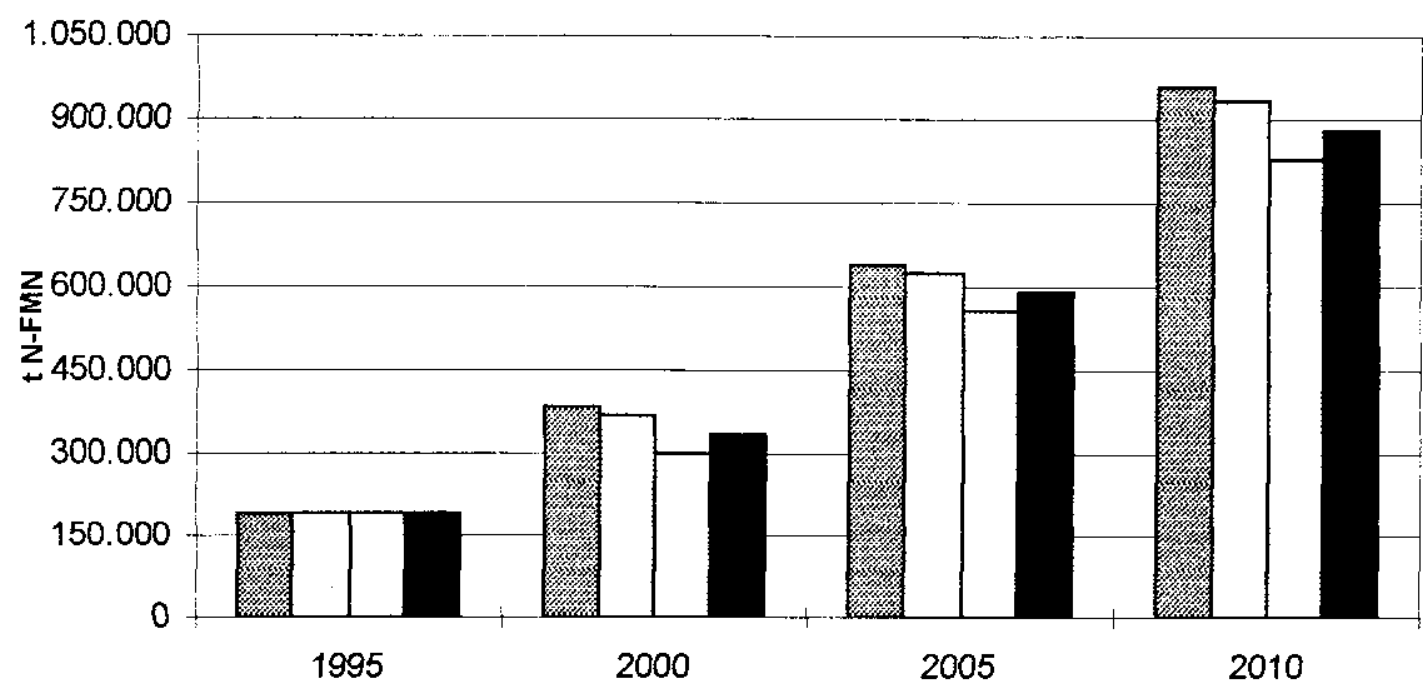

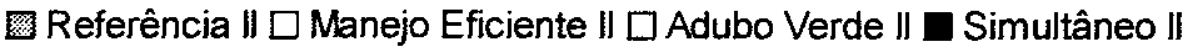

Tabela 4.11. Demanda de fertilizantes minerais nitrogenados resultante da construção dos cenários.

\begin{tabular}{|l|r|r|r|r|}
\hline fertilizante (t) & 1995 & 2000 & 2005 & $\mathbf{2 0 1 0}$ \\
\hline Referência I & 681.349 & 942.708 & 1.304 .327 & 1.529 .058 \\
\hline Referência II & 681.349 & 1.361 .453 & 2.265 .428 & 3.412 .277 \\
\hline Manejo Eficiente II & 681.349 & 1.308 .966 & 2.213 .066 & 3.321 .936 \\
\hline Adubo Verde II & 681.349 & 1.058 .91 & 1.972 .814 & 2.943 .865 \\
\hline Simultâneo II & 681.349 & 1.183 .949 & 2.092 .942 & 3.132 .899 \\
\hline Manejo Eficiente I & 681.349 & 937.439 & 1.294 .303 & 1.517 .612 \\
\hline Adubo Verde I & 681.349 & 913.889 & 1.245 .637 & 1.438 .869 \\
\hline Simultâneo I & 681.349 & 925.659 & 1.269 .970 & 1.478 .242 \\
\hline
\end{tabular}

Tabela 4.12. Demanda de amônia derivada dos cenários de demanda de N-FMN.

\begin{tabular}{|l|r|r|r|r|}
\hline amônia (t) & 1995 & 2000 & 2005 & 2010 \\
\hline Referência I & 264.023 & 365.299 & 505.427 & 592.510 \\
\hline Referência II & 264.023 & 527.563 & 877.853 & 1.322 .257 \\
\hline Manejo Eficiente II & 264.023 & 507.224 & 857.563 & 1.287 .250 \\
\hline Adubo Verde II & 264.023 & 410.328 & 764.466 & 1.140 .748 \\
\hline Simultâneo II & 264.023 & 458.777 & 811.015 & 1.213 .998 \\
\hline Manejo Eficiente I & 264.023 & 363.255 & 501.542 & 588.075 \\
\hline Adubo Verde I & 264.023 & 354.132 & 482.685 & 557.562 \\
\hline Simultâneo I & 264.023 & 358.693 & 492.113 & 572.819 \\
\hline
\end{tabular}


Tabela 4.13. Demanda de energia derivada da demanda de amônia nos cenários construidos.

\begin{tabular}{|l|r|r|r|r|}
\hline amônia (GJ) & 1995 & 2000 & 2005 & 2010 \\
\hline Referência I & 9.739 .792 & 13.475 .894 & 18.645 .195 & 21.857 .695 \\
\hline Referência II & 9.739 .792 & 19.461 .798 & 32.384 .008 & 48.778 .079 \\
\hline Manejo Eficiente II & 9.739 .792 & 18.711 .509 & 31.635 .496 & 47.486 .656 \\
\hline Adubo Verde II & 9.739 .792 & 15.136 .999 & 28.201 .136 & 42.082 .182 \\
\hline Simultâneo II & 9.739 .792 & 16.924 .279 & 29.918 .342 & 44.784 .393 \\
\hline Manejo Eficiente I & 9.739 .792 & 13.400 .484 & 18.501 .895 & 21.694 .069 \\
\hline Adubo Verde I & 9.739 .792 & 13.063 .933 & 17.806 .232 & 20.568 .457 \\
\hline Simultâneo I & 9.739 .792 & 13.232 .183 & 18.154 .063 & 21.131 .288 \\
\hline
\end{tabular}

\subsubsection{Comentários}

No ano base (1995), a área produzindo milho que utiliza FMN foi calculada como sendo $16 \%$. A elevação desta porcentagem, no ano 2010 , para $47,4 \%$ provocará um aumento na demanda de N-FMN da ordem de $123 \%$ (de acordo com os resultados do cenário Referência II), correspondendo a uma taxa de crescimento de 11,34\%a.a.. Esta demanda corresponde a 1.322.257 t de amônia - mais do que a produção atual total de amônia no pais (1.257.600 t) - só para a cultura do milho.

Com relação à produção, dos $31.279 .316 \mathrm{t}$ milho atuais, no ano 2010 , caso a proporção da área empregando FMN não se altere, a estimativa dos cenários permite atingir $45.475 .770 \mathrm{t}$ milho. Caso ocorra um aumento da área empregando FMN, esta produção pode atingir $63.121 .831 \mathrm{t}$ milho $38,8 \%$ a mais. A diferença entre as taxas de crescimento da produção em 2010 chega a 2,26 pontos percentuais (tabela 4.14).

Tabela 4.14. Taxas de crescimento da produção e produtividade do milho em todos os cenários, no período de 1995 a 2010.

\begin{tabular}{|c|c|}
\hline cenários & taxa de crescimento \\
\hline produção (t) & \\
\hline R.I, ME.I, AV.I, S.I & $2,53 \%$ \\
\hline R.II, ME.II, AV.II e S.II & $4,79 \%$ \\
\hline produtuvidade (kg/ha) \\
\hline R.I, ME.I, AV.I, S.I & \\
\hline R.II, ME.II, AV.II e S.II & $2,22 \%$ \\
\hline
\end{tabular}


A produtividade também seria afetada, crescendo a uma taxa de 2,22\%a.a, enquanto 0 aumento da área usando insumos provocaria um crescimento de $4,48 \%$ a.a. na produtividade (tabela 4.14). Teria-se, em 2010 , uma produtividade de $3140 \mathrm{~kg}$ milho/ha contra $4359 \mathrm{~kg}$ milho/ha para os cenários onde a área com N-FMN se elevaria.

Com os dados de demanda de N-FMN e produção de milho em 2010 , chega-se a uma proporção de $9,45 \mathrm{kgN} / \mathrm{t}$ milho sendo fomecido na forma de FMN para o Cenário Referência I. Para o Cenário Referência II, este valor chega a $15,2 \mathrm{~kg} \mathrm{~N} / \mathrm{t}$ milho. Estes indices permitem dizer que existirá uma constante extração de nutrientes do solo sem sua devida reposição, na situação proposta pelo Cenário Referência I. A hipótese do Cenário Referência II indica uma melhora significativa do equilibrio extração de nutriente / reposição com FMN, alcançando quase o ideal de $18 \mathrm{~kg} \mathrm{~N} / \mathrm{t}$ milho quando se considera uma eficiência de $80 \%$ de aproveitamento do FMN.

Observações mais especificas serão feitas em dois blocos, para separar os cenários em que há mudança, ao longo do periodo de análise, da área aplicando FMN daqueles onde ela não varia.

\subsubsection{2.a. Cenários sem crescimento da proporcão da área com milho} utilizando FMN

(Cenário Referência I Cenário Manejo Eficiente I Cenário Adubo Verde 1)

Cenário Simultâneo Tendencial)

Não aumentar a proporção da área com milho que emprega $\mathrm{N}$-FMN resulta em uma demanda de 430.139 t N-FMN em 2010. Este valor está 100\% abaixo da demanda no Cenário Adubação Verde II, que já introduz uma medida de economia de N-FMN. Quando comparado ao Cenário Referência II, a demanda no Cenário Referência I é 123\% menor, no ano 2010. A economia em gás natural seria de cerca de 500.000 t em relação aos Cenários Referência II e Adubação Verde II.

Os índices de economia de N-FMN alcançados pelos cenários eficientes são: 0,75\% para Cenário Manejo Eficiente 1, 5,90\% para Cenário Adubo Verde I e 3,32\% para Cenário Simultâneo I. Isto equivale a 15\% da área cultivada com milho que utiliza N-FMN em 2010 (321.979 ha) adotando as alternativas de uso eficiente do N-FMN propostas nos três diferentes cenários. 


\subsubsection{2.b. Cenários com crescimento da proporcão da área com milho}

\section{utilizando FMN}

(Cenário Referência ll Cenário Manejo Eficiente II Cenário Adubo Verde II Cenário Simultâneo II)

O Cenário Manejo Eficiente II, que supõe a incorporação do adubo aplicado em cobertura, demonstrou uma economia de $3 \%$ de N-FMN $(25.414$ † N), em 2010, em relação ao Cenário Referência II. Em termos de amônia, a produção evitada é equivalente a 35.007 t ou 25.828 t de gás natural. Com relação ao ritmo de crescimento da demanda, a redução da taxa de crescimento seria de apenas 0,20\%a.a., passando a ser, portanto, de 11,14\%a.a.. entre 1995 e 2010.

A substituição por adubação verde (Cenário Adubação Verde II) gera uma redução de $13,7 \%$ no requerimento de N-FMN. Por sua vez, equivale a mais de cinco meses de produção de amônia em unidade de 1000 t amônia/dia. Em termos de energia equivalente, 133.917 t de gás natural estariam sendo poupadas.

O efeito na taxa de crescimento da demanda de N-FMN seria de 10,25\%a.a., apontando uma redução de 1,09\%a.a. pontos porcentuais.

Estas reduções, de acordo com a estrutura dos cenários Manejo Eficiente Il, Adubo Verde II e Simultâneo II, refletem a adoção das medidas de economia de N-FMN em $63 \%$ da área que estaria utilizando N-FMN no Cenário Referência II. Será necessário, então, que as altemativas propostas sejam adotadas em aproximadamente 4.000 .000 ha.

Para verificar o efeito simultâneo das duas opções de economia de N-FMN, o Cenário Simultâneo II sugere que cada uma será adotada em metade da área total definida como alvo das mudanças. O resultado aponta uma diminuição de $8,1 \%$ (78.592 t N-FMN a menos) no requerimento de N-FMN ou 108.259 t amônia.

\subsubsection{C. Emissōes de $\mathrm{CO}_{2}, \mathrm{~N}_{2} \mathrm{O}$ e NO}

A redução no consumo de N-FMN observada nos cenários considerados eficientes também provoca uma redução das emissões de $\mathrm{CO}_{2}$ e NO $\mathrm{N}_{x}$ caso se considere que este montante deixará de ser fabricado. Considerando a quantidade de amônia que não será sintetizada e estipulando a emissão de dióxido de carbono em 1,15 t $\mathrm{CO}_{2} / \mathrm{t} \mathrm{NH}_{3}$ e a de $\mathrm{NO}_{\mathrm{x}}$ em $0,0015 \mathrm{t} \mathrm{NO}_{\mathrm{x}} / \mathrm{t} \mathrm{NH_{3 }}$,pode-se indicar a quantidade destes gases que não será liberada na atmosfera. 
O Cenário Adubação Verde II permitirá uma redução na emissão de 208.736 t de $\mathrm{CO}_{2}$ e de 272 t de $\mathrm{NO}_{\mathrm{x}}$ em 2010.

O Cenário Manejo Eficiente II, em 2010, resultará em 40.259 t de $\mathrm{CO}_{2}$ e 52 t de $\mathrm{NO}_{x}$ a menos.

A adoção de uma política de racionalização do uso de $\mathrm{N}$ englobando as duas medidas propostas deixará de emitir em 2010, $124.498 \mathrm{t} \mathrm{CO}_{2}$ e 162 t de $\mathrm{NO}_{x}$ (Cenário Simultâneo II).

Os cenários onde não se considerou a elevação da proporção da área com milho empregando FMN também propiciam em 2010, uma redução nas emissões, porém, em menor escala por causa da menor quantidade demandada do nutriente:

- Cenário Manejo Eficiente l: redução de 5.101 t CO 2 e 6,6 t $\mathrm{NO}_{x}$.

- Cenário Adubação Verde I: redução de 40.190 t $\mathrm{CO}_{2}$ e 52 t NO .

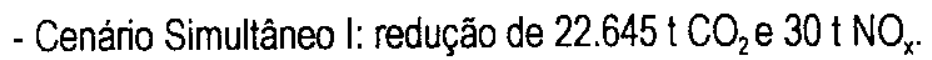

Os cenários que propõem uma redução da quantidade de N-FMN através da incorporação do fertilizante aplicado em cobertura estariam efetivamente reduzindo os impactos negativos no ciclo do nitrogênio porque evitam o consumo de FMN. Quanto menor o consumo de FMN, menor a necessidade de sua produção e menores os efeitos ambientais negativos do processo industrial de produção.

Já os cenários onde se sugere a substituição do FMN por adubo verde, a quantidade total do nutriente não se altera, porém, sabe-se que a adoção desta prática pode, no longo prazo, tomar o sistema agricola mais eficiente porque:

- a cobertura morta proveniente do material vegetal da adubação verde evita perdas de solo e nutrientes por erosão

- o fato do nitrogênio a ser fornecido pelo adubo verde depender de sua decomposição faz com que este seja disponibilizado mais lentamente se comparado à aplicação de FMN. Esta liberação lenta pode evitar perdas por lixiviação e volatilização porque a cultura comercial será capaz de absorvê-lo. Portanto, de uma maneira geral, a inserção desta fonte biológica contribui para a diminuição dos distúrbios provocados pela atividade agrícola ao ciclo giobal do nitrogênio.

As emissões de $\mathrm{N}_{2} \mathrm{O}$, sendo provenientes da desnitrificação, podem ser reduzidas com a introdução destas medidas quando considera-se que os compostos nitrogenados ao invés de sofrerem desnitrificação, estarão sendo absorvidos mais eficientemente pelas culturas. 


\subsubsection{Custos: Metodologia de Cálculo e Resultados}

\subsubsection{Metodologia}

Para comparar as opções de produção e economia de nitrogênio, a figura de mérito Custo do Nitrogênio Economizado foi utilizada. Para os cálculos, somente os custos adicionais referentes à adoção das medidas de conservação de nitrogênio/energia foram contabilizados. O ANEXO 6 detalha os cálculos.

$$
C N E=\frac{C C V A}{\text { nitrogênia-FMN economizado }} \quad \text { (equação I) }
$$

CNE = custo do nitrogénio-FMN economizado (US\$ $/ \mathrm{kg} N)$

$$
C C V A=I_{o}^{*} F R C+O \& M-C E C F-C E G \quad \text { (equação H) }
$$

onde:

CCVA - custo do ciclo de vida anualizado (US\$)

$I_{0}$ - investimento inicial (US\$)

O\&M - custos anuais de operação e manutenção (US\$)

CECF - custos evitados de compra de fertilizante

CEG - custos evitados gerais

$$
F R C=\frac{i}{\left[1-(1+i)^{-N}\right]} \text { ou } \quad F R C=\frac{i(1+i)^{N}}{(1+i)^{N}-1} \text { (equação III) }
$$

onde:

FRC - fator de recuperação de capital

i - taxa de desconto (10\% ao ano)

$N$ - vida útil do equipamento - 10 anos

O custo por hectare dos implementos e operações agricolas foi obtido do Anuário Estatístico AGRIANUAL 1998.

Do Anuário Estatístico do Setor de Fertilizantes obteve-se o preço da uréia.

A empresa PIRAI SEMENTES ${ }^{9}$ forneceu os preços das sementes para adubação verde.

\footnotetext{
${ }^{9}$ comunicação pessoal: Engenheiro Agrônomo Jorge Potascheff Junior da empresa Pirai Sementes, Piracicaba,SP, setembro de 1998.
} 
Pode-se afirmar que tanto a técnica de adubação verde como a incorporação do FMN criam externalidades positivas ${ }^{10}$ no sistema de produção de milho, sob a ótica da economia ecológica. Estas externalidades positivas podem ser incluidas no cálculo do CNE na forma do custo evitado.

Decidiu-se incluir os custos evitados de compra de fertilizante mineral nitrogenado, resultante da economia de nitrogênio através das medidas propostas. Os vários benefícios causados pela adoção da adubação verde, enumerados no item 4.3, podem ser incluídos no cálculo como custo evitado geral.

\subsubsection{Resultados}

\subsubsection{2.a. Opcōes de Oferta de N-FMN}

O preço de importação da uréia, em US\$/kg $N$ foi determinado como sendo US $\$ 0,42 \mathrm{~kg} \mathrm{~N}$ pela média dos preços mensais, de 1993 a 1996, registradas no Anuário Estatistico do Setor de Fertilizantes como preços vigentes para vendas industriais.

\subsubsection{2.b. Incorporação ao Solo do FMN Aplicado em Cobertura}

Com relação a incorporar o FMN aplicado em cobertura, o Custo do Nitrogênio Economizado varia de acordo com a quantidade de N-FMN aplicada por hectare (gráficos $4.9 \mathrm{e}$ 4.10), porém, esta variação é mínima. Em uma amplitude de aplicação de 50 a $200 \mathrm{~kg} \mathrm{~N}$-FMN/ha, a diferença no CNE è de apenas US $\$ 0,03$.

Pode-se dizer que esta variação não è significativa, o que não impede 0 agricultor que aplica menores doses de N-FMN de adotar esta medida.

Observa-se que, ao incluir os custos evitados da compra de FMN ao cálculo do CNE, este toma-se negativo (gráfico 4.10), o que significa que há ganhos ao invés de gastos com a adoção da incorporação do FMN ao solo.

\footnotetext{
${ }^{10}$ Uma externalidade ocorre quando um processo produtivo afeta outro processo de produçāo, ou seja, quando uma atitude realizada em determinado lugar gera impactos negativos ou positivos, que não eram os objetivos da ação, neste lugar ou em qualquer outro (HERCOWITZ, 1997).
} 
Gráfico 4.9. CNE de incorporar o FMN em cobertura sem incluir os custos evitados.

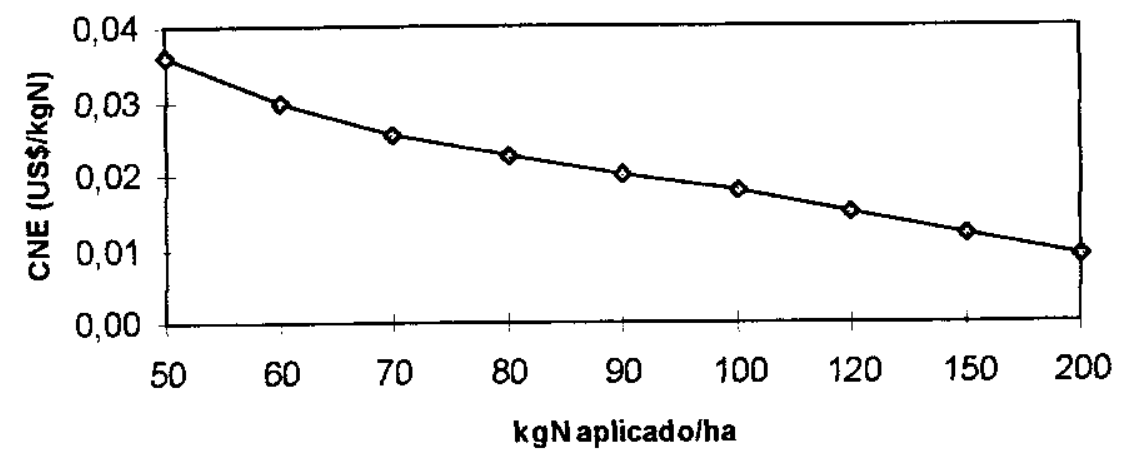

Gráfico 4.10. CNE de incorporar o FMN em cobertura incluindo os custos evitados.

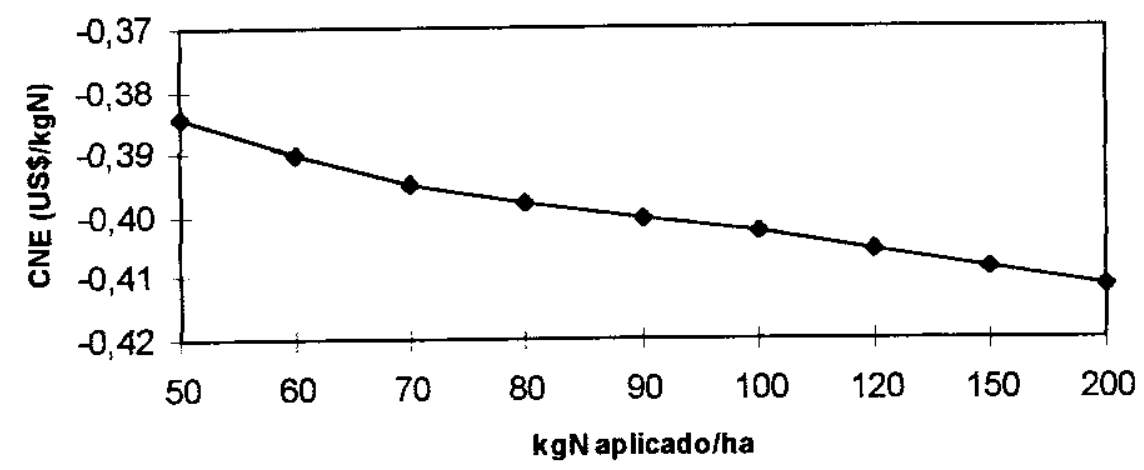

\subsubsection{2.c. Adubação Verde}

Existe uma grande variação entre os preços das sementes para adubação verde porque 0 potencial de fornecimento de nitrogênio por quilograma de semente é diferente entre as epécies. A recomendação da quantidade de sementes a ser semeada por hectare, depende, portanto:

- da espécie de adubo verde escolhida.

- da produtividade esperada da cultura comercial.

Por isso, o Custo do Nitrogênio Economizado com o emprego deste insumo também irá oscilar, por isso decidiu-se efetuar os cálculos do CNE utilizando quatro espécies de leguminosas empregadas como adubo verde: crotalária, mucuna, feijão-de-porco e guandu.

Para demonstrar 0 efeito da necessidade de nitrogênio a ser fomecido pelo adubo verde, calculou-se o CNE considerando duas quantidades de sementes da mesma espécie por hectare. Os 
dados da quantidade de nitrogênio fornecido por espécie de adubo verde foram compilados de COSTA et al. (1993).

Como existe a possibilidade de se produzir a semente do adubo verde na propriedade agrícola, optou-se por calcular o custo do nitrogênio economizado através de duas alternativas: considerando a compra anual de sementes e considerando a compra de sementes de adubo verde a cada cinco anos, o que significa que, neste período, o produtor estará produzindo sua própria semente. Considerou-se que não haverá gastos com insumos extemos neste periodo para a aquisição das sementes.

Os resultados estão divididos nas tabelas a seguir.

Tabela 4.15. CNE com substituição por adubação verde, sem considerar os custos evitados.

\begin{tabular}{|c|c|c|c|c|}
\hline espécie & comprando & $\begin{array}{l}\text { nte anualmente } \\
\mathrm{kgN})\end{array}$ & $\begin{array}{r}\text { comprando } \\
\text { anc }\end{array}$ & $\begin{array}{l}\text { ente de } 5 \text { em } 5 \\
\$ \$ / \mathrm{kgN})\end{array}$ \\
\hline N fomecido & $140 \mathrm{kgN} / \mathrm{ha}$ & $70 \mathrm{kgN} / \mathrm{ha}$ & $140 \mathrm{kgN} / \mathrm{ha}$ & $70 \mathrm{kgN} / \mathrm{ha}$ \\
\hline crotalária & 1,55 & 1,61 & 0,26 & 0,33 \\
\hline N fomecido & $150 \mathrm{kgN} / \mathrm{ha}$ & $75 \mathrm{kgN} / \mathrm{ha}$ & $150 \mathrm{kgN} / \mathrm{ha}$ & $75 \mathrm{kgN} / \mathrm{ha}$ \\
\hline mucuna & 1,25 & 1,31 & 0,22 & 0,28 \\
\hline N fornecido & $120 \mathrm{kgN} / \mathrm{ha}$ & $60 \mathrm{kgN} / \mathrm{ha}$ & $120 \mathrm{kgN} / \mathrm{ha}$ & $60 \mathrm{kgN} / \mathrm{ha}$ \\
\hline feiläo-de-porco & 2,41 & 2,48 & 0,38 & 0,46 \\
\hline N fornecido & $90 \mathrm{kgN} / \mathrm{ha}$ & $45 \mathrm{kgN} / \mathrm{ha}$ & $90 \mathrm{kgN} / \mathrm{ha}$ & $45 \mathrm{kgN} / \mathrm{ha}$ \\
\hline guandu & 1,39 & 1,49 & 0,27 & 0,38 \\
\hline
\end{tabular}

Tabela 4.16. CNE com substituição por adubação verde, considerando os custos evitados.

\begin{tabular}{|c|c|c|c|c|}
\hline \multirow{2}{*}{$\frac{\text { espécie }}{\text { Nfornecido }}$} & \multicolumn{2}{|c|}{$\begin{array}{c}\text { comprando semente anualmente } \\
\text { (US\$/kgN) }\end{array}$} & \multicolumn{2}{|c|}{$\begin{array}{c}\text { comprando semente de } 5 \text { em } 5 \\
\text { anos (US\$/kgN) }\end{array}$} \\
\hline & $140 \mathrm{kgN} / \mathrm{ha}$ & $70 \mathrm{kgN} / \mathrm{ha}$ & $140 \mathrm{kgN} / \mathrm{ha}$ & $70 \mathrm{kgN} / \mathrm{ha}$ \\
\hline crotalária & 1,13 & 1,19 & $-0,16$ & $-0,09$ \\
\hline N fornecido & $150 \mathrm{kgN} / \mathrm{ha}$ & $75 \mathrm{kgN} / \mathrm{ha}$ & $150 \mathrm{kgN} / \mathrm{ha}$ & $75 \mathrm{kgN} / \mathrm{ha}$ \\
\hline mucuna & 0,83 & 0,89 & $-0,20$ & $-0,14$ \\
\hline N fornecido & $120 \mathrm{kgN} / \mathrm{ha}$ & $60 \mathrm{kgN} / \mathrm{ha}$ & $120 \mathrm{kgN} / \mathrm{ha}$ & $60 \mathrm{kgN} / \mathrm{ha}$ \\
\hline feijäo-de-porco & 1,99 & 2,06 & $-0,04$ & 0,04 \\
\hline N formecido & $90 \mathrm{kgN} / \mathrm{ha}$ & $45 \mathrm{kgN} / \mathrm{ha}$ & $90 \mathrm{kgN} / \mathrm{ha}$ & $45 \mathrm{kgN} / \mathrm{ha}$ \\
\hline guandu & 0,97 & 1,07 & $-0,15$ & $-0,04$ \\
\hline
\end{tabular}


Portanto, optar pela adubação verde como fonte de nitrogênio, comprando as sementes anualmente não é viável quando comparam-se os custos com o preço do kg de nitrogênio da uréia: US $\$ 0,42$.

Mesmo que se considere o FMN que o agricultor deixaria de comprar, o nitrogênio fornecido pela adubação verde, adquirindo as sementes anualmente no comércio, ainda fica mais caro do que o custo do nitrogênio da uréia.

Comprar a semente de cinco em cinco anos é uma alternativa que viabiliza financeiramente a adoção da técnica. Todas as espécies avaliadas indicaram um custo menor do que o preço do $\mathrm{kg}$ de $\mathrm{N}$ da uréia.

Internalizar a vantagem em termos de economia de energia e combustivel fóssil quando 0 custo de FMN que deixaria de ser comprado é inserido no cálculo, resulta em custos negativos (comprando sementes de 5 em 5 anos).

Afirma-se que não se pode deixar de levar em conta no custo, os beneficios provocados pela adubação verde além do fornecimento de nitrogênio. Para mostrar o efeito, foi feito um exercicio considerando a diminuição do uso de herbicidas ao longo do período de análise de 10 anos para o adubo verde crotalária (tabela 4.17 e gráficos 4.13 e 4.14).

Tabela 4.17. Necessidade de uso de herbicida e custo/ha ao empregar adubação verde por 10 anos.

\begin{tabular}{|l|c|c|c|c|c|c|c|c|c|c|}
\hline \multicolumn{1}{|c|}{ ANO } & $\mathbf{1}$ & $\mathbf{2}$ & $\mathbf{3}$ & $\mathbf{4}$ & $\mathbf{5}$ & $\mathbf{6}$ & $\mathbf{7}$ & $\mathbf{8}$ & $\mathbf{9}$ & $\mathbf{1 0}$ \\
\hline litros de herbicida/ ha & $\mathbf{5}$ & $\mathbf{5}$ & $\mathbf{5}$ & $\mathbf{5}$ & $\mathbf{4}$ & $\mathbf{4}$ & $\mathbf{3}$ & 2 & 0 & $\mathbf{0}$ \\
\hline US\$n (AGRIANUAL 98) & 10,32 & 10,32 & 10,32 & 10,32 & 10,32 & 10,32 & 10,32 & 10,32 & 10,32 & 10,32 \\
\hline custo total/ha & 51,6 & 51,6 & 51,6 & 51,6 & 41,28 & 41,28 & 30,96 & 20,64 & 0 & 0 \\
\hline custo evitado/ha & $\mathbf{0}$ & $\mathbf{0}$ & $\mathbf{0}$ & $\mathbf{0}$ & $\mathbf{1 0 , 3 2}$ & $\mathbf{1 0 , 3 2}$ & $\mathbf{2 0 , 6 4}$ & $\mathbf{3 0 , 9 6}$ & $\mathbf{5 1 , 6}$ & $\mathbf{5 1 , 6}$ \\
\hline
\end{tabular}


Gráfico 4.13. CNE para crotalária incluindo custos evitados com economia de herbicida, comprando sementes anualmente e considerando ou não os custos evitados com a compra de FMN.

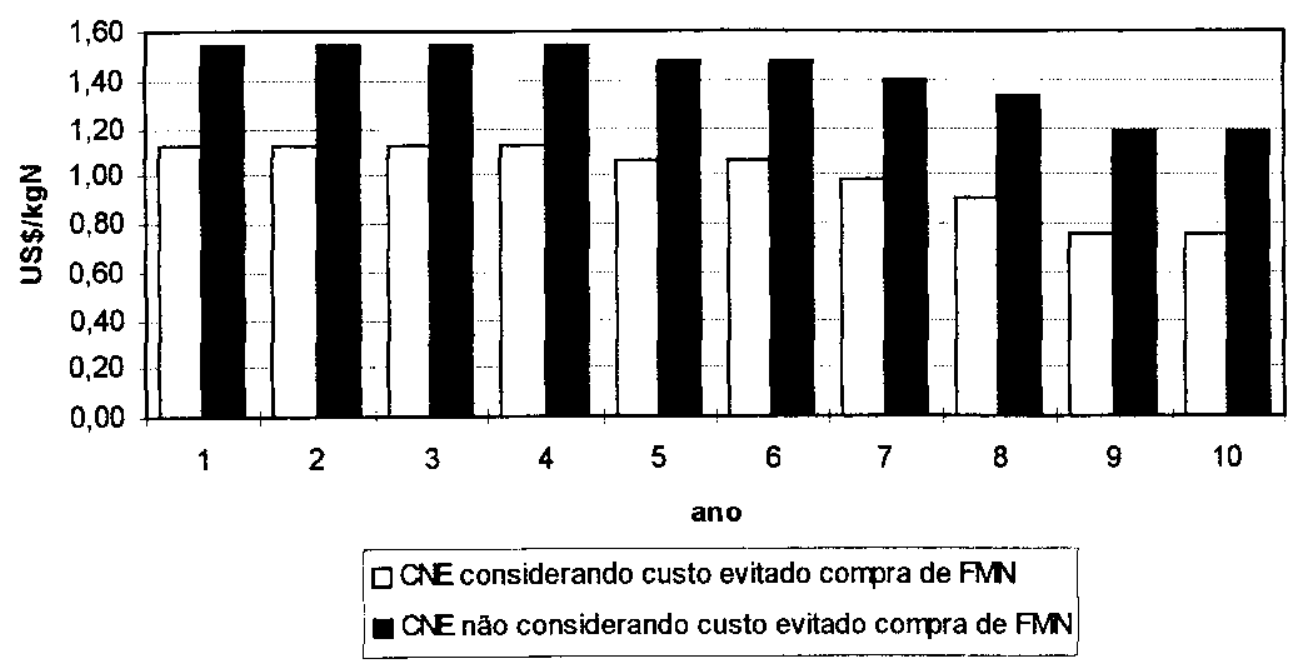

Gráfico 4.14. CNE para crotalária incluindo custos evitados com economia de herbicida, comprando sementes de 5 em 5 anos e considerando ou não os custos evitados com a compra de FMN.

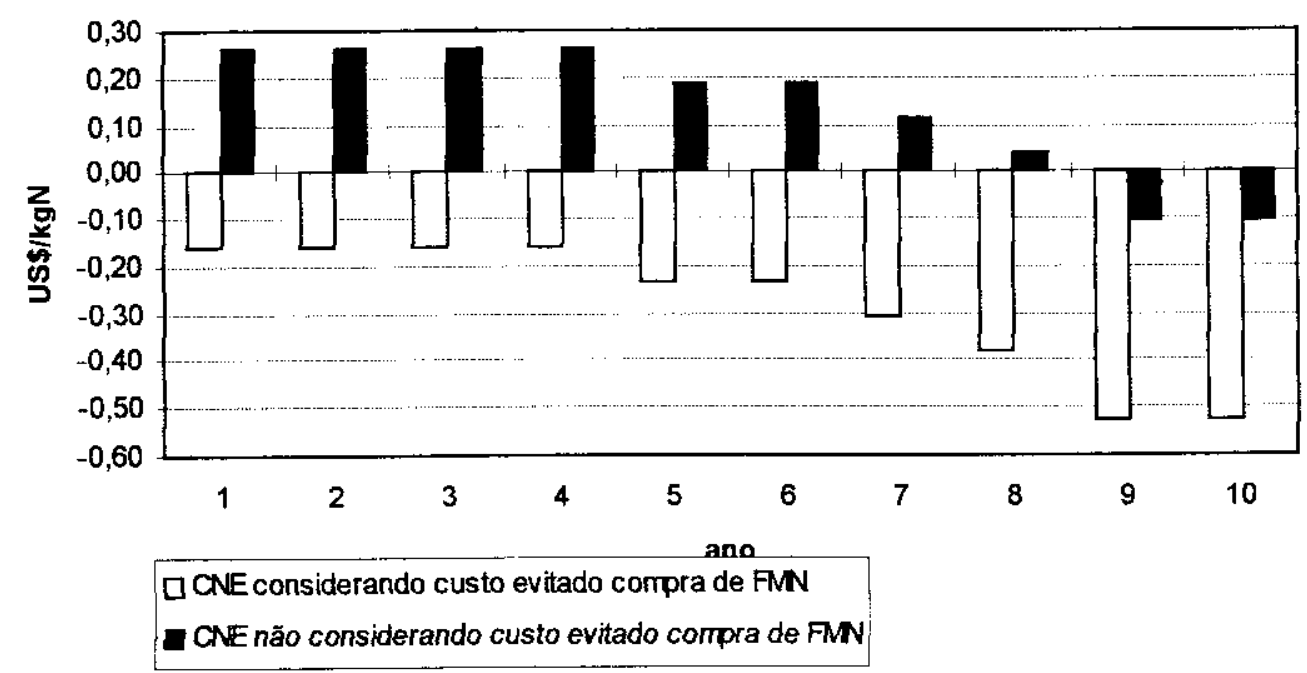

Financeiramente, mesmo que se considere o custo evitado com a compra de herbicida, comprar a semente do adubo verde anualmente, com os preços atuais deste insumo no mercado, não é atraente para o agricultor se comparado ao preço do FMN.

Comprovando as afirmações anteriores, produzir a semente na própria propriedade e considerar todos os custos que seriam evitados caso esta fonte renovável de nitrogênio fosse usada, reflete em ganhos de faturamento para o produtor. Custos negativos são uma forma de indicar a melhora do rendimento financeiro. 


\subsubsection{Curvas cumulativas de recursos para opcōes de oferta elou economia de N-FMN}

As curvas cumulativas de recursos indicam o minimo custo de um mix de alternativas de fomecimento ou economia de N-FMN capazes de suprir a demanda por este insumo calculada nos cenários (REDDY et al. 1995). Elas foram construídas considerando-se que a demanda de N-FMN no ano 2010 será a maior demanda de nitrogênio obtida nos cenários, no caso o Cenário Referência II. Em seguida, as opções de fornecimento/economia de N-FMN foram organizadas em ordem crescente dos custos por $\mathrm{kg} \mathrm{N}$ e o potencial de fornecimento/economia de $\mathrm{N}$-FMN em toneladas de cada altemativa foi computado. Este procedimento é representado na forma de uma escada, onde a quantidade de N-FMN é representada no eixo horizontal e o custo por $\mathrm{kg} \mathrm{N}$ no eixo vertical. Então, o comprimento de cada degrau indica o potencial de fomecimento/economia de N-FMN de determinada alternativa e a altura è referente ao seu custo por $\mathrm{kg} \mathrm{N}$, o que significa que o retângulo formado por cada degrau da escada corresponde ao custo total da adoção daquela determinada opção. Finalmente tem-se que uma opção será escolhida somente se seu custo e seu potencial de fornecimento/economia de N-FMN encontrem um lugar na curva antes da meta de demanda estipulada (no caso, Cenário Referência II) (REDDY et al. 1995).

Gráfico 4.15. Curva cumulativa de recursos considerando o custo da semente de AV sendo comprada anualmente e não considerando os custos evitados.

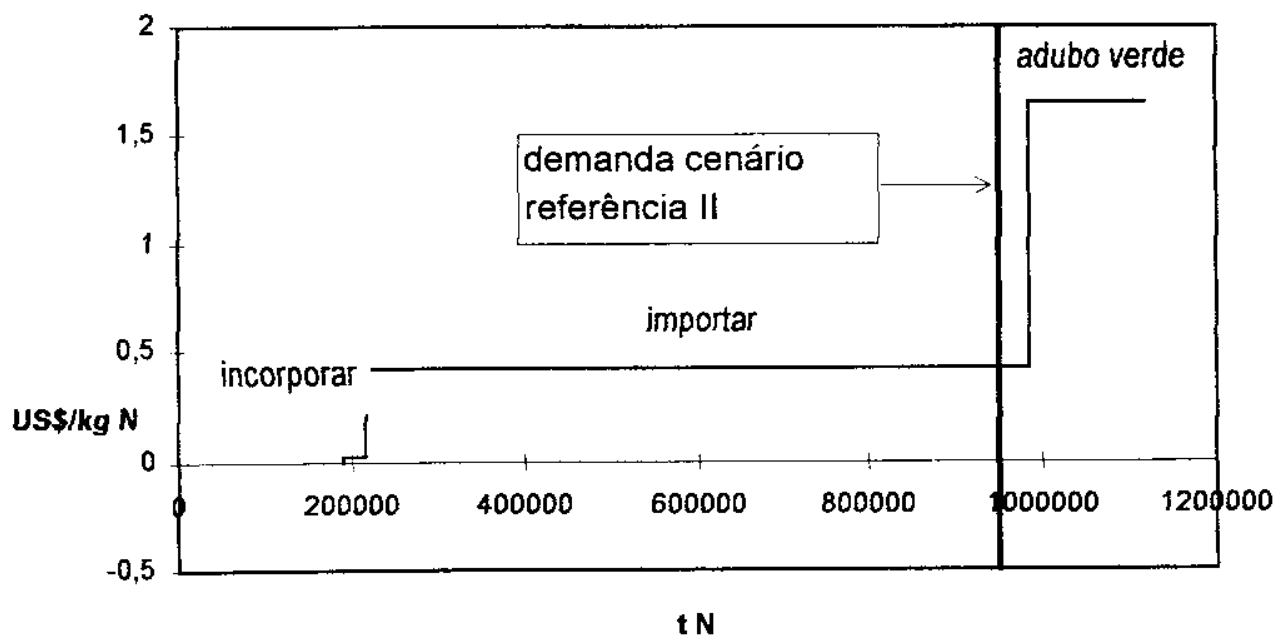


Gráfico 4.16. Curva cumulativa de recursos considerando o custo da semente de AV sendo comprada anualmente e os custos evitados.

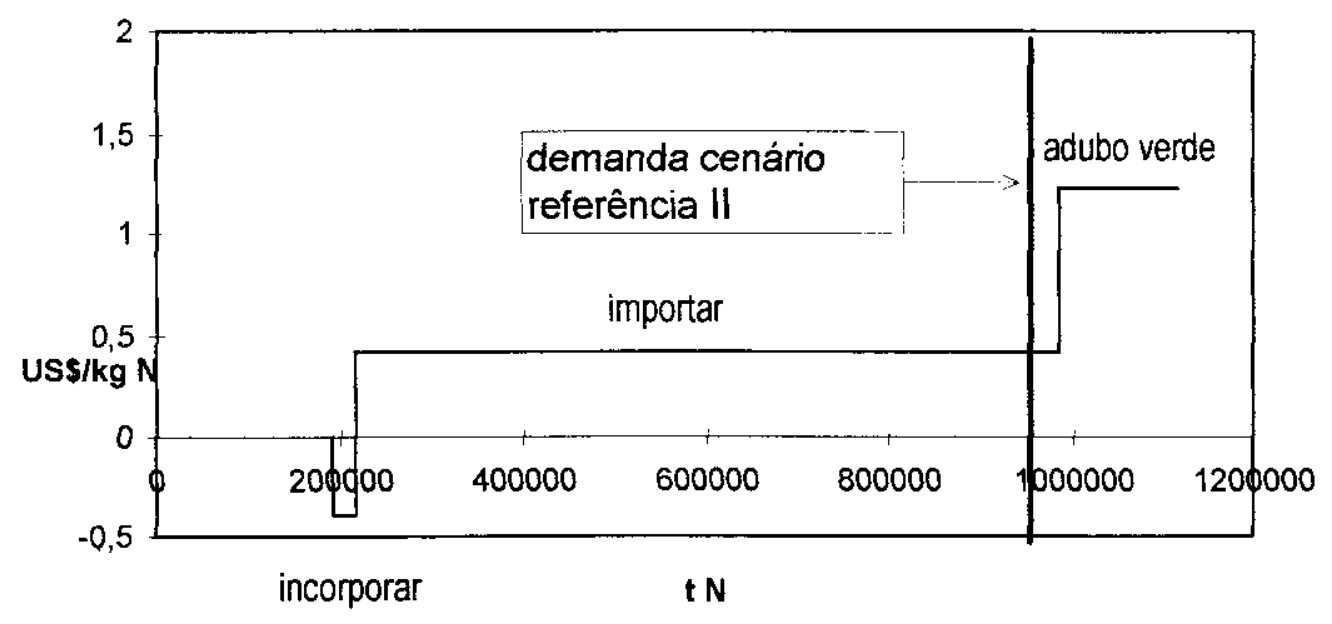

Gráfico 4.17. Curva cumulativa de recursos considerando o custo da semente de AV sendo comprada a cada cinco anos e não considerando os custos evitados.

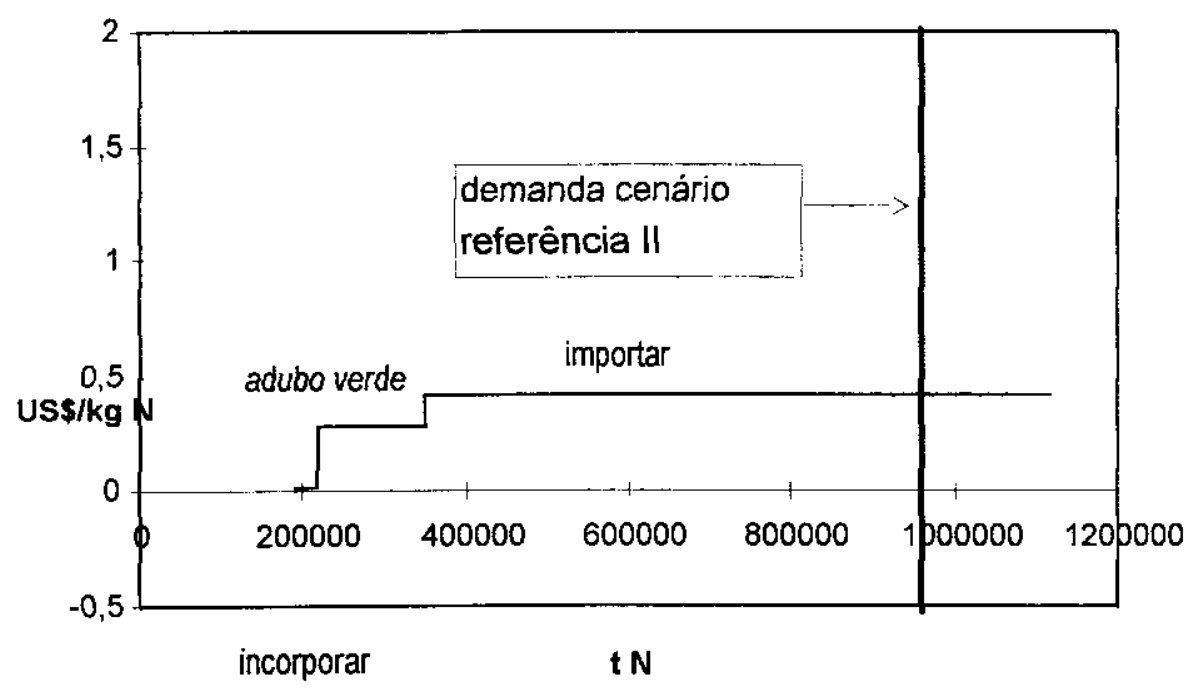


Gráfico 4.18. Curva cumulativa de recursos considerando o custo da semente de AV sendo comprada a cada cinco anos e os custos evitados.

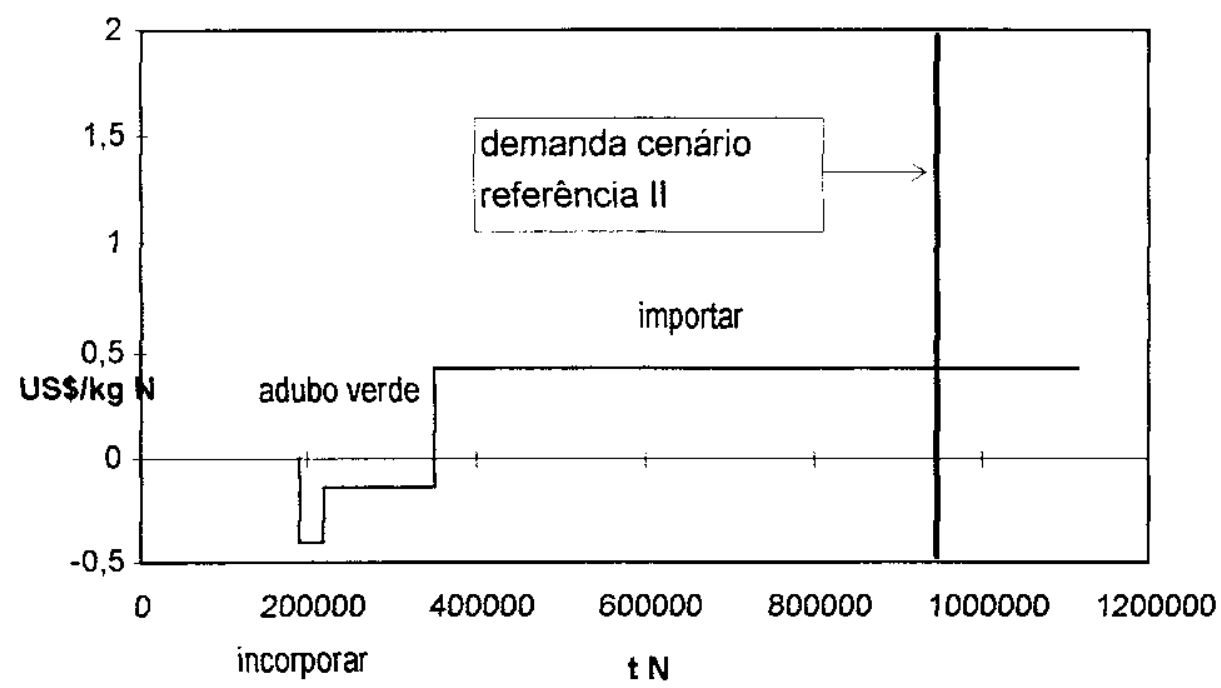

Observando estas quatro curvas, nota-se que o potencial de economia de N-FMN através da incorporação deste ao solo é pequeno, equivalente a 25.413 t $\mathrm{N}$ de uma demanda total de $959.907 \mathrm{t} N$, porém, seu custo é muito reduzido, chegando a ser negativo quando se consideram os custos evitados com a compra do FMN.

Com relação à adubação verde, não existe possibilidade de adoção desta prática quando o agricultor compra as sementes anualmente, mesmo considerando os custos evitados com a compra do FMN (gráficos 4.15 e 4.16), pois seu custo por $\mathrm{kg} \mathrm{N}$ é maior que 0 custo por $\mathrm{kg} \mathrm{N}$ da uréia importada.

Caso o agricultor produza as sementes na propriedade, comprando-as no mercado somente a cada cinco anos para garantir seu potencial biológico, a prática da adubação verde pode evitar o consumo de 131.769 t N-FMN pois seu custo por kg N-FMN economizado é menor do que o custo por $\mathrm{kg} \mathrm{N}$ da uréia importada (gráficos 4.17 e 4.18). 


\section{CONCLUSÕES}

\subsection{Conclusões}

A presente dissertação permitiu formular conclusões sob diferentes aspectos: a indústria de amônia, a demanda de nitrogênio para cultura do milho e questões relacionadas aos ciclos do carbono e do nitrogênio. Para facilitar a compreensão, optou-se por indicá-las separadamente.

Indústria de amônia

A indústria de amônia no Brasil possui um parque industrial antigo onde não se realizam investimentos em modernização há dez anos. Em consequência disto, apresenta um consumo de energia na forma de materia-prima e combustivel, $32 \%$ acima do valor alcançado nas unidades mais modernas.

A análise econômica-financeira efetuada, indica que è viável executar modificações nos processos visando elevar a eficiência energética nas unidades de Camaçari, BA e Laranjeiras, SE. Para a unidade de Piaçaguera, SP, as medidas de conservação de energia propostas não apresentaram viabilidade econômica. Os resultados obtidos foram:

- unidade Camaçari, BA: economia estimada de 17.476 t gás natural/ano ou $846.000 \mathrm{MMBtu} / \mathrm{ano}$, através de instalação de processo de recuperação de gás de purga (US\$2,24/MMBtu economizado), da modificação no reator de síntese (US\$0,95/MMBtu economizado) e de instalação de processo de pré aquecimento do ar de combustão (US\$1,69/MMBtu economizado).

- unidade Laranjeiras, SE: economia estimada de 12.018 t gás natural/ano ou 527.340 MMBtu/ano, através de instalação de processo de recuperação de gás de purga (US\$2,24/MMBtu economizado) e da modificação no reator de sintese (US\$0,95/MMBtu economizado)

Caso se executem as modificações, a média brasileira de consumo energético para produção de amônia reduzirá em 2,84\%, passando de 36,89 para 35,84 GJ/t NH N $_{3}$ Além deste efeito direto, a melhora da eficiência energética na produção de amônia provocaria redução de 7 a $18 \%$ no consumo de energia para fabricação dos FMN. Este fato indica que existe um efeito positivo ao longo da cadeia industrial de produção de FMN e consequentemente no segmento final - setor agricola - quando ocorre um aumento da eficiência energética no inicio do processo. $O$ resultado final é a diminuição dos efeitos negativos nos ciclos do carbono e do nitrogênio. 
A técnica de construção de cenários demonstrou ser útil para a previsão da demanda de FMN na cultura do milho, inserindo ou não o que se denominou opções de economia deste insumo. Foi possivel, também, identificar os custos envolvidos com a adoção das opções de utilização eficiente de nitrogênio, relacionando-os ao seu potencial de economizar FMN e energia.

\section{Demanda de Nitrogênio}

Existe um desequilibrio no consumo de fertilizantes minerais nitrogenados entre as culturas cultivadas no Brasil. Na média geral brasileira, aplica-se uma quantidade inferior ao que está se retirando com as colheitas.

Na simulação efetuada onde estipulou-se que a proporção da área com milho que emprega N-FMN e a eficiência de utilização dos FMN não mudariam (cenário Referência I), a demanda estimada por nitrogênio chega a 430.139 t $\mathrm{N}$ no ano de 2010 , partindo de um requerimento de 191.670 t N em 1995. Neste contexto, a adoção da incorporação dos FMN ao solo na adubação de cobertura por parte dos agricultores provocaria uma redução de $0,75 \%$ na demanda de N-FMN em 2010. No caso dos agricultores optarem pela adubação verde como fonte de nitrogênio, esta redução na demanda de N-FMN poderia atingir 5,9\%. Em termos de área, calculou-se que é necessário que 321.979 ha dos 14.481 .280 ha que estarão cultivando milho em 2010, adotem as medidas de economia de N-FMN propostas para alcançar estes resultados,

No caso de aumento da proporção da área com milho que emprega N-FMN e de não se adotarem medidas de uso eficiente dos FMN, estimou-se que a demanda de $\mathrm{N}$ para a cultura do milho em 2010 pode chegar a $959.907 \mathrm{t} \mathrm{N}$, o que está próximo do consumo total de nitrogênio para 0 Brasil em 1996: 1.197.357 t N. A adoção de medidas de economia de N-FMN em 4.321.206 ha dos 14.481.280 ha cultivados com milho em 2010 pode gerar uma redução na demanda de N-FMN de $13,7 \%$ quando a opção for a substituição por adubação verde e de $3 \%$ quando a opção for a incorporação dos FMN em cobertura.

Com relação a produção de milho, verificou-se que o aumento da proporção da área plantada com milho que emprega N-FMN ao longo dos anos, inserindo ou não medidas de uso eficiente do N-FMN, pode, no ano de 2010 , elevar a produção brasileira do cereal em $39 \%$ (63 milhões de t) quando comparada a situação de não se modificar a proporção atual da área cultivada com o cereal que emprega N-FMN (produção de 45 milhões de t).

O potencial de economia de N-FMN através da incorporação dos FMN ao solo é pequeno: 25.413 t N para uma demanda máxima estimada de 959.907 t $\mathrm{N}$ em 2008 . Entretanto, o custo 
calculado de se economizar N-FMN através da adoção desta técnica é equivalente a US\$0,04/kg N economizado. Quando os custos evitados são internalizados nos cálculos, o custo de ecomizar NFMN torna-se negativo: - US\$0,38/kg N economizado. Tal opção pode beneficiar o produtor pela melhora no rendimento econômico da cultura.

A adubação verde é capaz de evitar o consumo de hidrocarbonetos porque substitui o uso de FMN. Porém, ainda é uma opção mais cara que a fonte tradicional (média de US\$1,65/kg N economizado contra US\$0,42/kgN importado na forma de uréia) quando não se consideram os demais benefícios que ela provoca no sistema de produção agricola. A produção de sementes de adubo verde na propriedade agrícola é uma altemativa que torna o custo de se economizar N-FMN menor do que o custo de se utilizá-lo: US\$0,39/kg N economizado.

A baixa oferta de sementes para adubação verde no país é um outro fator que influencia no custo desta prática.

\section{Repercussões Ambientais}

As medidas de eficiência analisadas neste estudo resultam, de maneira geral, em uma redução nas emissões de dióxido de carbono e dos demais gases emitidos durante a produção de amônia, em consequência da redução quantitativa da energia necessária para produzir $1 \mathrm{t}$ deste produto. A diminuição total das emissões seria de 44.214 t $\mathrm{CO}_{2} /$ ano e de 60,46 t NO $\mathrm{N}_{\mathrm{x}}$ /ano.

A adoção de medidas de economia de N-FMN na agricultura possibilitam reduzir as emissões de $\mathrm{CO}_{2}$ e $\mathrm{NO}_{x}$ no ano de $2010 \mathrm{em}$ :

- 5.101 t $\mathrm{CO}_{2}$ e 6,6 t NO para o Cenário Manejo Eficiente I.

- $40.190 \mathrm{t} \mathrm{CO}_{2}$ e $52 \mathrm{t} \mathrm{NO}_{x}$ para o Cenário Adubação Verde l.

- 22.645 t $\mathrm{CO}_{2}$ e $30 \mathrm{t} \mathrm{NO}$ para o Cenário Simultâneo l.

- 40.259 t de $\mathrm{CO}_{2}$ e 52 t de NO para o Cenário Manejo Eficiente ll.

- 208.736 t de $\mathrm{CO}_{2}$ e de 272 t de $\mathrm{NO}_{x}$ para o Cenário Adubação Verde ll.

- 124.498 t $\mathrm{CO}_{2}$ e 162 t de $\mathrm{NO}_{x}$ para o Cenário Simultâneo II.

Com relação ao ciclo do nitrogênio, sendo a produção e utilização de fertilizantes minerais nitrogenados seu principal fator de distúrbio, qualquer medida que leve à diminuição do desperdício será positiva no sentido de reduzir os impactos negativos gerados.

Como o manejo eficiente do FMN reduz a quantidade necessária a ser aplicada, colabora para evitar um aumento ainda maior do montante de nitrogênio fixado.

A difusão da prática de adubação verde, implicando no aumento da área plantada com leguminosas, apesar de ser considerado o segundo fator em ordem de importância responsável pela 
duplicação da quantidade de nitrogênio fixada nas últimas décadas, tem a caracteristica de não fomecer uma grande concentração de nutriente quando comparada ao FMN e, por isso, não produz um excedente de nitrogênio que as raizes não são capazes de absorver e que acabam sendo perdidos em consequência de fatores edafoclimáticos (chuvas intensas, estiagens, estrutura do solo).

No que concerne à emissão de $\mathrm{N}_{2} \mathrm{O}$, não existe diferença entre a fonte mineral e biológica, pois os processos de transformação bioquímicos que ambas sofrem são semelhantes.

\subsection{Suqestōes}

O fornecimento de nitrogênio para a agricultura deve ser objeto de planejamento, porque 0 fato da fonte mineral ser a mais utilizada representa uma dependência por um insumo de valor energético elevado e associado a interferências ambientais negativas.

No atual contexto de busca de sistemas de produção mais equilibrados social, econômico e ambientalmente, não se permite ignorar a diversidade de opções de modos de produção que introduzam outras fontes de nitrogênio como a adubação orgânica e a adubação verde.

Buscar este equilibrio não significa excluir a opção pelo FMN, mas simplesmente alcançar padrões que permitam um desperdicio reduzido deste insumo. Sabe-se que não é viável uma substituição total da fonte mineral de nitrogênio por fontes renováveis. A questão é torná-lo disponivel pelo tempo mais longo possivel e tornar comercializáveis outras fontes de nitrogênio, para não provocar uma mudança abrupta e desestruturada na atividade agrícola.

A pesquisa acadêmica há muito já se sensibiliza com esta questão produzindo a base mais do que necessária para assegurar a eficácia de tais opções "altemativas". Até mesmo a transferência destes conhecimentos já vem sendo feita pelos serviços de extensão rural.

Nota-se, porém, uma reduzida taxa de adoção destas práticas entre os agricultores, que pode ser consequência da falta de estímulos para a transformação dos agroecossistemas.

As regras para o financiamento agricola podem ser as ferramentas necessárias para a modificação do quadro atual. Um exemplo seriam as modificações feitas pelo governo federal, como a associação do zoneamento pedoclimático à concessão de crédito para custeio das safras de algumas culturas e regiões do pais (FURTADO \& BEZERRA, 1998). Isto é importante porque 0 melhor conhecimento da área a ser cultivada propicia uma incerteza menor quanto ao resultado da produção, e também permite verificar a possibilidade de se adotar a prática de adubação verde, além de indicar a melhor época e espécie de adubo verde a ser utilizada. 
O zoneamento já propicia uma diferenciação nas taxas de juros cobradas nos empréstimos: 0 agricultor que decidir seguir as recomendações é beneficiado com menores taxas. A inserção da prática da adubação verde pode ser estimulada através de taxas de juros menores para os agricultores que optarem por esta prática. Assim como indices de produtividade podem também estar associados ao crédito, como: quantidade de fertilizante adquirida/produção obtida; quantidade de fertilizante aplicada por hectare/produtividade obtida da cultura.

Outro fator a ser considerado no planejamento é a diferença Norte-Sul em termos de produtividade agricola e uso de insumos (no caso, ressaltando a importância do nitrogênio). Para reduzir estas diferenças, em locais onde as condições naturais propiciem o uso da adubação verde e o custo de transporte do FMN, devido à distância, seja elevado, deve-se priorizar o estímulo à utilização da fonte biológica.

Para efeito de comparação, podem-se criar alguns indices que subsidiem a escolha da fonte de nitrogênio a ser produzida. A indústria produtora de amônia e uma empresa produtora de sementes para adubação verde podem ser comparadas da seguinte maneira:

a) Uma unidade de amônia requer um grande volume de capital para ser financiada, enquanto uma empresa produtora de sementes não.

b) A produção de amônia e fertilizantes deve ser concentrada em uma área e depois distribuída. Uma empresa produtora de sementes deve ser regionalizada para que seu produto seja desenvolvido de acordo com as condições naturais da região.

c) A produção de amônia resulta em emissões de dióxido de carbono e com uma empresa que comercializa sementes isso não acontece.

d) A produção e comercialização de sementes de adubo verde pode ser feita através da união de um grupo de produtores, gerando uma renda adicional à propriedade agricola. Por outro lado, os agricultores não teriam força econômica e tecnológica para construir uma unidade de amônia.

e) Uma empresa de sementes, por ser regional, pode gerar impostos para a própria região onde 0 insumo vai ser consumido. A indústria gera a renda do imposto no seu local de produção e o FMN tem de ser transportado para a região de consumo.

f) Ambas opções dependem de recursos não renováveis: a indústria de fertilizantes, do gás natural e a empresa de sementes, do solo. A diferença é que o uso do solo não representa custos diretos na produção.

A conscientização do agricultor no que se refere às relações práticas agricolas - equilibrio do meio ambiente - retorno econômico jả faz parte de prioridades politicas a nivel intemacional e 
nacional. Entretanto, a fase de implementação de novas diretrizes para o desenvolvimento de sistemas agricolas que provoquem menos impactos negativos ao meio ambiente ainda está distante. Esta é uma questão fundamentalmente ligada à educação e, portanto, uma ação de longo prazo, que significa mudança de comportamento e que se depara com inúmeras barreiras. Considera-se, porém, que esta é a ação que pode promover os resultados mais sólidos.

Antes de conscientizar, porém é preciso ter em mente que:

" $A$ inserção de qualquer nova tecnologia em um meio social deve ser precedida não somente de um estudo de sua viabilidade técnica e econômica, mas também de uma análise global quantitativa e qualitativa da realidade das populações a serem atingidas, visando também 0 envolvimento e a participação dos usuários. Ignorar estes parâmetros seria apostar contra a própria sustentabilidade." (FEDRIZZI, 1997).

\subsection{Trabalhos Futuros}

Esta dissertação não esgota a análise da demanda de nitrogênio nem suas opções de uso eficiente, seus custos e aspectos ambientais; pelo contrário, suscita a necessidade de se ampliar os estudos em inúmeros aspectos. Entre eles, pode-se indicar:

- a condução de estudos por região geográfica e não do Brasil todo.

- a possibilidade de se realizar experimentos com a avaliação integral dos impactos positivos e negativos que a utilização de determinada fonte de nitrogênio pode provocar - no meio ambiente, na economia e na melhora da produtividade agrícola.

- a necessidade de se efetuar os cálculos de demanda de nitrogênio para todas as culturas, enfocando a agricultura como um todo.

- na construção dos cenários, inserir todas as fontes de nitrogênio disponiveis sob o aspecto viabilidade tecnológica. Por exemplo, os compostos orgânicos provenientes de residuos agrícolas elou urbanos e o esterco animal.

- além de considerar todas as fontes de $\mathrm{N}$ disponiveis, trabalhos futuros devem analisar as várias opções de manejo do FMN que constam do conhecimento empírico e acadêmico.

A importância de se efetuar o planejamento do uso de recursos na agricultura e de sua aplicação mediante criação de políticas agricolas deve ser objeto de estudos a curto e longo prazo. Estes estudos podem proporcionar a criação de metas que incluam as exigências para se atingir o desenvolvimento sustentável, na medida que inserem demandas ambientais e sociais na formulação de politicas agricolas. 
ANEXO - 1 


\section{PROCESSO DE SINTTESE DE AMÔNIA REFORMA CATALÍTICA COM VAPOR D'ÁGUA}

(CEKINSKI et al., 1990).

A reação de reforma com vapor é endotérmica, sendo processada num forno chamado reformador primário onde o calor é suprido pela queima de combustivel. Segundo a disponibilidade, pode ser utilizado como combustivel: gás natural, nafta, gás de refinaria e óleo combustivel.

A evolução da tecnologia de reforma está associada ao desenvolvimento tecnológico do reformador primário, tanto do ponto de vista térmico como mecânico.

O reformador primário é um equipamento que apresenta duas zonas bem delimitadas: - zona de radiação, composta de tubos enfileirados recheados com catalisador, possui como elemento ativo o niquel, que catalisa a reação entre o vapor d'água e o metano, alimentados na relação vapor carbono $V / C 3,7: 1$ onde, a temperaturas na ordem de $820^{\circ} \mathrm{C}$ e pressões de 30 a 35 atm, o metano é convertido em $\mathrm{H}, \mathrm{CO}$ e $\mathrm{CO}_{2}$. a energia necessária à reação é fornecida pela queima de combustivel nos queimadores localizados nesta zona do forno

- zona de conveç̧ão é onde o calor convectivo gerado na combustão é recuperado, alcançando uma eficiência de recuperação da ordem de 83 a $87 \%$. Na zona de conveç̧ão são pré aquecidos o ar alimentado ao reformador secundário, a matéria-prima que entra nos tubos do reformador que entra nos tubos do reformador primário e a água de caldeira. $O$ vapor de alta pressão gerado no processo é utilizado para fornecer energia mecânica ao compressor de gás de sintese.

Há no mercado vários fornecedores deste equipamento, como Kellog, Unde, Exxon, Foster Wheeler, Haldor Topsoe.

A figura 1 é apresentada para uma melhor compreensão do processo.

Não é possivel obter a conversão total do metano em hidrogênio nas condições de operação do reformador primário. Normalmente, o teor de metano residual oscila entre 6 e $10 \%$, em pressões da ordem de 27 a $37 \mathrm{~atm}$.

Para reduzir o teor de metano a valores abaixo do limite tolerado no "loop" de síntese (da ordem de $0,25 \%$ ), è necessário colocar a jusante do reformador primário um equipamento, 0 reformador secundário, que permite a redução do teor de metano até os niveis exigidos pelo processo.

Neste reator adiabático, onde os gases quentes que saem do reformador primário reagem com 0 ar pre aquecido na zona de conveç̧ão do reformador primário, a temperatura é sustentada 
pela reação de combustão do oxigênio do ar com o residual de metano, o hidrogênio e o monóxido de carbono, em presença do catalisador de níquel. Aqui, os gases livres de metano, a uma temperatura da ordem de $950^{\circ} \mathrm{C}$, incorporam o nitrogênio do ar necessário para se obter a relação estequiométrica do gás de sintese.

Figura 1. Processo de reforma catalitica com vapor d'água.

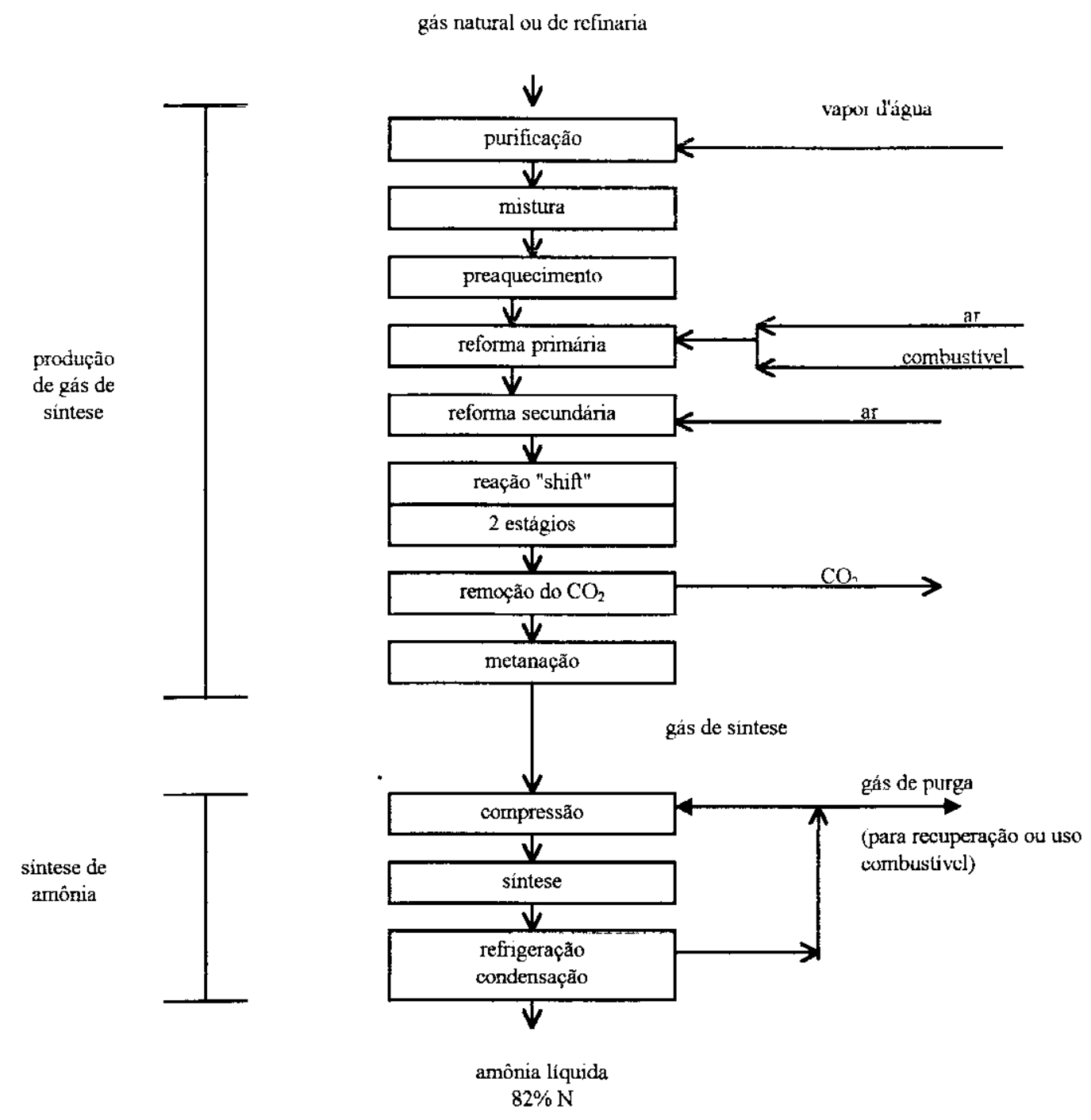

fonte: BRUNO et al. (1985).

Posteriormente, os gases contendo hidrogênio, nitrogênio e gás carbônico são resfriados na caldeira de recuperação de calor até aproximadamente $350^{\circ} \mathrm{C}$, mediante a geração de vapor de alta pressão (100atm) necessária para o acionamento da turbina do compressor de gás de sintese, para posteriormente entrar na etapa de conversão do CO com vapor d'água em gás carbônico e 
hidrogênio. Nesta etapa, o gás é convertido em dois reatores de deslocamento de gás d'água ("water gás shiff") de alta temperatura e de baixa temperatura, que contém catalisador de ferro e cromo, respectivamente. Assim, após esta etapa, o gás contém hidrogênio, nitrogênio, gás carbônico, monóxido de carbono $(0,25 \%)$ e metano $(0,3 \%)$.

$\mathrm{O} \mathrm{CO}_{2}$ é removido da corrente de gás na etapa de denominada "remoção de $\mathrm{CO}_{2}$ " através de vários solventes, entre os quais as soluções de carbonato de potássio, que ativado com diferentes compostos dá lugar aos diferentes processos de remoção. Se ativado com arsênico, temse o processo Vetrocoke, se ativado com etanolamina, o processo Benfield, e se ativado com um composto orgânico, o processo Catacarb. Também são utilizados como solventes as etanolaminas e derivados, caracterizando o processo MDEA.

Após a etapa de remoção de $\mathrm{CO}_{2}, 0$ gás de síntese é purificado para eliminar os vestigios de $\mathrm{CO}_{\text {e } \mathrm{CO}_{2}}$ na etapa de metanação, onde os óxidos de carbono, que são venenos do catalisador da sintese de amônia, são convertidos num reator catalítico em metano e água. 0 gás final, contendo aproximadamente $1 \%$ de metano, chamado gás de sintese puro, está pronto para ser comprimido até a pressão de sintese de amônia. A pressão do gás neste ponto é da ordem de 23 a $33 \mathrm{~atm}$.

Sintese de amônia (BRUNO et al. 1985).

Qualquer que seja o processo de preparação do gás de síntese, é utilizada a tecnologia Haber-Bosh para a sintese da amônia, incluindo o sistema de compressão dos gases.

Como mencionado previamente, a sintese de amônia é realizada à temperatura de $400 \mathrm{a}$ $450^{\circ} \mathrm{C}$, utilizando um catalisador de ferro ativado com potássio suportado em alumina. $\mathrm{O}$ gás que entra no conversor consiste principalmente do gás que circula no ciclo da síntese com uma pequena quantidade de gás de reposição ("make-up gas"). 0 gás que entra no conversor contém nitrogênio e hidrogênio na relação molar 1:3, além de 10 a 14\% de "inertes" e 2\% de amônia. Os "inertes" são constituídos principalmente de metano, argônio $\mathrm{e}$, às vezes pequena quantidade de hélio. $O$ metano não é efetivamente um gás inerte, mas ele não participa da reação. Considerando-se que a concentração de gases inertes tende a aumentar à medida em que se remove $\mathrm{N}_{2}$ e $\mathrm{H}_{2}$, toma-se necessário proceder-se à extração de inertes, a fim de se manter a concentração dos mesmos num nivel tolerável dentro do conversor. Este fluxo extraído é denominado "gás de purga".

Os conversores de sintese de amônia são de dois tipos:

- aqueles que têm múltiplos leitos de catálise, onde ocorre o resfriamento dos gases entre os leitos para geração de vapor, ou para preaquecimento do gás de alimentação; 
- aqueles que têm um leito de catálise contínuo, onde o calor da reação é removido por meio de um trocador de calor.

O gás que deixa o conversor contém cerca de 12 a $18 \%$ de amônia, dependendo principalmente da pressão. Este gás é primeiramente resfriado por troca de calor com o gás de entrada na unidade de sintese e, finalmente, entra na unidade de refrigeração para condensar a maior parte de $\mathrm{NH}_{3} . \mathrm{O}$ grau de resfriamento necessário depende da pressão. Se a amônia deve ser produzida na pressão de estocagem igual à atmosférica, deve ser resfriada a $-33^{\circ} \mathrm{C}$. $O$ gás remanescente, após condensação da amônia, é reciclado ao conversor por meio de um compressor. 
ANEXO - 2 


\section{QUESTIONÁRIO}

Antes de propriamente efetuar perguntas, gostaria que os dados fornecidos a seguir fossem confirmados ou, quando necessário, corrigidos.

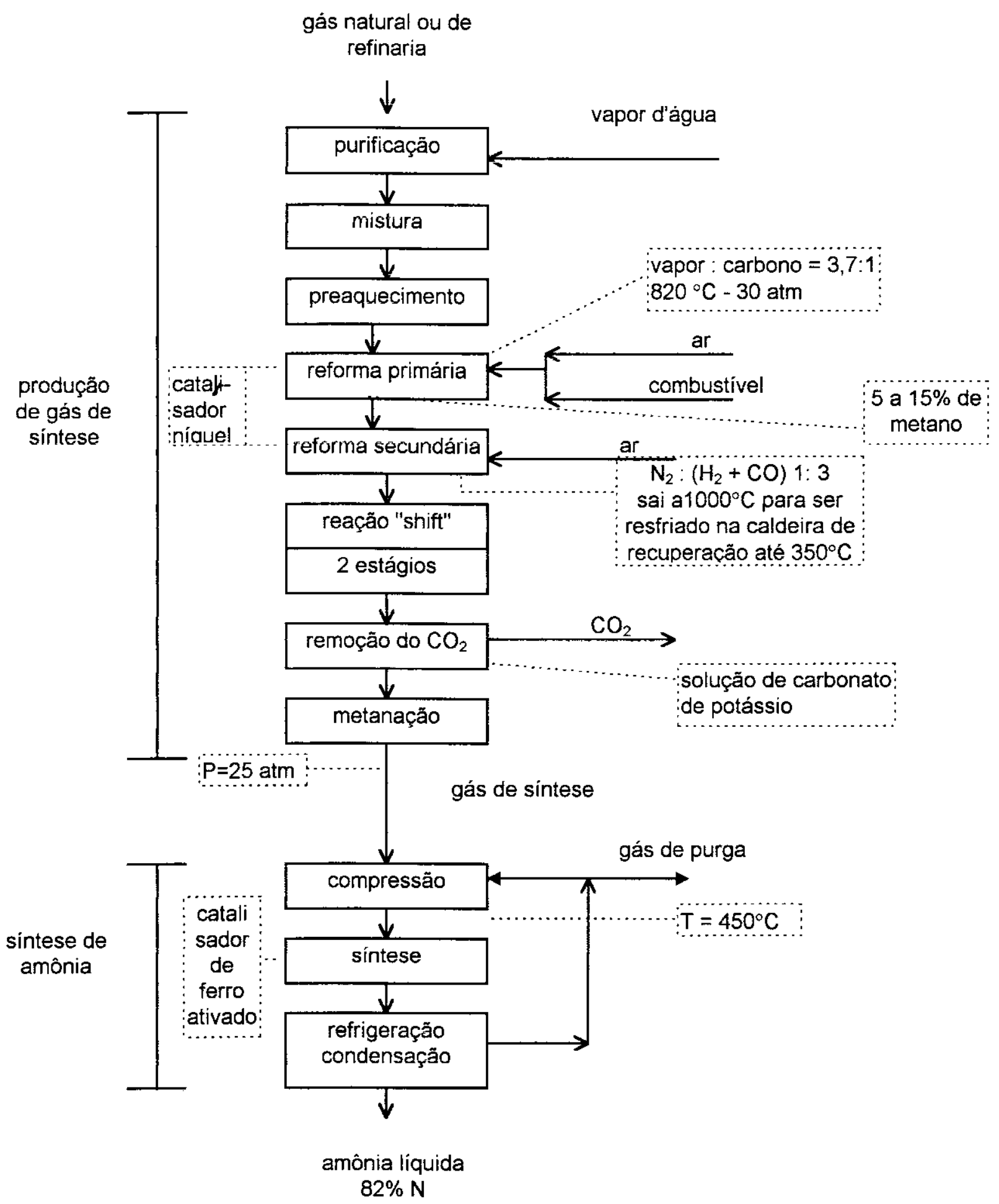


Peço que efetuem, se necessário, correções nos dados da tabela abaixo.

\begin{tabular}{|c|c|c|c|c|}
\hline $\begin{array}{c}\text { empresa / } \\
\text { capacidade }\end{array}$ & $\begin{array}{c}\text { local / } \\
\text { instalacão }\end{array}$ & matéria-prima & $\begin{array}{l}\text { tecnologia } \\
\text { gás de síntese } \\
\text { (licenciador) }\end{array}$ & $\begin{array}{c}\text { tecnologia } \\
\text { síntese } \\
\text { (licenciador) }\end{array}$ \\
\hline $\begin{array}{c}\text { ULTRAFERTI } \\
\mathrm{L} \\
520 \mathrm{t} / \mathrm{d}\end{array}$ & $\begin{array}{l}\text { Piaçaguera, SP } \\
\text { (1970) }\end{array}$ & Gás de refinaria & $\begin{array}{l}\text { reforma com vapor } \\
\text { FOSTER } \\
\text { WHEELER(30atm) }\end{array}$ & $\mathrm{ICl}(140 \mathrm{~atm})$ \\
\hline $\begin{array}{c}\text { ULTRAFERTI } \\
\mathrm{L} \\
1200 \mathrm{t} / \mathrm{d}\end{array}$ & $\begin{array}{c}\text { Araucária, SP } \\
\text { (1982) }\end{array}$ & $\begin{array}{l}\text { Resíduo } \\
\text { asfáltico }\end{array}$ & $\begin{array}{c}\text { oxidação parcial } \\
\text { SHELL/LURGI } \\
(47 \mathrm{~atm})\end{array}$ & $\begin{array}{l}\text { KOBE STEEL/UHDE } \\
\text { (220atm } \\
\text { HALDOR-TOPSOE }\end{array}$ \\
\hline $\begin{array}{c}\text { Petrobrás } 1100 \\
t / d\end{array}$ & $\begin{array}{c}\text { Camaçari, BA } \\
\text { (1978) }\end{array}$ & Gás natural & $\begin{array}{l}\text { reforma com vapor } \\
\text { KELLOGG (34atm) }\end{array}$ & $\begin{array}{l}\text { KELLOGG } \\
\text { (140atm) }\end{array}$ \\
\hline $\begin{array}{c}\text { Petrobrás } \\
1000 t / d\end{array}$ & $\begin{array}{c}\text { Larangeiras, SE } \\
\text { (1982) }\end{array}$ & $\begin{array}{l}\text { Gás natural } \\
\text { assoc. }\end{array}$ & $\begin{array}{l}\text { reforma com vapor } \\
\text { KELLOGG (34atm) }\end{array}$ & $\begin{array}{c}\text { KELLOGG } \\
(140 \mathrm{~atm})\end{array}$ \\
\hline
\end{tabular}

fonte: adaptado de CEKINSKI (1990) e BRUNO et al. (1985).

Seguem, finalmente, as questões.

1) Existe na Empresa uma Comissão Interna ou Setor de Conservação de Energia, responsável por monitorar o desempenho do processo em termos de consumo de energia?

2) Através da Comissão acima citada (se existente) ou empresa externa, foi feita uma auditoria energética nos últimos tempos? Constatou-se a existência de potencial de conservação de energia nos processos? Qual?

3) Com relação ao processo:

- consumo de combustivel (t ou $\mathrm{m}^{3}$ ou Mmbtu ou Gcal / ano)

- consumo de eletricidade (kWh / ano)

- consumo de vapor direto e indireto

- consumo de matéria-prima (t ou $\mathrm{m}^{3}$ ou Mmbtu ou Gcal / ano)

- produção de amônia (t / ano)

4) Existe o pré aquecimento do ar de combustão na fornalha do reformador primário? Em que temperatura?

5) Existe processo de recuperação de hidrogênio do gás de purga? Qual o tipo de processo e qual a quantidade recuperada?

6) Efetua-se a recuperação de calor dos gases de combustão da fornalha do reformador primário? Qual o montante recuperado?

7) Com relação a etapa de sintese de amônia, favor confirmar a existência de:

- compressor centrifugo acionado por turbinas a vapor.

- reator axial com "quench" de resfriamento entre leitos.

- dois estágios de condensação de amônia. 
ANEXO - 3 
custo da instalação do pré aquecimento do gás de combustão

\begin{tabular}{|c|c|c|c|c|c|}
\hline & & vida útil equip. & & anos & conversão DEM p/ US\$ \\
\hline & $\sqrt{\text { Invest. inicial }}$ & pré aquecimento & $4.550 .000,00$ & DEM & \multirow{14}{*}{$\begin{array}{ll}\text { divide por } & 1,806 \\
\text { cotação OESP } & 13 / 06 / 98\end{array}$} \\
\hline & & pré aquecimento & 2.519 .379 .84 & US\$ & \\
\hline & & pré aquecimento & 14,68 & $\mathrm{U} \$ \mathrm{t} / \mathrm{NH}_{3}$ & \\
\hline & O\&M & total & 0,00 & $\mathrm{U} \$ \mathrm{t} / \mathrm{NH}_{3}$ & \\
\hline & O\&M & total2 & 0,00 & U\$ ano & \\
\hline & taxa de desconto & & & $\%$ & \\
\hline $\mathrm{CCV}$ & valor F/P & 0,061100279 & & & \\
\hline & Inves.inicial & $2.519 .379,84$ & & & \\
\hline & vida útil equip. & 20 & & & \\
\hline & Invest. inicial & $2.519 .379,84$ & & & \\
\hline & $O \& M$ & 0,00 & & & \\
\hline & $\mathrm{CCV}$ & $2.519 .379,84$ & & & \\
\hline & FRC & 0,15976147 & & & \\
\hline & CCVA & $402.499,83$ & U\$ano & & \\
\hline & ENERGIA ECONO & MIZADA & & & \\
\hline & $\begin{array}{r}0.80 \\
\end{array}$ & $\mathrm{GJ} / \mathrm{t} \mathrm{NH}_{3}$ & & & \\
\hline & 137280 & GJ/ano & & & \\
\hline & 2,93 & U\$ $\$$ GJ economizado & & & \\
\hline
\end{tabular}

custo da instalação do pré aquecimento do gás de combustáo

unidade de Piaçaguera =

$171600 \mathrm{t} \mathrm{NH}_{3}$ ano

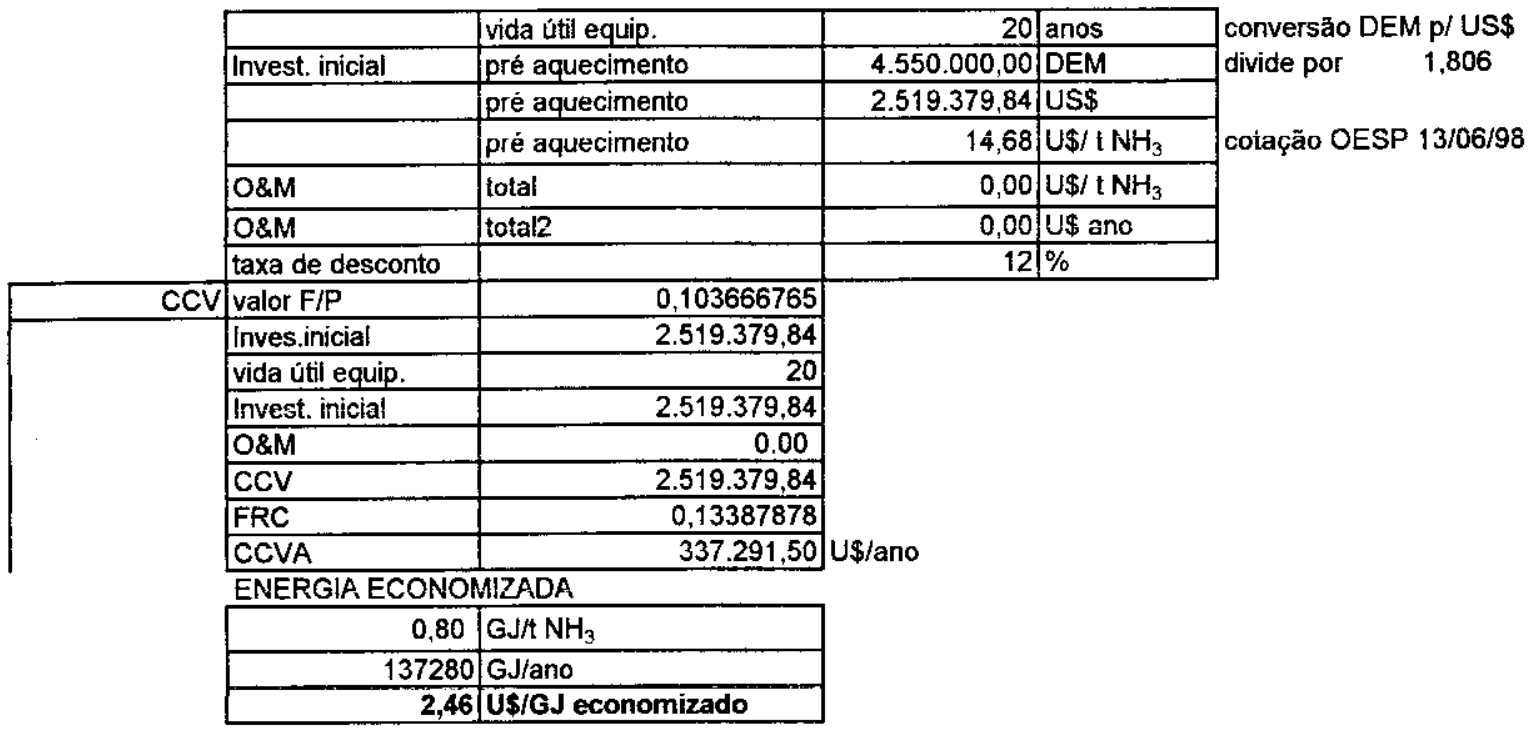

custo da instalação do pré aquecimento do gás de combustăo

unidade de Piaçaguera =

$171600 \mathrm{t} \mathrm{NH}_{3}$ ano

\begin{tabular}{|c|c|c|c|c|c|}
\hline & & vida útil equip. & & anos & \multirow{2}{*}{$\begin{array}{l}\text { conversão DEM p/ US\$ } \\
\text { divide por } \quad 1,806\end{array}$} \\
\hline & Invest. inicial & pré aquecimento & $4.550 .000,00$ & DEM & \\
\hline & & pré aquecimento & $2.519 .379,84$ & US\$ & \multirow{5}{*}{ cotação OESP $13 / 06 / 98$} \\
\hline & & pré aquecirnento & 14,68 & $\mathrm{U} \$ / \mathrm{NH}_{3}$ & \\
\hline & O\&M & total & 0,00 & $\mathrm{U} \$ \mathrm{t} \mathrm{NH}_{3}$ & \\
\hline & $O \& M$ & total2 & \multirow{2}{*}{\multicolumn{2}{|c|}{$\begin{array}{c}0.00 \\
10\end{array}$}} & \\
\hline & \multirow{2}{*}{\begin{tabular}{|l} 
taxa de desconto \\
valor F/P
\end{tabular}} & & & & \\
\hline \multirow{12}{*}{ CCV } & & 0,148643628 & & \\
\hline & Inves.inicial & $2.519 .379,84$ & \multirow{11}{*}{\multicolumn{2}{|c|}{ U\$/ano }} & \\
\hline & vida útil equip. & 20 & & & \\
\hline & Invest. inicial & $2.519 .379,84$ & & & \\
\hline & O\&M & 0,00 & & & \\
\hline & $\mathrm{CCV}$ & $2.519 .379,84$ & & & \\
\hline & FRC & 0,117459625 & & & \\
\hline & CCVA & $295.925,41$ & & & \\
\hline & \multicolumn{2}{|c|}{ ENERGIA ECONOMI7ZADA } & & & \\
\hline & $\begin{array}{r}0,80 \\
\end{array}$ & $\mathrm{GJ} / \mathrm{t} \mathrm{NH}$ & & & \\
\hline & 137280 & \multirow{2}{*}{$\begin{array}{l}\text { GJ/ano } \\
\text { US/GJ economizado }\end{array}$} & & & \\
\hline & 2,16 & & & & \\
\hline
\end{tabular}


custo da modificação no reator de síntese

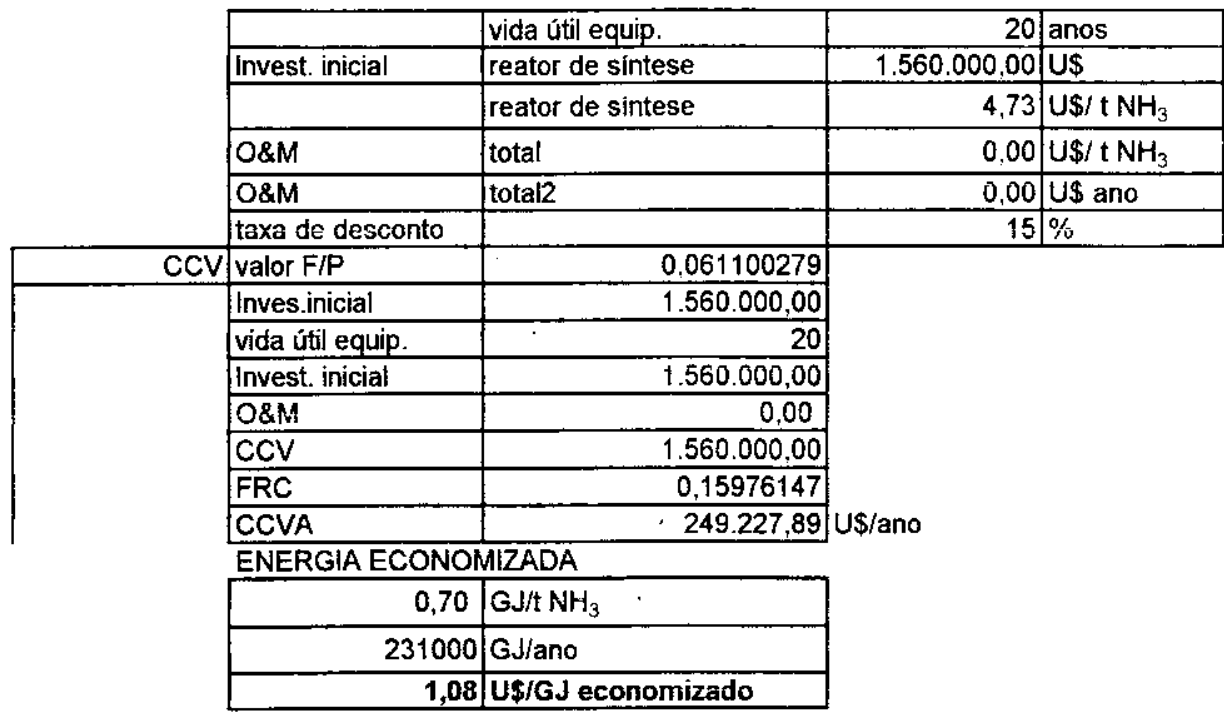

custo da modificação no reator de sintese supondo unidade de 1000 tpd $\mathrm{NH}_{3}=$

$330000+\mathrm{NH}_{3}$ ano

\begin{tabular}{|c|c|c|c|c|}
\hline & & vida útil equip. & 20 & anos \\
\hline & Invest. inicial & reator de sintese & $1.560 .000,00$ & U\$ \\
\hline & & reator de sintese & 4,73 & $\mathrm{U} \$ / \mathrm{t} \mathrm{NH}_{3}$ \\
\hline & O\&M & total & 0,00 & $\mathrm{U} \$ / \mathrm{t} \mathrm{NH}_{3}$ \\
\hline & $O \& M$ & total2 & 0,00 & U\$ ano \\
\hline & taxa de desconto & & 12 & $\%$ \\
\hline \multirow{12}{*}{ CCV } & valor $F / P$ & 0,103666765 & \multirow{12}{*}{ U\$/ano } & \\
\hline & Inves.inicial & $1.560 .000,00$ & & \\
\hline & vida útil equip. & 20 & & \\
\hline & Invest. inicial & $1.560 .000,00$ & & \\
\hline & O\&M & 0,00 & & \\
\hline & $\mathrm{CCV}$ & 1.560 .000 .00 & & \\
\hline & FRC & 0,13387878 & & \\
\hline & CCVA & 208.850 .90 & & \\
\hline & \multicolumn{2}{|c|}{ ENERGIA ECONOMIZADA } & & \\
\hline & 0,70 & $\mathrm{GJ} / \mathrm{t} \mathrm{NH}_{3}$ & & \\
\hline & 231000 & GJ/ano & & \\
\hline & 0,90 & U\$/GJ economizado & & \\
\hline
\end{tabular}

custo da modificação no reator de sintese

Camaçari e Laranjeiras $=$

$330000+\mathrm{NH}_{3}$ ano

\begin{tabular}{|c|c|c|c|c|}
\hline & & vida útil equip. & 20 & anos \\
\hline & Invest. inicial & reator de síntese & $1.560 .000,00$ & US \\
\hline & & reator de sintese & 4,73 & $\mathrm{U} \$ / \mathrm{tNH}_{3}$ \\
\hline & O\&M & total & 0,00 & $\mathrm{U} \$ \mathrm{t} \mathrm{NH}_{3}$ \\
\hline & O\&M & total2 & 0,00 & U\$ ano \\
\hline & taxa de desconto & & 10 & $\%$ \\
\hline \multirow{12}{*}{ CCV } & valor F/P & 0,148643628 & & \\
\hline & Inves.inicial & $1.560 .000,00$ & & \\
\hline & vida útil equip. & 20 & & \\
\hline & Invest. inicial & $1.560 .000,00$ & & \\
\hline & $\mathrm{O \& M}$ & 0,00 & & \\
\hline & $\mathrm{CCV}$ & $1.560 .000,00$ & & \\
\hline & FRC & 0,117459625 & & \\
\hline & CCVA & $183.237,01$ & U\$/ano & \\
\hline & \multicolumn{2}{|c|}{ ENERGIA ECONOMIZADA } & & \\
\hline & 0,70 & $\mathrm{GJ} / \mathrm{t} \mathrm{NH}_{3}$ & & \\
\hline & 231000 & GJiano & & \\
\hline & 0,79 & U\$/GJ economizado & & \\
\hline
\end{tabular}


custo da instalação do recuperador de gás de purga, criogénica

unidade de Camaçari e Laranjeiras =

$330000 \mathrm{t} \mathrm{NH}_{3}$ ano

\begin{tabular}{|c|c|c|c|c|c|}
\hline & & vida útil equip. & 10 & anos & \multirow{2}{*}{$\begin{array}{l}\text { conversão DEM p/ US\$ } \\
\text { divide por } \quad 1,806\end{array}$} \\
\hline & Invest. inicial & recuperador gás de purga & $7.150 .000,00$ & DEM & \\
\hline & & recuperador gás de purga & $3.959 .025,47$ & US\$ & \multirow{5}{*}{ cotação OESP $13 / 06 / 98$} \\
\hline & & recuperador gás de purgà & $\lceil 2,00$ & $\mathrm{U} \$ / \mathrm{i} \mathrm{NH}_{3}$ & \\
\hline & O\&M & total & 0,00 & $\mathrm{U} \$ / \mathrm{NH}_{3}$ & \\
\hline & O\&M & total2 & \multicolumn{2}{|c|}{\begin{tabular}{l|l|}
0.00 & U $\$$ anc \\
\end{tabular}} & \\
\hline & taxa de desconto & & \multicolumn{2}{|c|}{$15 \%$} & \\
\hline $\operatorname{cCV}$ & valor F/P & 0,247184706 & & \\
\hline & inves.inicial & $3.959 .025,47$ & & & \\
\hline & vida útil equip. & 10 & & & \\
\hline & Invest. inicial & $3.959 .025,47$ & & & \\
\hline & $\mathrm{O} \& \mathrm{M}$ & 0,00 & & & \\
\hline & $\mathrm{CCV}$ & $3.959 .025,47$ & & & \\
\hline & FRC & 0,199252063 & & & \\
\hline & CCVA & $788.843,99$ & & & \\
\hline & \multicolumn{2}{|c|}{ ENERGIA ECONOMIZADA } & \multicolumn{2}{|l|}{ U\$/ano } & \\
\hline & 1,00 & $\mathrm{GJ} / \mathrm{t} \mathrm{NH}_{3}$ & & & \\
\hline & 330000 & GJ/ano & & & \\
\hline & 2,39 & U\$/GJ economizado & & & \\
\hline
\end{tabular}

custo da instalaçáo do recuperador de gás de purga, criogênica

unidade de Camaçari e Laranjeiras =

$330000 \mathrm{t} \mathrm{NH}_{3}$ ano

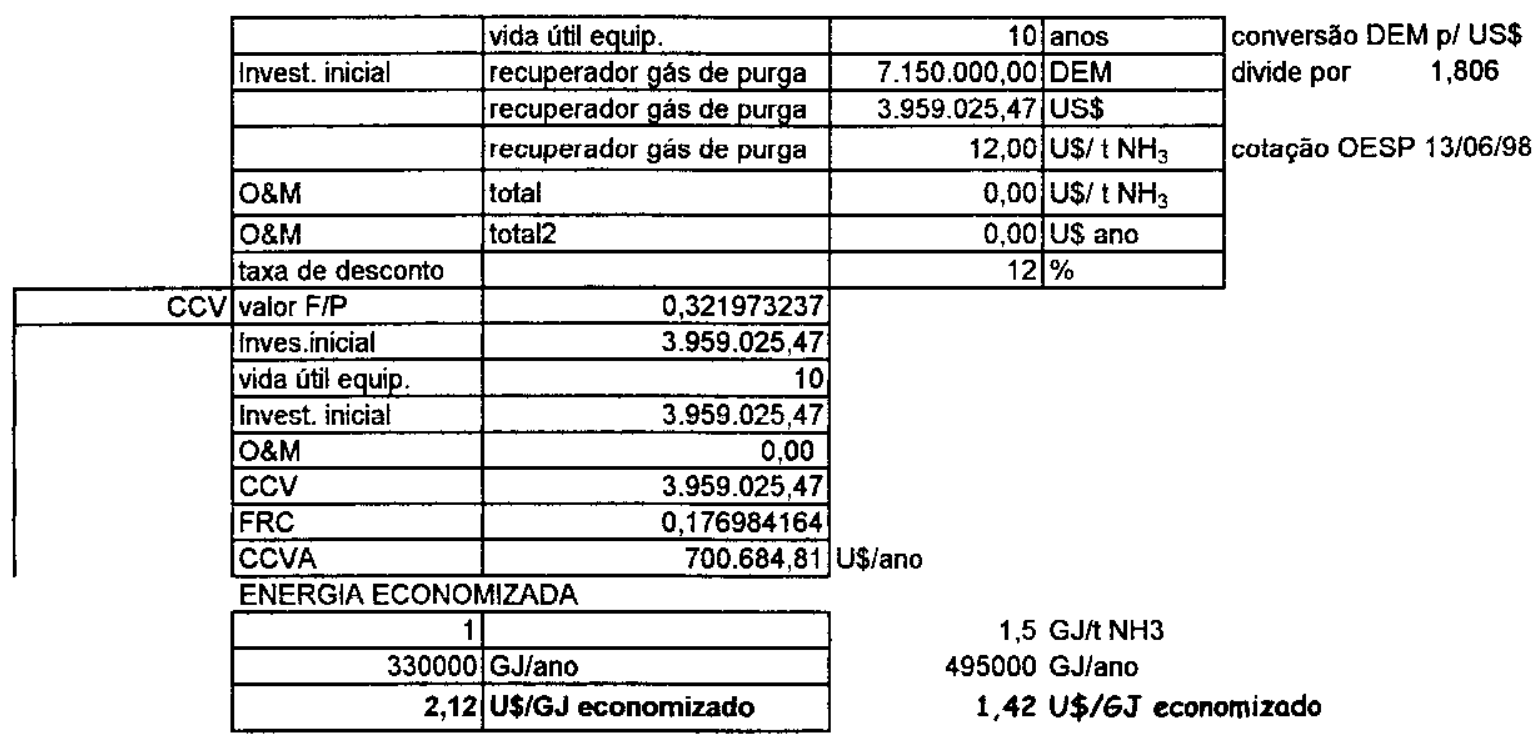

custo da instalaçăo do recuperador de gás de purga, criogênica

unidade de Camaçari e Laranjeiras $=$

$330000 \mathrm{t} \mathrm{NH}_{3}$ ano

\begin{tabular}{|c|c|c|c|c|c|}
\hline & & vida útil equip. & \multicolumn{2}{|c|}{\begin{tabular}{r|r|}
10 & anos \\
\end{tabular}} & \multirow{3}{*}{$\begin{array}{l}\text { conversão DEM p/ US\$ } \\
\text { divide por } 1,806\end{array}$} \\
\hline & invest. inicial & recuperador gás de purga & $7.150 .000,00$ & DEM & \\
\hline & & recuperador gás de purga & $3.959 .025,47$ & US\$ & \\
\hline & & recuperador gás de purga & 12,00 & $\mathrm{U} \$ / \mathrm{tNH}_{3}$ & cotação OESP $13 / 06 / 98$ \\
\hline & O\&M & total & 0,00 & $\mathrm{U} \$ / \mathrm{NH}_{3}$ & \\
\hline & O\&M & total2 & 0,00 & U\$ ano & \\
\hline & taxa de desconto & & 10 & $\%$ & \\
\hline $\mathrm{CCV}$ & valor F/P & 0,385543289 & & & \\
\hline & Inves.inicial & $3.959 .025,47$ & & & \\
\hline & vida útil equip. & 10 & & & \\
\hline & Invest. inicial & $3.959 .025,47$ & & & \\
\hline & $08 \mathrm{M}$ & 0.00 & & & \\
\hline & $\mathrm{CCV}$ & $3.959 .025,47$ & & & \\
\hline & FRC & 0,162745395 & & & \\
\hline & CCVA & $644.313,16$ & U\$iano & & \\
\hline & ENERGIA ECONON & MIZADA & & & \\
\hline & $\begin{array}{r}1,00 \\
\end{array}$ & GJ/t NH & & & \\
\hline & 330000 & GJ/ano & & & \\
\hline & 1,95 & US/GJ economizado & & & \\
\hline
\end{tabular}


custo da instalação do recuperador de gás de purga, membranas unidade de Piaçaguera $=$

171600 t $\mathrm{NH}_{3}$ ano

\begin{tabular}{|c|c|c|c|c|c|}
\hline & \multirow[b]{2}{*}{ Invest. inicial } & periodo de análise & \multirow{2}{*}{\multicolumn{2}{|c|}{\begin{tabular}{r|l|}
10 & anos \\
$2.340 .000,00$ & DEM
\end{tabular}}} & \multirow{3}{*}{$\begin{array}{l}\text { conversão DEM p/ US\$ } \\
\text { divide por } \\
\text { d,806 }\end{array}$} \\
\hline & & recuperador gás de purga & & & \\
\hline & & recuperador gás de purga & $1.295 .681,06$ & US\$ & \\
\hline & & recuperador gás de purga & 7,55 & $\mathrm{U} \$ / \mathrm{tNH}_{3}$ & coiação OESP 13/06/98 \\
\hline & O\&M & total & 0,00 & $\mathrm{U} \$ / \mathrm{tNH}_{3}$ & \\
\hline & O\&M & total2 & 0,00 & U\$ ano & \\
\hline & taxa de desconto & & 15 & $\%$ & \\
\hline$\overline{\mathrm{CCV}}$ & valor $\mathrm{F} / \mathrm{P}$ & 0,247184706 & & & \\
\hline & Inves.inicial & 1.295 .681 .06 & & & \\
\hline & vida útil equip. & 10 & & & \\
\hline & Invest. inicial & 1.295 .681 .06 & & & \\
\hline & $O \& M$ & 0.00 & & & \\
\hline & $\mathrm{CCV}$ & 1.295 .681 .06 & & & \\
\hline & FRC & 0,199252063 & & & \\
\hline & CCVA & 258.167 .12 & U\$/ano & & \\
\hline & ENERGIA ECONON & MIZADA & & & \\
\hline & $\begin{array}{r}0,70 \\
\end{array}$ & GJ/t NH & & & \\
\hline & 120120 & GJ/ano & & & \\
\hline & 2,15 & U\$/GJ economizado & & & \\
\hline
\end{tabular}

custo da instalação do recuperador de gás de purga, membranas

unidade de Piaçaguera =

$171600+\mathrm{NH}_{3}$ ano

\begin{tabular}{|c|c|c|c|c|c|}
\hline & & período de análise & \multicolumn{2}{|c|}{\begin{tabular}{r|r|}
10 & anos \\
\end{tabular}} & \multirow{3}{*}{$\begin{array}{l}\text { conversão DEM p/ US\$ } \\
\text { divide por } \quad 1,806\end{array}$} \\
\hline & Invest. inicial & recuperador gás de purga & $2.340 .000,00$ & $\overline{D E M}$ & \\
\hline & & recuperador gás de purga & $1.295 .681,06$ & US\$ & \\
\hline & & recuperador gás de purga & 7,55 & $\mathrm{U} \$ \mathrm{t} \mathrm{NH}_{3}$ & cotação OESP 13/06/98 \\
\hline & $O \& M$ & total & 0,00 & $\mathrm{U} \$ / \mathrm{NH}_{3}$ & \\
\hline & $\overline{O \& M}$ & total2 & 0,00 & US ano & \\
\hline & taxa de desconto & & 12 & $\%$ & \\
\hline $\mathrm{ccV}$ & valor F/P & 0,321973237 & & & \\
\hline & Inves inicial & $1.295 .681,06$ & & & \\
\hline & vida útil equip. & 10 & & & \\
\hline & Invest. inicial & $1.295 .681,06$ & & & \\
\hline & O\&M & 0.00 & & & \\
\hline & CCV & 1.295 .681 .06 & & & \\
\hline & FRC & 0,176984164 & & & \\
\hline & CCVA & $229.315,03$ & U\$/ano & & \\
\hline & ENERGIA ECONO & MIZADA & & & \\
\hline & 0,70 & GJ/t NH & & & \\
\hline & 120120 & GJ/ano & & & \\
\hline & 1,91 & U\$/GJ economizado & & & \\
\hline
\end{tabular}

custo da instalação do recuperador de gás de purga, membranas

unidade de Piaçaguera $=$

$171600 \mathrm{t} \mathrm{NH}_{3}$ ano

\begin{tabular}{|c|c|c|c|c|c|}
\hline & & período de análise & & anos & conversão DEM p/ US\$ \\
\hline & \multirow[t]{3}{*}{ Invest. inicial } & \multirow{2}{*}{\begin{tabular}{|l|} 
recuperador gás de purga \\
recuperador gás de purga
\end{tabular}} & $2.340 .000,00$ & DEM & \multirow{14}{*}{$\begin{array}{l}\text { divide por } \quad 1,806 \\
\text { cotaçăo OESP } \\
13 / 06 / 98\end{array}$} \\
\hline & & & $1.295 .681,06$ & US\$ & \\
\hline & & recuperador gás de purga & 7,55 & $\mathrm{U} / \mathrm{t} \mathrm{NH}_{3}$ & \\
\hline & O\&M & total & 0,00 & $\mathrm{U} \$ \mathrm{t} / \mathrm{NH}_{3}$ & \\
\hline & O\&M & total2 & 0,00 & U\$ ano & \\
\hline & taxa de desconto & & \multicolumn{2}{|c|}{$10 \mid \%$} & \\
\hline \multirow[t]{2}{*}{$\mathrm{CCV}$} & valor F/P & 0,385543289 & \multirow{8}{*}{\multicolumn{2}{|c|}{ U\$/ano }} & \\
\hline & Inves.inicial & $1.295 .681,06$ & & & \\
\hline & vida útil equip. & 10 & & & \\
\hline & Invest. inicial & $1.295 .681,06$ & & & \\
\hline & O\&M & 0.00 & & & \\
\hline & $\mathrm{CCV}$ & $1.295 .681,06$ & & & \\
\hline & FRC & 0,162745395 & & & \\
\hline & CCVA & $210.866,13$ & & & \\
\hline & \multicolumn{2}{|c|}{ ENERGIA ECONOMIZADA } & & \\
\hline & 0,70 & $\mathrm{GJ} / \mathrm{t} \mathrm{NH}_{3}$ & & & \\
\hline & 120120 & GJ/ano & & & \\
\hline & 1,76 & US/GJ economizado & & & \\
\hline
\end{tabular}


custo da instalação do pré aquecimento do gás de combustão

\begin{tabular}{|c|c|c|c|c|c|}
\hline & \multirow[b]{2}{*}{ Invest. inicial } & vida útil equip. & 20 & anos & \multirow{3}{*}{$\begin{array}{l}\text { conversão DEM p/ US } \$ \\
\text { divide por } \quad 1,806\end{array}$} \\
\hline & & pré aquecimento & $5.720 .000,00$ & DEM & \\
\hline & & pré aquecimento & 3.167 .220 .38 & US\$ & \\
\hline & & pré aquecimento & 9,60 & $\mathrm{U} \$ / \mathrm{NH}_{3}$ & \multirow[t]{4}{*}{ cotação OESP 13i06/98 } \\
\hline & O\&M & total & 0,00 & $\mathrm{U} \$ / \mathrm{t} \mathrm{NH}_{3}$ & \\
\hline & O\&M & total2 & 0,00 & U\$ ano & \\
\hline & taxa de desconto & & \multicolumn{2}{|c|}{$15 \%$} & \\
\hline $\mathrm{CCV}$ & valor F/P & 0,061100279 & \multirow{12}{*}{\multicolumn{2}{|c|}{ U\$/ano }} & \\
\hline & Inves.inicial & 3.167 .220 .38 & & & \\
\hline & vida útil equip. & 20 & & & \\
\hline & Invest. inicial & 3.167 .220 .38 & & & \\
\hline & O\&M & 0,00 & & & \\
\hline & $\mathrm{CCV}$ & $3.167 .220,38$ & & & \\
\hline & FRC & 0,15976147 & & & \\
\hline & CCVA & $505.999,78$ & & & \\
\hline \multicolumn{3}{|c|}{ ENERGIA ECONOMIZADA } & & & \\
\hline & $\begin{array}{r}0,80 \\
\end{array}$ & $\mathrm{GJ} / \mathrm{t} \mathrm{NH}_{3}$ & & & \\
\hline & 264000 & \multirow{2}{*}{\begin{tabular}{|l} 
GJ/ano \\
U\$ $/ G J$ economizado
\end{tabular}} & & & \\
\hline & 1,92 & & & & \\
\hline
\end{tabular}

custo da instalaçāo do pré aquecimento do gás de combustão

unidade de Camaçari $=$

$330000 \mathrm{t} \mathrm{NH}_{3}$ ano

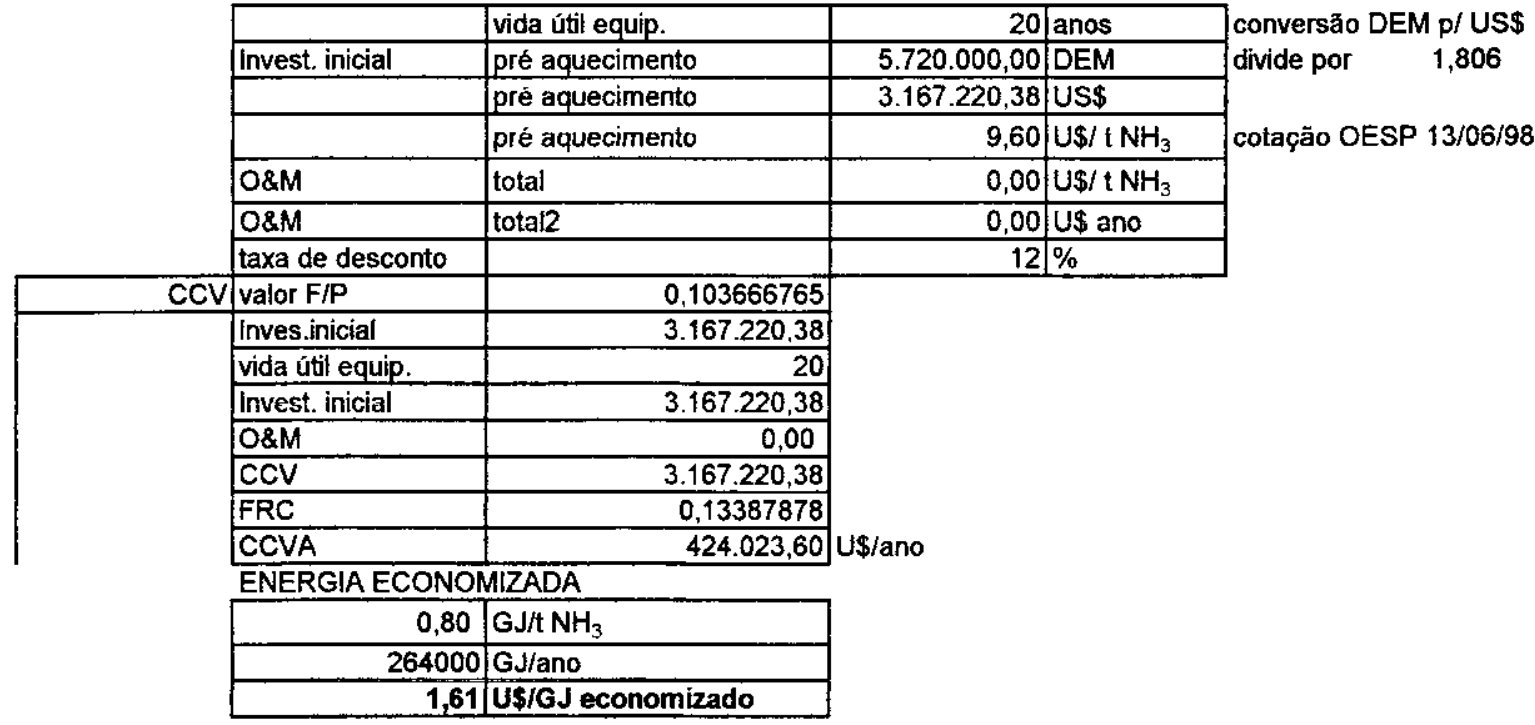

custo da instalação do pré aquecimento do gás de combustăo

unidade de Camaçari $=$

$330000 \mathrm{t} \mathrm{NH}_{3}$ ano

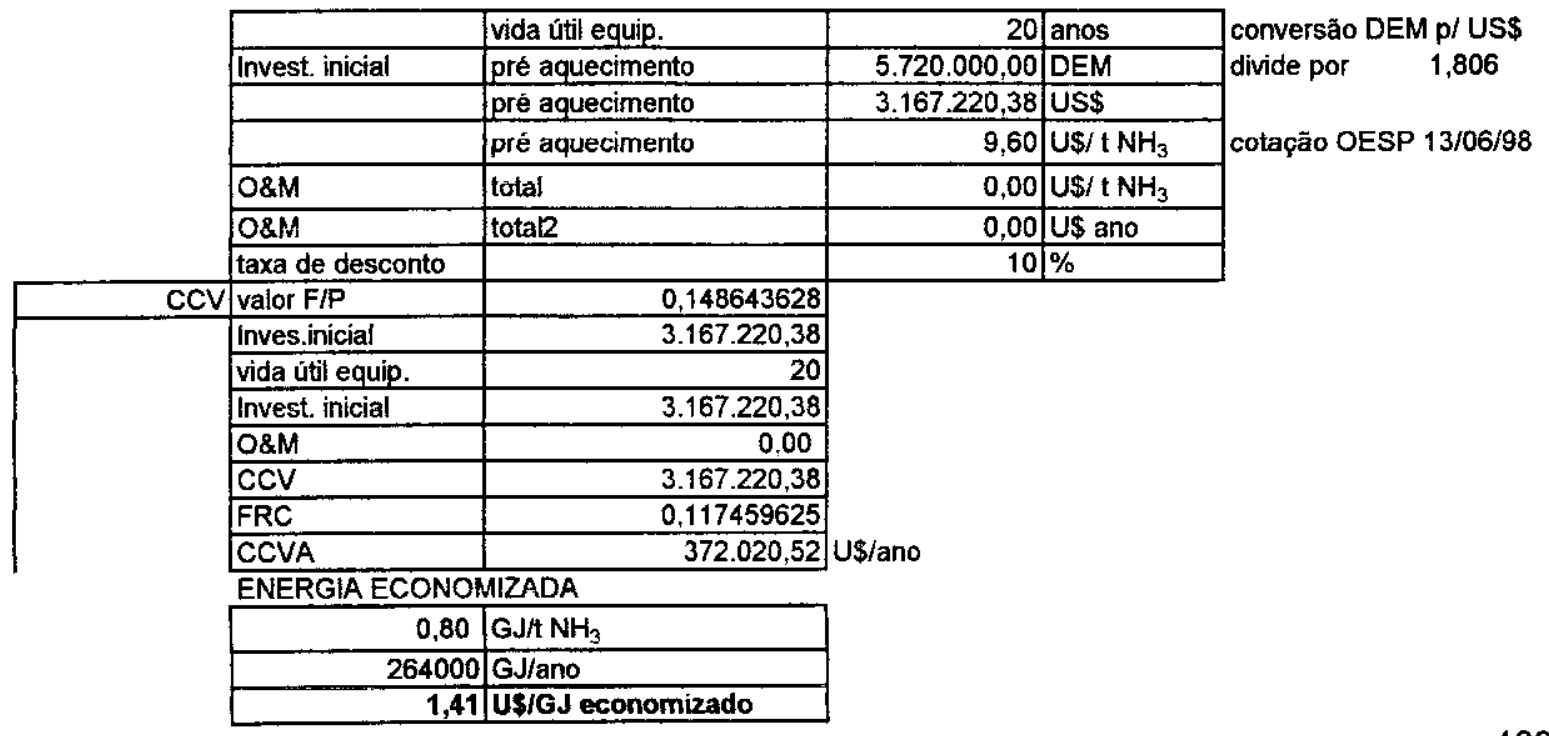


ANEXO - 4 


\title{
Integrated energy planning: Part I. The DEFENDUS methodology
}

\author{
Amulya K.N. Reddy, Antonette D'Sa and Gladys D. Sumithra \\ International Energy Initiative, 25/5 Borebank Road, Benson Town, Bangalore-560 046, India \\ P. Balachandra \\ Department of Management Studies, Indian Institute of Science, Bangalore-560 012, India
}

The process of energy planning involves the estimation of future energy demand and the identification of a mix of appropriate sources to meet this demand. This mix must emerge from a rational procedure in which various energy generation and/or saving options are evaluated. A powerful, simple and transparent approach to energy planning - the development-focused end-use-oriented service-directed (DEFENDUS) approach - is discussed here. Demand for a source of energy is based on the services for which it is required - the extent to which such services are spread among the population and the efficiency with which they can be delivered. The energy requirement so estimated is then matched with energy-supply and/or energy-saving options, so as to minimize costs. Starting with the reference energy system (RES) - the energy system as it obtains in the present (or the most recent past for which data is available) - the DEFENDUS approach constructs sce. narios of future energy demand, paying deliberate attention to the equity and energy-efficiency considerations of alternative scenarios. The costs per unit of energy supplied/saved are then estimated, including both investment and operating expenses as well as the costs of delivery to the consumer and the losses in distribution. Environmental impacts - and the cost of mitigating them - can be taken into consideration in the methodology. The economic impacts of a chosen scenario can also be included. By ranking the energy supply/saving technologies in increasing order of costs, the least-cost mix is obtained. Whereas with most pre-programmed packages, the planner must accept the format already provided, the DEFENDUS approach suggested here enables one to validate every step of the computation procedure and modify assumptions according to the actual case being considered.

The first part of the paper deals with the methodology proper. It refers to the reasons for developing such an energy-planning method, sketches a conceptual framework and then discusses the actual procedure in detail, including the usage and advantages of spreadsheets for computation. Part II (to be published in the following issue) will elaborate on examples of DEFENDUS scenarios.

\section{Introduction}

\subsection{Energy planning}

Energy is required to perform the tasks (such as lighting, cooking, and heating) through which consumers obtain the services (illumination, cooked food, and heat) they want. The amount of energy needed by each consumer varies with the level of services desired and the efficiency with which these services can be achieved. The aggregation of individual requirements in a given region leads to sectoral demand and hence to the total energy demand of the region. This energy demand must then be matched by a supply of energy. Often, this supply is from a mix of various sources.

The fundamental premise underlying this study is that the mix must emerge from a rational procedure in which choices are made from alternative options of energy generation and/or energy saving. The energy-saving options (through improvements in the efficiency of usage) have to be considered because by obviating the need for gen- eration to the extent of the energy saved, they are effectively equivalent to supply. Energy planning consists of estimating future energy requirements and identifying the appropriate "supply" technologies to satisfy these requirements.

Since energy plays such a central role in satisfying human needs and advancing development, energy planning is obviously a crucial activity which deserves prime importance. The purpose of this paper is to discuss a simple, transparent and powerful approach to energy planning.

1.2. Existing energy-modelling software

There are a number of software packages that can be run on personal computers (PCs) to make forecasts in the energy sector - LEAP (Long-range Energy Alternatives Planning) [LEAP, 1990], MEDEE-S (Modèle de demande en énergie pour les pays du Sud) [MEDEE-S, 1995], and BEEAM-TEESE (Brookhaven Energy Economy Assessment Model-TERI Energy Economy Simulation and Evaluation) [Pachauri and Srivastava, 1988], and others. 
These "ready-made" software packages are based on models of the energy system. They provide scope for relating energy demand directly to the end-uses of energy at the device and service levels. They also include macroeconomic parameters by which the impact of structural changes in the economy can be monitored. The linkages between the various programs of a package ensure that changes in one sector are transmitted to other relevant sectors. Further, very detailed analyses can be carried out. For instance, in the LEAP package, an alteration in the energy consumption of a device can be tracked from the unit-usage of the device in each sub-sector, to the total demand, which in turn is translated to the primary resource requirements and consequently to a relative change in costs. The models also permit various technological options and choices of fuel-mix in end-use activities.

Hence, these energy-planning packages afford a comprehensive analysis of the energy sector, as well as its relationship with the rest of the economy. Obviously, the usual advantages of computers over manual calculations (even with hand-calculators) are obtained - computers perform tasks much faster and more accurately and also eliminate the tedium of repetitive calculation, freeing the analyst for more productive work.

A study of five software packages - Energy Toolbox, ENPEP [Buehring et al., 1991], MESAP [Reuder, 1990], LEAP and MEDEE-S has been carried out [Enerdata S.A., 1993] to choose an energy demand projection model for African countries. The study has highlighted three main issues. Almost all African countries have an energy demand model at their disposal (thanks invariably to a project based on a foreign consultant), but the model is not used in energy planning after the consultant has left. Because of the similarities between the various African countries, there should be a common methodology, but the approach must have the flexibility to cope with the diversities as well. The model must be of the end-use type.

There are, however, disadvantages with pre-programmed packages. Firstly, the formulae employed in the programs are entered at the stage of software programming, so that the user has little or no control over the actual computational procedure. As such, the energy-planner is forced to accept the general-case treatment instead of evolving a method that could be more appropriate for the particular case under consideration.

Secondly, as users are generally not equipped with the source-codes, they remain dependent on the programmers of the package for any alterations. Moreover, in cases where the formulae are not clearly specified in the usermanual, they have first to be derived by the user or else the estimation procedure remains opaque. Because of this, it is also difficult to locate errors.

Thirdly, the form in which data has to be entered may not coincide with that in which information is available, so that a certain amount of exogenous data-processing has to be completed before the package can be used. Fourthily, some packages impose major constraints on the planning process, for example, constant energy efficiencies throughout the planning period.

There are also a number of energy-system models implemented on mainframes, such as MARKAL [Goldstein, $1990]^{[1]}$ (and its regional version MENSA) and BE$S \mathrm{M}^{[2]}$ - both linear programming models, the Argonne Energy Model ${ }^{[3]}$ (a network model) and many others that have been used in various countries [Meier, 1985]. These facilitate much more elaborate calculations than the PCbased systems, but they suffer even more from the "blackbox" syndrome. Since the models are large and complex, the fundamental relationships between the variables and the data parameters are often taken as "given" and the users are not able to validate these equations in relation to the region being studied, unless there is continuing software support. Large-system packages are also less accessible because of their cost.

\subsection{The origin of the DEFENDUS methodology}

In the context described above, it is essential to evolve a simple method of computing energy demand and supply in which the planner has complete control over the entire procedure. Also, the steps followed must be "transparent" enough to be easily understood and amenable to easy modification by another planner. Finally, those who wish to replicate computations must be able to use the first computation as a model and "default case" and therefore avoid "re-inventing the wheel". All these objectives were achieved by the DEvelopment-Focused END-Use-oriented Service-directed (DEFENDUS) methodology for estimating the demand and supply of energy in an energy system.

The DEFENDUS methodology was evolved for a number of immediate reasons. When analysing the projections of Kannataka's ${ }^{[4]}$ electricity demand obtained from various planning exercises [Pachauri et al., 1980; PPD-GOK. 1981; WG-GOK, 1982; GOK, 1982; PWED-GOK, 1983; CEA, 1985; CPRI, 1987; LRPPP, 1987; CEA, 1987: PDGOK, 1989], it was found that the estimation of future requirements of electrical energy is conventionally carried out via projections of demand, that is, via extrapolation of current demand at the rate of growth characteristic of the immediate past. These business-as-usual projections generally exclude the possibilities of improvements of energy efficiencies and alterations of growth rates, so that the future is viewed as an amplified version of the recent past. However, an alternative scenario ${ }^{[5]}$ approach could be adopted where one would assume that just as present timansua electricity consumption are the oustertere of past policies, new outcomes can be chosen and a specification made of what policies can bring them about.

Secondly, the DEFENDUS team had undertaken a project $^{[6]}$ that required the evaluation of an energy-planning software package in the context of developing countries. It was decided to apply the software to the state of Karnataka and construct energy demand and supply projections for the electricity system. Since the results could not be audited step-by-step with a calculator, it was considered important to veriff the results obtained from the software package. It was also felt that the best verification 
would consist of developing an alternative methodology and using it for the same problem of electricity in Karnataka.

Thirdly, the perspective in the book Energy for a Sustainable World [Goldemberg et al., 1988] included energy conservation measures (the use of more energy-efficient processes and devices) and the use of new renewable sources of energy. But such technologies can be brought into actual usage only if the magnitude of energy conservation/generation and the cost involved warrant them. This necessitated the quantification of energy saving and generation possibilities and the calculation of the cost per unit in each case, in order to formulate economically viable plans. Once again a simple model that evaluates alternative scenarios was required.

All these considerations led to the formulation of a DEFENDUS approach to energy planning that was used initially for electricity [Reddy et al., 1991] in the state of Karnataka but had the potential for replicability, i.e., it could be used for other energy sources/carriers and other geographical regions.

1.4. Application has received more attention than methodology

Since the DEFENDUS electricity scenario was developed in response to a projection for Karnataka made by a Government-appointed Committee for the Long Range Planning of Power Projects (LRPPP), the focus in the DEFENDUS publication [Reddy et al., 1991] was on the application of the methodology to the electricity system of Karnataka. There were a number of reactions [Parikh, 1991; Shah, 1991; Banerjee, 1991] to the work, but these also focused on the Karnataka electricity scenario and its "implementability" rather than on the methodology that had been used. For instance, doubts were expressed regarding the practicality of reducing electricity demand through efficiency improvement. Questions were also raised about the validity of using the Karnataka assumptions for other states in India.

Discussion then shifted to the possibility of using the DEFENDUS methodology for energy planning in other developing countries. ${ }^{[7]}$ Questions such as the following have been asked.

- Can the methodology initially developed for electricity be used for other energy sources/carriers?

- Can one go from electricity planning to energy planning involving the integration of a number of energy sources/carriers?

intumetaden

- Can the macroeconomic implications of the PEFENDUS scenarios be spelt out? explicitacton/wrium

- Does the methodology permit an estimate of the environmental impacts of the scenarios?

Though the answers to many of these questions are implicit in the original Karnataka Electricity Scenario paper, it is clear, in retrospect. that the original presentation buried the methodology in the application. This paper is addressed therefore to an $a b$ initio exposition of the DEFENDUS methodology per se.

\section{A conceptual framework for energy planning}

\section{I. A systems view of energy planning}

A system can be defined as the portion of the universe that is chosen for consideration. Every system is a subsystem of a larger system that constitutes its environment and with which it is in interaction. At the same time, every system has a structure, i.e., it is itself an organization' of parts (sub-sub-systems) in interaction.

The energy system is a sub-system of the economy, which, depending upon the level of analysis, may be the economy of the world, a country, a state within the country, a city or village, or even a firm or farm.

$T$ In order to take a systems view of energy planning, it is necessary to treat the energy sub-system, the economic system (of which the energy sub-system is a part) and the activity of planning. Systems involving human beings are goal-oriented, and the purpose of energy planning is to make the energy sub-system drive the goal-oriented system towards its goal(s). Every goal implies choices, valves and preferences, and therefore a goal-oriented approach is a normative approach that defines what is desirable.

Whenever questions of pianning are raised (whether at the level of the country, state, corporate entity or firm), the words: goals, strategies, policies, policy agents and policy instruments are invoked. Hence, it is worthwhile adopting clear-cut definitions of these terms. A goal is an objective that the system should attain. A strategy is a broad plan to reach that goal. A policy is a specific course of action to implement the strategy. A policy instrument is an instrument with which policy is initiated and maintained. A policy agent is one who wields a policy instrument.

It may be noted that goals, strategies and policies constitute different levels of hierarchy in the scheme of concepts, the degree of specificity, the flow of interconnections and the set of actions.

- For goals to be attained, strategies must be implemented, for strategies to be implemented, policies must be given effect to and operated, for policies to be given effect to and operated, policy instruments must be initiated and maintained, and in addition, policy agents must employ policy instruments. ${ }^{[8]}$ Thus, goals, strategies, policies, policy instruments, and policy agents are all interrelated. This interrelationship can be brought out through a systems diagram (Figure 1) which reveals two important features:

1. the feedback loop that emphasises the iterative character of the process, whereby energy planning and implementation make the energy sub-system drive the goal-seeking system towards its goal(s); and

2. the components of energy planning, which include goals, strategies, policies, policy instruments and pol-

icy agents, implementation, monitoring, and analysis. This model can be considered to be applicable at all system levels - the world, a country, a state within a country, a city or village, a farm or firm. 


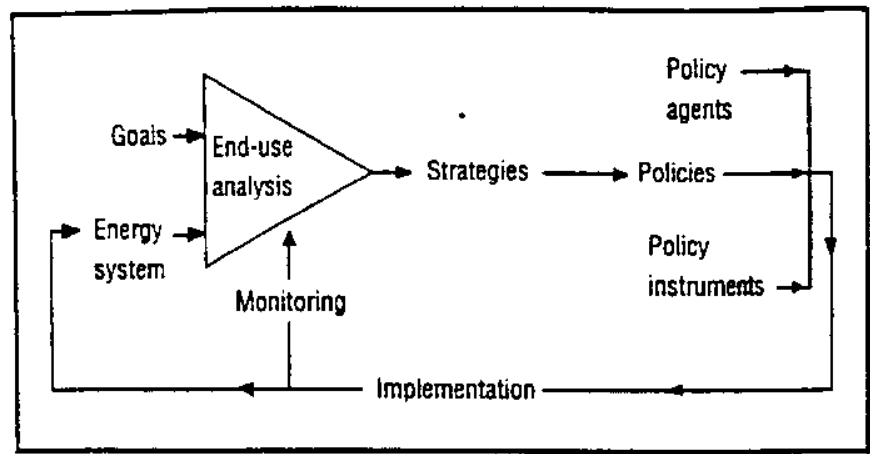

Fig. 1. From goais to policy implementation - the feedbact.

\begin{tabular}{|c|c|c|c|c|}
\hline $\begin{array}{c}1 \\
\text { Energy } \\
\text { sources }\end{array}-$ & $\begin{array}{c}2 \\
\text { Primary } \\
\text { energy }\end{array}$ & $\begin{array}{c}3 \\
: \text { acilities/ } \\
\text { utilities }\end{array}$ & $-\begin{array}{c}4 \\
\text { energy }\end{array}$ & \\
\hline $\begin{array}{c}5 \\
\text { Transmission } \\
\text { distribution system }\end{array}$ & ${ }_{\text {energy }} \begin{array}{c}6 \\
\text { Final }\end{array}$ & $\begin{array}{c}7 \\
\text { End-use } \\
\text { devices }\end{array}$ & $\begin{array}{c}8 \\
\text { Useful } \\
\text { energy }\end{array}$ & $\begin{array}{c}9 \\
\text { Energy } \\
\text { services }\end{array}$ \\
\hline
\end{tabular}

Fig. 2. The reference energy system.

\subsection{Reference energy system (RES)}

The starting point of energy planning activity at any system level has to be the structure of the energy system. This structure involving the parts of the energy system and their interactions is best represented by the reference energy system (RES), i.e., the energy system as it obtains at present or as it obtained in an immediate past for which data is available. The RES must inciude all the energy sources of nature that are exploited, all the intermediate forms or carriers into which these sources are transformed to enhance the convenience with which they are utilized, the sub-systems for transmission/transportation and distribution of these energy carriers, and the end-use devices that are used to obtain the services that energy provides - cooking, lighting, water, process and space heating, mobility, shaft power, and information flow. Further, the RES must span both the qualitative and quantitative descriptions of the energy system.

The RES can have several possible structures in the sense that there are many equally valid ways in which the RES can be displayed. One possible structure results from the fuel-cycle approach - the RES can be structured to follow the flow of energy from sources to services. Such an approach would start from the primary energy provided by the sources as found in nature, then consider in sequence the secondary energy at the output of the facilities which convert the primary energy into carriers that are readily and conveniently usable by consumers, the final energy as received (after transmission/transport and distribution) by the consumers, and the useful energy at the output of the consumer's end-use device, i.e., energy conversion system, which provides the energy service sought by the consumer.

Power plants, oil refineries and coal gasification plants are examples of facilities/utilities that convert primary into secondary energy. The high-voitage grid, gas pipelines, and petroleum transport, storage and distribution facilities are examples of the energy transmission/transport and distribution sub-system. Stoves, furnaces, kilns, lightbulbs, engines and motors are examples of end-use devices.

Further, at every one of these stages of energy conversion, there inevitably are energy losses. In the transformation from primary energy into secondary-energy carriers, there are conversion losses at the facilities/utilities. Similarly, in delivering the energy carriers as final energy to the ultimate consumers, there are transmission/transport, storage, and distribution losses. Finally, when the consumers convert the final into useful energy, there are losses in the end-use devices.

It appears that a simple and logical way of representing the RES is in terms of a nine-column structure (Figure 2).

Unfortunately, it is extremely difficult, if not virtually impossible, to find energy data in a form which can be incorporated directly into this structure.

In the first place, it is much easier to get information on primary and secondary energy, particularly for the conventional commercial sources of energy, than on final and useful energy. That is, there is far more data on the supply aspects of the energy system than on the demand aspects.

Secondly, the available demand data is usually in a highly aggregated form. For example, energy consumption data invariably pertains to a few important sectors - industry, agricuiture, transport, domestic, and commercial rather than to types of services, consumers, and end-use devices. (Incidentally, this biased character of the database for energy represents the rapidly vanishing era when the bridging of the energy supply-demand gap could be achieved exclusively by augmenting energy supplies and without exploring the possibilities of demand management.)

To develop an RES structure that would be appropriate for the available energy data, it may be necessary to alter the specified columns. The resulting RES structure would permit the use of sectoral energy consumption data which cannot be further sub-divided at this stage of the study into consumption by consumers and by end-use devices. Where the data is available in a less aggregative form, it can be collated into sector-wise categories. The structure would also allow the energy carrier data to be seen alongside the sectoral consumption for conventional discussions.

\subsection{Energy futures}

2.3.1. Prediction, forecast, projection, scenario, target and goal

Energy planning necessarily involves goals, and goals require discussion about the future. This involves various words related to the certainty, freedom of choice, degree of detail and the sharpness of focus of that future. In particular, six words are commoniy used: prediction, forecast, projection, scenario, target and goal. Appendix 1 provides working definitions for these words so that there is no ambiguity.

\subsubsection{Reference energy system to energy planning}

The first step in energy planning is to choose a time horizon for the planning exercise. The energy plan must then 
describe the evolution of the reference energy system from the base year up to the horizon year. That is, the dynamic changes in the energy system must be considered. For the horizon year, therefore, both the demand side of the energy system and the supply side must be elaborated.

Thus, an energy future consists of two parts - future energy demand and future energy supply to meet that demand.

Two crucial questions arise.

1. How is future demand to be arrived at, given the present energy demand from the reference energy system?

2. How are future supplies to be ensured over and above the supplies described by the reference energy system? On the demand side, the focus should ideally be on the useful energy that decides the energy services enjoyed by consumers, but in practice, attention is usually restricted to final energy. On the supply side, attention is restricted either to the primary energy or, in the case of electricity and petroleum derivatives, to secondary energy.

\section{Basic components of the DEFENDUS methodology}

The DEFENDUS methodology has two main components: 1. a methodology for the construction of DEFENDUS (development-focused end-use-oriented service-directed) demand scenarios for an energy carrier/source, in which deliberate attention can be paid both to the equity (distributional) and the energy-efficiency dimensions of energy scenarios; and

2. a methodology for the determination of a least-cost supply mix (of saving, decentralized generation and centralized generation options) to meet future energy requirements.

\section{I. Construction of DEFENDUS demand scenarios}

With regard to the prediction/forecast/projection/scenario of future demand, there are at least five conventional approaches:

1. the trend method,

2. the growth rate method,

3. the econometric ${ }^{[9]}$ method,

4. the techno-economic method, and

5. the input-output method.

However, these approaches are well-known and are therefore not elaborated upon here.

In contrast, the DEFENDUS methodology makes use of the scenario approach which - as pointed out above is based on a set of energy measures that would transform the present into the future. Thus, scenarios are quite different from projections that relate the future to the present with the aid of mathematical relations. Scenarios are actually exercises that answer the question: "If measures $\mathrm{M}_{1}, \mathrm{M}_{2}, \mathrm{M}_{3}, \ldots$, are implemented, what will the result be?"

The particular measures that provide the basis for the scenarios have to be derived from the goals and strategies for the energy system prescribed by the scenario-builder as part of a normative exercise (Figure 3 ). Hence, scenar-

\section{Goal (s) $\longrightarrow$ Strategy $\longrightarrow \Sigma$ Measures $\longrightarrow$ Demand scenario}

ios cannot be constructed without specification of measures; measures must follow from strategies; and strategies have to be derived from goals.

Initially, the emphasis has to be on scenarios for specific energy sources/carriers - electricity, coal, petroleum deriyatives, biomass, etc. These source/carrier-specific scenarios can then be linked together, as described later.

As the term DEFENDUS suggests, there are two important aspects to be considered when constructing a scenario for the future demand of an energy source/carrier the development focus and the end-use orientation.

The development focus presumes a view on development, but the methodology does not in any way constrain this view. If, for instance, development is considered to be a process of economic growth directed towards (1) the satisfaction of basic needs, starting from the needs of the neediest, (2) a strengthening of self-reliance, and (3) harmony with the environment, then the development focus must reflect a determination to reduce poverty and inequality, and to increase self-reliance in an environmentally sound way. Such a focus would determine the rates of growth of particular sectors (or categories of consumers) in an economy; for instance, one of the requirements for need-oriented development of a region could be the provision of electric lighting in every home, which would necessitate an enhanced rate of growth of electricity connections in the domestic category.

If, however, development is simpiy equated with economic growth measured by the GDP, irrespective of the distribution of its benefits, then current growth rates of various categories of consumers can be made to persist throughout the scenario.

The end-use orientation concentrates on the end-uses of energy and the services to be derived from energy, rather than the quantity of energy used. What is pertinent is the attainment of a certain amount of heating, lighting or motive power, and not necessarily an increased energy usage, because technological improvements can lower the need for energy while retaining the same level of energyderived services. Thus, the end-use orientation is based on an understanding of the technological opportunities in the utilization of energy. In this case too, the DEFENDUS methodology does not constrain the planner to pursue an efficient future - present (in)efficiencies can be made to prevail.

The development focus and end-use factors imply that in order to estimate the requirement of a particular source/carrier of energy, one must take into account:

- the number of energy users (or energy-using entities, such as pieces of equipment or devices) of that source of energy; and

- the average amount of energy required per user per period, i.e., the existing energy consumption "norm" 


\section{of that user.}

The total energy demand is then equal to the aggregate demand of all the categories of users (or types of energyusing devices) for every end-use. The mathematical representation of this approach to energy demand is given in Appendix 2.

The estimation of demand for a particular energy source/carrier in a particular year is therefore dependent on two variables - the number of users and their actual energy requirement in any base year, as well as the expected (or policy-driven) changes in these two variables in subsequent years. On the basis of this relationship, one can calculate any variant of the general case.

For instance, by maintaining the status quo in the average energy usage and the current trend of growth of users, one can develop a business-as-usual scenario.

Another alternative would be to alter only the growth rates of the number of users, keeping the energy usage constant. This frozen-efficiency scenario would assume that although the number of users changes, the level of energy usage per user remains constant as the technical efficiencies of energy-using processes/devices are "frozen" at the base-year level and no substitution between energy carriers takes place. ${ }^{[10]}$

The other type of scenario would involve changes in both the category-wise growth rates of users (for development or equity reasons) as well as the energy usage of these consumers (possibly with efficiency improvements and carrier substitution).

\subsection{Comparative costing}

Once the total energy demand has been estimated, the question of how this demand should be met must be addressed.

The sources of energy available to a region may be of different types - whether from large-scale centralized plants (such as petroleum refineries, coal-mines, and thermal and hydro-electricity generating plants, etc.) or smallscale decentralized (local) plants. Further, conservation of energy (through the improved efficiency of processes and devices) can also be considered as an option for meeting the energy needs, in so far as the demand for a certain amount of energy is reduced and supply can therefore be avoided or diverted to other uses.

A choice between different options - generation and conservation - must depend, in the first instance, on their comparative costs. However, while computing the costs per unit of energy from various technologies, it has been found [Reddy et al., 1990] that great care must be taken to ensure that the comparison occurs on equal terms. In particular, the following requirements must be ensured.

- All the costs - fixed or variable - should be expressed with respect to a particular (reference) year, so that a doliar of one year is not equated with that of another.

- Discounted cash flow techniques must be used to take into account the time value of money. Thus, although the cash flows of the plants would differ, the comparison would be made between the present value (PV) ${ }^{[11]}$ at the same reference date of each stream of flows.
- The same discount factor must be used for all the calculations; further, either nominal or real discount rates should be used, but not both.

- The gestation period (the time-lag between the commencement of construction of the plant and its commissioning) varies greatly between technologies. This must be taken into account in one of two ways. Either the value of the physical output (energy generated/saved) must be discounted from the different commissioning dates to the commencement date at which point comparison can be made. Or, the costs must be appropriately inflated to compensate for the time lags between the commencement of construction and the commissioning of each plant. This is economically justifiable, as the longer the gestation period, the greater will be the imputed cost per unit of energy; conversely, the sooner the returns can be obtained, the lower the imputed cost.

- When comparing centralised technologies (which have to transmit energy over long distances to the end-use devices of consumers) with decentralised (local) technologies, the storage, transmission, and distribution losses should be taken into account so that the actual energy delivered is quantified. Then, the comparison can be made at the consumption end - but it is not permissible to take one technology at the generation end and the other at the consumption end. Further, the additional costs of delivering energy via the grid (setting up transmission and distribution facilities) should be added to the costs of generation.

Once the cost per unit of energy generated/saved from each technology has been calculated with the above precautions, a comparison of technologies on equal terms is possible and available. One can even rank technological options on purely economic terms. All this is essential to facilitate the task of determining a least-cost mix of generation/saving technologies.

\subsection{Least-cost supply mix}

The purpose of selecting a "least-cost" mix of energysupply options is to attain the energy-demand goal at the minimum cost. In terms of a linear programming (LP) problem, the objective function would be the total cost of the supply of energy and one would have to minimize this, subject to the constraints that the total energy obtainable would be at least as much as the forecast requirement and that the contribution that each technology can make towards meeting the demand does not exceed its viable potential. The LP formulation would be:

Minimize $Z=\Sigma C_{i} \cdot E_{i}$, subject to:

$$
\begin{aligned}
& \sum E_{i} \geq E_{t} \\
& \text { and } \\
& E_{1} \leq P_{1} \\
& E_{2} \leq P_{2} \\
& \ldots \ldots \\
& \ldots \ldots \\
& E_{m} \leq P_{m}
\end{aligned}
$$

where each $C_{i}$ represents the cost per unit of the source of energy $E_{i}(i=1,2, \ldots, m), E_{t}$ is the total requirement 
of energy in the year $t$ for which plans are being made, and $P_{i}$ is the limit of the potential of the source pertaining to that region. This impiies that the total cost of energy supply (equivalent to the sum of the costs of the various sources) must be minimised, while meeting the total energy demand and simultaneously not exceeding the available potential of each source in the region.

An alternative to such an LP calculation is to construct a least-cost supply curve showing the cheapest mix of energy generation/saving options that will meet the energy requirement. In fact, it can be shown that this least-cost mix is automatically the mix that would be obtained from a solution to the $L P$ cost-minimization problem. To construct a least-cost supply curve, the technologies must be ranked in increasing order of the costs per unit of energy (or unit energy cost). Options must then be chosen in this order, ${ }^{[12]}$ adding the contribution of each towards the fulfilment of energy requirements. This procedure could be diagrammatically represented in the form of a staircase, on a grid where energy is measured on the horizontal axis and cost per unit of energy on the vertical axis (Figure 4). Then the width of each stair indicates the energy potential of a particular option and the height refers to its cost per unit of energy, so that the rectangle representing each step of the stairway corresponds to the total cost incurred on that option. One must consider the least expensive technology as the first element of the supply mix and, after the potential of that option is exhausted, the next costlier option (corresponding to the next higher step), and so on, up the cost-supply staircase until the energy goal is reached.

CIt must be observed that the same energy-efficiency improvement measures cannot be considered on both the demand and the supply sides; they can be counted only once. Hence, if efficiency measures are to be included as candidates among the supply options (in terms of supply avoided), then the estimation of the demand goal should obviously not include efficiency improvement, that is, a frozen-efficiency scenario must be used for the corresponding demand forecast.

The approach thus described does not favour any particular type of technology; an option will be chosen if and only if its unit cost and energy contribution find a place on the cost-supply staircase before the frozen-efficiency demand goal is reached.

A DEFENDUS scenario for an energy carrier/source is unaware of the spatial domain under its consideration whether it is a village, city, state, or country. On the demand side, it only considers the categories of consumers and their energy usage; on the supply side, it has the flexibility of considering imports. Thus, the validity of the DEFENDUS methodology is invariant with respect to the size and nature of the domain; it is either valid for all domains or for none.

\subsection{Environmental impacts}

The DEFENDUS methodology can capture the environmental impacts of the supply mix at two stages.

During the determination of the least-cost supply mix:

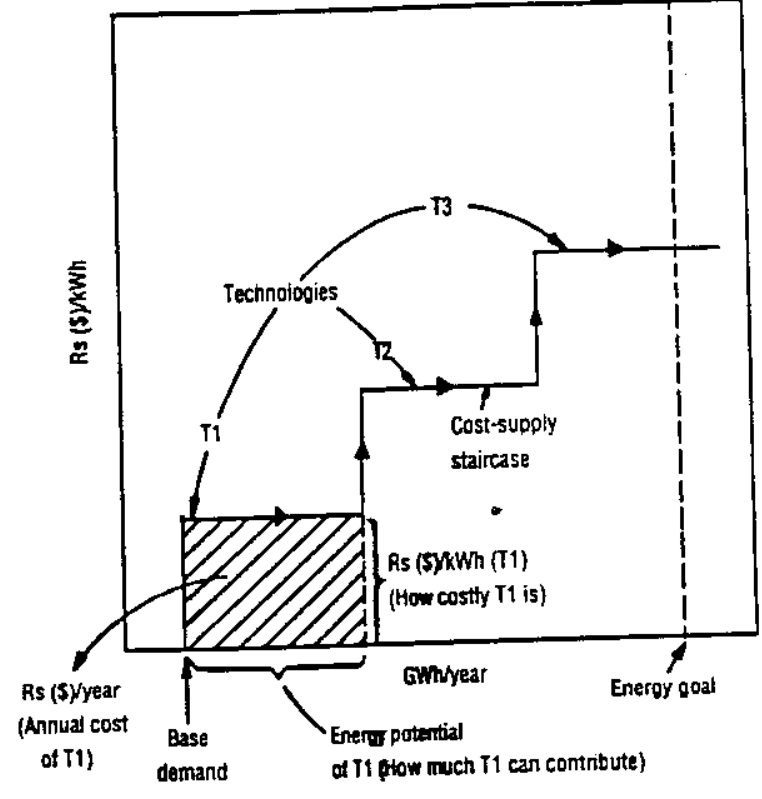

Fin. 4. Least-cost planning - coustruction of a cost-supply staircase.

This requires a consideration of the costs of the option with and without the costs of environmental protection. For instance, the cost of hydroelectric energy (or power) can be estimated with and without the costs of compensatory afforestation and rehabilitation of displaced persons; the DEFENDUS Electricity Scenario for Karnataka has done this for the costing of hydroelectricity. Like the costs of an energy technology, the costs of the environmental impact of that technology and the mitigation costs have to be analysed separately from the energy planning exercise, but once these costs are determined, they can be incorporated into the procedure for determining supply mixes.

After determining the least-cost supply mix: The environmental impacts per unit of energy saved/generated, for each option in the least-cost supply mix, can be estimated separately (for example, carbon emissions per $\mathrm{kWh}$ ) and compared with other supply mixes; this has also been done in the paper on the DEFENDUS Electricity Scenario for Karnataka.

Thus, the DEFENDUS methodology has the capacity to handle environmenial impacts and their mitigation costs once these are determined.

\subsection{Economic implications}

The area under the least-cost supply curve represents the annualized financial cost of that particular mix, and this cost can be compared with the corresponding cost for any other mix. (The DEFENDUS electricity scenario for Karnataka was compared with the costs of the LRPPP projection for Karnataka in this manner.) If the cost-supply curve were to be constructed with economic costs, ${ }^{[13]}$ then a comparison of economic costs would also be possible. Thus, financial and economic impacts are within the scope of the DEFENDUS methodology.

atimara

Though DEFENDUS scenarios have not hitherto elabo- 
rated on their macro-economic implications, there are simple approaches to assessing these impacts.

The empirical relationship between the production and the energy usage of a sector can be easily obtained. The regression of sectoral energy usage (for example, industrial electricity usage in a state) on the sectoral production (say, industrial contribution to state domestic product) yields an estimate of the energy-product coefficient. ${ }^{[14]}$ Substituting this coefficient and the estimated energy requirement in a DEFENDUS scenario for a particular year, in the same equation, one can obtain an estimate for sectoral output in that year. However, this will be a lower bound estimate of the sectoral product because it uses a constant product-energy coefficient obtained from past data along with an efficiency-induced (i.e., relatively low) future energy requirement.

If, instead of the DEFENDUS scenario energy estimate, the frozen-efficiency scenario estimate of energy requirement is used, along with the same energy-product coefficient, then the result will be an upper bound estimate of sectoral product. Efficiency improvements will put the estimate of sectoral production somewhere between these lower and upper bounds. However, as the energy-service levels achieved in both the DEFENDUS scenario (with efficiency improvement) and the frozen-efficiency scenario (without efficiency improvement) are the same, the sectoral product estimate corresponding to the latter can be considered for the former as well. Taking this estimate of production and the corresponding DEFENDUS scenario energy demand, one can calculate a new energyproduct coefficient. The difference between the two coefficients indicates the effect of efficiency improvement. Appendix 3 deals with this in greater detail.

\subsection{Spreadsheets for DEFENDUS scenarios}

Spreadsheets have been found to be very useful for the construction of DEFENDUS energy scenarios as they have certain inherent advantages for the computational procedure described above.

In actual practice, the spreadsheet is arranged so that the columns denote the various consumer or end-use device categories which comprise the usage of the particular energy source/carrier. With regard to the rows, an initial block is assigned to specify the characteristics of the energy usage in the base year. Thereafter, one block of rows is assigned for each year of the plan until the horizon year. Each of these blocks is used to carry out the estimation of the number of consumers/end-use devices in that category and their corresponding energy usage. The computation requires the growth in the total number of consumers or end-use devices, the fractions of old consumers/end-use devices that retain the previous year's average energy usage and those that have a different average energy usage. Thus, the spreadsheet is based on a year-by-year estimation advancing from the base year to the horizon year.

The advantages of constructing DEFENDUS scenarios using spreadsheets are many. Firstly, the energy planner has the freedom to specify the parameters and the formulae on the basis of which the values of the variables are calculated. Depending on the scenario envisaged, these can be easily modified. Thus, the energy planner has complete freedom to change at will (or not to change at all!) the growth rates of consumers/end-use devices and their average energy usage throughout the planning period. The structure also enables one to determine the pattern of implementation of efficiency improvements and new devices, for example, according to a logistic curve.

Secondly, within a spreadsheet, a formula applied to a particular cell can be easily replicated for the remaining cells of the row or column, so that the calculation for any category of consumers/suppliers can be used for other categories of consumers/suppliers. Further, formulae can be entered in terms of the cell addresses, instead of the absolute values of the variable - this links various sections of the spreadsheet, enabling one to estimate the sensitivity of results to changes in any particular value. Results of iterative calculation are obtained almost instantaneously.

Thirdly, it is convenient to utilise the framework already constructed for any new but analogous calcuiation. For instance, similar spreadsheets were used for the estimation of electricity demand in Karnataka and various other states, the requirement of biomass and of petroleum products in Karnataka and of petroleum products in India. Obviously, the actual sectors, categories of users, and other such parameters would determine the final framework of the spreadsheet. However, the method of analysing demand by type of consumer (or uses or devices) and quantifying each category of demand through the product of the number of consumers/uses/devices and their average energy requirement is applicable to different analyses.

Separate spreadsheets can also be linked to each other - a facility particularly necessary for any study of more than one sector and for linking the energy sector with the rest of the economy. 


\section{Appendix 1. Definitions of prediction, forecast, projection, scenario, target and goal}

A prediction is a prophesy that describes what will hapnen. a forecast states what is likely to happen, and a projection is an estimate of future trends. Thus, these three words constitute a hierarchy in which the degree of certainty increases as one goes from projection (estimate) to forecast (likelihood) to prediction (prophesy). When the question of how certain we are of the future arises, then one of these three words must be invoked.

There are two categories of projections, forecasts and predictions: the reference leve! or base-line versions that assume that there will be no interventions to alter present trends, i.e., the business-as-usual (BAU) category, and the intervention-based (IB) variety. The business-as-usual and intervention-based projections, forecasts and predictions involve starting from the present and working forwards to the future. But it is also possible to assume a future and work backwards - this is what is done in a scenario or imagined sequence of events that would transform the present into the future. Scenarios, business-as-usual extrapolations and intervention-based versions of the future all concem the question of how the future is chosen or designed.

The degree of choice and activeness of role increases as we ascend the hierarchy from business-as-usual extrapolations through intervention-based projections, forecasts and predictions to scenarios. On the other hand, the extent of destiny and passiveness of our roles increases as we descend from scenarios to business-as-usual extrapolations.

Finally, there is the question of the degree of detail and the sharpness of focus with which we see the future. When the image is sharp and there is a wealth of detail, we refer to a target or minimum result to be aimed at. In contrast, when there is only a broad picture without much detail and the focus is blurred and diffuse, we speak of a goal or broad objective.

Thus, the words prediction, forecast, projection, scenario, target and goal arise from attempts to answer the following three questions regarding the future.

1. How certain is the future?

2. How much choice is there with respect to the future?

3. How clear is the future?

\section{Appendix 2. Derivation of the mathematical expression for the estimation of future energy demand}

Consider the annual energy demand of a region in the year $t^{[15]}$ Let this total energy requirement be $E_{t}$. Then $E_{t}$ is the aggregate requirement of all $i$ energy sources or carriers in use (such as electricity, diesel, firewood, etc.). That is,

$$
E_{t}=\sum_{i=1}^{m} E_{i t}=E_{1 t}+E_{2 t}+\ldots+E_{m t}
$$

where $E_{i t}$ is the requirement of the ith energy source or carrier in the the year considered.

However, the total energy demand for the ith source $E_{i t}$ must be equivalent to the aggregate requirements of all the diverse consumer categories/sectors (such as homes, industrial units, passenger transport, freight haulage, etc.), so that

$$
E_{i t}=\sum_{j=1}^{n} E_{i j t}
$$

where $E_{i j t}$ is the energy requirement of the ith source or carrier for the jth sector in the th year.

Again, the energy demand of the jth sector $E_{i j t}$ is the sum of the energy requirements for all the p end-uses of that sector, hence,

$$
E_{i j t}=\sum_{k=1}^{p} E_{i j k t}
$$

where $E_{\mathrm{ijk}}$ is the energy requirement from the ith source or carrier used by the jth category of users for the kth end-use. in the th year.
Therefore, the total energy demand $E_{t}$ in the year $t$ is the aggregate requirement of all $\mathrm{m}$ sources or carriers, in all the $\mathrm{n}$ sectors, for all the $\mathrm{p}$ end-uses:

$$
E_{t}=\sum_{i=1}^{m} \sum_{j=1}^{n} \sum_{k=1}^{p} E_{i j k t}
$$

For each of the $p$ end-uses in the jth category of users of the ith energy source, let there be $\mathrm{N}_{\mathrm{ijk}}$ users in the year t. Let the average annual energy usage per end-use or $\left(E_{i j k} / N_{i j k}\right)$ be e eijkt. Then

$$
E_{\mathrm{ijkt}}=\mathrm{N}_{\mathrm{ijkt}} \times \mathrm{e}_{\mathrm{ijkt}}
$$

In DEFENDUS scenarios, the two parameters - the number of users $N_{i j k t}$ and the average ernrgy-usage e $i j k t-a r e$ used to introduce development objectives and efficiency improvements, respectively.

It is obvious that the number of users, $\mathrm{N}_{\mathrm{ijkt}}$, can change over time, but it is also possible that the average energy consumption per user, $\mathrm{e}_{\mathrm{ijkt}}$, for each category can also change (even if only a few users alter their consumption patterns).

Let the change in the number of users be represented by an annual growth rate, so that

$$
\mathrm{N}_{\mathrm{ijk} \mathbf{k}}=\mathrm{N}_{\mathrm{ijk}(\mathrm{t}-1)} \times\left(1+\mathrm{gijk}_{\mathrm{ijk}}\right)
$$

where $\mathrm{N}_{\mathrm{ijkt}}$ and $\mathrm{N}_{\mathrm{ijk}(\mathrm{t}-1)}$ are the number of users in the years $t$ and $(t-1)$, respectively, and gijkt is the average growth rate (in the form of a fraction = percentage/100). The growth rates (positive or negative) would depend on a combination of factors - the natural trend rates (for example, population growth) and, more importantly, those 
that are selected by the planner according to the scenario envisaged. In a DEFENDUS scenario, the development focus would determine the growth rates assigned to par. ticular sectors.

Similariy, let there be a change in the average annual energy requirement per end-use, so that

$$
e_{i j k t}=e_{i j k(t-1)} \times\left(1+c_{i j k t}\right)
$$

where $e_{i j k t}$ and $e_{i j k}(t-1)$ refer to the average energy usage per category-j consumer in the years $t$ and $(t-1)$, respectively, and $c_{i j k t}$ is the change in this usage between the years $t-1$ and $t$. This rate of change could be negative or positive as the use of more efficient devices (via technological improvements) and/or substitution of the particular energy source/carrier under consideration with another energy source/carrier would lower eijkt, while increases in energy-based activities (for instance, increase in the number of appliances per consumer) without compensating efficiency improvements would raise $e_{i j k t .}{ }^{[16]}$

Relating the total energy consumption in the year $t$ with that in the previous year via annual rates of change, i.e., from equations 5,6 , and 7 , one would get

\section{$\left(\mathrm{N}_{\mathrm{ijk}} \times \mathrm{e}_{\mathrm{ijkt}}\right)=$}

$\left\{N_{i j k(t-1)} \times\left(1+g_{i j k t}\right)\right\} \times\left\{e_{i j k(t-1)} \times\left(1+c_{i j k t}\right)\right\}(8)$ so that the energy requirement for each category of users would be:

$$
\begin{aligned}
& E_{i j t}= \\
& \sum_{k=1}^{p}\left\{N_{i j k(t-1)} \times\left(1+g_{i j k t}\right)\right\} \times\left\{e_{i j k(t-1)} \times\left(1+c_{i j k t}\right\}\right.
\end{aligned}
$$

In the special cases where the annual growth rate in the number of users remains constant from year to year (i.e., $\left.g_{i j k} 1=g_{i j k 2}=\ldots=g_{i j k t}=g_{i j k}\right)$ and where the annual changes in the average energy usage are constant (i.e., $c_{i j k 1}=c_{i j k 2}=\ldots=c_{i j k t}=c_{i j k}$, the category-wise energy requirement in the th year will be

$$
\begin{aligned}
& E_{i j t}= \\
& \sum_{k=1}\left\{N_{i j k l} \times\left(1+g_{i j k}\right)^{i-1}\right\} \times\left\{e_{i j k 1} \times\left(1+c_{i j k}\right)^{t-1}\right\}
\end{aligned}
$$

However, it may be difficult to prescribe annual rates of change in the average energy usage. Instead one can consider two types of devices for each end-use - more efficient (new or retrofitted) devices and less efficient (existing) devices. The users, $\mathrm{N}_{\mathrm{ijk}}$, can then be distinguished on the basis of the type of equipment/devices they use.

Let us refer to the ith source being used in the jth sector for the kth end-use. There are two options for the type of devices being used for this end-use - one option being those devices existing at the beginning of the scenario with the average energy usage $e_{i j k}$ and the other option being the new (or improved) devices with the energy use $e^{\prime} i j k$. The difference between $e_{i j k}$ and $e^{\prime}{ }_{i j k}$ depends on the fraction of energy, sijk, that is saved by switching to the new (or improved) devices, i.e.,

$$
\begin{aligned}
& e_{i j k}-\left(s_{i j k} \times e_{i j k}\right)=e_{i j k}^{\prime} \\
& \text { or } e_{i j k}^{\prime}=e_{i j k} \times\left(1-s_{i j k}\right)
\end{aligned}
$$

Let the "new users" be defined as all those who join the consumer population after the start (first year) of the efficiency improvement plan. These can then be treated as distinct from those counted at the start of the plan period,

$$
\text { i.e., } N_{i j k t}=\left[\left\{N_{i j k I}\right\}+\left\{N_{i j k t}-N_{i j k l}\right\}\right]
$$

or total users $=$ \{base-year users $\}+\{$ new users $\}$

But the end-use orientation might require that even the existing users acquire efficiency-improved (or retrofitted) devices. The population of users in the year $t$ would then comprise three categories, namely:

- those still with the less efficient devices prevailing at the beginning of the scenario;

- those who acquired the improved/retrofitted devices after the start of the scenario: and

- new users who start with the new improved devices. Using the above categories, if pijkt is the proportion of the base-year kth end-use devices used in the jth sector (with the ith source of energy) retrofitted in the year $t$, it follows that

$$
\begin{aligned}
\text { Total users }= & {[\{\text { those with unchanged devices }\}} \\
& +\{\text { those with retrofitted devices }\}] \\
& + \text { [new users }]
\end{aligned}
$$

$$
\begin{aligned}
& \text { or } N_{i j k t}= \\
& {\left[\left\{N_{i j k 1} \times\left(1-p_{i k j t}\right)\right\}+\left\{N_{i j k 1} \times p_{i j k t}\right\}\right]+\left[N_{i j k i}-N_{i j k 1}\right]}
\end{aligned}
$$

In this context, it may be pertinent to note that the recent DEFENDUS scenarios have, in general (as will be seen in Part II of this article, Sections 3, 5, and 6, to appear in the next issue of Energy for Sustainable Development) considered the rate of adoption of more efficient devices to approximate a logistic curve, so that

$$
p_{i j k t}=K /\left[1+\{(K-N(0)) / N(0)\} \times e^{-r t}\right]
$$

where $K$ is the saturation limit of the replacement, $N(0)$, the starting percentage taken as a negligible finite quantity, to avoid division by zero, and $r$, the constant that determines the slope of the logistic curve.

To compute the energy usage $E_{\mathrm{ijkt}}$ (with the same scheme of three categories of users), Equation 13 can be substituted in Equation 5 to yield the equation

$$
\begin{aligned}
E_{i j k t}=\left[\left\{N_{i j k l} \times\left(1-p_{i k j t}\right)\right\} \times e_{i j k}\right] \\
+\left[\left\{N_{i j k l} \times p_{i j k t}\right\} \times e^{\prime} i j k\right] \\
+\left[\left\{N_{i j k t}-N_{i j k l}\right] \times e^{\prime}{ }^{\prime} j k\right]
\end{aligned}
$$

Further, by substituting from Equation 11 , the result is

$$
\begin{aligned}
E i j k t= & {\left[\left\{N_{i j k} 1 \times(1-\text { pikjt })\right\} \times e_{i j k}\right] } \\
& +\left[\left\{N_{i j k 1} \times p_{i j k l}\right\} \times e_{i j k} \times\left(1-s_{i j k}\right)\right] \\
& +\left[\left\{N_{i j k t}-N_{i j k l}\right\} \times e_{i j k} \times\left(1-s_{i j k}\right)\right]
\end{aligned}
$$

Equation 16 can be used to compute the requirement of energy from the ith source/carrier by the jth sector for the $k$ th end-use in any year $t$.

However, if the growth rate of the number of users has been constant during the period 1 to t, i.e., $g_{i j k 1}=g_{i j k 2}$ $=\ldots=g_{i j k(t-1)}=g_{i j k}$, then one can compute the energy requirement for any year directly from the base-year energy requirement $\left(\mathrm{N}_{\mathrm{ijk} /} \times \mathrm{e}_{\mathrm{ijk}}\right)$ and the parameters entered (pijki, sijk), i.e.,

$$
\begin{aligned}
E_{i j k t}=[ & \left.\left\{N_{i j k l} \times e_{i j k}\right\} \times\left(1-p_{i k j l}\right)\right] \\
& +\left[\left\{N i j k 1 \times e_{i j k}\right\} \times p_{i j k t} \times\left(1-s_{i j k}\right)\right] \\
& +\left[\left\{N i j k t \times e_{i j k}\right\} \times\left(1-s_{i j k}\right)\right]
\end{aligned}
$$




$$
\begin{aligned}
- & {\left[\left\{N_{i j k 1} \times e_{i j k}\right\} \times\left(1-s_{i j k}\right)\right] } \\
& =\left[\left\{E_{i j k 1}\right\} \times\left(1-p_{i k j t}\right)\right] \\
& +\left[\left\{E_{i j k 1}\right\} \times p_{i j k t} \times\left(1-s_{i j k}\right)\right] \\
& +\left[\left\{E_{i j k 1} \times\left(1+g_{i j k}{ }^{i-1}\right) \times\left(1-s_{i j k}\right)\right]\right. \\
& -\left[\left\{E_{i j k 1}\right) \times\left(1-s_{i j k}\right)\right]
\end{aligned}
$$

$$
\begin{aligned}
E_{i j k t}= & E_{i j k l} \times\left[\left\{s_{i j k} \times\left(1-p_{i k j t}\right)\right]\right. \\
& \left.+\left\{\left(1-s_{i j k}\right) \times\left(1+g_{i j k}\right)^{t-1}\right\}\right]
\end{aligned}
$$

Eventually, aggregating the energy requirements over all the end-uses, sectors and sources or carriers, the total energy demand (in Equation 4) would be obtained, i.e.,

$E_{i}=\sum_{i=1}^{m} \sum_{j=1}^{n} \sum_{k=1}^{p} E_{i j k}$

\section{Appendix 3. Macro-economic implications of the DEFENDUS approach}

The requirement of energy in any sector of the economy is related to such factors as the production of that sector, the average energy prices, etc.,

$$
\text { i.e. } E=f\left(X_{1}, X_{2}, X_{3}, X_{4}, . .\right)
$$

where $E$ is the requirement of energy, and the $X_{i}$ are the determinants of demand.

Regarding the type of function, a multiplicative power function (analogous to a Cobb-Douglas production function) could be considered:

$$
E=a x_{1}^{b} \cdot x_{2}^{c} \cdot x_{3}^{d} \cdot x_{4}^{e}
$$

so that $\ln E=a+b \cdot \ln X_{1}+c \cdot \ln X_{2}+\ldots$

It follows that from the coefficients $b$, c, etc., one can gauge the effect on the dependent variable of a change in the value of the corresponding independent variable, when the other independent variables are held constant. So, if $\mathrm{X}_{1}$ is the gross domestic product from the relevant sector, then b denotes the response or elasticity of the quantity of energy required to a stimulus from sectoral production, ceteris paribus.

As an example of the regression analysis discussed in the text. consider the industrial sector of the state of $\mathrm{Kar}$ nataka. The industrial electricity usage (both low tension and high tension) from 1969-70 to 1992-93 (E) was regressed on the industrial contribution to the state domestic

\section{Notes}

1. MAFKAL was ogveioped by the Brooknaven Naionai Laboxatory (USA) and Kemtor. schungsanaace Jütich (Germany) originaly for IEA counties, tut later used tor inconesa. Erazu ano Mexico.

2. BESOM (Brockiaven Energy Systems Optimization Modef) was deveioped by the Brooknaven Nasonal Laboratory tor the USA, but also appied to Yugosiana. South Korea and Greece.

3. Deveoces by tre OF (USA), the Argonne Energy Model was used initially in the USA and later aopited to Portugat. Soun Korea and Avgentina.

4. Karnatiaka is a siate in south-western india.

5. A "scenaro" is an intended or magined sequence of events.

6. This prolect at vie Deoarment of Hanagement Sudes of the Indian institute of Science (January 1988. July 1991) was tunded by the Sweaish Internabonal Deveiopment Agency (SIDA).

7. Personal comimunicaton (1994) - Arshad Khan, K.V. Ramari and Peter Mills.

2. At the natoriai ario state ievels. wpical poicy inserments indude the market (with its Ertce mectanismi as a resource allocator or tectmorogy seiector. aoministatve allocaicen uncudinc tatronungl of energy, cadial ano tecrnology, subsidies, taxes. regulasens arcc s:arcaros. iniotmarion. research and oevelooment and instutuon-builoing.

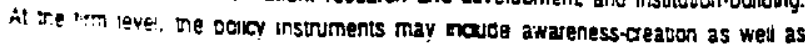

product $(G)$. The resulting equation obtained was

$$
\begin{aligned}
& \ln E=2.4177+0.5938 \ln G \\
& R^{2}=0.77
\end{aligned}
$$

Thus the elasticity of industrial electricity consumption with respect to industrial output was found to be 0.5938 .

Using the above regression equation and the level of electricity demand according to the frozen efficiency scenario (which assumes no efficiency improvement), the corresponding estimate of industrial product was Rs.109.119 billion. This estimate can be considered the upper limit because the actual elasticity will turn out to be less when efficiency improvements are incorporated.

Since the exergy end-use service levels are the same for both the DEFENDUS (efficiency improvement) scenario and the frozen efficiency DEFENDUS scenario (without efficiency improvement), the industrial output estimate corresponding to the frozen efficiency scenario, i.e., Rs.109.119 billion, can also be applicable for the DEFENDUS scenario with efficiency improvement. Taking this level of output and the electricity demand of the DE. FENDUS scenario with efficiency improvement, the implied elasticity coefficient was found to be 0.5706 . This reduction of the elasticity coefficient reflects the decrease in the energy requirement for the corresponding output level.

monetary and other incentiven Policy agents at the nationat. state and local leveis wovid induce govennerta, autonomous bodies and agencies, energy suopliers, and energy consumers.

9 Econometrics indres the appititation of mathemation and satsticat tecrniques :0 economic problass.

10. This inplies that the "ufirif derived by each user tom energy usage is fixed at the base-year level but the wat nimber of users increases.

11. Spreadsheet-based sothrer (LOTUS 1-2-3, Supercalc Ouattro Pro, Excel. e.c.) and financial calatrors give imananeous resuits tor PVs ano amorwation: even neratve calculations ior rates of raum are acompished quicky, eliminatng the need for specitying atgouthins.

12. The order in wich the rrious tectinoiogies appear in the mix coes not imoly a chronoiogical sequence. in tact at the optons that are neeced to reacn the energy requirement should bo stated simulaneousiy.

13. These are calouted to refect the actual economic value of the inouts. rather man the adminsteree prices (utich could inciuos additional subsioies or dutesl.

14. This is equivalert to the enstcity of energy requirement mth respect to orocuction.

15. If the energy consumotion in this year is acnormal either oue to some Doricy-imooses

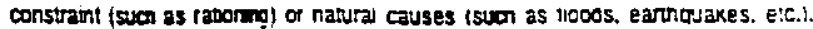
this deviaton tom the nomal snouid be aojusted sutably to ostan tre "tue" ro. quirement 
16. Shitts from one energy source to another would also change the dentand tor the relevant energy sources.

\section{References}

Banerjee, R., 1991. "DEFENDUS: towards evotving a rational energy policy", in Economic and Political Weekly, Vol. XXVI, No. 44, November 2 pp. $2539-2540$.

Buehning, W.A., Hamilton, B.P., Guziè. KA, and Cirillo, R.R, 1991. "ENPEP (Energy and Power Evaluation Program) - an integrated approact for modeling national energy systems", Argonne National Laboratory.

Central Power Research institute (CPRI), 1987. Energy Requirement up to 2001 AD. Central Electricity Authority (CEA), 1985. Twelth Electric Power Survey of incia, New Deihi. Central Electricity Authority (CEA), New Delhi, 1987. Thirteenth Electric Power Survey of india.

Committee, headed by S.G. Ramactianda, for the Long-Range Planning for Power Projects, Government of Karnataka (LRPPP.GOK), 1987. A Report on Long-Range Plan for Power Projects in Kamataka 1987-2000 A.D.

Enerdata SA. 1993. Sudy of an Energy Demand Projection Model for Atrican Cauntries, Draft Final Report, 2 Avenue de Vignate, 38610 Gieres, France.

Goidemberg. J, Johansson, T.B, Reddy, A.K.N, and Willians, R.H, 1988. Enemy for a Sustainable World, Wiley Eastern Lto.

Goldstein, GA, and Hamilton, LD., 1990. "PC-MARKAL and the MARKAL User Suppor Systern (MUSS): User's Guide, BNL-46319", Brookhaven National Laboratory Associated Universities lnc.

Government of Karnataka (GOK), 1982 "Power: prospects and policies", - background paper presented to the Economic and Planning Council.

LEAP, 1990. LEAP - A Computenzed Energy Ptanning System - Vol. I: Overvien, Volll: User Guide, Vod. III: Technical Description, Version 90.01, Stockholm Environment institute, Boston Cemter, Fellus institute for Rescurce and Emironmental Strategies (earlier the Energy Systems Research Group), Boston.

MEDEE.S, 1995. MEDEE.S - Sectoral Energy Denand Analysis and Forecast, Version 12. The Econornic and Social Commission for Asia and the Paciic (ESCAP). The Urited Nations Development Programme and The Government of France in collaboration with Asian Institute of Techrology (EPCCT/AIT), Programme tor Asian Cooperation on Energy and the Enviro nment (PACE-E), RAS/9207t, February. (This is the tatest version of the sofware: the firs PC version MEDEE.S 1.0 was developed oy B. Lapilonne. IEFE, France in 1985.)

Meier, P., 1985. "Energy plaming in deveioping counties: the role of microcomputers", in Natural Resources Forum, Vo. 9 No. 1. United Nations, New York.

Pachauri, R.K., and Srivastara, L., 1988. "integrated energy planning in India: a modelling approach", The Energy Joumal, Vol. 9, No. 4.

Pachauri, R.K., Dayal, H.V., and Ravishankar, K.. 1980. Administrabive Staff College of India. "Repont on the development of a forecasting model and demand projections for power deveiopment in Kamataka", submitted to the Power and Energy Division. Pianning Commission, Government of incia, New Delhi.

Parikh, J., 1991. "From 'DEFENDUS' to consensus", in Economic and Political Weekdy, Vol. XXVI, No. 25, June 22, pp. 1566-68.

Perspective Planning Division (PPD), Ptanning Dept, Govemment of Karnataka (GOK), 198:. "Demand pattern of energy in Kamataka: present and projected".

Planning Department, Govenment of Karnataka (PD-GOK). 1989. "Report of the Working Group on energy for the Eghth Five-Year Plan 1990-95", presented at the seminar on "Kamataka's Eighth Five-Year Plan Perspective", Institute tor Social and Economic Change, Bangatore 560072, November 16-17.

Public Works and Electricity Department, Government of Kannataxa (PWEO-GOK), 1983 "Report of the Committee constituted by the Economic and Planning Council tor the forecast of energy requirement and avaitability to 1989.90".

Feddy, A.K.N., Sumithra, D.G., Balachandra, P., and D'Sa, A, 1990. "Comparative costs of electricity conservation, centralized and decentralized electricity generation", published as a Special Articie in Economic and Political Weekly, Vol. XXV, No. 22. June 2, pp. 1201-1216.

Reddy, A.K.N., Sumithra, D.G., Balacnandra, P., and D'Sa, A. 1991. "A devetooment-focused end-use-oriented scenerio for Kamataxa" - Special Aticie in Economic and Politica Weekiy, Vol. XXVI. Nos. 14 \& 15, April 6 \& April 13, po. 891-910 \& 983-1001.

Relter, A, 1990. "MESAP - Micro-comouter based energy sector analysis and planning system - Overview brochure", University of Stuttgart.

Shah, J.C., 1991. "DEFENDUS - how?', in Economic and Political Weekly, Vol. XXVI, No. 42. October 19, pp. 2435-2440.

Working Group, Govemment of Kamataka (WG.GOK), 1982. "Report of the Working Group constituted for advance planing for utilization of power in Kamataka".

\section{Energy for Sustainable Development accepts advertisements dealing with energy conservation or promotion of renewable energy}

\section{Tariff (in US dollars)}

\begin{tabular}{|c|c|c|c|}
\hline 1. Cover pages (in 4 colour) & $\begin{array}{l}\text { One } \\
\text { issue }\end{array}$ & $\begin{array}{l}3 \text { issues } \\
\text { in a year }\end{array}$ & $\begin{array}{l}\text { All } 6 \\
\text { issues in } \\
\text { a year }\end{array}$ \\
\hline Back cover & 600 & 1600 & 3000 \\
\hline Inside covers & 480 & 1280 & 2400 \\
\hline 2. Text pages (black \& white) & & & \\
\hline Full page & 160 & 400 & 720 \\
\hline Half a page & 80 & 200 & 360 \\
\hline \multicolumn{4}{|c|}{$\begin{array}{l}\text { 3. Classified advertisements } \\
\text { a. Per word US cents } 40 \text {, minimum number of words } 50 \\
\text { maximum number of words } 250 \\
\text { b. Box service US } \$ 10 \text { per month. The box will be kept } \\
\text { open for a maximum of four months }\end{array}$} \\
\hline
\end{tabular}

Indian advertisers can contact the Executive Editor for rupee tariff. Organisations placing advertisements directly with Energy for Sustainable Development will get a $15 \%$ discount on tariff.

Write to:

The Executive Editor

Energy for Sustainable Development

$25 / 5$, Borebank Road

Benson Town

Bangalore - 560 046, INDIA

Phone: ++91805543563

Fax: ++91805548426 
ANEXO - 5 


\section{CENÁRIO REFERÊNCIA I}

\begin{tabular}{|c|c|c|c|c|c|c|c|}
\hline \multirow{3}{*}{ ano-base: 1995} & \multicolumn{7}{|c|}{ proporcão por nivel de produtividade } \\
\hline & & 0,5150 & 0,1780 & 0,1810 & 0,1260 & & dados totais \\
\hline & niveis de pradut & 0,750 & 1,500 & 4,000 & 7,000 & & milho \\
\hline & unidades & & & & & & \\
\hline producso 39 ricola & $1000 t$ & 5347631 & 3696615 & 10023780 & 12211290 & & 31279316 \\
\hline area & ha & 7130175 & 2464410 & 2505945 & 1744470 & & 13845000 \\
\hline produtuvidade & tha & 0,750 & $1.500^{\circ}$ & 4,000 & 7,000 & & 2,259 \\
\hline$\%$ area empregando N FMN & 0.0 & 0,00 & $0,090^{\circ}$ & 0.42 & 0.50 & & 0.16 \\
\hline área utilizando N-FMN & ha & 0 & 221797 & 1052497 & 872235 & & 2146529 \\
\hline producäo com N-FMVIN & 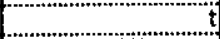 & 0,0 & 332695 & 4209988 & 6105645 & & 10648328 \\
\hline hecessidadde de N-FMNIt output & $\mathrm{kg} \mathrm{N} / \mathrm{t}$ on out & 180 & 18,0 & 180 & 180 & & 15.0 \\
\hline N-FMN aplicado/ha & $\mathrm{kg} \mathrm{N} / \mathrm{ha}$ & 0,0 & 27,0 & 72,0 & 1260 & & 89.3 \\
\hline N-FMIITOOTAL & lons N-fe:t & 0 & 5989 & 75760 & 109902 & & 191670 \\
\hline proporgäo N/FMN & tferti N & 3.5548 & 3,5548 & 3,5548 & 3.5548 & & \\
\hline fertilizante & FMN & 0 & 21288 & 269382 & 390678 & & 681348 \\
\hline amonis & tamônialt FMN & 0,3875 & 0.3975 & 0,3975 & 0,3875 & & 45,00 \\
\hline amônia & tamônia & o & 8249 & 104386 & 151388 & & 264022 \\
\hline energia & Gjitamônia & 36,89 & 36,89 & 36.89 & 36,89 & & \\
\hline energia & G total & 0 & 304309 & 3850781 & 5584697 & & 9739797 \\
\hline produtividade & tha & 0,750 & 1,500 & 4.000 & 7,000 & & 2.259 \\
\hline
\end{tabular}

\begin{tabular}{|c|c|c|c|c|c|c|c|}
\hline & & & & hiveis de proc & utividade & & dados totais \\
\hline ano 2000 & unidades & taxas (\%a.a.) & 0,750 & 1,500 & 4,000 & 7,000 & milno \\
\hline produca agricola estimada & самит & $2,66 \%$ & 5428328 & 3874997 & 11726438 & 14645515 & 35675279 \\
\hline area & ha & 0,30 & 7237771 & 2501599 & 2543760 & 1770795 & 14053925 \\
\hline$\%$ area empreganoo $\mathrm{N}-F M \mathrm{M}$ & $\%(0.0)$ & estimado & 0.00 & $0,030^{\circ}$ & 0,42 & 0,50 & 0,155 \\
\hline area utilizando $N-F M N$ & ha & & 0 & 225144 & 1068379 & 885397 & 2178921 \\
\hline cremerto na area com $\mathrm{N}-\mathrm{FMN}$ & $\%(00)$ & & 0,000 & 0,000 & 0,000 & 0,000 & 0,000 \\
\hline produca com N-FMN & t & & 0 & 450315 & 5824914 & 8447735 & 14732064 \\
\hline necessidade de N-FMMNit output & kgNi/t output & dado & 18,00 & 18,00 & 18,00 & 18,00 & 15,00 \\
\hline N-FMN aphodolhal & kgNiha & 6.39 & o' & 37 & 98 & "'m"'t72 & 12171 \\
\hline N-FMN TOTAI & ns N-fert & $6,71 \%$ & 0 & 8286 & 104848 & 152059 & 265193 \\
\hline proporcá NIFMN & terertit N & & 3,5548 & 3,5548 & 3,5548 & 3,5548 & \\
\hline fertiliz & TFMN & & 0 & 29454 & 372715 & 540540 & 942709 \\
\hline ônia & nIaAt FMN & & 0,3875 & 03875 & 0,3875 & 0,3875 & \\
\hline amônia & amônia & & on. & 11413 & 144427 & 209459 & 365300 \\
\hline energia & GJittamônia & & 36,89 & 36,89 & 36,89 & 36.89 & \\
\hline energia & Gs total & & o & 421040 & 5327918 & 7726953 & 13475912 \\
\hline produtividade com FMN & tha & & 0,000 & 2,045 & 5,452 & 9,541 & 6,762 \\
\hline orodiutividade total por nivei & & & 0,750 & 1,549 & 4,610 & 8,271 & 2,533 \\
\hline
\end{tabular}

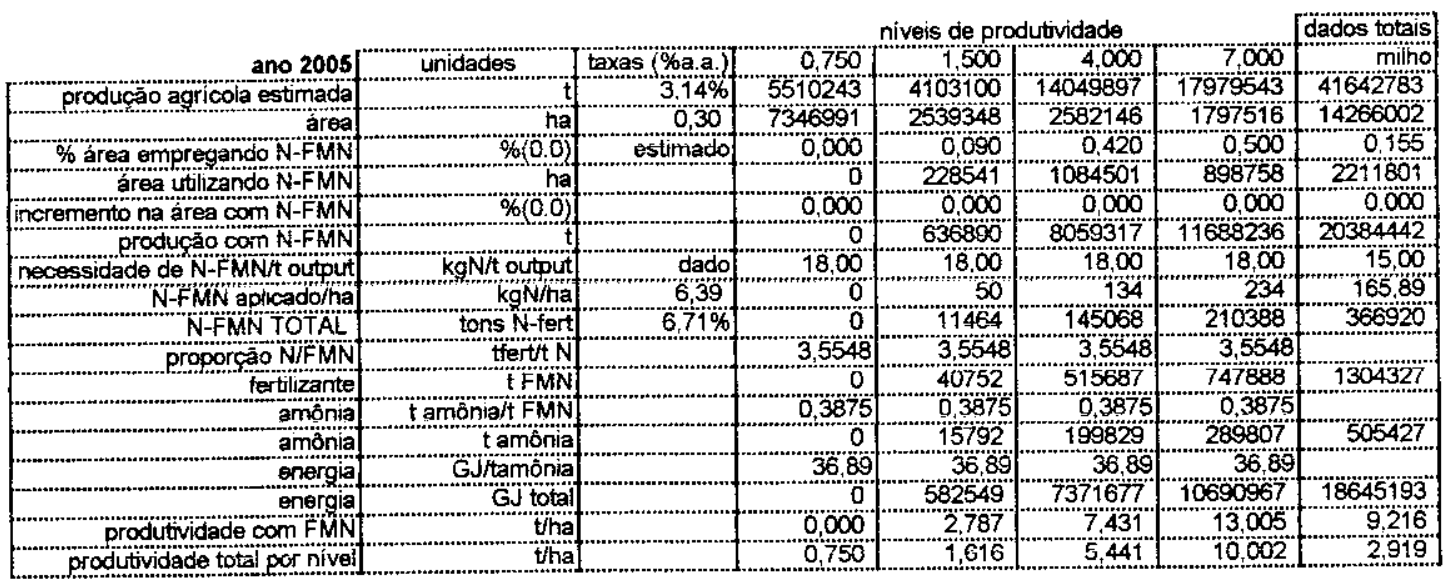

\begin{tabular}{|c|c|c|c|c|c|c|c|}
\hline & & & \multicolumn{4}{|c|}{ niveis de produtividade } & [dados totais \\
\hline ano 2010 & unidades & taxas (\%a.) & 0,750 & 1,500 & $4,000^{\circ}$ & 7,000 & mitho \\
\hline producáo agrícola estimada & 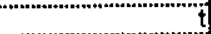 & $1,78 \%$ & 5593394 & 4399713 & 17231803 & 18250859 & 45475770 \\
\hline area & ha & 0,30 & 7457859 & 2577668 & 2621112 & 1824641 & 14481280 \\
\hline \% area empregando N-FMN & $\%(00)$ & estimado & 0,000 & 0,090 & 0.420 & 0.500 & 0,155 \\
\hline area utilizando N-FMN & ha & & 0 & 231900 & 1100867 & 912321 & 2245178 \\
\hline incremento na area com N-FMN & $\%(0.0)$ & & 0,000 & 0.00 & 0,000 & 0,000 & 0,000 \\
\hline produca com N-FMN & $t$ & & 0 & 881197 & 11150824 & 11864615 & 23896635 \\
\hline necessidade de N-FMNit output & kgNitit output & dado & 1800 & 18,00 & 18,00 & 18,00 & 15,00 \\
\hline N-FMN apicadoiha & kgN/ha & 6.39 & 0 & 68 & 182 & 234 & 191,58 \\
\hline N-FMNTOTAL & tons N-fert & $3,23 \%$ & 0 & 15862 & 200715 & 213563 & 430139 \\
\hline proporso N/FMN & tfertit N & & 3,5548 & 3,5548 & 3,554 & 35548 & \\
\hline tertizante & $t F M$ & & 0 & 56305 & 713501 & 759174 & 1529060 \\
\hline amónia & tamoniart FMN & & 0,3875 & 0,3875 & 0,3875 & 0,3875 & \\
\hline amónia & tamónia & & on & 21849 & 276482 & 294180 & 592511 \\
\hline energia & Gijtamônia & & 36,89 & 3689 & 36,89 & 36,89 & \\
\hline energia & GJ total & & o & 806011 & 10199408 & 10852297 & 21857716 \\
\hline produtividade com FMN & tha & & 0,000 & 3798 & 10,129 & 13,005 & 10,644 \\
\hline produtividade total por nivel & tha & & 0,750 & 9707 & 6.574 & 10.002 & 3,140 \\
\hline
\end{tabular}




\section{CENÁRIO MANEJO EFICIENTE I}

\begin{tabular}{|c|c|c|c|c|c|c|}
\hline \multirow{3}{*}{ ano-base: 1995} & \multicolumn{6}{|c|}{ proporcajo por nivel de produtividade } \\
\hline & & 0,5150 & 0,1780 & 0.1810 & 0,1260 & dados totais \\
\hline & niveis de produt & 0,750 & 1,500 & 4.000 & 7,000 & milho \\
\hline & unidades & & & & & \\
\hline producăo agrícola & $1000 \mathrm{t}$ & 5347631 & 3696615 & 10023780 & 12211290 & 31279316 \\
\hline area & ha & 7130175 & 2464410 & 2505945 & 1744470 & 13845000 \\
\hline proctutividade & that & 0,750 & 1.500 & 4,000 & 7,000 & 2,259 \\
\hline$\%$ area empregando N-FMN & 0.0 & 0,00 & 0.090 & 0.42 & 0,50 & 0,16 \\
\hline area utilizando $N-F M N$ & nat & 0 & 221797 & 1052497 & 872235 & 2146529 \\
\hline producâo com N-FMN & $t$ & 0,0 & 332695 & 4209988 & 6105645 & 10648328 \\
\hline ecessidadde de N-FMN/t output & $\mathrm{kg} \mathrm{N} / \mathrm{ton}$ out & 18,0 & 18,0 & 18,0 & 18,0 & 18,0 \\
\hline N-FMN aplicado/ha & $\mathrm{kg} \mathrm{N} / \mathrm{ha}$ & 0,0 & 27.0 & 72,0 & 126.0 & 88,5 \\
\hline N-FMN TOTAL & tons N-fert & 0 & 5989 & 75780 & 109902 & 190000 \\
\hline proporcao N/FMN & tfertín & 3,5548 & 3.5548 & 3.5548 & 3,5548 & \\
\hline fertilizante & TFMN & 0 & 21288 & 269382 & 390678 & 681348 \\
\hline amônia & t amóniat FMN & 0,3875 & 0,3875 & 0.3875 & 0.3875 & \\
\hline amôna & tamôna & 0 & 8249 & 104386 & 151388 & 264022 \\
\hline energia & GJitamónia & 36,89 & 36.89 & 36,89 & 36,89 & \\
\hline energia & Gs total & 0 & 304309 & 3850781 & 5584697 & 9739787 \\
\hline produtividade & Uha & 0,750 & 1,500 & 4,000 & 7,000 & 2,259 \\
\hline
\end{tabular}

\begin{tabular}{|c|c|c|c|c|c|c|c|}
\hline & & & \multicolumn{4}{|c|}{ niveis de produtividade } & dados totais \\
\hline ano $2000 \mathrm{~J}$ & unidades & axas (\%a.a.) & 0,750 & 1.500 & 4,000 & 7,000 & mitio \\
\hline producâo agricola estimada & t & $2,66 \%$ & 5428328 & 3874997 & 11726438 & 14645515 & 35675279 \\
\hline area & hat & 0,30 & 7237771 & 2501599 & 2543760 & 1770795 & 14053925 \\
\hline \% area empregando N-FMN & $\%(00)$ & estimado & 0.000 & 0,090 & 0,420 & 0.500 & 0,155 \\
\hline area utilizando N-FMN & hat & & 0 & 225144 & 1068379 & 885397 & 2178921 \\
\hline ncremento na area com $N$-FMN & $\%(00)$ & & 0,000 & 0,000 & 0,000 & 0.000 & 0,000 \\
\hline produça com N-FMN & & & 0 & 460315 & 5824914 & 8447735 & 14732964 \\
\hline necessidade de N-FMNAt output & $\mathrm{kgNh}$ output & dado & 18,00 & 18,00 & 18,00 & $\$ 8.00$ & 18,00 \\
\hline N-FMN aplicado/hat & $\mathrm{kgN} / \mathrm{ha}$ & 6,39 & 18,00 & 36,80 & 98,14 & 171.74 & 12171 \\
\hline N-FMN TOTALI & tons $N$-fert & $6,90 \%$ & 0 & 8286 & 104848 & 152059 & 265193 \\
\hline primeira medida - BNCORPORAF & & & 1.0 & 1,0 & 1,0 & 10 & \\
\hline$\%$ da area nova adolando & 0,0 & & \#DIVIO! & 0,000 & 0,000 & 0.000 & \\
\hline IN-FMN equivalente & & & \#DIVIO! & 0 & of & 0 & \#DIVIO! \\
\hline$\%$ total de N-fert afetada & 0,0 & & 0,7 & 0,7 & 0,7 & 0.60 & \#DIVIOL! \\
\hline tdeN-fert & & & \#DIVIO! & 0 & 0 & 0 & \#DVIO! \\
\hline potencial de economizar & 0.0 & & 0.15 & 0,15 & 0,15 & 0.20 & FDIVIO! \\
\hline total economizado & $t$ & & \#DIVIO! & 0 & 0 & 0 & HDIVIOI! \\
\hline NOVO CONSUMO DE N-fert $>$ & $t$ & & \#DIViO! & 8286 & 104848 & 152059 & \#DIVIO! \\
\hline$\%$ economizada o/ 1 medida & & & 0,000 & 0,000 & 0,000 & 0,000 & \#DIVIo! \\
\hline Unda medida - ADUCZO VERDE & & & & & & & \\
\hline \% da area nova adotando & 0,0 & & 0,000 & 0,000 & 0,000 & 0,000 & \\
\hline IN-FMN equivalente & $t$ & & of & 0 & of & 0 & 0 \\
\hline \% total de N-fert afetada & 0.0 & & 0.700 & 0,700 & 0,700 & 0.360 & 0,000 \\
\hline tdeN-fert & if & & 0 & -0 & of & 0 & 0 \\
\hline potencial de economizar & 0,0 & & 9,0 & 1,0 & 1,0 & 1,0 & 0,000 \\
\hline totâl economizado & t & & 0 & 0 & 0 & 0 & 0 \\
\hline NOVO CONSUMODE N-fert2> & t & & \#DIVR! & 8286 & 104848 & 152059 & \#DIVIOI" \\
\hline$\%$ economizada $\mathrm{c} / 2$ medida & 0,0 & & 0,000 & $0,0,00$ & 0,000 & 0.000 & 0,000 \\
\hline$\%$ economizada totai & 0,0 & & \#DIVN! & 0,0000 & 0,0000 & 0,0000 & \#DIVIO! \\
\hline area útilizando adubo verde & ha & & 0 & 0 & 0 & 0 & -0 \\
\hline$\%$ & & & 0,000 & 0,000 & 0,000 & 0,000 & 0,000 \\
\hline INCORPORAR & ha & 0,05 & of & 11090 & 52625 & 43612 & 107326 \\
\hline IN-FMN equivalente & t & & 0 & 408 & 5164 & 7490 & 13062,6 \\
\hline \% tota de N-fer afetada & 0,0 & & 0,70 & 0,70 & 0,70 & 0,60 & 0,032 \\
\hline toeN-tmn & if & & of & 286 & 3615 & 4494 & 8395 \\
\hline potencial de economizar & 0,01 & & 0.15 & 0,15 & 0,15 & 0.2 & \\
\hline total economizado & if & & of & 43 & 542 & 899 & 1484 \\
\hline NOVO CONSUMO DE N-fert3> & t & & \#DIVIO! & 8243 & 104306 & 151160 & 263709 \\
\hline proporcāo N/FMN & tfertt N & & 3.5548 & 3,5548 & 3.5548 & 3.5548 & \\
\hline fertilizante & $t F M N$ & & HDIVIO! & 29302 & 370788 & 537345 & 937434 \\
\hline amônia & Tamoniat FMN & & 0,3875 & 0,3875 & 0,3875 & 0,3875 & \\
\hline amónia & tamônia & & \#DIVIO! & 11354 & 143680 & 208221 & 363256 \\
\hline energia & GJ/tamónia & & 36,89 & 36,89 & 36,89 & 36.89 & \\
\hline energia & GJ total & & \#DIVIO! & 418863 & 5300363 & 7681281 & 13400506 \\
\hline produtividade corm FMN & vha & & 1,750 & 2,045 & 5452 & 9,541 & 6,762 \\
\hline produtividade totaj por nivel I & tha & & 0,750 & 1,549 & 4,610 & 6.271 & 2,538 \\
\hline
\end{tabular}




\begin{tabular}{|c|c|c|c|c|c|c|c|}
\hline & & & \multicolumn{4}{|c|}{ niveis de produtividade } & dados totais \\
\hline ano 2005 & Lijuades & axas (\%a a. $)$ & 0,750 & $1.500]$ & 4,000 & 7,000 & minitus \\
\hline producăo agricola estimada & tons & $3,14 \%$ & 5510243 & 4103100 & 14049897 & 17979543 & 41642783 \\
\hline area & na & 0,301 & 7346991 & 2539346 & 2582146 & 1797516 & 14266002 \\
\hline \% area empregando N-FMN & 0,0 & estimado & 0000 & 009 & 0.420 & 0,500 & 0155 \\
\hline area utilizando $\mathrm{N}-\mathrm{FMN}$ & nat & & 0 & 228541 & 1084501 & 898758 & 2211801 \\
\hline ncremento na area com N-FMN & $\%(0.0)$ & & 0,000 & 0.000 & 0,000 & 0,000 & 0,000 \\
\hline produçao com N-FMN & -1 & & 0 & 636890 & 8059317 & 11688236 & 203384442 \\
\hline necessidade de N-FMNAt output & $\mathrm{kgNAt}$ outout & dado & 18,00 & 18,00 & 18,00 & 18,00 & 18,00 \\
\hline N-FMN aplicadoina & $\mathrm{kgN/ha}$ & 6,39 & 24.53 & 50,16 & 133.76 & 23409 & 16589 \\
\hline N-FMN TOTAL & tons $\mathrm{N}$-tert & $6,71 \%$ & 0 & 11464 & 145068 & 210388 & 366920 \\
\hline primeira medida-iN CORPORAF & & & 1,00 & 1,00 & 1,00 & 1,00 & \\
\hline \% da área nova adotando & 0,0 & & \#DIVIO! & 0.000 & 0,000 & 0,000 & \\
\hline tN-FMN equivalente & if & & \#Divio! & of & 0 & 0 & \#DIVIO: \\
\hline$\%$ total de $\mathrm{N}$-fert afetada & 0,0 & & 0,7 & 0,7 & 0,7 & 0.6 & \#DiVo! \\
\hline ton-fert & t & & \#DIVIO! & of & 0 & of & \#DIVIO: \\
\hline potencial de economizar & 0,0 & & 0,15 & 0,15 & 0.15 & 0,20 & \#DIVIO! \\
\hline total economizado & -1 & & HDIVIO! & of & 0 & -1 & \#DIVIO! \\
\hline NOVO CONSUMO DE N-fert?> & t & & "HDIVIO!" & 11464 & 145068 & 210388 & \#DIVIo! \\
\hline$\%$ economizada $\mathrm{d} / 1$ medida & & & \#DIVIO! & 0,0000 & 0,0000 & 0.0000 & \#DIV10! \\
\hline Unda medida - ADUBBO VERDE & & & & & & & \\
\hline \% da area nova adótando & 0,0 & & 0.000 & 0,000 & 0,000 & 0.000 & \\
\hline IN-FMN equivalente & $t$ & & 0 & of & of & 0 & 0 \\
\hline \% total de N-fert afetada & 0,0 & & 0,7 & 0,7 & 0,7 & 0,3 & 0.000 \\
\hline ton-fert & 1 & & 0 & of & 0 & 0 & -1 \\
\hline potencial de economizar & 0,0 & & 10 & 101 & 10 & 1,0 & \\
\hline total economizado & $t$ & & 0 & 0 & 0 & 0 & 0 \\
\hline NOVO CONSUMO DE N-fert2> & $t$ & & HDivio! & 11464 & 145068 & 210388 & \#DIVIO! \\
\hline$\%$ economizada $c / 2$ medida & 0,0 & & \#DIVI0! & 0,0000 & 0,0000 & 0,0000 & 0,000 \\
\hline$\%$ economizada total & 0,0 & & \#OIVIO! & 0,0000 & 0,0000 & 0,0000 & \#DIVIO! \\
\hline área utilizando adubo verde & ha & & 0 & 0 & 0 & 0 & 0 \\
\hline$\%$ & & & 0,0000 & 0,0000 & 0,0000 & 0,0000 & 0,0000 \\
\hline INCORPORAR & ha & 0,10 & 0 & 22180 & 105250 & 87224 & 214653 \\
\hline IN-FMN equivalente & $t$ & & 0 & 1113 & 14079 & 20418 & 35609 \\
\hline \% total de N-fert afetada & 0,0 & & 0,7000 & 07000 & 07000 & 03000 & 0,046 \\
\hline tde N-fmn & t & & -1 & $\begin{array}{r}779 \\
-7-19\end{array}$ & 9855 & 6125 & 16759 \\
\hline potencial de economizar & 0,0 & & 0,15 & 0,15 & 0,15 & 0.2 & \\
\hline total economizado & t & & 0 & 117 & 1478 & 1225 & 2820 \\
\hline NOVO CONSUMO DE N-fert3> & if & & ADIVIO! & 11347 & 143589 & 209163 & 364100 \\
\hline proporcáo N/FMN & thertit N & & 3,5548 & 3.5548 & 3.5548 & $\begin{array}{r}3,5548 \\
\end{array}$ & \\
\hline fertilizante & tFMN & & \#DIVIO! & 40337 & 510432 & 743533 & 1294302 \\
\hline amónia & tamônian FMN & & 0,3875 & 0.3875 & 0,3875 & 0,3875 & \\
\hline amôniä & tamônia & & \#DIVIo! & 15631 & 197792 & 288119 & 501542 \\
\hline energia & GJAtamónia & & 36,89 & 36,89 & 36,89 & 36.89 & \\
\hline energia & GJtotal & & \#QIVIO! & 576612 & 7296558 & 10628715 & 18501885 \\
\hline produtividade com FMN & $t / b a$ & & 2.113 & 2,787 & 7,431 & 13,005 & 9216 \\
\hline produtividade total por niveil & Uha & & 0,750 & 1,616 & 5441 & 10,002 & 2.919 \\
\hline
\end{tabular}

\begin{tabular}{|c|c|c|c|c|c|c|c|}
\hline & & & \multicolumn{4}{|c|}{ niveis de produtividade } & dados totais \\
\hline ano 2010 & unidades: & axas (\%a.a.) & 0,750 & 1,500 & 4,000 & 7,000 & milho \\
\hline producào agricola estimada & tons & $1,78 \%$ & 5593394 & 4399713 & 17231803 & 18250859 & 45475770 \\
\hline area & ha & 0,30 & 7457859 & 2577668 & 2621112 & 1824641 & 14481280 \\
\hline \% ăres empregando N-FMN & 0,0 & estimado & 0,000 & 0.090 & 0.420 & 0,500 & 0.155 \\
\hline area utlizando N-FMN & ha & & 0 & 231990 & 1100867 & 912321 & 2245178 \\
\hline ncremento na area com N-FMN & $\%(0.0)$ & & 0,000 & 0,000 & 0,000 & 0,000 & 0.000 \\
\hline produgáo com N-FMN & $-m$ & & 0 & 881197 & 11150824 & 11864615 & 23896635 \\
\hline necessidade de N-FMMNA output & $\mathrm{kgN/}$ output & dado & 18,00 & 18,00 & 18,00 & 18.00 & 18,00 \\
\hline N-FMN aplicado/ha & $\mathrm{kgN} / \mathrm{ha}$ & 6,39 & 33,44 & 68,37 & 182,32 & 234,09 & 191.58 \\
\hline N-FMN TOTAL & tons $\mathrm{N}$-fert & $3,23 \%$ & 0 & 15862 & 200715 & 213563 & 430139 \\
\hline primeira medida - INCORPORA & & & 1,0 & 1,0 & 1.0 & 10 & \\
\hline \% da área nova adotando & 0,0 & & \#DIVIO! & 0,000 & 0,000 & 0,000 & \\
\hline IN-FMN equivalente & f & & \#DIVIOI! & -1 & 0 & of & \#ÜIVIOL! \\
\hline \% total de N-fert afetada & 0,0 & & 0,7 & 0,7 & 0,7 & 0,6 & \#Divioio! \\
\hline t de N-fert. & t & & \#DIV/o! & of & 0 & 0 & \#DIVIO! \\
\hline potencial de economizar & 0,0 & & 0,15 & 0.15 & 0,15 & 0,20 & \#DIVIO \\
\hline total economizado & $t$ & & \#OIVIO! & 0 & of & 0 & \#DIVIO! \\
\hline NOVO CONSUMO DE N-fert $1>$ & if & & \#OIVIO! & 15862 & 200715 & 213563 & \#DIVIO! \\
\hline \% economizada $\mathrm{c}$ i medida & & & \#DIVIO! & 0,000 & $0,000^{\circ}$ & 0.000 & \#DIVIO! \\
\hline Unda medida - ADUBO VERDE & & & & & & & \\
\hline \% da area nova aóotando & 0,0 & & 0,000 & 0,000 & 0,000 & 0,000 & \\
\hline t N-FMN equivalente & $t$ & & of & 0 & 0 & 0 & 0 \\
\hline \% total de N-fert afetada & 0,0 & & 0,700 & 0,700 & 0,350 & 0,240 & 0,000 \\
\hline t de N-fert & t & & - & 0 & of & 0 & 0 \\
\hline potencial de economizar & 0,0 & & 1,0 & 1,0 & 1,0 & 10 & \\
\hline total economizado & $t$ & & 0 & of & of & 0 & 0 \\
\hline NOVO CONSUMO DE N-fert $2>$ & t & & \#DIV/O! & 15862 & 200715 & 213563 & \#ÖIVI! \\
\hline$\%$ economizada $d / 2$ medida & 0.0 & & \#DIV/o! & 0,000 & 0,000 & 0,000 & 0.000 \\
\hline \% economizada total & 0,0 & & \#OIVIO! & 0,000 & 0,000 & 0,000 & \#DIVIO! \\
\hline área utilizando adubo verde & ha & & 0 & 0 & 0 & 0 & 0 \\
\hline$\%$ & & & 0,0000 & 0,0000 & 0,0000 & 0,0000 & 0.0000 \\
\hline INCORPORAR & hat & 0,15 & -0 & 332701 & 157875 & 130835 & 321979 \\
\hline tN-FMN equivalente & ti & & 0 & 2275 & 28784 & 30627 & 61686 \\
\hline \% total de N-fert afetada & 0,0 & & 0,7000 & 0,7000 & 0,3500 & 0,2400 & 0,044 \\
\hline t de N-fmn & t & & of & 1592 & 10075 & 7350 & 19017 \\
\hline potenciai de economizar & 0.0 & & 0,15 & 0,15 & 0,15 & 0,2 & \\
\hline total economizado & $t$ & & 0 & 239 & 1511 & 1470 & 3220 \\
\hline NOVO CONSUMO DE N-fert3> & $t$ & & \#DIVIO! & 15623 & 199204 & 212093 & 426919 \\
\hline proporcáo N/FMN & tfert N & & 3.5548 & 3.5548 & 3,5548 & 3,5548 & \\
\hline fertilizante & $t F M N$ & & \#DIVIO! & 55536 & 708129 & 753948 & 1517613 \\
\hline amônia & t amôniart FMN & & 0,3875 & 0,3875 & 0,3875 & 0,3875 & \\
\hline amónia & tamônia & & \#DIVIO! & 21520 & 274400 & 292155 & 588075 \\
\hline energia & GJ/tamóniä & & 36,89 & 36,89 & 36,89 & 36,89 & \\
\hline energia & G. totai & & \#OIVIO! & 793874 & 10122617 & 10777594 & 21694085 \\
\hline produtividade com FMN & tha & & 2,608 & 3,798 & 10,129 & 13,005 & 10,644 \\
\hline produtividade total por nivej & & & 0,750 & 1,707 & 6,574 & 10,002 & 3,140 \\
\hline
\end{tabular}




\section{CENÁRIO ADUBO VERDE I}

\begin{tabular}{|c|c|c|c|c|c|c|}
\hline & \multicolumn{6}{|c|}{ proporçào por nivel de procutividade } \\
\hline ano-base: 1995 & & 0.5150 & $0.1780^{\circ}$ & 0,1810 & 0,1260 & dados totais \\
\hline & niveis de produt. & 0,750 & 1,500 & 4,000 & 7,000 & milho \\
\hline & unidades & & & & & \\
\hline produça agricola & $1000 t$ & 5347631 & 3696615 & 10023780 & 12211290 & 31279316 \\
\hline area & ha & 7130175 & 2464410 & 2505945 & 1744470 & 13845000 \\
\hline produtividade & tha & 0,750 & 1,500 & 4,000 & $7,000^{\circ}$ & 2,259 \\
\hline$\%$ area empregando $\mathrm{N}-\mathrm{FMN}$ & 0,0 & 0,0 & 0.090 & 0.42 & 0.50 & 0,16 \\
\hline area utitizando $\mathrm{N}-F M \mathrm{~N}$ & hat & 0 & 221797 & 1052497 & 872235 & 2146529 \\
\hline producá com N-FMN & $t$ & 0,0 & 332695 & 4209988 & 6105645 & 10648328 \\
\hline necessidade de N-FMN/t output & $\mathrm{kg} \mathrm{Naton} \mathrm{out}$ & 18,0 & 18,0 & 18,0 & 18,0 & $-18,0$ \\
\hline N-FMN aplicado/ha & $\mathrm{kg} \mathrm{N} / \mathrm{hat}$ & 0,0 & 27,0 & 72,0 & 126,0 & 89,3 \\
\hline N-FMN TOTAL & tons $\mathrm{N}$-fert & 0 & 5989 & 75780 & 109902 & 191670 \\
\hline proporcäo N/FMN & tîertit N & 3,5548 & 3,5548 & 3,5548 & 3,5548 & \\
\hline fertizante & IFMN & 0 & 21288 & 269382 & 390678 & 681348 \\
\hline amóna & t amóniast FMN & 0.3875 & 0,3875 & 0,3875 & 0,3875 & \\
\hline amónia & tamonia & 0 & 8249 & 104386 & 151388 & 264022 \\
\hline energia & GJitamônia & 36,89 & 36,89 & 36,89 & 36,89 & \\
\hline energia & GJ total & 0 & 304309 & 3850781 & 5584697 & 9739787 \\
\hline produtividade & tha & 0,750 & 1,500 & 4,000 & 7,000 & 2,259 \\
\hline
\end{tabular}

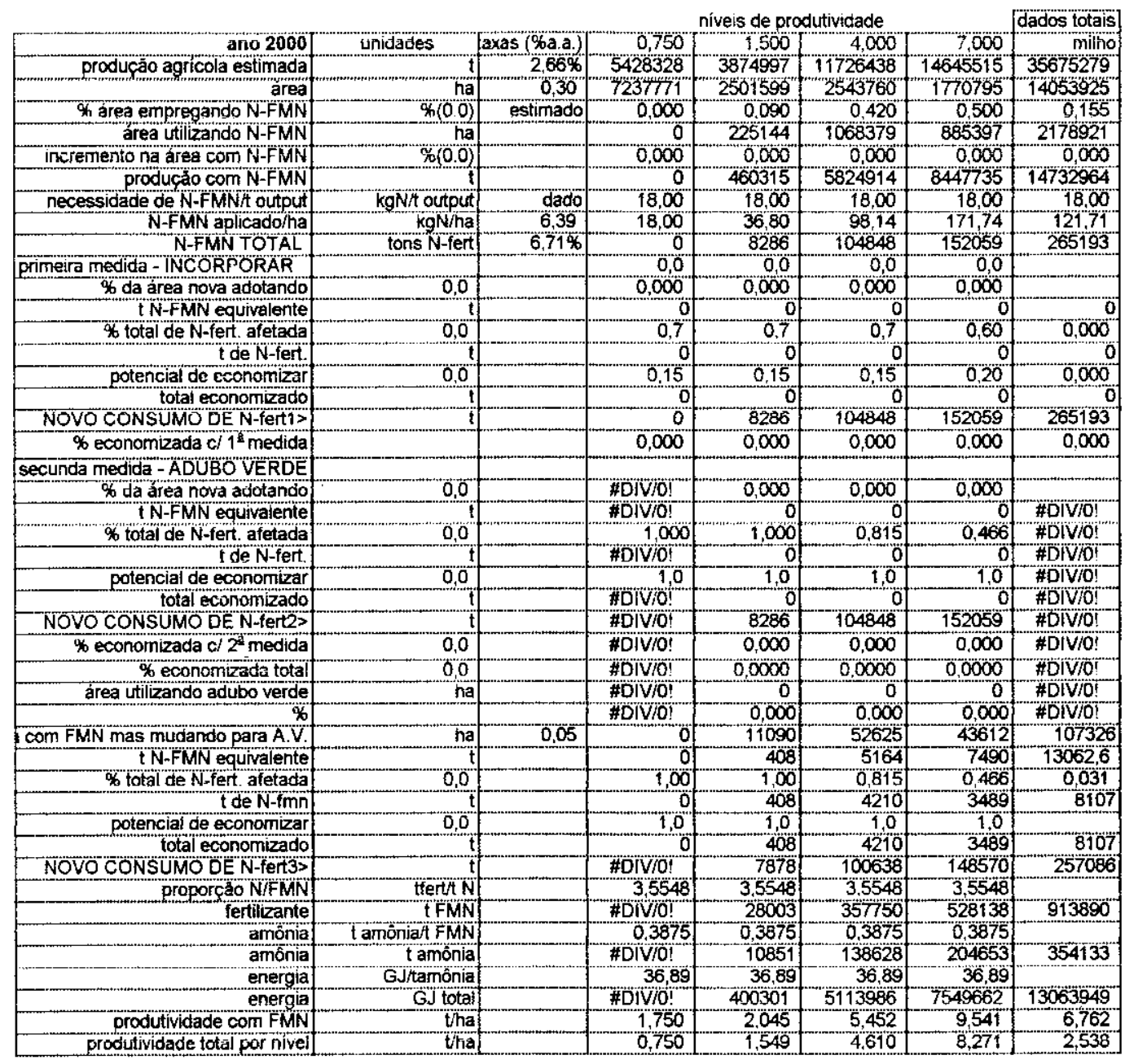




\begin{tabular}{|c|c|c|c|c|c|c|c|}
\hline & & & \multicolumn{4}{|c|}{ niveis de produtividade } & dados totais \\
\hline ano 2005 & unidades: & $a \times a s(\infty a-a)$ & 0,750 & 1,500 & 4,000 & 7,000 & millió \\
\hline producáo agricola estimada & tons & $3.14 \%$ & 5510243 & 4103100 & 14049897 & 17979543 & 41642783 \\
\hline area & hat & 0,30 & 7346991 & 2539348 & 2582146 & 1797516 & 14266002 \\
\hline \% area empregando $\mathrm{N}-\mathrm{FMN}$ & 0,0 & estimado & 0,000 & 0,090 & 0.420 & 0,500 & 0155 \\
\hline area utilizando N-FMN & ha & & 0 & 228541 & 1084501 & 898758 & 2211801 \\
\hline incremento na area com N-FMN & $\%(0.0)$ & & 0,000 & 0,000 & 0,000 & 0,000 & 0.000 \\
\hline producso cam N-FMN & t & & 0 & 636890 & 8059317 & 11688236 & 20384442 \\
\hline necessidadde de N-FMNAt output & $\mathrm{kgNt}$ output & dado & 18,00 & 18.00 & 18.00 & 18,00 & $-18,0$ \\
\hline N-FMN aplicado/ha & $\mathrm{kgN} / \mathrm{ha}$ & 6,39 & 2453 & 50,16 & 133,76 & 23409 & 165.89 \\
\hline NFMN TOTAL & tons $\mathrm{N}$-fert & $6,71 \%$ & 0 & 11464 & 145068 & 210388 & 366920 \\
\hline primeira medida - INCORPORAR & & & 0,00 & 0,00 & 0,00 & 0.00 & \\
\hline \% da area nova adotando & 0,0 & & 0,000 & 0,000 & 0,000 & 0,000 & \\
\hline IN-FMN equivalente & t & & 0 & of & of & 0 & 0 \\
\hline$\%$ total de $N$-fert afetada & 0.0 & & 0.7 & 0.7 & 0,7 & 0.6 & 0,000 \\
\hline ide N-fert & ti & & 0 & of & of & of & 0 \\
\hline potencial de economizar & 0,0 & & 0.15 & 0,15 & 0,15 & 0,20 & 0,000 \\
\hline total economizado & $t$ & & 0 & of & 0 & 0 & 0 \\
\hline NOVO CONSUMO DE N-fert $>$ & t) & & 0 & 11464 & 145068 & 210388 & 365320 \\
\hline$\%$ economizada ${ }^{\prime} ~^{1}$ medida & & & \#DIVIO! & 0.0000 & 0,0000 & 0,0000 & 0,0000 \\
\hline secunda medida - $A D U B O$ VERDE & & & & & & & \\
\hline \% da area nova adotandó & 0.0 & & HDivo! & 0,000 & 0,000 & 0,000 & \\
\hline IN-FMN equivaiente & t & & \#ÓIVIO! & of & of & of & \#DIVIO! \\
\hline$\%$ total de N-fert atetada & 0,0 & & 1,000 & 1,000 & 0,598 & 0,342 & \#DIVIO! \\
\hline tde N-fert & $t$ & & \#QIVIO! & 0 & 0 & 0 & \#LIVFi" \\
\hline potencial de economizar & 0,0 & & 1,0 & 1.0 & 10 & 10 & \\
\hline total economizado & if & & HDSVIO! & of & of & of & \#DIVIO! \\
\hline NOVO CONSUMO DE N-fert2> & t. & & \#D̈IVIO!! & 11464 & 145068 & 210388 & \#DIVIO! \\
\hline \% economizada $c / 2^{2}$ medida & 0,0 & & \#DIVIO! & 0,0000 & 0,0000 & 0,0000 & \#OIVIO! \\
\hline \% economzada total & 0,0 & & HDIVIO! & 0,0000 & 0.0000 & 0,0000 & HOIVIO' \\
\hline area utilizando adubo verde & ha & & "HOIVIO!" & 0 & 0 & 0 & \#DIVió" \\
\hline & & & \#OIVIO! & 0,0000 & 0.0000 & 0,0000 & \#DIVIO! \\
\hline com FMN mas mudando para A.V. & hat & 0,10 & $-\cdots$ & 22180 & 105250 & 87224 & 214653 \\
\hline t $N-F M N$ equivalente & it & & 0 & 1113 & 14079 & 20418 & 35609 \\
\hline \% total de $N$-fert afetada & 0,0 & & 10000 & 1,0000 & 0.5981 & 0,3418 & 0,045 \\
\hline tde N-fmn & t & & -1 & 1113 & 8420 & 6978 & 16510 \\
\hline potencial de economizar & 0.0 & & 1,0 & 1,0 & 1,0 & 1,0 & \\
\hline total economizado & t & & 0 & 1113 & 8420 & 6978 & 16510 \\
\hline NOVO CONSUMO DE N-fert3s & & & \#DIVIo! & 10351 & 136648 & 203410 & 350410 \\
\hline proporcáo N/FMN & tferte N & & 3,5548 & 3,5548 & 3,5548 & 3,5548 & \\
\hline fertitizante & $t F M N$ & & \#DIVio! & 36797 & 485755 & 723083 & 1245636 \\
\hline amónia & I amônia/ FMN & & 0,3875 & 0,3875 & 0,3875 & 0,3875 & \\
\hline amónia & tamônia & & \#DIVIo! & 14259 & 188230 & 280195 & 482684 \\
\hline energia & GJ/tamónia & & 36,89 & 36.89 & 36,89 & 36,89 & \\
\hline energia & G.J tota! & & \#DIVIO! & 526013 & 6943812 & 10336384 & 17806208 \\
\hline produtividade com FMN & $t / 4 a$ & & 2,113 & 2787 & 7,431 & 13,005 & 9216 \\
\hline produtividade total por nível & that & & 0,750 & 1,616 & 5,441 & 10,002 & 2919 \\
\hline
\end{tabular}

\begin{tabular}{|c|c|c|c|c|c|c|c|}
\hline & & & \multicolumn{4}{|c|}{ niveis de produtividade } & \multirow{2}{*}{ dados totais } \\
\hline ano 2010) & unidades & {$[a x a s$ (oxa.a. $]$} & 0.750 & 1,500 & 4,000 & 7,000 & \\
\hline producáo agricola estimada & tons & $1,78 \%$ & 5593394 & 4399713 & 17231803 & 18250859 & 45475770 \\
\hline area & ha & 0,30 & 7457859 & $25+7668$ & 2621112 & 1824641 & 14481280 \\
\hline \% área empregando N-FMN & 0,0 & estimado & 0,000 & 0,090 & 0,420 & 0.500 & 0,155 \\
\hline area utilizando N-FMN & nat & & 0 & 231990 & 1100867 & 912321 & 2245178 \\
\hline incremento na área com N-FMN & $\%(0.0)$ & & 0,000 & 0,000 & 0,000 & 0.000 & 0,000 \\
\hline productao com N-FMN & ti & & 0 & 881197 & 11150824 & 11864615 & 23896635 \\
\hline necessidade de N-FMNA output & $\mathrm{kgNh}$ output & dado & 18,00 & 18,00 & 18,00 & 18,00 & 18.00 \\
\hline N-FMN aplicadóha & $\mathrm{kgN} / \mathrm{ha}$ & 6,39 & 33,44 & 68,37 & 182,32 & 234,09 & 191.58 \\
\hline N-FMN TOTAL & tons $N$-fert & $3,23 \%$ & 0 & 15862 & 200715 & 213563 & 430139 \\
\hline primeira medida- NCORPORAR & & & 0,0 & 0.0 & 0,0 & 0.0 & \\
\hline \% da area nova adotando & 0.0 & & \#DIVIO! & 0,000 & 0,000 & 0,000 & \\
\hline IN-FMN equivaiente & tf & & \#DIVio! & of & of & 0 & \#DIVIO! \\
\hline$\%$ total de $N$-fert. afetada & 0,0 & & 0,7 & 0,7 & 0.7 & 0,6 & \#DIVIOO! \\
\hline tdeN-fert. & t & & HOIVIO! & of & of & 0 & \#DIVIO! \\
\hline potencial de economizar & 0,0 & & 0,15 & 0,15 & 0,15 & 0.20 & \#OIVIO! \\
\hline total economizado & t & & \#DIVIO! & of & of & - & \#DIVIO!' \\
\hline NOVO CONSUMO DE N-fert1> & it & & \#DIVIÓ! & 15862 & 200715 & 213563 & \#DIVIO! \\
\hline$\%$ economizada of $1 \%$ medida & & & \#DIV/o! & 0.000 & 0,000 & 0.000 & \#DIV/o! \\
\hline secunda medida - ADUBO VERDE & & & & & & & \\
\hline \% da área nova adotandó & 0,0 & & HDIVIO!" & 0,000 & 0,000 & 0,000 & \\
\hline tN-FMN equivalente & t & & \#DIVIO! & of & of & of & \#DIVIO! \\
\hline$\%$ total de $N$-fert. afetada & 0,0 & & 1,000 & 1,000 & 0,439 & 0,342 & \#DIVIO! \\
\hline tde N-fert & t & & \#DIVIO! & of & 0 & -1 & \#Divo! \\
\hline potencial de economizar & 0,0 & & 1,0 & 1,0 & 1,0 & 1,0 & \\
\hline total economizado & if & & \#ONOO! & of & of & of & \#DIVO! \\
\hline NOVO CONSUMO DE N-fert2> & t & & \#DIVIO? & 15862 & 200715 & 213563 & \#DIVIOI! \\
\hline$\%$ economizada $\alpha / 2^{2}$ medida & 0,0 & & \#DIVio! & 0,000 & 0,000 & 0,000 & \#DIVIo! \\
\hline \% economizada total & 0,0 & & HDIVIO! & 0,00 & 0,000 & 0.000 & \#DIVIO! \\
\hline área utilizando adubo verde & ha & & HDIVIo! & 0 & 0 & 0 & \#DIVIOI \\
\hline & & & \#OIVIO! & 0,0000 & 0,0000 & 0.0000 & \#DIVIÓ! \\
\hline com FMN mas mudando para $A V$. & hat & 0.15 & 0 & 33270 & 157875 & 130835 & 321979 \\
\hline TN-FMN equivalente & t & & of & 2275 & 28784 & 30627 & 61686 \\
\hline \% total de N-fert afetada & 0,0 & & 1,0000 & 1,0000 & 0,4388 & 0,3418 & 0,059 \\
\hline t de N-fmnt & it & & 0 & 2275 & 12630 & 10467 & 25371 \\
\hline potencial de economizar & 0.0 & & 1,0 & 1,0 & 1,0 & 1,0 & \\
\hline total economizado & tit & & of & 2275 & 12630 & 10467 & 25371 \\
\hline NOVO CONSUMO DE N-fert $3>$ & t & & \#DIVÍ!" & 13587 & 188085 & 203096 & 404768 \\
\hline proporcáo N/FMN & tfertt N & & 3,5548 & 3.5548 & 3,5548 & 3.5548 & \\
\hline fertilizante & $t F M N$ & & \#DIVIO! ! & 48299 & 668604 & 721967 & 1438869 \\
\hline amônia & t amôniat FMN & & 0,3875 & 0,3875 & 0,3875 & 0.3875 & \\
\hline amónia & tamônia & & \#DIVio! & 18716 & 259084 & 279762 & 557562 \\
\hline energia & Gj/tamônia & & 36,89 & 36,89 & 36,89 & 36,89 & \\
\hline energia & GJ total & & \#DIVIÓ! & 690421 & 9557612 & 10320421 & 20563454 \\
\hline produtividade com FMN & tha & & 2,608 & 3,798 & 10,129 & 13,065 & 10,64 \\
\hline produtividade total por nivel & & & 0,750 & 1,707 & 6.574 & 10,002 & 3140 \\
\hline
\end{tabular}


CENÁRIO SIMULTÂNEO I

\begin{tabular}{|c|c|c|c|c|c|c|}
\hline \multirow{3}{*}{ ano-base: 1995} & \multicolumn{6}{|c|}{ proporçåo por nivel de produtividade } \\
\hline & & 0,5150 & 0.1780 & 0.1810 & 0,1260 & dados totais \\
\hline & niveis de produt & 0,750 & 1,500 & 4.000 & 7,000 & mitho \\
\hline & unidades & & & & & \\
\hline producăo agricola & $1000 \mathrm{t}$ & 5347631 & 3696615 & 10023780 & 12211290 & 31279316 \\
\hline area & ha & 7130175 & 2464410 & 2505945 & 1744470 & 13845000 \\
\hline produtividade & tina & 0,750 & 1,500 & 4,000 & 7,000 & 2,259 \\
\hline$\%$ area empregando N-FMN & 0 & 0,00 & 0,090 & 0.42 & 0.50 & 0,16 \\
\hline area utilizando N-FMN & ha & 0 & 221797 & 1052497 & 872235 & 2146529 \\
\hline producáo com N-FMN & $\mathrm{t}$ & 0,0 & 332695 & 4209988 & 6105645 & 10648328 \\
\hline ecessidadde de N-FMNAt output & $\mathrm{kg} \mathrm{N} /$ ton out & 18,0 & 18,0 & 18,0 & 18,0 & 18,0 \\
\hline N-FMN aplicadoha & $\mathrm{kg} \mathrm{Nha}$ & 0,0 & 27,0 & 72,0 & 126,0 & 89,3 \\
\hline N-FMN TOTAL & tons $\mathrm{N}$-fert & 0 & 5989 & 75780 & 109902 & 191670 \\
\hline proporcao N/FMN & tfertit N & 3,5548 & 3.5548 & 3.5548 & 3,5548 & \\
\hline fertilizante & $t F M N$ & 0 & 21288 & 269382 & 390678 & 681348 \\
\hline amónia & tamônial FMN & 0,3875 & 0,3875 & 0.3875 & 0.3875 & \\
\hline amôniz & tamônia & 0 & 8249 & 104386 & 151388 & 264022 \\
\hline energia & GJifamônia & 36.89 & 36,89 & 36,89 & 36,89 & \\
\hline energia & GJ tótal & 0 & 304309 & 3850781 & 5584697 & 9739787 \\
\hline produtividade & tha & 0,750 & 1,500 & 4,000 & 7,000 & 2,259 \\
\hline
\end{tabular}

\begin{tabular}{|c|c|c|c|c|c|c|c|}
\hline & & & \multicolumn{4}{|c|}{ niveis de produtividade } & dados totais \\
\hline ano 2000 & unidades & axas $(\% a . a)$ & 0,750 & 1,500 & 4,000 & 7.000 & milho \\
\hline produço agricola estimada & (1) & $2,66 \%$ & 5428328 & 3874997 & 11726438 & 14645515 & 35675279 \\
\hline area & ha & 0,30 & 7234771 & 2501599 & 2543760 & 1770795 & 14053925 \\
\hline \% area empregando N-FMN & $\%(0.0)$ & estimado & 0,000 & 0.090 & 0,420 & 0.500 & 0,155 \\
\hline area utilizando N-FMN & na & & 0 & 225144 & 1068379 & 885397 & 2178921 \\
\hline incremento na area com $\mathrm{N}$-FMN & $\%(00)$ & & 0,000 & 0,000 & 0,000 & 0,000 & 0,000 \\
\hline producto com N-FMN & $t$ & & 0 & 460315 & 5824914 & 8447735 & 14732964 \\
\hline necessidade de N-FMNA output & $\mathrm{kgNA}$ output & dado & 18,00 & 18,00 & 1800 & 18.00 & 18,00 \\
\hline N-FMN aplicadoina & $\mathrm{kgN} / \mathrm{ha}$ & 6,39 & 18,00 & 36,80 & 98,14 & 171,74 & 121,71 \\
\hline N-FMNTOTAL & tons $\mathrm{N}$-fert & $6,71 \%$ & 0 & 8286 & 104848 & 152059 & 265193 \\
\hline primeira medida - INCORPORAF & & & 0,5 & 0,5 & 0,5 & -0.5 & \\
\hline \% da área nova adotando & 0,0 & & \#Divio! & 0,000 & 0,000 & 0,000 & \\
\hline IN-FMN equivalente & t & & \#DIV/O! & 0 & of & of & \#DIVIOI \\
\hline$\%$ total de $N$-fert afetada & 0,0 & & 0,7 & 0,7 & 0,7 & 0,60 & \#DIVIO! \\
\hline tde N-fert. & if & & \#DIVio! & of & of & 0 & \#DIVIOI'] \\
\hline potencial de economizar & 0,0 & & 0,15 & 0,15 & 0,15 & 0.20 & \#DEVIO! \\
\hline total economizado & $t$ & & \#DIVio! & 0 & of & 0 & \#DIVIO! \\
\hline NOVO CONSUMO DE N-fert $1>$ & $t$ & & \#DIVIO! & 8286 & 104848 & 152059 & \#DIVIO! \\
\hline$\%$ economizada ol 1 medida & & & \#DIVIO! & 0.000 & 0,000 & 0,000 & \#DIVIO! \\
\hline Unda medida - ADUBO VERDE & & & & & & & \\
\hline \% da artea nova adotando & 0,0 & & FDIVO" & 0,000 & 0,000 & 0,000 & \\
\hline I N-FMN equivaiente & tit & & HDIVio! & of & of & 0 & \#DIVIO! \\
\hline \% total de N-fert afetada & 0,0 & & 1,000 & $1,0,0$ & 0,815 & 0.466 & \#DIVio! \\
\hline tde N-fert & it & & \#DIVIO!! & 0 & 0 & o & \#DIV/O! \\
\hline potencial de economizar & 0,0 & & 1,0 & 10 & 1.0 & 1,0 & \#DIVIO! \\
\hline total economizado & if & & \#Divio! & 0 & 0 & 0 & \#DIVIO! \\
\hline NOVO CONSUMO DE N-fert2> & if & & \#DIVIO! & 8286 & 104848 & 152059 & \#DIVIO! \\
\hline$\%$ economizada c/ $2^{3}$ medida & 0,0 & & \#DIV/O! & 0,000 & 0,000 & 0,000 & \#DIVIo! \\
\hline \% economizada total & 0,0 & & \#DIVIO! & 0.0000 & 0,0000 & 0,0000 & \#DIVIO! \\
\hline area utilizando adubo verde & hat & & \#Divio! & 0 & 0 & 0 & "\#DIVIOI" \\
\hline & & & \#DOViol & 0.000 & 0.000 & 0,000 & \#DIVIO! \\
\hline INCORPORAR & 0.05 ha & 0,03 & of & 5545 & 26312 & 21806 & 53663 \\
\hline IN-FMN equivalente & t & & 0 & 204 & 2582 & 3745 & 6531,3 \\
\hline * total de N-fert afetada & 0,0 & & 0,70 & 0,70 & 0,70 & 0,60 & 0,016 \\
\hline tdeN-fmn & t & & 0 & 143 & 1808 & 2247 & 4197 \\
\hline potencial de economizar & 0,0 & & 0,15 & 0,15 & 0,15 & 0.21 & \\
\hline total economizado & t & & 0 & 21 & 271 & 449 & 742 \\
\hline NOVO CONSUMO DE N-fert $3>$ & t & & \#Divio! & 8264 & 104577 & 151610 & \#DIVio! \\
\hline ADUBO VERDE & hat & 0,03 & 0 & 5545 & 26312 & 21806 & 53663 \\
\hline iN-FMN equivalente & t & & 0 & 204 & 2582 & 3745 & 6531 \\
\hline$\%$ total de N-fert afetada & 0,0 & & 1,000 & 1,000 & 0,815 & 0,466 & \\
\hline tde N-fmn & t & & -0 & 204 & 2105 & 1744 & 4054 \\
\hline potencial de ecoromizar & 0,0 & & 1,0 & 1,0 & 1,0 & $-1,0$ & \\
\hline total economizado & t & & -0 & 204 & 2105 & 1744 & 4054 \\
\hline NOVO CONSUMO DE N-fert $4>$ & $\mathrm{t}$ & & \#DIVIO! & 8060 & 102472 & 149865 & \#DIVIO! \\
\hline proporcão NiFMN & tfertt N & & 3,5546 & 3,5548 & 3,5546 & 3.546 & \\
\hline fertilizante & $t F M N$ & & ADIVIO! & 28652 & 364269 & 532741 & \#DINO! \\
\hline amónia & t amoniat $F M N$ & & 0,3875 & 0,3875 & 0.3875 & 0,3875 & \\
\hline amónia & tamónia & & \#Divio! & 11103 & 141154 & 206437 & \#DIVIO! \\
\hline energia & GJ/tamônia & & 36,89 & $-36,89$ & 36.89 & 36,89 & \\
\hline energia & GJ total & & \#DIVÓ! & 409582 & 5207974 & 7615471 & ADIVIO! \\
\hline produtividade com FMN & that & & 1,750 & 2,045 & 5,452 & 9,541 & 6,762 \\
\hline produtividade total por nivel & tha & & 0,750 & 1,549 & 4,610 & 8.271 & 2,538 \\
\hline
\end{tabular}




\begin{tabular}{|c|c|c|c|c|c|c|c|}
\hline & & & \multicolumn{4}{|c|}{ niveis de produtividade } & dados totais \\
\hline ano 2005 & unidades & {$[a x a s(\% a \cdot a)]$} & 0,750 & 1.500 & 4,000 & 7,000 & millio \\
\hline produçáo agricola estimada & tons & $3.14 \%$ & 5510243 & 4103100 & 14049897 & 17979543 & 41642783 \\
\hline area & ha & $0.30^{\circ}$ & 7346991 & 2539348 & 2582146 & 1797516 & 14266002 \\
\hline \% area empregando N-FMN & 0,0 & estimado & 0,000 & 0,090 & 0,420 & 0,500 & 0,155 \\
\hline area utilizando N-FMN & ha & & 0 & 228541 & 1084501 & 898758 & 2211801 \\
\hline ncremento na área com N-FMN & $\%(0.0)$ & & 0,000 & 0,000 & 0,000 & 0,000 & 0,000 \\
\hline producăo com N-FMN & $t$ & & 0 & 636890 & 8059317 & 11688236 & 20384442 \\
\hline necessidade de N-FMN/t output & $\mathrm{kgNAt}$ output & dado & 18,00 & 18,00 & 18,00 & 18,00 & 18,00 \\
\hline N-FMN aplicado/ha & $\mathrm{kgN} / \mathrm{ha}$ & 6.39 & 24,53 & 50,16 & 133,76 & 234,09 & 165.89 \\
\hline N-FMNTOTAL & tons N-fert & $6,71 \%$ & 0 & 11464 & 145068 & 210388 & 366920 \\
\hline primeira medida - INCORPORAR & & & 0,50 & 0,50 & 0,50 & 0,50 & \\
\hline \% da area nova adotando & 0,0 & & \#DIVIO! & 0,000 & 0.000 & 0.000 & \\
\hline T N-FMN equivalente & t & & \#DIVIO! & 0 & 0 & 0 & \#DIVIO! \\
\hline \% total de $N$-fert afetada & 0,0 & & 0,7 & 0,7 & 0.7 & 0.6 & \#DOVIÓ? \\
\hline tdeN-fert & $t$ & & \#DIVIÓ & of & of & 0 & \#DIVIOT! \\
\hline potencial de economizar & 0,0 & & 0,15 & 0,15 & 0,15 & 0,20 & \#D̈VIÓ! \\
\hline total economizado & $t$ & & \#DIVIO! & 0 & 0 & 0 & \#DIVIÓ! \\
\hline NOVO CONSUMO DE N-fert $1>$ & t) & & \#DIVIO! & 11464 & 145068 & 210388 & \#DIV/O! \\
\hline$\%$ economizada c/ 1 medida & & & \#DIVIO! & 0,0000 & 0,0000 & 0,0000 & \#DIVIO! \\
\hline Unda medida - ADUUBO VEROE & & & & & & & \\
\hline \% da area nova adulando & 0,0 & & HDNOO! & 0,000 & 0,000 & 0.000 & \\
\hline t N-FMN equivalente & if & & \#DIVIÓ! & of & of & 0 & \#DivOO! \\
\hline$\%$ total de N-fert afetada & 0,0 & & 1,000 & 1,000 & 0.598 & 0,342 & \#DIVIÓ! \\
\hline tdeN-fert & t & & \#DIVIÓ! & of & 0 & 0 & \#DIVOT! \\
\hline potencial de economizar & 0,0 & & 1,0 & 1,0 & 1.0 & 1.0 & \\
\hline total economizado & t) & & \#Divio! & of & 0 & 0 & HDivio! \\
\hline NOVO CONSUMO DE N-fert $2>$ & it & & \#DIVIÓ! & 11464 & 145068 & 210388 & \#DIVIO! \\
\hline \% economizada o/ 2 medida & 0,0 & & \#DIVIO! & 0,0000 & 0,0000 & 0.0000 & \#DIVIO! \\
\hline \% economizada total & 0.0 & & "HDIVIO! & 0,0000 & 0,0000 & 0,0000 & \#DIVIO! \\
\hline area utilizando adubo verde & hat & & HDIVIO! & 0 & 0 & 0 & \#Divio! \\
\hline$\%$ & & & \#DIVIo! & 0,0000 & 0,0000 & 0.0000 & \#DIVIO! \\
\hline INCORPORAR & $0.10 \mathrm{hat}$ & 0,05 & of & 11090 & 52625 & 43612 & 107326 \\
\hline TN-FMN equivalente & $t$ & & of & 556 & 7039 & 10209 & 17805 \\
\hline \% total de N-fert afetada & 0.0 & & 0,7000 & 0,7000 & 0,7000 & 0.3000 & 0,023 \\
\hline t de N-fmn & if & & of & 389 & 4928 & 3063 & 8380 \\
\hline potencial de economizar & 0,0 & & 0,15 & 0,15 & 0,15 & 0.2 & \\
\hline total economizadol & $t$ & & Of & 58 & 739 & 613 & 1410 \\
\hline NOVO CONSUUMO DE N-fert $3>$ & if & & HDIVIO! & 11406 & 144329 & 209776 & \#DIVIO! \\
\hline ADUBO VEROEE & hat & 0,05 & 0 & 11090 & 52625 & 43612 & \\
\hline t N-FMN equivalente & t & & 0 & 556 & 7039 & 10209 & 17805 \\
\hline \% total de N-fert afelada & 0.0 & & 1,000 & 1,000 & 0,598 & 0,342 & \\
\hline tde N-fmn & if & & 0 & 556 & 4210 & 3489 & 8255 \\
\hline potencial de economizar & 0,01 & & 1,0 & 1,0 & 1,0 & 1,0 & \\
\hline total economizado & t & & 0 & 556 & 4210 & 3489 & 8255 \\
\hline NOVO CONSUMO DE N-fert4 & $t$ & & \#DIVIO! & 10849 & 140119 & 206287 & \#OIVIO! \\
\hline proporcäo N/FMN & iferti N & & 3,5548 & 3,5548 & 3,554 & 3.5548 & \\
\hline fertitizante & $T F M N$ & & \#Divio! & 38567 & 498094 & 733308 & \#DIVIO! \\
\hline amoria & t amoniat FMN & & 0,3875 & 0,3875 & 0,3875 & 0,3875 & \\
\hline amónia & tamônia & & \#DIV/O! & 14945 & 193011 & 284157 & \#DIVIV! \\
\hline energia & GJitamônia & & 36,89 & 36,89 & 36,89 & 36,89 & \\
\hline energia & GJ total & & \#DIVIÓ! & 551313 & 7120185 & 10482549 & \#DIVIO! \\
\hline produtividade com FMN & t/ha & & 2,113 & 2,787 & 7,431 & 13,005 & 9,216 \\
\hline produtividade total por nivel & that & & 0,750 & 1,616 & 5,441 & 10,002 & 2919 \\
\hline
\end{tabular}




\begin{tabular}{|c|c|c|c|c|c|c|c|}
\hline & & & \multicolumn{4}{|c|}{ niveis de produtividade } & dados totais \\
\hline ano 2010 & unidades: & [axas (\%a a.) & 0,750 & 1,500 & 4,000 & 7,000 & mithö \\
\hline produçâo agricola estimada & tons & $1,78 \%$ & 5593394 & 4399713 & 17231803 & 18250859 & 45475770 \\
\hline $\begin{array}{r}\text { area } \\
\text { a }\end{array}$ & hal & 0.30 & 7457859 & 2577668 & 2621112 & 1824641 & 14481280 \\
\hline$\%$ area empregando $N-F M N$ & 00 & estimado & 0,000 & $-0,090$ & -0420 & 0,500 & 0.155 \\
\hline area utitizando N-FMN & ha & & 0 & 231990 & 1100867 & 912321 & 2245178 \\
\hline incremento na área com N-FMN & $\%(0.0)$ & & 0,000 & 0,000 & $0,000^{\circ}$ & $0.000^{\circ}$ & 0,000 \\
\hline producáo com N-FMN & $t$ & & 0 & 881197 & 11150824 & 11864615 & 23896635 \\
\hline necessidade de N-FMNit output & $\mathrm{kgNA}$ output & dado & 18,00 & 18,00 & 18,00 & $-18,00$ & 18,00 \\
\hline N-FMN apilicadolta & $\mathrm{kgN/ha}$ & 6,39 & 33,44 & 68.37 & 182,32 & 234,09 & 191.58 \\
\hline N-FMN TOTAL & tons $\mathrm{N}$-fert & $3,23 \%$ & 0 & 15862 & 200715 & 213563 & 430139 \\
\hline primeira medida - INNCORPORA & & & 0,5 & 0,5 & 0.5 & 0.5 & \\
\hline \% da area nova adotando & 0,0 & & \#OIV/O! & 0,000 & 0,000 & 0,000 & \\
\hline IN-FMN equivalente & $t$ & & \#OIV70! & 0 & of & 0 & \#DIVIO!! \\
\hline \% totat de N-fert afetada & 0,0 & & 0,7 & 0,7 & 0,7 & 0,6 & \#OIVIO!! \\
\hline t de N-fert & t & if & \#DIVIO! & of & 0 & 0 & \#DIVIO! \\
\hline potenciai de economizar & 0,0 & & 0,15 & 0.15 & 0,15 & 0,20 & \#DIVIO! \\
\hline total economizado & tit & & \#DIVIO! & 0 & of & 0 & \#DIVIO! \\
\hline NOVO CONSUMO OE N-fert $1>$ & $\mathrm{t}$ & & \#DIVIO! & 15862 & 200715 & 213563 & \#UIVio! \\
\hline$\%$ economizada c/ $1{ }^{9}$ medida & & & \#Divio! & 0.000 & 0,000 & 0,000 & \#DIVIO! \\
\hline Unda medida - ADUBO VERDE & & & & & & & \\
\hline \% da área nova ádótando & 0,0 & & WDIVOI! & 0,000 & 0,000 & 0,000 & \\
\hline$t N-F M N$ equivalente & tf & & \#DIVIO! & of & of & 0 & \#OIVIO! \\
\hline \% total de $\mathrm{N}$-fert. afetada & 0,0 & & 1,000 & 1,000 & 0,439 & 0,342 & "HOIVIO! \\
\hline de N-fert & t & & \#DIVRo! & of & 0 & 0 & \#DIV 0 ! \\
\hline potencial de economizat & 0.0 & & 1,0 & 1.0 & 1,0 & 1,0 & \\
\hline total economizado & $t$ & & \#DIVIO! & 0 & 0 & 0 & ADIVIO! \\
\hline NOVO CONSUMO DE N-fert2? & it & & "oivor & 15862 & 200715 & 213563 & \#DIVIO! \\
\hline \% economizada $\mathrm{c} / 2^{2}$ medida & 0,0 & & \#DIVIO! & 0,000 & $0,000^{\circ}$ & 0,000 & \#OIV/O! \\
\hline$\%$ economizada totai & 0,0 & & \#DIVIO! & 0,000 & 0,000 & 0,000 & "OOIVIO! \\
\hline area utilizando adubo verde & ha & & \#DIVIo! & 0 & 0 & 0 & \#DIVIO! \\
\hline$\%$ & & & \#DIVIO! & 0.0000 & 0.0000 & 0,0000 & \#Divio! \\
\hline INCORPORAR & hat & 0.08 & 0 & 16635 & 78937 & 65418 & 160990 \\
\hline IN-FMN equivalente & t & & of & 1137 & 14392 & 15313 & 30843 \\
\hline \% total de Nofert afelada & 0,0 & & 0,7000 & 0.7000 & 0,3500 & 0,2400 & 0,022 \\
\hline t de N-fmn & t & & 0 & 796 & 5037 & 3675 & 9509 \\
\hline potencial de economizar & 0,0 & & 0,15 & 0,15 & 0.15 & 0,2 & \\
\hline total economizado & t & & 0 & 119 & 756 & 735 & 1610 \\
\hline NOVO CONSUMO DE N-fert $3>$ & th & & \#DIVIO! & 15742 & 199959 & 212828 & \#DIVIO! \\
\hline ADUBO VERDE & na & 0,08 & 0 & 16635 & 78937 & 65418 & \\
\hline t N-FMN equivalentè & t & & 0 & 1137 & 14392 & 15313 & 30843 \\
\hline \% total de N-fert afeiada & 0,0 & & 1,000 & 1,000 & 0,439 & 0,342 & \\
\hline toe N-fmn & if & & 0 & 1137 & 6315 & 5233 & 12686 \\
\hline potencial de economizar & 0,0 & & 1,0 & 1,0 & 1,0 & 1,0 & \\
\hline total ecomonizado & & & -0 & 1137 & 6315 & 5233 & 12686 \\
\hline NOVO CONSUMO DE N-fert $4>$ & t & & \#DIV/O! & 14605 & 193644 & 207595 & \#DIVIOI \\
\hline prooorc $\$ 0 \mathrm{~N} / \mathrm{FMN}$ & tfertit N & & 3,5548 & 3,5548 & 3.5548 & 3,5548 & \\
\hline fertitizante & TFMN & & \#OIVIO! & 51917 & 688367 & 737957 & \#DIVIO! \\
\hline amónia & tamoniat FMN & & 0,3875 & 0,3875 & 0,3875 & 0.3875 & \\
\hline amônia & t amônia & & \#DIVIO! & 20118 & 266742 & 285958 & \#DIVIOI \\
\hline energia & GJitamónia & & 36,89 & 36,89 & 36,89 & 36,89 & \\
\hline energia & $\mathrm{G}$ s total & & \#DIVIO! & 742148 & 3840114 & 10549007 & \#DIVIO! \\
\hline produtividade com FMN & tha & & 2,608 & 3,798 & 10,129 & 13,005 & 10,644 \\
\hline produtividade total por nivei & & & 0,750 & 1,707 & 6,574 & 10,002 & 3,140 \\
\hline
\end{tabular}


CENÁRIO REFERÉNCIA ॥

\begin{tabular}{|c|c|c|c|c|c|c|c|}
\hline & \multicolumn{7}{|c|}{ proporção por nivel de produtividade } \\
\hline ano-tase: 1995 & & 0,5150 & 0.1780 & 0.1810 & 0,1260 & & dados totais \\
\hline & niveis de produt & 0,750 & 1,500 & 4,000 & 7,000 & & milno \\
\hline & unidaces & & & & & & \\
\hline producăo agricola & $1000 \mathrm{t}$ & 5347631 & 3696615 & $10023780^{\circ}$ & $12211290^{\circ}$ & & 31279316 \\
\hline area & ha & 7130175 & 2464410 & 2505945 & 1744470 & & 13845000 \\
\hline produtividade & tha & 0.750 & 1,500 & 4,000 & 7,000 & & 2,259 \\
\hline$\%$ area empregando $\mathrm{N}-\mathrm{FM}$ & 0,0 & 0,00 & $0.090^{\circ}$ & 0.42 & 0.50 & & 0,16 \\
\hline área utilizando N-FMN & ha & 0 & 221797 & 1052497 & 872235 & & 2146529 \\
\hline produca o com N-FNN & t & 0,0 & 332695 & 4209988 & 6105645 & & 10048328 \\
\hline recessidado de N-FMNAt output & $\mathrm{kg} N / t \mathrm{ton}$ out & 180 & 180 & 180 & 18,0 & & 180 \\
\hline N-FMN aplicadolha & kg N/ha & 0,0 & 27,0 & 72,0 & 1260 & & 89,3 \\
\hline N-FMN SOTAL & tons N-fert & o' & 5909 & 7580 & 109902 & & 191670 \\
\hline proporcäo NIFAN & fertit N & 3,5548 & 35548 & 3.5548 & 3,5548 & & \\
\hline fertizante & tFMN & 0 & 21288 & 269382 & 390678 & & 681348 \\
\hline amónia & tamônia't FMN & 0,3875 & 0,3875 & 0,3075 & 0,3875 & & \\
\hline amônia & tamônia & 0 & 8249 & 104386 & 151388 & & 264022 \\
\hline energia & GjJtamónia & 3689 & 36,89 & 36,89 & 36.89 & & \\
\hline energia & GJ total & 0 & 304309 & 3950791 & 5584697 & & 9739787 \\
\hline produtividade & tha & 0,750 & 1.500 & 4,000 & 7,000 & & 2.259 \\
\hline
\end{tabular}

\begin{tabular}{|c|c|c|c|c|c|c|c|}
\hline \multirow{3}{*}{ ano 2000} & \multicolumn{6}{|c|}{ niveis de produtividade } & \multirow{2}{*}{$\begin{array}{r}\text { dados totais } \\
\text { milno }\end{array}$} \\
\hline & unjdades & $\left.\operatorname{taxas}\left(\% a a_{0}\right)\right]$ & 0,750 & 1,500 & 4,000 & 7,000 & \\
\hline & $t$ & $3,80 \%$ & 5790217 & 3956730 & 12391322 & 15545497 & 37683767 \\
\hline area & ha & 0,30 & 7237771 & 2501599 & 2543760 & 1770795 & 14053925 \\
\hline \% area empregando $\mathrm{N}-\mathrm{F} M \mathrm{~N}$ & $\%(0.0)$ & Estiriado & 0,05 & 0,150 & 0,60 & 0,70 & 0,249 \\
\hline area utilizando $N-F M N$ & ha & & 361889 & 375240 & 1526256 & 1239556 & 3502941 \\
\hline incremento na area com N-FF MN & $\%(0.0)$ & & 0.050 & 0,060 & 0,180 & $0,200^{\circ}$ & 0,094 \\
\hline producaocom N-FMN & t. & & 633305 & 767192 & 8321306 & 11826828 & 21548531 \\
\hline necessidade de N-FMN/t output & $\mathrm{kgN/t}$ outputt & dado] & 18,00 & 18,00 & 18,00 & 18,00 & 15,00 \\
\hline N-FMN aplicadoha & $\mathrm{kgN} / \mathrm{ha}$ & 6,39 & 18 & 37 & ")"'"98" & 172 & 109.33 \\
\hline N-FMNAOTAL & tons $\mathrm{N}$-fert & $14.85 \%$ & 6514 & 13809 & 149784 & 212883 & 382990 \\
\hline proporcâo N/FMN & tertert N & & 3,5548 & 3.5548 & 3,5548 & 3,5548 & \\
\hline fertilizante & $+F M N$ & & 23156 & 49090 & 532450 & 756756 & 1361452 \\
\hline amônia & t amóniatt FMN & & 0,3875 & 03875 & 0,3875 & 0,3875 & \\
\hline amônia & tamónia & & 8973 & 19022 & 206325 & 293243 & 527563 \\
\hline energia & Gjftamónia & & 38,89 & 36,89 & 3689 & 36,89 & \\
\hline energia & G total & & 331011 & 701734 & 7611312 & 10817735 & 19461792 \\
\hline produtividade com FMN & tha & & 1,750 & 2,045 & 5,452 & 9,541 & 6,152 \\
\hline produtividade total por nivel & & & 0,800 & 1,582 & 4.871 & 8,779 & 2.681 \\
\hline
\end{tabular}

\begin{tabular}{|c|c|c|c|c|c|c|c|}
\hline & & & \multicolumn{4}{|c|}{ niveis de produtividade } & dados totais \\
\hline ano 2005 & unidades & taxas (\%a.a.)] & 0,750 & 1,500 & 4,000 & 7.000 & mitho \\
\hline producäo agricola estimadä & . & $5,56 \%$ & 7012364 & 4625905 & 16530771 & 21217700 & 49386740 \\
\hline area & ha & 0,30 & 7346991 & 2539348 & 2582146 & 1797516 & 14266002 \\
\hline$\%$ area empregando N-FMN & $\%(0.0)$ & estimado & 0,150 & $0.250^{\circ}$ & 0,700 & 0,800 & 0,349 \\
\hline area utilizando N-FMN & hat & & 1102049 & 634837 & 1807502 & 1438013 & 4982401 \\
\hline incremento na area com N-FMN & $\%(0.0)$ & & 0.100 & 0,100 & 0100 & 0,100 & 0,100 \\
\hline produsao com N-FMN & t. & & 2328657 & 1769138 & 13432195 & 18701177 & 36231167 \\
\hline necessidade de N-F MN/t output & $\mathrm{kgNit}$ output & dado & 18,00 & 18,00 & 18,00 & 18,00 & 18,00 \\
\hline N-FMN aplicadoha & $\mathrm{kgN} / \mathrm{ha}$ & 639 & 25 & 50 & 134 & 234 & 127,91 \\
\hline N-FMN TOTAL & tons N-fert & $10,72 \%$ & 27038 & 31844 & 241780 & 336621 & 637283 \\
\hline proporcáo NiFMN & tfertit N & & 3,5548 & 3.5548 & 3,5548 & 3,5548 & \\
\hline fertilizante & $t F M N$ & & 96115 & 113201 & 859478 & 1196621 & 2265415 \\
\hline amônia & t amônia/t FMN & & 0.3875 & 0,3875 & 0.3875 & 0,3875 & \\
\hline amónia & t amonia & & 37245 & 43865 & 333048 & 463691 & 877848 \\
\hline energia & Giramôniat & & 36,89 & $3 \times 3,89$ & 36,89 & 36,89 & \\
\hline energia & Gij total & & 1373956 & 1618191 & 12286128 & 17105548 & 32383822 \\
\hline produtividade com FiMN & that & & 2,113 & 2,787 & 7,431 & 13,005 & 7,272 \\
\hline produtividade total por nivel & that & & 0.054 & 1.822 & 6,402 & 11.804 & 3,462 \\
\hline
\end{tabular}

\begin{tabular}{|c|c|c|c|c|c|c|c|}
\hline & & & \multicolumn{4}{|c|}{ níveis de produtividade } & dados totais \\
\hline ano 2010 & unidades & taxas (\%a.a.) & 0750 & 1,500 & 4,000 & 77,000 & millso \\
\hline producăo agrícola estomadä & …………… & $5,03 \%$ & 9057270 & 5940102 & 24943067 & 23181392 & 63121831 \\
\hline area & hä & 0,30 & 7457859 & 2577668 & 2621112 & 1824641 & $14481280^{\circ}$ \\
\hline$\%$ area empregando $\mathrm{N}-\mathrm{FMN}$ & $\%(0.0)$ & estimado & 0,250 & 0,350 & 0,900 & 0.950 & 0.474 \\
\hline área utilizando $\mathrm{N}-\mathrm{FMN}$ & ha & & 1864465 & 902184 & 2359001 & 1733409 & 6859058 \\
\hline incremento na área com N-FMN & $\%(0.0)$ & & 0,100 & 0.100 & 0.200 & 0,150 & 0,124 \\
\hline produca o com N-FMN & t & & 4862224 & 3426876 & 23894622 & 22542768 & 54726490 \\
\hline necessidade de N-FMNN/t output & $\mathrm{kgNAt}$ output & dado & 18,00 & 18,00 & 18,00 & 18,00 & 18,00 \\
\hline$N F M N$ aphicado $h a$ & kgN/ha & 6,39 & 33 & 68 & 182 & 234,09 & 139.95 \\
\hline N-FMN TOTAL & tons N-fert & $8.54 \%$ & $62350^{\circ}$ & 61684 & 430103 & 405770 & 959907 \\
\hline proporçao N/FMN & thertit N & & 3.5548 & 3.5548 & 3,5548 & 3,5548 & \\
\hline fertlizante & $t F M N$ & & 221641 & 219273 & 1528931 & 1442431 & 3412276 \\
\hline amônia & tamóniart FMN & & 0,3875 & 0,3875 & 0,3875 & 0,3875 & \\
\hline amôniá & tamóniá & & 85886 & 84968 & 592461 & 558942 & 1322257 \\
\hline energia & Gijtamônia & & 36,89 & 36.89 & 36.89 & 36.89 & \\
\hline energia & GJ total & & 3168329 & 3134487 & 21855875 & 20619364 & 48778056 \\
\hline produtividade com FMN & tha & & 2,608 & 3798 & 10,129 & 13,005 & 7979 \\
\hline produtividade total por nivei & titha & & 1,214 & 2,304 & 9516 & 12,705 & 4359 \\
\hline
\end{tabular}


CENÁRIO MANEJO EFICIENTE ॥

\begin{tabular}{|c|c|c|c|c|c|c|}
\hline \multirow{3}{*}{ ano-base: 1996} & \multicolumn{6}{|c|}{ proporção por nivel de produtividade } \\
\hline & & 0,5150 & 0,1780 & 0,1810 & 0,1260 & dados totais \\
\hline & niveis de produt. & 0,750 & 1,500 & 4,000 & 7.000 & mitho \\
\hline & unioades & & & & & \\
\hline produça agricola & $1000 t$ & 5347631 & 3696615 & 10023780 & 12211290 & 31279316 \\
\hline àrea & ha & 7130175 & 2464410 & 2505945 & 1744470 & 13845000 \\
\hline produtividade & tha & 0,750 & 1,500 & 4,000 & 7,000 & 2,259 \\
\hline \% área empregando $N-F M N$ & 0,0 & 0,00 & 0,090 & 0,42 & 0,50 & 0.16 \\
\hline area utilizando $N-F M N$ & na & 0 & 221797 & 1052467 & 872235 & 2146529 \\
\hline producáo com N.FMN & t & 0,0 & 332695 & 4209988 & 6105645 & 10648328 \\
\hline ecessidadde de N-FMN/t output & $\mathrm{kg} \mathrm{N}$ ton out & 18,0 & 18,0 & 18,0 & 18,0 & 18,0 \\
\hline N-FMN apilcado/ha & $\mathrm{kg} \mathrm{N} / \mathrm{ha}$ & 0.0 & 27,0 & 72,0 & 126,0 & 88,5 \\
\hline N-FMN TOFAL & tons $\mathrm{N}$-fert & 0 & 5989 & 75780 & 109902 & 190000 \\
\hline proporcao N/FMN & Herot N & 3,5548 & 3,5548 & 3,5548 & 3.5548 & \\
\hline fertilizante & tFMN & 0 & 21288 & 269382 & 390678 & 681348 \\
\hline amònia & t amóniat FMN & 0,3875 & 0,3875 & 0,3875 & 0,3875 & \\
\hline amônia & t amona & -0 & 8249 & 104386 & 151388 & 264022 \\
\hline energia & GJjtamônia & 36,89 & 36,89 & 36,89 & 36,89 & \\
\hline energia & GJ total & 0 & 304309 & 3850781 & 5524697 & 9739787 \\
\hline produtividade & tha & 0,750 & 1,500 & 4,000 & 7,000 & 2,259 \\
\hline
\end{tabular}

\begin{tabular}{|c|c|c|c|c|c|c|c|}
\hline & & & \multicolumn{4}{|c|}{ niveis de prodtutividade } & dados totais \\
\hline ano 2000 & unidades & axas (\%a.a.) & 0,750 & $-1,500$ & 4,000 & 7,000 & milho \\
\hline produçäo agricola estimada & - & $3,80 \%$ & 5790217 & 3956730 & 12391322 & 15545497 & 37683767 \\
\hline area & há & 0,30 & $7 / 237771$ & 2501599 & 2543760 & 1770795 & 14053925 \\
\hline * area empregando $\mathrm{N}-\mathrm{FMN}$ & $\%(0)$ & estimado & 0.050 & 0,150 & 0,600 & 0,700 & 0,249 \\
\hline area utijzando N-FMN & ha & & 361889 & 375240 & 1526256 & 1239556 & 3502941 \\
\hline incremento na área com N-FMN & $\%(0.0)$ & & 0,050 & 0,060 & 0.180 & 0.200 & 0,094 \\
\hline produgao com N-FMN & $t$ & & 633305 & 767192 & 8321306 & 11826828 & 21548631 \\
\hline necessidade de $N-F M N / t$ output & $\mathrm{kgN/t}$ output & dado & 18,00 & 18,00 & 18,00 & 18,00 & 18,00 \\
\hline N-FMN aplicado/ha & $\mathrm{kgNina}$ & 6,39 & 18,00 & 36.80 & 98,14 & 171,74 & 109,33 \\
\hline N-FMN TOTAL & tons N-fert & $15,05 \%$ & 6514 & 13809 & 149784 & 212883 & 382990 \\
\hline Primeira medida - INCORPORAF & & & 1.0 & 10 & 1,0 & 1,0 & \\
\hline \% da area nova adotando & 0,0 & & 1,000 & 0,400 & 0,300 & 0,286 & \\
\hline IN-FMN equivalente & $t$ & & 6514 & 5524 & 44935 & 60824 & 117797 \\
\hline$\%$ total de $N$-fert. afetada & 0,0 & & 0,7 & 0,7 & 0,7 & 0.60 & 0.199 \\
\hline t de N-fert. & $\mathrm{t}$ & & 4560 & 3867 & 31455 & 36494 & 76375 \\
\hline potencial de economizar & 0,0 & & 0,15 & 0,15 & 0,15 & 0,20 & 0.035 \\
\hline total economizado & $t$ & & 684 & 580 & 4718 & 7299 & 13281 \\
\hline NOVO CONSUMO DE N-fert $>1$ & $\pi$ & & 5830 & 13229 & 145065 & 205504 & 369709 \\
\hline \% economizada c/ $1{ }^{1}$ medida & & & 0,000 & 0.042 & 0,032 & 0,034 & 0,035 \\
\hline unda medida - ADUBO VERDE & & & & & & & \\
\hline क da area nova adotando & 0,0 & & 0,000 & 0,000 & 0,000 & 0,000 & \\
\hline in-FMN equivalente & $\mathrm{t}$ & & 0 & 0 & 0 & 0 & 0 \\
\hline$\%$ total de $N$-fert atetada & 0,0 & & 0,700 & 0,700 & 0.100 & 0,360 & 0,000 \\
\hline TdeN-fert & $t$ & & 0 & 0 & 0 & 0 & 0 \\
\hline potencial de economizar & 0,0 & & 1,0 & 1,0 & 1,0 & 1,0 & 0,000 \\
\hline total economizado & t & & 0 & 0 & 0 & 0 & 0 \\
\hline NOVO CONSUMO OE N-fert2>7 & $\bar{t}$ & & 5830 & 13229 & 145065 & 205584 & 369709 \\
\hline$\%$ economizada $\mathrm{c} / 2^{2}$ medida & 0,0 & & 0,000 & 0,000 & 0,000 & 0,000 & 0,000 \\
\hline \% economizada total & 0.0 & & 0,1050 & 0,0420 & 0,0315 & 0,0343 & 0,0347 \\
\hline área utilizando adubo verde & hat & & 0 & 0 & 0 & 0 & 0 \\
\hline$-(-6$ & & & 0,000 & 0,000 & 0,000 & 0,000 & 0,000 \\
\hline IINCORPORAR & ha & 0.05 & 0 & 11090 & 52625 & 43612 & 107326 \\
\hline t $N-F M N$ equivalente & $t$ & & 0 & 408 & 5164 & 7490 & 130626 \\
\hline \% total de N-fert afetada & 0,0 & & 0,70 & 0,70 & 0,70 & 0,60 & 0,022 \\
\hline t de N-fmn & $\mathrm{t}$ & & 0 & 286 & 3615 & 4494 & 8395 \\
\hline potencial de economizar & 0,0 & & 0,15 & 0,15 & 0,15 & 0,2 & \\
\hline total economizado & $t$ & & 0 & 43 & 542 & 899 & 1484 \\
\hline NOVO CONSUMO DE N-fert3> & $t$ & & 5830 & 13187 & 144523 & 204685 & 368225 \\
\hline proporcăo NIFMN & tferth N & & 3.5548 & 3,5548 & 3,5548 & 3,5548 & \\
\hline fertilizante & $t F M N$ & & 20725 & 46876 & 513751 & 727615 & 1308966 \\
\hline amônia & tamóniat FMN & & 0,3875 & 0,3875 & 0,3875 & 0,3875 & \\
\hline amônia & tamónia & & 8031 & 18164 & 199078 & 281951 & 507224 \\
\hline energia & GJ/tamónia & & 36,89 & 36,89 & 36,89 & 36,89 & \\
\hline energia & G.J total & & 295255 & 670083 & 7344000 & 10401169 & 18711507 \\
\hline produtividade com FMN & tha & & 1,750 & 2,045 & 5,452 & 9,541 & 6,152 \\
\hline produtividade total por nivel & that & & 0.800 & 1,562 & 4,871 & 8,779 & 2,681 \\
\hline
\end{tabular}




\begin{tabular}{|c|c|c|c|c|c|c|c|}
\hline & & & \multicolumn{4}{|c|}{ niveis de produtividade } & \multirow{2}{*}{ dados totais } \\
\hline ano 2005 & unidades: & axas $\%$ ou. a. & 0,750 & 1,500 & 4.000 & 7,000 & \\
\hline producáo agricola estimada & tons & $5.56 \%$ & 7012364 & 4625905 & 16530771 & 21217700 & 49386740 \\
\hline area & ha & 0,30 & 7346991 & 2539348 & 2582146 & 1797516 & 14266002 \\
\hline \% area empregando N-FMN & 00 & estimado & 0,150 & 0,250 & 0700 & 0.800 & 0,349 \\
\hline área utilizando $\mathrm{N}$-FMN & ha & & 1102049 & 634837 & 1807502 & 1438013 & 4982401 \\
\hline incremento na área corn N-FMN & $\%(00)$ & & 0,100 & 0,100 & 0,100 & 0,100 & 0,300 \\
\hline produçó com N-FMN & $t$ & & 2328657 & 1769138 & 13432195 & 18701177 & 36231167 \\
\hline necessidade de N-FMNIt output & $\mathrm{kgN/t}$ output & dado & 18,00 & 18,00 & 18,00 & 18,00 & 18,00 \\
\hline N-FMN aplicadoha & $\mathrm{kgN} / \mathrm{ha}$ & 6,39 & 24,53 & 50,16 & 133,76 & 234,09 & 127,91 \\
\hline N-FMNTOTAL & tons $\mathrm{N}$-fert & $10,72 \%$ & 27038 & 31844 & 241780 & 336621 & 637283 \\
\hline primeira medida - INNCORFORA & & & 1,00 & 1,00 & 1,00 & 1,00 & \\
\hline$\%$ da area nova adotando [ & 0,0 & & 0,667 & 0,400 & 0.143 & 0,125 & \\
\hline t N-FMN equivalente & $\mathrm{t}$ & & 18025 & 12738 & 34540 & 42078 & 107381 \\
\hline$\%$ total de $\mathrm{N}$-fert. afetada & 0,0 & & 0.7 & 0,7 & 0,7 & 0.6 & 0.111 \\
\hline t de N-fert. & $t$ & & 12618 & 8916 & 24178 & 25247 & 70959 \\
\hline potencial de econorilzar & 0,0 & & 0,15 & 0,15 & 0,15 & 0.20 & 0.019 \\
\hline total econonizado & tf & & 1893 & 1337 & 3627 & 5049 & 11906 \\
\hline HOVO CONSUMOO OE N-terti> & t) & & 25146 & 30507 & 238153 & 331572 & 625377 \\
\hline$\%$ economizada ol $1^{\frac{1}{2}}$ medida & & & 0,1 & 0,0420 & 0,0150 & 0,0150 & 0,0187 \\
\hline unda medida - ADUBO VERDE & & & & & & & \\
\hline \% da area nova adotando & 0.0 & & 0,000 & 0,000 & 0,000 & 0,000 & \\
\hline t N-FMN equivalente & t & & 0 & 0 & 0 & 0 & 0 \\
\hline$\%$ total de N-fert afetada & 0,0 & & 0.7 & 0,7 & 0,7 & 0,3 & 0,000 \\
\hline tde N-fert & $\mathrm{t}$ & & 0 & 0 & 0 & 0 & 0 \\
\hline potencial de economizar & 0,0 & & 1,0 & 1,0 & 1,0 & 1,0 & \\
\hline total economizado & t & & 0 & 0 & 0 & 0 & 0 \\
\hline NOVO CONSUMO DE N-fert2> & $\mathrm{t}$ & & 25146 & 30507 & 238153 & 331572 & 625377 \\
\hline$\%$ econornizada $\mathrm{c} / 2^{\mathrm{a}}$ medida & 0,0 & & 0,0000 & 0,0000 & 0,0000 & 0,0000 & 0,000 \\
\hline$\%$ economirada total & 0,0 & & 0,0700 & 0,0420 & 0,0150 & 0,0150 & 0,019 \\
\hline area utilizando adubo verde & ha & & 0 & 0 & 0 & 0 & 0 \\
\hline$\%$ & & & 0.0000 & 0,0000 & 0,0000 & 0,0000 & 0,0000 \\
\hline INCORPORAR & ha & 0.10 & 0 & 22180 & 105250 & 87224 & 214653 \\
\hline IN-FMN equivalente & t & & 0 & 1113 & 14079 & 20418 & 35609 \\
\hline \% total de Nefert afetada & 0,0 & & 0,7000 & 0,7000 & 0,7000 & 0,3000 & 0,026 \\
\hline t deN-fmn & t & & 0 & 779 & 9855 & 6125 & 16759 \\
\hline potencial de economizar & 0,0 & & 0,15 & 0,15 & 0,15 & 0,2 & \\
\hline total economizado & $\mathrm{t}$ & & 0 & 117 & 1478 & 1225 & 2820 \\
\hline NOVO CONSUMO DE N-fert $3>$ & t & & 25146 & 30390 & 236675 & 330347 & 622557 \\
\hline proporfáo N/FMN & tfertit N & & 3,5548 & 3,5548 & 3,5548 & 3,5548 & \\
\hline fertilizante & tFMN & & 89387 & 108031 & 841331 & 1174317 & 2213066 \\
\hline amônia & tamôna $F M N$ & & 0.3875 & 0,3875 & 0,3875 & 0,3875 & \\
\hline amônia & tamónia & & 34638 & 41862 & 326016 & 455048 & 857563 \\
\hline energia & GJ/tamônia & & 36,89 & 36,89 & 36,89 & 36,89 & \\
\hline energia & GJ total & & 1277779 & 1544290 & 12026717 & 16786712 & 31635499 \\
\hline produtividade com FMN & t/ha & & 2,113 & 2,787 & 7,431 & 13,005 & 7,272 \\
\hline predutividade total por niveif & tha & & 0,954 & 1,822 & 6,402 & 11,804 & 3,462 \\
\hline
\end{tabular}

\begin{tabular}{|c|c|c|c|c|c|c|c|}
\hline & & & \multicolumn{4}{|c|}{ niveis de produtividade } & dados totais \\
\hline ano 2010 & unidades & axas (\%a.a.) & 0,750 & 1.500 & 4,000 & 7,000 & mifho \\
\hline produça agrícola estimada & tons & $5,03 \%$ & 9057270 & 5940102 & 24943067 & 23181392 & 63121831 \\
\hline area & hat & 0,30 & 7457859 & 2577668 & 2621112 & 1824641 & 14481280 \\
\hline$\%$ área empregando $\mathrm{N}-\mathrm{FMN}$ & 0.0 & estimado & $0250^{\circ}$ & 0.35 & 0,90 & 0,95 & 0,474 \\
\hline área utilizando $N-F M N$ & na & & 1864465 & 902184 & 2359001 & 1733409 & 6859053 \\
\hline ncremento na área com N-FMN & $\%(0.0)$ & & 0,100 & 0,100 & 0,200 & 0,150 & 0,124 \\
\hline producáo com N-FMN & & & 4862224 & 3426876 & 23894622 & 22542768 & 54726490 \\
\hline necessidade de N-FMN/t output & $\mathrm{kgN/t}$ output & dado & 18,00 & 18,00 & 18,00 & 18,00 & 18,00 \\
\hline N-FMN aplicado/ha & $\mathrm{kgNha}$ & 6,39 & 33,44 & 68,37 & 182,32 & 234.09 & 139,95 \\
\hline N-FMN TOTAL & tons $N$-fert & $8.54 \%$ & 62350 & 61684 & 430103 & 405770 & 959007 \\
\hline primeira medida - INCORPORAP & & & 1,0 & 1,0 & 10 & 10 & \\
\hline \% da área nova adotando & 0,0 & & 0,400 & 0,286 & 0,222 & 0,158 & \\
\hline t N-FMN equivalente & ti & & 24940 & 17624 & 95578 & 64069 & 202211 \\
\hline \% total de $\mathrm{N}$-fert. afetada & 0,0 & & 0,7 & 0,7 & 0.7 & 0,6 & 0,141 \\
\hline tode N-fert. & & & 17458 & 12337 & 66905 & 38441 & 135141 \\
\hline potencial de economizar & 0.0 & & 0,15 & 0,15 & 0,15 & 0.20 & 0.023 \\
\hline total economizado & ti & & 2619 & 1851 & 10036 & 7688 & 22193 \\
\hline NOVO CONSUMO DE $N$-fert? $>$ & tit & & 59731 & 59833 & 420067 & 398082 & 937713 \\
\hline \% economizada c/ 1 medida & & & 0,042 & 0,030 & 0,023 & 0,019 & 0,023 \\
\hline unda medida - ADUBO VERDE & & & & & & & \\
\hline \% da area nova adotando & 0,0 & & 0,000 & 0,000 & 0,000 & 0,000 & \\
\hline IN-FMN equivalente & $\mathrm{t}$ & & 0 & 0 & 0 & 0 & 0 \\
\hline \% total de N-fert. afetada & 0,01 & & 0,700 & 0,700 & 0,350 & 0,240 & 0,000 \\
\hline t de N-fert. & if & & 0 & 0 & 0 & 0 & 6 \\
\hline potencial de economizar & 0,0 & & 1,0 & 1,0 & 1,0 & 1,0 & \\
\hline total economizado & if & & 0 & 0 & 0 & 0 & 0 \\
\hline VOVO CONSUMOO DE N-fert2> & $t$ & & 59731 & 59833 & 420067 & 398082 & 937713 \\
\hline \% economizada c/ $2^{2}$ medida & 0,0 & & 0,000 & 0,000 & 0,000 & 0,000 & 0,000 \\
\hline$\%$ economizada total & 0,0 & & 0.042 & 0,030 & 0.023 & 0,019 & 0,023 \\
\hline area utilizando adubo verde & hat & & 0 & 0 & 0 & 0 & 0 \\
\hline$\%$ & & & 0,0000 & 0,0000 & 0,0000 & 0,0000 & 0,0000 \\
\hline INCORPORAR & hat & 0,15 & 0 & 33270 & 157875 & 130835 & 321979 \\
\hline T N-FMN equivalente & $\mathrm{t}$ & & 0 & 2275 & 28784 & 30627 & 61686 \\
\hline \% total de N-fert afetada & 0,0 & & 0,7000 & 0,7000 & 0,3500 & 0,2400 & 0,020 \\
\hline t de N-fmn & t & & 0 & 1592 & 10075 & 7350 & 19017 \\
\hline potencial de economizar & 0,0 & & 0,15 & 0,15 & 0,15 & 0,2 & \\
\hline total economizado & if & & 0 & 239 & 1511 & 1470 & 3220 \\
\hline NOVO CONSUMO DE N-fert $3>$ & $-m$ & & 59731 & 59594 & 418556 & 396611 & 934493 \\
\hline proporça N/FMN & tfert N & & 3.5548 & 3.5548 & 3,5548 & 3.5548 & \\
\hline fertilizante & FMN & & 212332 & 211846 & 1487884 & 1409874 & 3321936 \\
\hline amônia & $t$ amoniait FMN & & 0.3875 & 0,3875 & 0,3875 & 0.3875 & \\
\hline amónia & tamónia & & 82279 & 82090 & 576555 & 546326 & 1287250 \\
\hline energia & GJ/tamónia & & 36,89 & 36,89 & 36,89 & 36,89 & \\
\hline energia & G.J total & & 3035260 & 3028315 & 21269114 & 20153978 & 47486667 \\
\hline produtividade com FMN & tha & & 2,608 & 3,798 & 10,129 & 13,005 & 7.979 \\
\hline produtividade total por niveit & & & 1,214 & 2,304 & 9,516 & 12,705 & 4,359 \\
\hline
\end{tabular}


CENÁRIO ADUBO VERDE II

\begin{tabular}{|c|c|c|c|c|c|c|}
\hline \multirow{3}{*}{ ano-base: 1996} & \multicolumn{6}{|c|}{ proporçāo por nivel de produtividade } \\
\hline & & 0.5150 & 0.1780 & 0,1810 & 0.1260 & Tdados totais \\
\hline & niveis de produt. & 0,750 & 1,500 & 4,000 & 7.000 & milho \\
\hline & Unidades & & & & & \\
\hline produça agricola & $1000 t$ & 5347631 & 3696615 & 10023780 & 12211290 & 31279316 \\
\hline area & ha & 7130175 & 2464410 & 2505945 & 1744470 & 13845000 \\
\hline produtividade & tha & 0,750 & 1,500 & 4,000 & 7,000 & 2.259 \\
\hline \% area empregando $N-F M N$ & 0.0 & 0,00 & 0,090 & 0,42 & 0.50 & 0,16 \\
\hline area utitizando $N-F M N$ & na & 0 & 221797 & 1052497 & 872235 & 2146529 \\
\hline producâo com N-FMN & $\bar{t}$ & 0,0 & 332695 & 4209988 & 6105645 & 10648328 \\
\hline necessidade de N-FMN/t output & $\mathrm{kg} \mathrm{N}$ fton out & 18,0 & 18,0 & 18,0 & 18,0 & 18,0 \\
\hline N-FMN aplicadoha & $\mathrm{kg} \mathrm{N} / \mathrm{ha}$ & 0,0 & 27,0 & 72,0 & 126,0 & 89,3 \\
\hline N.FMN TOTAL & tons N-fert & 0 & 5989 & $75780^{\circ}$ & 109902 & 191670 \\
\hline proporcao N/FMN & tferti $\mathrm{N}$ & 3,5548 & 3,5548 & 3,5548 & 3,5548 & \\
\hline fertilizante & $\mathrm{t} F M N$ & 0 & 21288 & 269382 & 390678 & 681348 \\
\hline amónia & t amóniat FMN & 0,3875 & 0,3875 & 0.3875 & 0,3875 & \\
\hline amónia & tamôna & 0 & 8249 & 104386 & 151388 & 264022 \\
\hline energia & GJjtamônia & 36,89 & 36,89 & 36,89 & 36,89 & \\
\hline energia & GJ tưtal & 0 & $304309^{\circ}$ & 3850781 & 5584697 & 9739787 \\
\hline produtividade & tha & $0,750^{\circ}$ & 1,500 & 4,000 & 7,000 & 2.259 \\
\hline
\end{tabular}

\begin{tabular}{|c|c|c|c|c|c|c|c|}
\hline & & & \multicolumn{4}{|c|}{ niveis de produtividade } & dados totais \\
\hline ano 2000 & unidades & axas (\%a.a.) & 0,750 & 1,500 & 4,000 & 7,000 & mitho \\
\hline producăo agricola estimada & - & $3.80 \%$ & 5790217 & 3956730 & 12391322 & 15545497 & 37683767 \\
\hline area & ha & 0,30 & 7237771 & 2501599 & 2543760 & 1770795 & 14053925 \\
\hline \% area empregando $\mathrm{N}-\mathrm{FMN}$ & $\%(0.0)$ & estimado & 0,050 & 0,150 & 0,600 & 0.700 & 0.249 \\
\hline area utilizando N-FMN & ha & & 361889 & 375240 & 1526256 & 1239556 & 3502941 \\
\hline incremento na area con N-FMN & $\%(0.0)$ & & 0,050 & 0,060 & 0,180 & 0,200 & 0,094 \\
\hline producáo com N-FMN & $\mathrm{t}$ & & 633305 & 767192 & 8321306 & 11826828 & 21548631 \\
\hline necessidade de N-FMNit output & $\mathrm{kgN} / t$ output & dado & 18,00 & 18,00 & 18.00 & 18,00 & 18,00 \\
\hline N-FMN aolicado'ha & $\mathrm{kgN} / \mathrm{ha}$ & 6.39 & 18,00 & $36.80^{\circ}$ & 98.14 & 17174 & 10933 \\
\hline N-FMN TOTAL & tons N-fert & $14,85 \%$ & 6514 & 13809 & 149784 & 212883 & 382990 \\
\hline primeira medida - INCORPORAR & & & 0,0 & 0.0 & 0,0 & 0,0 & \\
\hline$\%$ da área nova adotando & 0.0 & & 0,000 & 0,000 & 0,000 & 0,000 & \\
\hline t N-FMN equivalente & $\mathrm{t}$ & & 0 & 0 & of & 0 & 0 \\
\hline$\%$ total de N-fert afetada & 0,0 & & 0,7 & 0,7 & 0,7 & 0,60 & 0,000 \\
\hline te N-fert. & $t$ & & 0 & 0 & of & o & 0 \\
\hline potencial de economizar & 0.0 & & 0,15 & 0,15 & 0,15 & 0,20 & 0,000 \\
\hline total economizado & $t$ & & 0 & 0 & of & 0 & 0 \\
\hline NOVO CONSUMO DE N-fert Is & t) & & 6514 & 13809 & 449784 & 212883 & 382990 \\
\hline \% economizada o/ 19 medida & & & 0,000 & 0,000 & 0,000 & 0,000 & 0,000 \\
\hline secunda medida - ADÜBO VERDE & & & & & & & \\
\hline \& da area nova adotando & 0,0 & & 1,000 & 0,400 & 0,300 & 0,286 & \\
\hline t N-FMN equivalente & $\mathrm{t}$ & & 6514 & 5524 & 44935 & 60824 & 117797 \\
\hline \% total de N-fert atetada & 0,0 & & 1,000 & 1,000 & 0,815 & 0,466 & 0,201 \\
\hline tde N-fert. & $\mathrm{t}$ & & 6514 & 5524 & 36630 & 28333 & 77001 \\
\hline potencial de economizar & 0,0 & & 1,0 & 10 & 1.0 & 10 & 0,201 \\
\hline total economizado & $\mathrm{t}$ & & 6514 & 5524 & 36530 & 28333 & 77001 \\
\hline NOVO CONSUMO DE N-fert2> & $t$ & & 0 & 8286 & 113153 & 184550 & 305989 \\
\hline$\%$ economizada $\mathrm{c} / 2^{\mathrm{a}}$ medida & 0,0 & & 0,472 & 0.400 & 0,245 & 0,133 & 0,201 \\
\hline$\%$ exonomizada total & 0.0 & & 1.0000 & 0,4000 & 0,2446 & 0,1331 & 0,2011 \\
\hline área utilizando adubo verde & ha & & 361889 & 150096 & 457877 & 354159 & $1324020^{\circ}$ \\
\hline$\%$ & & & 0.050 & 0.060 & 0.180 & 0.200 & 0.094 \\
\hline com FMN mas mudando para A.V. & ha & 0,05 & 0 & 11090 & 52625 & 43612 & 107326 \\
\hline t $N-F M N$ equivalente & $t$ & & 0 & 408 & 5164 & 7490 & 13062,6 \\
\hline \% total de N-fert atetada & 0,0 & & 1,00 & 1,00 & 0.815 & 0,466 & 0,021 \\
\hline toe N-fmn & $\mathrm{t}$ & & 0 & 408 & 4210 & 3489 & 8107 \\
\hline potencial de economizar & 0.0 & & 1,0 & 1,0 & 1,0 & 1,0 & \\
\hline total economizado & $\mathrm{t}$ & & 0 & 408 & 4210 & 3489 & 8107 \\
\hline NOVO CONSUMO DE N-fert3> & $t$ & & - o & 7878 & 108943 & 181061 & 297882 \\
\hline proporça N/FMN & tfettin & & 3,5548 & 3,5548 & 3,5548 & 3,5548 & \\
\hline fertilizante & tFMN & & 0 & 28003 & 387272 & 643637 & 1058912 \\
\hline amónia & tamooniat FMN & & 0,3875 & 0.3875 & 0,3875 & 0.3875 & \\
\hline amônia & tamónia & & 0 & 10851 & 150068 & 249409 & 410328 \\
\hline energla & GJjtamônia & & 36,89 & 36,89 & 3689 & 36,89 & \\
\hline energia & G. total & & 0 & 400301 & 5536003 & 9200704 & 15137008 \\
\hline produtividade com FMN & tha & & 1,750 & 2,045 & 5,452 & 9,541 & 6,152 \\
\hline produtivioade total of nivel & tha & & $0.800^{\circ}$ & 1,582 & 4871 & 6,779 & $2,6 \mathrm{~B} 1$ \\
\hline
\end{tabular}


niveis de produtividade

\begin{tabular}{|c|c|c|c|c|c|c|c|}
\hline & & & \multicolumn{4}{|c|}{ niveis de produtividade } & Jados totais \\
\hline ano 2005 & unídades & axas $(\% a \cdot a)$ & 0.750 & 1.500 & 4,000 & 7,000 & milke \\
\hline producăo agrícola estimada & tons & $5.56 \%$ & 7012364 & 4625905 & 16530771 & 21217700 & 49386740 \\
\hline area & ha & 0.30 & 7346991 & 2539348 & 2582146 & 1797516 & 14266002 \\
\hline * area empregando $N-F M N$ & 0.0 & estimado & 0,150 & 0,250 & 0,700 & 0,800 & 0,349 \\
\hline area utilizando N-FMN & ha & & 1102049 & 634837 & 1807502 & 1438013 & 4982401 \\
\hline incremento na área com N-FMN & $\%(0.0)$ & & 0,100 & 0,100 & 0,100 & 0,100 & 0,100 \\
\hline producáo com N-FMN & $-\quad-\quad t$ & & 2328657 & 1769138 & 13432195 & 18701177 & 36231167 \\
\hline necessidadde de N-FMN/t output & $\mathrm{kgN/t}$ output & dado & 18,00 & 18,00 & 18,00 & 18,00 & 18,00 \\
\hline N-FMN aplicado/ha & $\mathrm{kgN} / \mathrm{ha}$ & 6.39 & 24,53 & 50,16 & 13376 & 234,09 & 127.91 \\
\hline NFMN TOTAL & tons N-fert & $10,72 \%$ & 27038 & 31844 & 241780 & 336621 & 637283 \\
\hline primeira medida - INOORPORAR & & & 0,00 & 0,00 & 0.00 & 0,00 & \\
\hline \% da area nova adotando & 0,0 & & 0,000 & 0,000 & 0,000 & 0,000 & \\
\hline t $N-F M N$ equivalente & 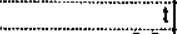 & & 0 & 0 & 0 & 0 & \\
\hline \% total de N-fert afetada & 0,0 & & 0,7 & 07 & 0,7 & 0,6 & 0.0 \\
\hline-1 de N-fert. & $t$ & & 0 & 0 & 0 & 0 & \\
\hline potencial de economizar & 0,0 & & 0,15 & 0,15 & 0,15 & 0,20 & 0,00 \\
\hline total economizado & t & & 0 & 0 & 0 & 0 & \\
\hline NOVO CONSUMO DE N-fert1 > & $t$ & & 27038 & 31844 & 241780 & 336621 & 637283 \\
\hline \% economizada $\mathrm{c} / \mathrm{f}$ medida & & & 0,0 & 0.0000 & 0,0000 & 0,0000 & 0,0000 \\
\hline secunda medida - ADUBO VEROEZ & & & & & & & \\
\hline \% da area nova adotando & 0,0 & & 0,667 & 0.400 & 0,143 & 0,125 & \\
\hline tN-FMN equivalente & $t$ & & 18025 & 12738 & 34540 & 42078 & 10738 \\
\hline$\%$ total de N-fert afetada & 0,0 & & 1,000 & 1,000 & 0,598 & 0,342 & 0,103 \\
\hline t teN-fett & -1 & & 18025 & 12738 & 20657 & 14380 & 65801 \\
\hline potencial de economizar & 0.0 & & 1,0 & 10 & 10 & 1,0 & \\
\hline total economizado & -1 & & 18025 & 12738 & 20657 & 14380 & 65801 \\
\hline NOVO CONSUMO DE N-fert2s & -1 & & 9013 & 19107 & 221122 & 322241 & 571483 \\
\hline \% economizada $c / 2^{2}$ medida & 0,0 & & 0,6667 & 0,4000 & 0,0854 & 0,0427 & 0,103 \\
\hline \% economizada total & 0,0 & & 0.6667 & 0,4000 & 0,0854 & 0,0427 & 0,103 \\
\hline área utitizando adubo verde & ha & & 734699 & 253935 & 258215 & 179752 & 1426600 \\
\hline$-1-1$ & & & 0,1000 & 0,1000 & 0,1000 & 0.1000 & 0,1000 \\
\hline com FMN mas mudando para AV & ha & 010 & $-1-0$ & 22180 & 105250 & 87224 & 21465 \\
\hline tN-FMN equivalente & $t$ & & 0 & 1113 & 14079 & 20418 & 3560 \\
\hline \% total de N-fert afetada & 0,0 & & 1,0000 & 1,0000 & 0,5981 & 0,3418 & 0,02 \\
\hline t deN-fmn & $t$ & & -0 & $\begin{array}{r}1113 \\
\end{array}$ & 8420 & 6978 & 1651 \\
\hline potencial de economizar & 0.0 & & 1,0 & 1,0 & 10 & 1,0 & \\
\hline total economizado & $t$ & & 0 & 1113 & 8420 & 6978 & 1651 \\
\hline NOVO CONSUMO DE N-fert 3 & & & 9013 & 17994 & 212702 & 315263 & 55497 \\
\hline proporcáo N/FMN & tertin & & 3,5548 & 3,5548 & 3,5548 & 3,5548 & \\
\hline fertilizante & TFMN & & 32038 & 63965 & 7566114 & 1120698 & 1972816 \\
\hline amónia & t amóniát FMN & & 0,3875 & 0,3875 & 0,3875 & 0,3875 & \\
\hline amônia & tamônia & & 12415 & 24787 & 292994 & 434270 & 764466 \\
\hline energia & GJ/tamônia & & 36,89 & 36,89 & 36,89 & 36,89 & \\
\hline energia & GJ total & & 457985 & 914379 & 10808560 & 16020232 & 2820115 \\
\hline produtividade com FMN & t/he & & 2,113 & $\begin{array}{r}2,787 \\
\end{array}$ & 7,431 & 13,005 & 7,27 \\
\hline produtividade total por nivel & tha & & 0,954 & 1,622 & 6,402 & 11,804 & 3,46 \\
\hline
\end{tabular}

\begin{tabular}{|c|c|c|c|c|c|c|c|}
\hline & & & \multicolumn{4}{|c|}{ niveis de produtividade } & dados totais \\
\hline ano 2010 & unidades & axas (\%a.a.) & 0,750 & 1,500 & 4,000 & 7,000 & milho \\
\hline produção agrícola estimada & tons & $5,03 \%$ & 9057270 & 5940102 & 24943067 & 23181392 & 63121831 \\
\hline area & ha & 0,30 & 7457859 & 2577668 & 2621112 & 1824641 & 14481280 \\
\hline \% area empregando N-FMN & 0,0 & estimado & 0,250 & 0,35 & 090 & 0,95 & 0,474 \\
\hline area utilizando N-FMN & ha & & 1864465 & 902184 & 2359001 & 1733409 & 6850058 \\
\hline incremento na área com N-FMN & $\%(0.0)$ & & 0.100 & 0,100 & 0,200 & 0,150 & 0.124 \\
\hline producáo com N-FMN & -1 & & 4862224 & 3426876 & 23894622 & 22542768 & 54726490 \\
\hline necessidade de N-FMNIt outpurt & $\mathrm{kgNA}$ output & dado & 18,00 & 18,00 & 18,00 & 18,00 & 18,00 \\
\hline N-FMN aplicado/ha & $\mathrm{kgN} / \mathrm{ha}$ & 6.39 & 33,44 & 68,37 & 182,32 & 234.09 & 139.95 \\
\hline N-FMN TOTAL & tons N-fert & $8.54 \%$ & 62350 & 61684 & 430303 & 405770 & 959907 \\
\hline ghmeira medida - INCORPORAR & & & 0,0 & 0,0 & 0.0 & 0,0 & \\
\hline$\%$ da area nova adotando & 0,0 & & 0,000 & 0,000 & 0,000 & 0,000 & \\
\hline t N-FMN equivalente & & & - & 0 & of & of & 0 \\
\hline \% total de N-fert afetada & 0,0 & & 0,7 & 0,7 & 0,7 & 0,6 & 0,000 \\
\hline t de N-fert. & $t$ & & 0 & 0 & 0 & of & 0 \\
\hline potencial de economizar & 0,0 & & 0,15 & 0.15 & 0,15 & 0.20 & 0,000 \\
\hline total economizado & -1 & & 0 & 0 & of & of & o \\
\hline NOVO CONSUMO DE N-ferti> & $t$ & & 62350 & 61684 & 430103 & 405770 & 959907 \\
\hline$\%$ economizada o $1 \%$ medida & & & 0,000 & 0,000 & 0,000 & 0,000 & 0,000 \\
\hline secunda medida - ADUBO VERDE & & & & & & & \\
\hline \% da área nova adotando & 0,0 & & 0.400 & 0,266 & 0,222 & 0,158 & \\
\hline tN-FMN equivalente & $t$ & & 24940 & 17624 & 95578 & 64069 & 202211 \\
\hline \% total de N-fert. afetada & 0,0 & & 1,000 & 1,000 & 0,439 & 0,342 & 0,111 \\
\hline t de N-fert & $i$ & & 24940 & 17624 & 41938 & 21896 & 106397 \\
\hline potencial de economizar & 0,0 & & 1,0 & 1,0 & 1,0 & 1,0 & \\
\hline total economizado & $\mathrm{t}$ & & 24940 & 17624 & 41938 & 21896 & 106397 \\
\hline NOVO CONSUMO DE N-fert2> & it & & 37410 & 44060 & 388165 & 383874 & 853509 \\
\hline \% economizada ol $2^{2}$ medida & 0,0 & & 0,400 & 0,286 & 0,098 & 0,054 & 0,111 \\
\hline$\%$ economizada totai & 0,0 & & 0,400 & 0,286 & 0,098 & 0,054 & 0,111 \\
\hline area utilizzando adubo verde & hat & & 745786 & 257767 & 524222 & 273696 & 1801471 \\
\hline & & & 0,1000 & 0,1000 & 0.2000 & 0,1500 & 0,1244 \\
\hline com FMN mas mudando para A.V. & ha & 0,15 & of & 33270 & 157875 & 130835 & 321979 \\
\hline t $N$-FMN equivalente & & & of & 2275 & 28784 & 30627 & 61686 \\
\hline \% total oe N-fert afetada & 0,0 & & 1,0000 & 1,0000 & 0.4388 & 0,3418 & 0,026 \\
\hline tdeN-fmn & & & -0 & 2275 & 12630 & 10467 & 25374 \\
\hline potencial de economizar & 0,0 & & 1,0 & 1,0 & 1,0 & 1,0 & \\
\hline total economizado & & & of & 2275 & 12630 & 10467 & 25371 \\
\hline NOVO CONSUMO DE N-fert3 & & & 37410 & 41785 & 375535 & 373407 & 828138 \\
\hline proporçäo NIFMN & tfertt N & & 3,5548 & 3,5548 & 3,5548 & 3,5548 & \\
\hline fertilizante & TFMN & & 132985 & 148538 & 1334953 & 1327388 & 2943864 \\
\hline amonia & t amóniaf FMN & & 0,3875 & 0,3875 & 0,3875 & 0,3875 & \\
\hline amônia & tamónia & & 51532 & 57558 & 517294 & 514363 & 1140747 \\
\hline energia & GJjamónia & & 36,89 & 36,89 & 36,89 & 36,89 & \\
\hline energia & GJ total & & 1900998 & 2123330 & 19082992 & 18974850 & 42082169 \\
\hline produtividade com FMN & tha & & 2,608 & 3,798 & 10,129 & 13,005 & 7,979 \\
\hline produtividade tolal por nivell & & & 1,214 & 2,304 & 9,516 & 12,705 & 4,359 \\
\hline
\end{tabular}




\section{CENÁRIO SIMULTÂNEO II}

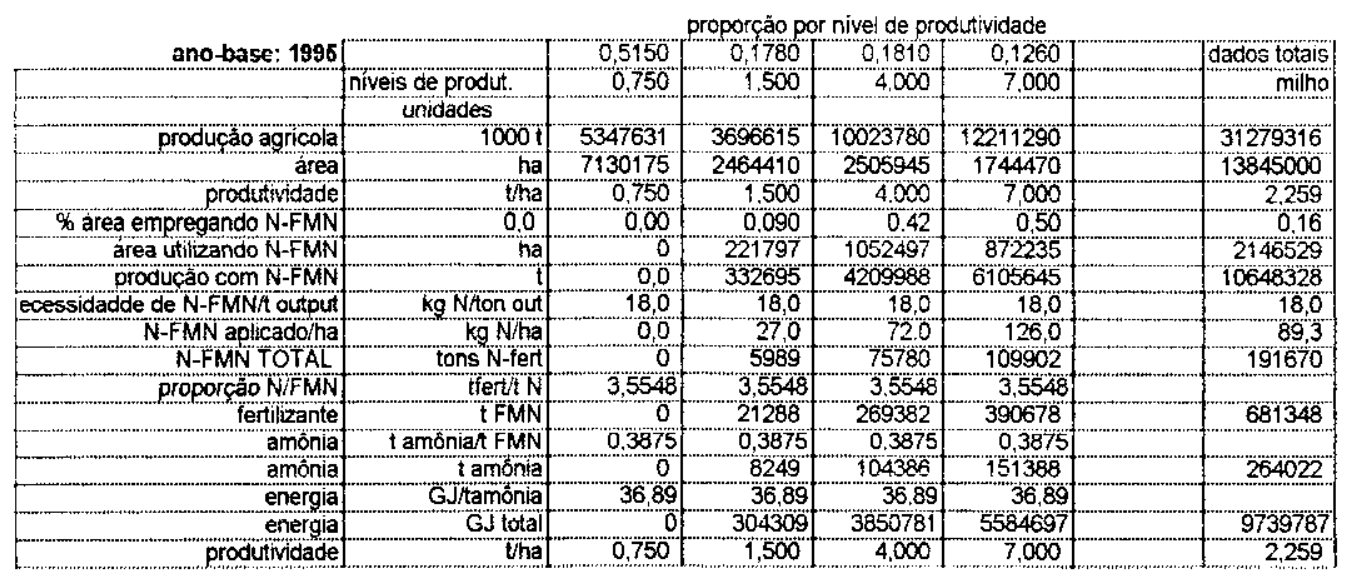

\begin{tabular}{|c|c|c|c|c|c|c|c|}
\hline & & & \multicolumn{4}{|c|}{ niveis de produtividade } & [dados totais] \\
\hline ano 2000 & unidades & axas (\%a.a.) & 0.750 & $1.500^{\circ}$ & 4.000 & 7,000 & milho \\
\hline producâo agricola estimada & $\mathrm{t}$ & $3,80 \%$ & 5790217 & 3956730 & 12391322 & 15545497 & 37683767 \\
\hline areat & hat & 0,30 & 72377841 & $250+590$ & $2543760^{\prime}$ & 1770795 & 14053925 \\
\hline$\%$ area empregando $N-F M N$ & $\%(00)$ & estimado & 0,050 & 0,150 & 0,600 & 0,700 & 0.249 \\
\hline área utilizando N-FMN & ha & & 361089 & 375240 & 1526256 & 1239556 & 3502941 \\
\hline Bcremento na ajea com N-FMN & $\%(0.0)$ & & 0.050 & 0,060 & 0,180 & 0,200 & 0,094 \\
\hline producao com N-FMN & $t$ & & 6333305 & 767192 & 8321306 & 11826828 & 21548631 \\
\hline necessidade de N-FMMN/t output & $\mathrm{kgNAt}$ outpuit & dado & 18,00 & 18,00 & 18,00 & 18,00 & 18,00 \\
\hline N-FMN aplicadóha & $\mathrm{kgNh} / \mathrm{ha}$ & 6,39 & 18,00 & 36,80 & 98,14 & 171,74 & 109,33 \\
\hline N-FMN TOTAL & tons N-fert & $14,85 \%$ & 6514 & 13809 & 149784 & 212883 & 382990 \\
\hline primeira medida - INCORPORAF & & & 0,5 & 0,5 & 0,5 & 0.5 & \\
\hline \% da area nova adotando & 0,0 & & 0.500 & 0.200 & 0,150 & 0,143 & \\
\hline IN-FMN equivalente & if & & 3257 & 2762 & 22468 & 30412 & 50898 \\
\hline$\%$ total de N-fert. afetada & 0.01 & & 0,7 & 0,7 & 0,7 & 0,60 & 0,100 \\
\hline t de N-fert & $\mathrm{t}$ & & 2280 & 1933 & 15727 & 18247 & 38188 \\
\hline potencial de economizar & 0,0 & & 0,15 & 0.15 & 0,15 & 0.20 & 0.017 \\
\hline total economizado & $t$ & & 342 & 290 & 2359 & 3649 & 6640 \\
\hline NOVO CONSUMO DE N-fert $>$ & $t$ & & 6172 & 33519 & 147424 & 209233 & 376349 \\
\hline \% economizada $\mathrm{cl} / \mathrm{l}$ medida & & & 0.025 & 0.021 & 0,016 & 0,017 & 0.017 \\
\hline Unda medida - ADUBO VERDE & & & & & & & \\
\hline \% da area nova aóotando & 0.0 & & 0.500 & 0,200 & 0,150 & 0,943 & \\
\hline t N-FMN equivalente & $\mathrm{t}$ & & 3257 & 2762 & 22468 & 30412 & 58898 \\
\hline \% total de N-fert afetada & 0,0 & & $1,0 \infty$ & 1.000 & 0,815 & 0.466 & 0.107 \\
\hline t de N-fert & if & & 3257 & 2762 & 18315 & 14166 & 38500 \\
\hline potencial de economizar & 0,0 & & 1,0 & 1,0 & 1,0 & 1,0 & 0.101 \\
\hline total economizado & fi & & 3257 & $27 \bar{E} 2$ & $163 ! 5$ & 14166 & 38500 \\
\hline NOVO CONSÜMO DE N-fert2> & $\mathrm{t}$ & & 2915 & 10758 & 129109 & 195067 & 337849 \\
\hline$\%$ economizada $\mathrm{c} / 2^{\mathrm{a}}$ medida & 0,0 & & 0,236 & 0,200 & 0,122 & 0,067 & 0,101 \\
\hline \% economizada totai & 0,0 & & 0.5525 & 0.2210 & 0,1380 & 0.0837 & 0,1179 \\
\hline area utilizando adubo verde & hat & & 180944 & 75048 & 228938 & 177079 & 662010 \\
\hline$\%$ & & & 0,025 & 0.030 & 0,090 & 0.100 & 0,047 \\
\hline INCORPORAR & 0,05 ha & 0,03 & 0 & 5545 & 26312 & 21806 & 53663 \\
\hline IN-FMN equivalente & $-t$ & & 0 & 204 & 2582 & 3745 & 6531,3 \\
\hline \% total de N.fert. afetada & 0,0 & & 0,70 & 0,70 & 0,70 & 0,60 & 0,011 \\
\hline t de N-fmn & $\mathrm{t}$ & & 0 & 143 & 1808 & 2247 & 4197 \\
\hline potencial de economizar & 0,0 & & 0,85 & 0,15 & 0.15 & 0,2 & \\
\hline total economizado & $\mathrm{t}$ & & 0 & 21 & 271 & 449 & 742 \\
\hline NOVO CONSUMMO DE N-fert $3>$ & $t$ & & 2915 & 10736 & 128838 & 194618 & 337107 \\
\hline ADUBOO VERDE & ha & 0,03 & 0 & 5545 & 26312 & 21806 & 53663 \\
\hline tN-FMN equivalente & if & & 0 & 204 & 2582 & 3745 & 6531 \\
\hline$\%$ total de $\mathrm{N}$-fert, afelada & 0,0 & & 9,000 & 1.000 & 0.815 & 0,466 & \\
\hline t deN-fmn & $t$ & & 0 & 204 & 2105 & 1744 & 4054 \\
\hline potencial de economizar & 0,0 & & 1,0 & 1,0 & 1,0 & 1,0 & \\
\hline total economizado & t & & 0 & 204 & 2105 & 1744 & 4054 \\
\hline NOVO CONSUMO DE N-fert4s & $\mathrm{t}$ & & 2915 & 10532 & 126733 & 192873 & 333054 \\
\hline proporcáo N/FMN & tfert N & & 3,5548 & 3,5548 & 3,5548 & 3,5548 & \\
\hline fertilizante & $t F M N$ & & 10362 & 37439 & 450511 & 685626 & 1183939 \\
\hline amónia & tamoniat FMN & & 0,3875 & 0,3875 & 0,3875 & 0,3875 & \\
\hline amónia & tamoิnia & & 4015 & 14508 & 174573 & 265680 & 458776 \\
\hline energia & GJ/tamônia & & 36,89 & 36.89 & 36,89 & 36,89 & \\
\hline energia & Gjtotal & & 148128 & 535192 & 6440002 & 900036 & 16924258 \\
\hline produtividade com FMN & tha & & 1.750 & 2,045 & 5,452 & 9,541 & 6,152 \\
\hline produtividade total por nivel & tha & & 0,800 & 1,582 & 4,871 & 8,779 & 2,681 \\
\hline
\end{tabular}




\begin{tabular}{|c|c|c|c|c|c|c|c|}
\hline & & & \multicolumn{4}{|c|}{ niveis de produtividade } & dados totais \\
\hline ano 2005 & Uñuades & axas (\%a.a.) & 0,750 & $1.500 \mathrm{~J}$ & 4,000 & 7.000 & milió \\
\hline produçáo agricola estimada & tons & $5,56 \%$ & 7012364 & 4625905 & 16530771 & 21217700 & 49386740 \\
\hline area & ha & 0.30 & 7346991 & 2539348 & 2582146 & 1797516 & 14266002 \\
\hline \% area empregando $N-F M N$ & 0,0 & estimado & 0,150 & $0,250^{\circ}$ & 0,700 & 0,800 & 0.349 \\
\hline area utilizando N-FMN & ha & & 1102049 & 634837 & 1807502 & 1438013 & 4982401 \\
\hline incremento ha area com N-FMN & $\%(0.0)$ & & 0,100 & 0,100 & 0,100 & 0,100 & 0,100 \\
\hline produgäo com N-FMN & t & & 2328657 & 1769138 & 13432195 & 18701177 & 36231167 \\
\hline necessidade de N-FMN/T output & $\mathrm{kgNAt}$ output & dado & 18,00 & 18,00 & 18,00 & 18,00 & 18,00 \\
\hline N-FMN aplicadoiha & $\mathrm{kgNha}$ & 6.39 & 24,53 & 50,16 & 133,76 & 23409 & 127,91 \\
\hline N-FMN TOTAL & tons N-fert & $10,72 \%$ & 27038 & 31844 & 241780 & 336621 & 637283 \\
\hline primeira medida - INCORPORAF & & & 0,50 & 0.50 & 0.50 & 0.50 & \\
\hline \% da área nova adotando & 0,0 & & 0,333 & 0,200 & 0,071 & 0,063 & \\
\hline I N-FMN equivatente & i & & 9013 & 6369 & 17270 & 21039 & 53690 \\
\hline$\%$ total de N-fert afetada & 0,0 & & 0,7 & 0,7 & 07 & 0.6 & 0,056 \\
\hline t de N-fert & it & & 5309 & 4458 & 12089 & 12623 & 35479 \\
\hline potencial de economizar & 0.0 & & 0,15 & 0,15 & 0.15 & 0,20 & 0,008 \\
\hline total economizado & $\mathrm{t}$ & & 946 & 669 & 1813 & 2525 & 5953 \\
\hline NOVO CONSUMO OE N-tert $1>$ & $t$ & & 26092 & 39176 & 239966 & 334097 & 631330 \\
\hline \% economizada $\mathrm{c} / 1^{2}$ medida & & & 0,0 & 0,0210 & 0,0075 & 0,0075 & 0.0093 \\
\hline Unda medida-ADUBO VERDE & & & & & & & \\
\hline \% da alea nova adotando & 0.0 & & 0,333 & 0,200 & 0.071 & 0.063 & \\
\hline in-FMN equivalente & & & 9013 & 6369 & 17270 & 21039 & 53690 \\
\hline$\%$ total de N-fert afetada & 0,0 & & 1,000 & 1,000 & 0,598 & 0,342 & 0,052 \\
\hline de $\mathrm{N}$-fert. & t & & 9013 & 6369 & 10329 & 7190 & 32900 \\
\hline potencial de economizar & 0,0 & & 1,0 & 1,0 & 1,0 & 1,0 & \\
\hline total economizado & $t$ & & 9013 & 6369 & 10329 & 7190 & 32900 \\
\hline NOVO CONSUMO DE N-fert2> & $t$ & & 17079 & 24807 & 229638 & 326906 & $598430^{\circ}$ \\
\hline$\%$ economizada $\mathrm{c} / 2^{2}$ medida & 0,0 & & 0,3333 & 0,2000 & 0,0427 & 0,0214 & 0,052 \\
\hline$\%$ economizada total & 0,0 & & 0,3683 & 0,2210 & 0,0502 & 0.0289 & 0,061 \\
\hline area utilizando adubo verde & na & & 367350 & 126967 & 129107 & 89876 & 713300 \\
\hline$\%$ & & & 0.0500 & 0,0500 & 0,0500 & 0,0500 & 0,0500 \\
\hline INCORPORAR & 0,10 ha & 0,05 & 0 & 11090 & 52625 & 43612 & 107326 \\
\hline tN-FMN equivalente & $t$ & & of & 556 & 7039 & 10209 & 17805 \\
\hline \% total de N-fert afetada & 0,0 & & 0,7000 & 0,7000 & 0,7000 & 0,3000 & 0,013 \\
\hline tdeN-fmn & $t$ & & 0 & 389 & 4928 & 3063 & 8380 \\
\hline potencial de economizar & 0,0 & & 0.15 & 0,15 & 0,15 & 0,2 & \\
\hline total economizado & t & & 0 & 58 & 739 & 613 & 1410 \\
\hline NOVO CONSUMO DE N-fert3> & it & & 17079 & 24748 & 228898 & 326294 & 597020 \\
\hline ADUBO VERDE & ha & 0,05 & 0 & 11090 & 52625 & 43612 & \\
\hline TN-FMN equivalente & $t$ & & 0 & 556 & 7039 & 10209 & 17805 \\
\hline \$ total de N-fert afetada & 0,0 & & 1,000 & 1,000 & 0.598 & 0.342 & \\
\hline tdeN-fmn & $\mathrm{t}$ & & 0 & 556 & 4210 & 3489 & 8255 \\
\hline potencial de economizar & 0,0 & & 1,0 & 1,0 & 1,0 & 1,0 & \\
\hline total econonizado & $t$ & & 0 & 556 & 4210 & 3489 & 8255 \\
\hline NOVO CONSUMO DE N-fert 4 & $-i$ & & 17079 & 24192 & 224688 & 322805 & 588765 \\
\hline proporcâo N/FMN & ffertt N & & 3,5548 & 3,5548 & 3.5548 & -3.5548 & \\
\hline fertilizante & TFMN & & 60713 & 85998 & 798723 & 1147507 & 2092941 \\
\hline amóniá & tamoniat $F M N$ & & 0,3875 & 0,3875 & 0,3875 & 0,3875 & \\
\hline amônia & t amônia & & 23526 & 33324 & 309505 & 444659 & 811015 \\
\hline energia & Gjitamônia & & 36,89 & 36.89 & 36,89 & 36,89 & \\
\hline energiat & GJ total & & 867882 & 1229335 & 11417639 & 16403472 & 29918327 \\
\hline produtividade com FMN & tha & & 2,113 & 2,787 & 7,431 & 13,005 & 7.272 \\
\hline produtividade total por nivel & tha & & 0,954 & 1,822 & 6,402 & 71,804 & 3,462 \\
\hline
\end{tabular}




\begin{tabular}{|c|c|c|c|c|c|c|c|}
\hline & & & \multicolumn{4}{|c|}{ niveis de produtividade } & dados totais \\
\hline ano 2010 & Unidades & axas (\%a.a) & 0,750 & 1,500 & 4,000 & 7,000 & milfso \\
\hline producáo agricola estimada & tons & $5,03 \%$ & 9057270 & 5940102 & 24943067 & 23181392 & 63121831 \\
\hline area & ha & 0,30 & 7457859 & 2577668 & 2621112 & 1824641 & 14481280 \\
\hline \% area empregando N-FMN & 0,0 & estimado & 0,250 & $0.350^{\circ}$ & 0,900 & 0,950 & 0,474 \\
\hline area útizando $\mathrm{N}-\mathrm{FMN}$ & ha & & 1864465 & 902184 & 2359001 & 1733409 & 6859058 \\
\hline incremento na area com N-FMN & $\%(0.0)$ & & 0,100 & 0.100 & $0,200^{\circ}$ & 0,150 & 0124 \\
\hline produçáo com N-FMN & $-\cdots-i$ & & 4862224 & 3426876 & 23894622 & 22542768 & 54726490 \\
\hline necessidade de N-FMNIt output & $\mathrm{kgNAt}$ output & dado & 18,00 & 18,00 & 18,00 & 18,00 & 18.00 \\
\hline N-FMN aplicado/ha & kgNiha & 6,39 & 33,44 & 68,37 & 182,32 & 234,09 & 139.95 \\
\hline N-FMN TOTAL & tons N-fert & $8,54 \%$ & 62350 & 61684 & 430103 & 405770 & 959907 \\
\hline primeira medida - INCORPORA & & & 0,5 & 0,5 & 0.5 & 0,5 & \\
\hline \% da area nova adotando & 0,0 & & 0,200 & 0.143 & 0,111 & 0,079 & \\
\hline TN-FMN equivalente & $t$ & & 12470 & 8812 & 47789 & 32034 & 101106 \\
\hline$\%$ total de N-fert afetada & 0,0 & & 0,7 & 0.7 & 0,7 & 0,6 & 0,070 \\
\hline t de N-fert & (1) & & 8729 & 6168 & 33452 & 19221 & 67570 \\
\hline potencial de economizar & 0,0 & & 0.15 & 0,15 & 0,15 & 0,20 & 0.012 \\
\hline total economizado & $t$ & & 1309 & 925 & 5018 & 3844 & 11097 \\
\hline NOVO CONSUMO DE N-fert 1 & if & & 61040 & 60759 & 425085 & 401926 & 948810 \\
\hline$\%$ economizada of 1 medida & & & 0,021 & 0.015 & 0,012 & 0,009 & 0,012 \\
\hline unda medida - ADÜBO VEROE & & & & & & & \\
\hline \% da area nova adotando & 0,0 & & 0,200 & 0.143 & 0,111 & 0.079 & \\
\hline i N-FMN equivalente & $t$ & & 12470 & 8812 & 47789 & 32034 & 101106 \\
\hline$\%$ total de N-fert. afetadal & 0,0 & & 1,000 & 1.000 & 0,439 & 0,342 & 0,055 \\
\hline t de N-fert! & $\mathrm{t}$ & & 12470 & 8812 & 20969 & 10948 & 53199 \\
\hline potencial de economizar & 0,0 & & 1,0 & 10 & 1,0 & 1,0 & \\
\hline total economizado & $t$ & & 12470 & 8312 & 20969 & 30948 & 53199 \\
\hline NOVO CONSUMO DE N-fert2> & $t$ & & 48570 & 51947 & 404116 & 390978 & 895611 \\
\hline$\%$ economizada $\mathrm{c} / 2^{3}$ medida & 0,0 & & 0,200 & 0,143 & 0,049 & 0,027 & 0,055 \\
\hline \% econonizada total & 0.0 & & 0.221 & 0,158 & 0,060 & 0,036 & 0,067 \\
\hline area utilizando adubo verde & ha & & 372893 & 128883 & 262111 & 136848 & 900736 \\
\hline$\%$ & & & 0,0500 & 0,0500 & 0,1000 & 0,0750 & 0,0622 \\
\hline INCORPORAR & ha & 0,08 & 0 & 16635 & 78937 & 65418 & 160990 \\
\hline t $N-F M N$ equivalente & & & 0 & 1137 & 14392 & 15313 & 30843 \\
\hline \% total de N-fert afetada & 0,0 & & 0,7000 & 0,7000 & 0,3500 & 0,2400 & 0,010 \\
\hline tde N-fmn & & & 0 & 796 & 5037 & 3675 & 9509 \\
\hline potencial de economizar & 0,0 & & 0,15 & 0,15 & 0,15 & 0.2 & \\
\hline total economizado & $t$ & & 0 & 119 & 756 & 735 & 1610 \\
\hline NOVO CONSUMO OE N-fert 3 & $t$ & & 48570 & 51827 & 403361 & 390243 & 894001 \\
\hline ADÜBÖ VERDE & ha & 0.08 & 0 & 16635 & 78937 & 65418 & \\
\hline IN-FMN equivalente & $t$ & & 0 & 1137 & 14392 & 15313 & 30843 \\
\hline of talal de N-fert afeiada & 0,0 & & 1,000 & 1,000 & 0,439 & 0.342 & \\
\hline t de N-fmn & it & & 0 & 1137 & 6315 & 5233 & 12686 \\
\hline potencial de economizar & $0, \overline{0}$ & & 1,0 & 1,0 & 1,0 & 1,0 & \\
\hline total economizado & t & & 0 & 1137 & 6315 & 5233 & 12686 \\
\hline NOVO CONSUMO DE N-fert4s & t & & 48570 & $50690^{\circ}$ & 397046 & 385009 & 881315 \\
\hline proporca No N/FMN & tfertit N & & 3,5548 & 3.5548 & 3,5548 & 3,5548 & \\
\hline fertilizante & $t F M N$ & & 172658 & 180192 & 1411419 & 1308631 & 3132900 \\
\hline "'momonía & tamoniat FMN & & 0,3875 & 0,3875 & 0,3875 & 0,3875 & \\
\hline amb́nia & tamônia & & 66905 & 69824 & 546925 & 530345 & 1213999 \\
\hline energia & GJttamónia & & 36,89 & 36,89 & 36,89 & 36,89 & \\
\hline energa & GJitail & & 2463129 & 2575822 & 20176053 & 19564414 & 44784418 \\
\hline produtividade com FMN & vha & & 2,608 & 3,798 & 10,129 & 13,005 & 7,979 \\
\hline produtividade total por nivel & & & 1,214 & 2,304 & 9,516 & 12,705 & 4,359 \\
\hline
\end{tabular}


ANEXO - 6 
custo do adubo verde comprando semente todo ano
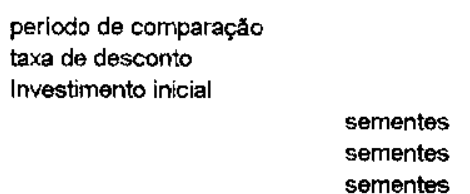

Op. \& man.

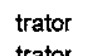

trator

trator

outros

outros

CECF

$\mathrm{kg} \mathrm{N}$ econ/ha

preço fert.

total

CWA

$$
\text { I*FRC + O\&M - CECF }
$$

$1 F R C=i\left(1-(1+i)^{n}-N\right]$

$2 F R C=r\left\{\left[1-(1+r)^{n}-w\right]\right.$

onde:

$i=$ taxa de desconto

$\mathrm{N}=$ periodo de análise

$r=$ taxa de desconto efetiva: $(1+i)^{\wedge} \mathrm{g}-1$

$g=N / w$, número de reposiçסes

$w=$ vida útil do equipamento

1 ano

$\begin{array}{lcc}g= & 10 & \\ r= & 1,59374246 & \\ \text { FRC2 } & 2,59374246 & \\ \text { FRC2.1 } & 207,4993968 \text { U\$/ha } & \\ \text { O\&M } & 9,2885 \text { U\$/ha } & \\ \text { CECF } & 58,85470085 \text { U\$/ha } & \\ \text { CCVA } & 157,933196 \text { U\$/ha } & \text { Considerando custo evitado } \\ \text { CNE } & 1,128094257 \text { U\$/ha } & \text { considerando custo evitado } \\ \text { CCVA } & 216,7878968 \text { U\$/ha } & \text { sem considerar custo evitado } \\ \text { CNE } & 1,548484977 \text { U\$/kgN.ha } & \text { sem considerar custo evitado }\end{array}$

espécie: CROTALÁRIA

$$
\begin{aligned}
& 10 \text { anos } \\
& 10 \% \text {..a. } \\
& 2 \mathrm{Us} / \mathrm{kg} \\
& 40 \mathrm{~kg} \mathrm{semente/ha} \\
& 80 \mathrm{U} \$ \mathrm{ha}
\end{aligned}
$$

$14,29 \cup \$ / h$

9,2885 US/ha

USh

horas/ha

$140 \mathrm{kgN} / \mathrm{ha}$

0,42039072 U $\$ / \mathrm{kgN}$ base uréia

58,85470085 US/ha

pg.57num276Agrianual98

(n)

|

| custo do adubo verde comprando semente de cinco em cinco anos

$\begin{array}{llc}\begin{array}{l}\text { periodo de comparação } \\ \text { taxa de desconto }\end{array} & 10 \text { anos } \\ \text { Investimento inicial } & & 10 \% \mathrm{a.a} . \\ & \text { sementes } & 2 \mathrm{US} / \mathrm{kg} \\ & \text { sementes } & 40 \mathrm{~kg} s e m e n t e / h a \\ & \text { sementes } & 80 \mathrm{US} / \mathrm{ha}\end{array}$

Op. \& man.

trator
trator
trator
outros
outros
outros

CECF

$\mathrm{kg} \mathrm{N}$ econiha
preço fert.

preço fert. $\quad 0,42030072 \mathrm{kgN} / \mathrm{ha}$

0,42039072 US $/ \mathrm{kgN}$ 58,85470085 US/ha

base uréia

CVVA

I"FRC + O\&M - CECF

1 $F R C=i\left[1-(1+i)^{n}-N\right]$

2 FRC $=r /\left[1-(1+r)^{n}-w\right]$

onde:

$i=$ taxa de desconto

$\mathrm{N}=$ periodo de análise

$r=$ taxa de desconto efetiva: $(1+i)^{\wedge} g-1$

$g=N / w$, número de reposiçðes

$w=$ vida útil do equipamento

5 ano

$\begin{array}{lcl}g= & 2 & \\ r= & 0,21 & \\ \text { FRC2 } & 0,341765329 & \\ \text { FRC2*I } & 27,34122634 \text { US/ha } & \\ \text { O\&M } & 9,2885 \text { US/ha } & \\ \text { CEFC } & 58,85470085 \text { US/ha } & \\ \text { CWNA } & -22,2249745 \text { US/ha } & \text { considerando custo evitado } \\ \text { CNE } & -0,15874982 \text { US/ha } & \text { considerando custo evitado } \\ \text { CWA } & 36,62972634 \text { US/ha } & \text { sem considerar custo evitado } \\ \text { CNE } & 0,261640902 \text { US/kgN.ha } & \text { sem considerar custo evitado }\end{array}$


custo do adubo verde comprando semente todo ano

\section{periodo de comparaçăo}

taxa de desconto

Investimento inicia

$\begin{array}{ll} & 10 \text { anos } \\ & 10 \% \text { a.a. } \\ & 2 \mathrm{U} / \mathrm{kg} \\ \text { sementes } & 20 \mathrm{~kg} \mathrm{semente/ha} \\ \text { sementes } & 40 \mathrm{US} / \mathrm{ha}\end{array}$

Op. \& man.

trator

trator

trator

outros

outros

CECF

$\mathrm{kg} \mathrm{N}$ econ/ha

preço fert.

total

CWA

I*FRC + O\&M - CECF 1) $F R C=U\left[1-(1+i)^{n}-N\right]$ $2 \mathrm{FRC}=\mathrm{r} /\left[1-(1+r)^{\wedge}-w\right]$

onde:

$i=$ taxa de desconto

$\mathrm{N}=$ periodo de análise

$r=$ taxa de desconto efetiva: $(1+i)^{\wedge} g-1$

$g=N / w$, número de reposiçठ̄es

$\mathrm{w}=$ vida útil do equipamento

$\mathrm{g}=$

$r=\quad 1.59374246$

FRC2 259374246

FRC2*I $\quad 103,7496984$ U\$/h

$\begin{array}{lr}\text { FRC2*I } & 103,7496984 \text { U\$/ha } \\ \text { O\&M } & 9,2885 \text { U\$/ha }\end{array}$

CECF $\quad 29,42735043$ U\$/ha

CWA 83,61084798 U\$/ha

CNE $\quad 1,194440685$ US/ha

CWA 11,0381984 US/ha

CNE

1,614831406 US/kgN.h espécie: CROTALÁRIA

$14,29 u \$ \mathrm{~s} / \mathrm{h}$

0,65 horas $/$ ha

9,2885 U\$/ha

$$
\text { U\$h }
$$

Uoras/ha

pg.57num276Agrianual98

$70 \mathrm{kgN} / \mathrm{ha}$

$0,42039072 \mathrm{US} / \mathrm{kgN}$ base uréia

29,42735043 u\$/ha

ano
custo evitado
custo evitado
ar custo evitado

$$
\text { |cust }
$$

usto do adubo verde comprando semente de cinco em cinco anos

espécie: CROTALÁRIA

\section{periodo de comparaçă \\ taxa de desconto \\ 10 anos \\ sementes sementes}

Op. \& man.

trator

trator

trator

outros

outros

CECF

\section{$\mathrm{kg} \mathrm{N} \mathrm{econ/ha} \quad 70 \mathrm{kgN} / \mathrm{ha}$ \\ preço fert. $\quad 0,42039072 \mathrm{US} / \mathrm{kgN}$}

total

29,42735043 UStha

base uréia

CWA

I*FRC + O\&M - CECF
$1 \mathrm{FRC}=\mathrm{i} /\left[1-(1+\mathrm{i})^{n}-\mathrm{N}\right]$

2 FRC $=r /\left[1-(1+r)^{n}-w\right]$

onde:

i= taxa de desconto

$\mathrm{N}=$ periodo de análise

$r=$ taxa de desconto efetiva: $(1+i)^{\wedge} \mathrm{g}-1$

$g=N / w$, número de reposiçठes

$w=$ vida útil do equipamento

5 ano $\mathrm{g}=$

FRC2 $\quad 0,21$

FRC2 10,341765329

$\begin{array}{lr}\text { O\&M } & 9,3,6785 \text { US/ha }\end{array}$

98,2885 USha

CEF 29,42735043 USha

CWA $\quad 6,46823725$ UStha

CWA 22,95911317 US/ha

CNE
CNE $\quad-0,09240339 \mathrm{US} / \mathrm{ha}$

\section{considerando custo evitado}

considerando custo evitado

sem considerar custo evitado 
custo do adubo verde comprando semente todo ano

período de comparação
taxa de desconto
Investimento inicial

taxa de desconto
Investimento inicial

sementes
sementes
sementes

Op. \& man.

\section{trator}

trator
trator
trator
outros

outros

outros

CECF

\section{$\mathrm{kg} \mathrm{N}$ econ/ha \\ preço fert.}

total

CWA

$I^{\star} F R C+O \& M-C E C F$

$1 F R C=i\left[\left(1-(1+i)^{\wedge}-N\right]\right.$

2 FRC $=r /\left[1-(1+r)^{\wedge}-w\right]$

onde:

$i=$ taxa de desconto

$\mathrm{N}=$ período de análise

$r=$ taxa de desconto efetiva: $(1+i)^{\wedge} g-1$

$\mathrm{g}=\mathrm{N} / \mathrm{w}$, número de reposiçठes
$\mathrm{w}=$ vida útil do equipamento

$\mathrm{g}=$

2,59374246

O\&M $\quad 9,29$ Us/ha

CECF $\quad 37,84$ U\$/ha

CWA 86,87 U\$/ha

$\begin{array}{lr}\text { CNE } & 0,97 \text { US/ha } \\ \text { CWA } & 124,71 \text { US/ha }\end{array}$

CNE $\quad 1,39$ U\$/kgN.ha

considerando custo evitado

considerando custo gvitado

sem considerar custo evitado

1,39 U\$ $/ \mathrm{kgN}$.ha sem considerar custo evitado

espécie: GUANDU
10 anos

$0,89 \cup \$ / \mathrm{kg}$

$44.5 \mathrm{~kg}$ semente/ha

$14,29 \mathrm{US} / \mathrm{h}$ 9,2885 US/ha

U\$/h

horas

$90 \mathrm{kgN} / \mathrm{ha}$ 37,84 U\$/ha

\section{base uréia}

g. 57num276Agrianual98

base uréia

1 ano custo do adubo verde comprando semente de cinco ern cinco anos

espécie: GUANDU

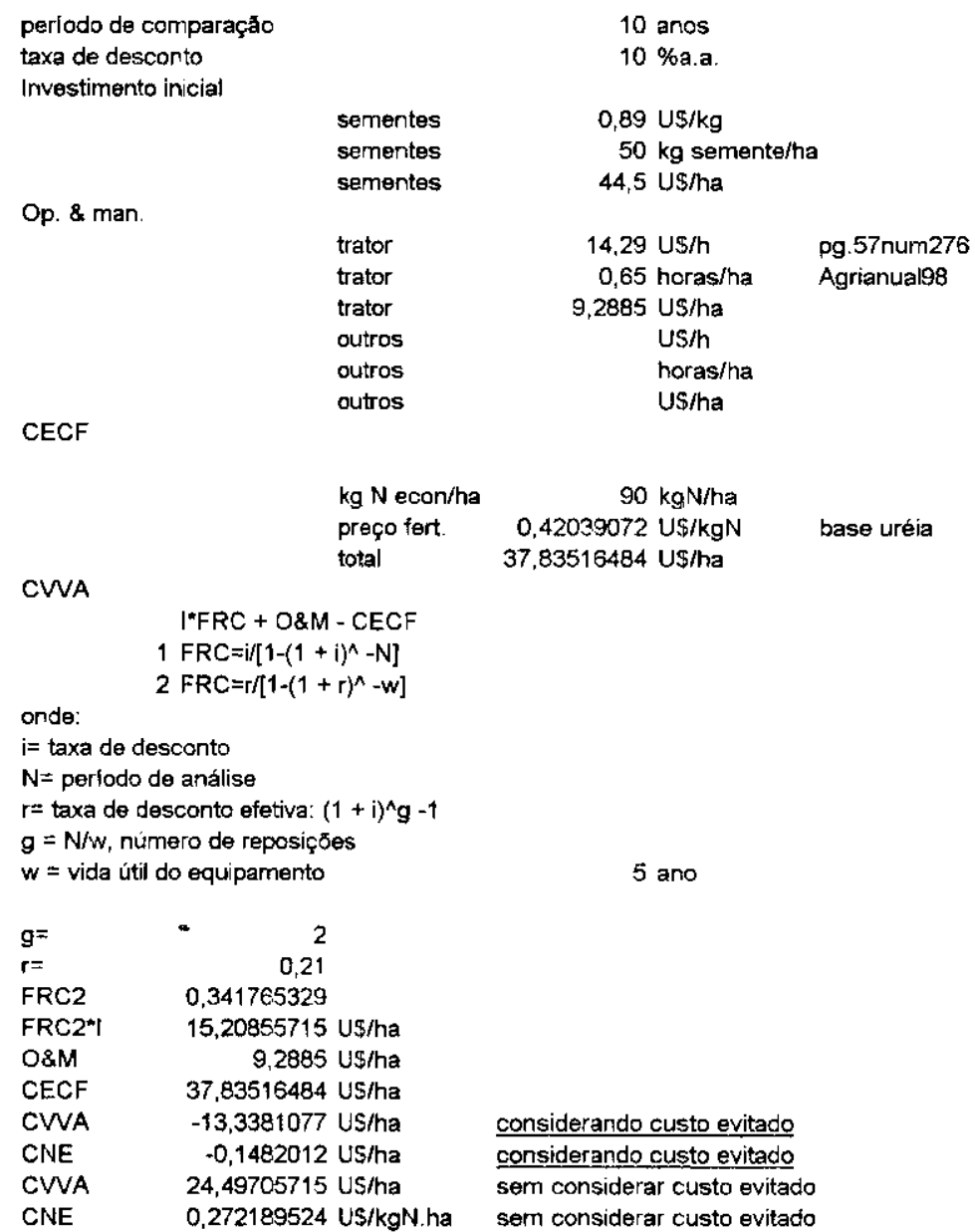


espécie: GUANDU

período de comparaçăo

taxa de desconto

Investimento inicial

$$
10 \text { anos }
$$

0,89 u $\$ / \mathrm{kg}$

sementes

sementes

Op. \& man

trator

trator
trator

trator
outros

outros

outros

CECF

$\mathrm{kg} \mathrm{N}$ өcon/ha

preço fert. $0.42039072 \mathrm{US} / \mathrm{kgN}$ base uréia

CWA

22,25 U\$ $\$$ ha

14,29 U $\$ \mathrm{~h} / \mathrm{h}$
0,65 horash

0,65 horas

U\$/h

horas/ha

U\$/ha

preço fert.

$39072 \mathrm{US} / \mathrm{kgN}$

base uréia
I*FRC + O\&M - CECF

$1 F R C=i\left(1-(1+i)^{n}-N\right]$

2 FRC $=r /\left[1-(1+r)^{n}-w\right]$

onde

$=$ taxa de desconto

$\mathrm{N}=$ periodo de análise

ro taxa do desconto efetiva: $(1+i)^{\wedge} g-1$

$=N / w$, nuf aro de reposiçరes

$w=$ vida útil do equipamento

1 ano

$\begin{array}{lcl}g= & 10 & \\ r= & 1,59374246 & \\ \text { FRC2 } & 2,59374246 & \\ \text { FRC2*1 } & 57,71076974 \text { U\$/ha } & \\ \text { O\&M } & 9,2885 \text { U\$/ha } & \\ \text { CECF } & 18,91758242 \text { U\$/ha } & \\ \text { CWA } & 48,08168732 \text { U\$/ha } & \text { considerando custo evitado } \\ \text { CNE } & 1,06848194 \text { U\$/ha } & \text { considerando custo evitado } \\ \text { CWA } & 66,99926974 \text { U\$/ha } & \text { sem considerar custo evitado } \\ \text { CNE } & 1,488872661 \text { U\$/kgN.ha } & \text { sem considerar custo evitado }\end{array}$

pg.57num276Agrianual98

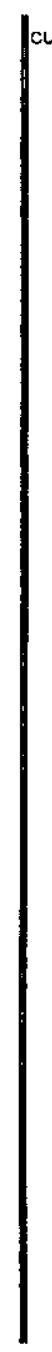

espécie: GUANDU

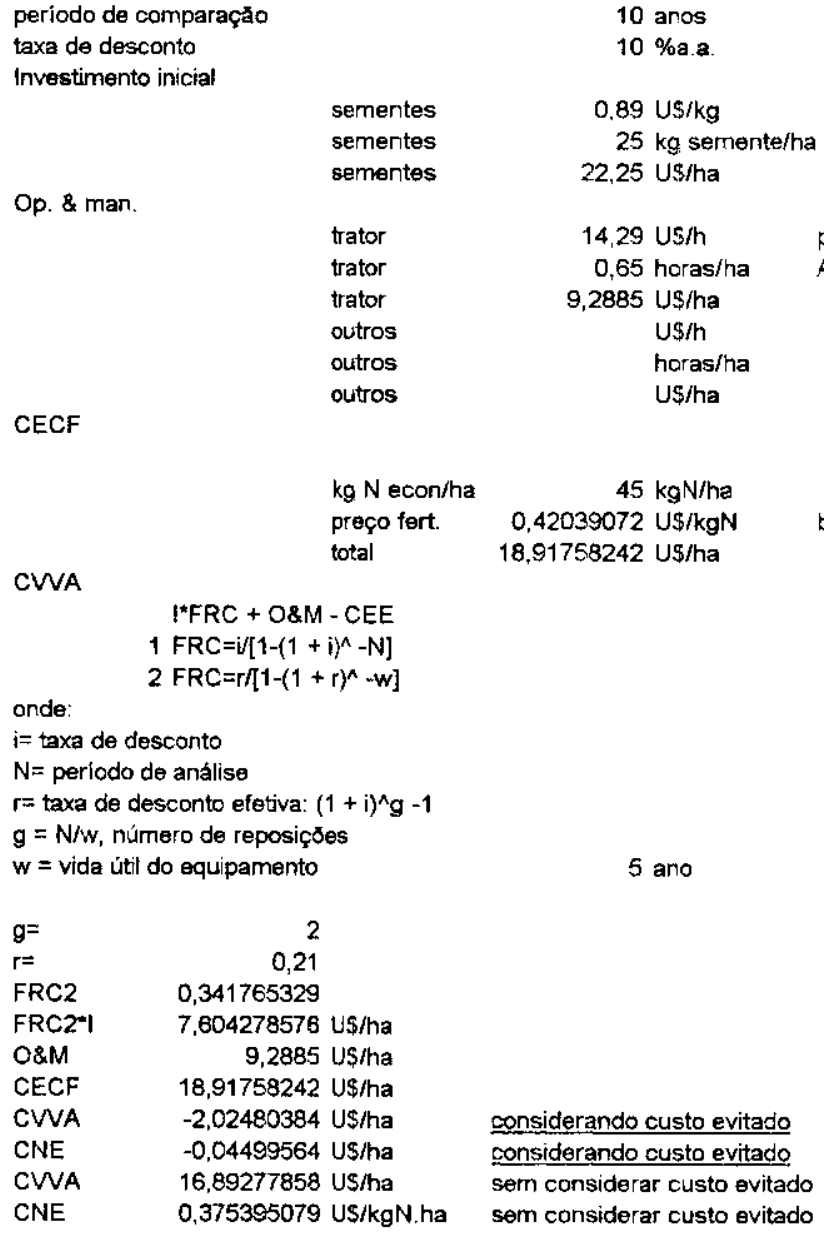


custo do adubo verde comprando semente todo ano

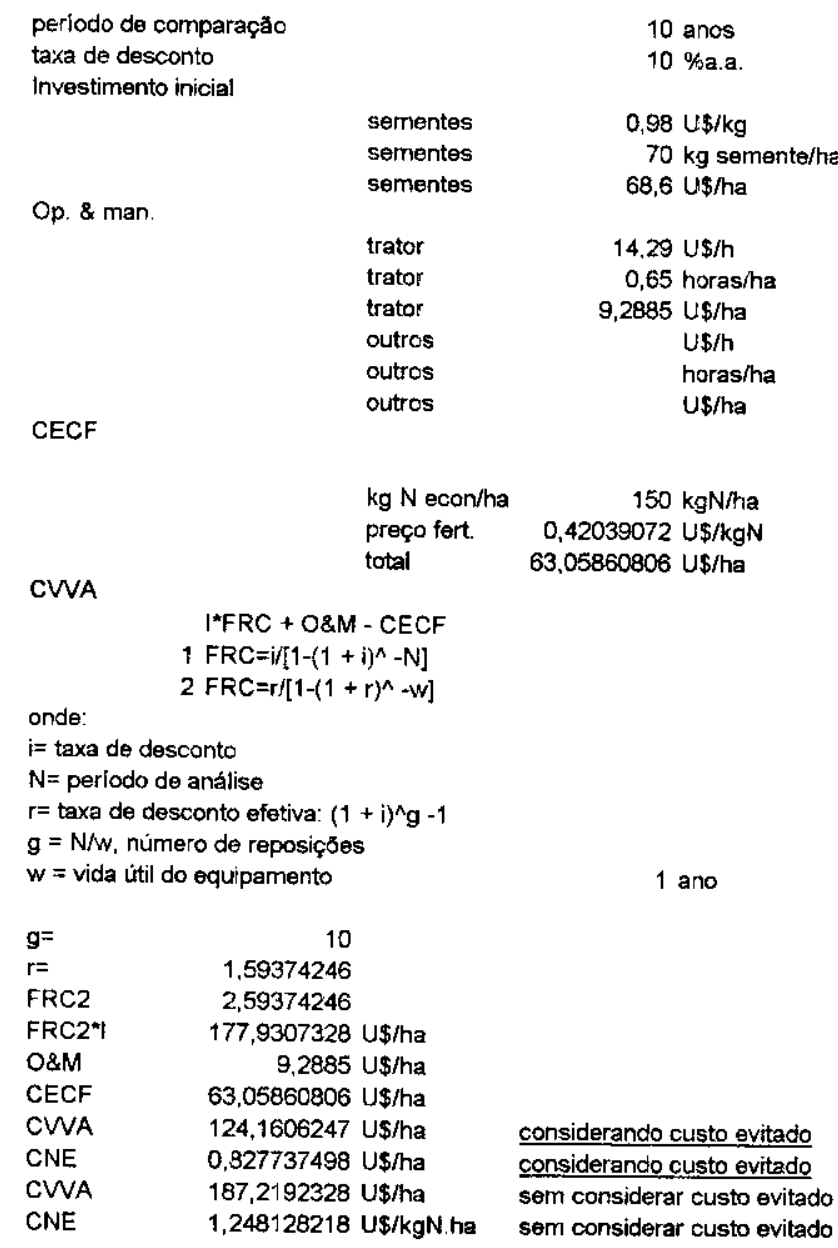

\section{custo do adubo verde comprando sernente de cinco em cinco anos}

espécie: MUCUNA

10 ancos

taxa de desconto

$10 \%$ a.a.

Investimento inicial

0,98 U\$ $/ \mathrm{kg}$

sementes

sementes

Op. \& man.

trator

trator

trator
outros

outros

outros

Custo epec. economizado

base uréia

\section{$\mathrm{kg} \mathrm{N}$ econ/ha}

preço fert.

total

$68,6 \mathrm{U} \$ \mathrm{ha}$

14,29 U\$/h

0,65 horas $/$ ha

9,2885 U\$/ha

U\$/h

horas/na

U\$/ha

CWA

$$
\begin{array}{r}
150 \mathrm{kgN} / \mathrm{ha} \\
0,42039072 \mathrm{US} / \mathrm{kgN} \\
63,05860806 \text { U\$/ha }
\end{array}
$$

IFFRC + O\&M - CECF

$1 F R C=i\left[\left(1-(1+i)^{n}-N\right]\right.$

2 FRC $=r /\left[1-(1+r)^{\wedge}-w\right]$

onde:

i= taxa de desconto

$\mathrm{N}=$ período de análise

$r=$ taxa de desconto efetiva: $(1+i)^{\wedge} g-1$

$g=N / w$, número de reposiçōes

$w=$ vida útil do equipamento

5 ano

$\mathrm{g}=$

0,21

FRC2 $\quad 0,341765329$

FRC2*I 23,44510159 U\$/ha

O\&M $\quad 9,2885$ U\$/ha

CECF $63,05860806 \mathrm{U} \$ \mathrm{ha}$

CWA $\quad-30,3250055$ U\$ ha

CNE $\quad-0,20216671$ U\$/ha

CWA 32,73360159 U\$/ha

sem considerar custo evitado

$0,218224011 \mathrm{U} \$ / \mathrm{kgN}$. ha sem considerar custo evitado 
custo do adubo verde comprando semente todo ano

periodo de comparaçăo

taxa de desconto

Investimento inicial

sementes
sementes

sementes

Op. \& man

\section{trator}

trator
trator

trator

outros

CECF

$$
\text { outros }
$$

\section{$\mathrm{kg} \mathrm{N}$ econ/ha}

preço fert.

CWA

I*FRC + O\&M - CECF

$1 \quad F R C=i\left[\left(1-(1+i)^{\wedge}-N\right]\right.$

2 FRC $=r\left[\left[1-(1+r)^{n}-w\right]\right.$

$=$ taxa de desconto

$N=$ período de análise

$=$ taxa de desconto efetiva: $(1+i)^{\wedge} g-1$

$\mathrm{g}=\mathrm{N} / \mathrm{w}$, número de reposiçঠos

$w=$ vida útil do equipamento

1 ano

$\begin{array}{lcc}\mathrm{g}= & 10 & \\ \mathrm{r=} & 1,59374246 & \\ \text { FRC2 } & 2,59374246 & \\ \text { FRC2*1 } & 88,96536638 \mathrm{U} / \mathrm{ha} & \\ \text { O\&M } & 9,2885 \mathrm{U} / \mathrm{ha} & \\ \text { CECF } & 31,52930403 \mathrm{U \$ /ha} & \\ \text { CWA } & 66,72456235 \mathrm{U} / \mathrm{ha} & \text { considerando custo evitado } \\ \text { CNE } & 0,889660831 \text { U\$/ha } & \text { considerando custo evitado } \\ \text { CWNA } & 98,25386638 \mathrm{U} / \mathrm{ha} & \text { sem considerar custo evitado } \\ \text { CNE } & 1,310051552 \text { U\$/kgN.ha } & \text { sem considerar custo evitado }\end{array}$

espécie: MUCUNA

10 anos

$0,98 \mathrm{u} \$ / \mathrm{kg}$

$35 \mathrm{~kg}$ semente/ha

34,3 Us/ha

pg. 57 num 276

0,65 horasith

Agrianual98

$$
\mathrm{U} \$ \mathrm{~h} / \mathrm{h}
$$

horas $/$ ha

U\$/ha

\section{$0,42030072 \mathrm{kgN} / \mathrm{ha}$ \\ 31,52930403 us/ha \\ base uréia}

|custo do adubo verde comprando semente de cinco em cinco anos

espécie: MUCUNA

periodo de comparação

taxa de desconto

10 anos

$10 \%$ a.

$\begin{array}{llc} & \text { sementes } & 0,98 \mathrm{U} \$ / \mathrm{kg} \\ \text { sementes } & 35 \mathrm{~kg} \text { semen } \\ & \text { sementes } & 34,3 \mathrm{U} / \mathrm{ha} \\ & & \\ \text { Op. \& man. } & \text { trator } & 14,29 \mathrm{U} \$ \mathrm{~h} \\ & \text { trator } & 0,55 \mathrm{horas} / \mathrm{ha} \\ & \text { trator } & 9,2885 \mathrm{U} \$ / \mathrm{ha} \\ & \text { outros } & \text { U\$/h } \\ & \text { outros } & \text { horas/ha } \\ & \text { outros } & \text { U\$/ha }\end{array}$

CECF

$\begin{array}{lr}\mathrm{kg} \mathrm{N} \text { ocon/ha } & 75 \mathrm{kgN} / \mathrm{ha} \\ \text { preço fert. } & 0,42039072 \mathrm{U} \$ / \mathrm{kgN} \\ \text { total } & 31,52930403 \mathrm{U} \$ / \mathrm{ha}\end{array} \quad$ base uréia

CWA

ase uréla

RC + O\&M - CECF

$F R C=i\left[1-(1+i)^{\wedge}-N\right]$

2 FRC $\left.=r[1]-(1+r)^{\wedge}-w\right]$

onde:

$i=$ taxa de desconto

$r=$ taxa de desconto efetiva: $(1+i)^{\wedge} g-1$

$g=N / w$, número de reposiçбes

$w=$ vida útil do equipamento

$$
5 \text { ano }
$$

$\mathrm{g}=$

$\begin{array}{lr}r= & 0,21 \\ \text { FRC2 } & 0,341705329\end{array}$

FRC2 $\quad 0,341765329$

FRC2*1 11,72255079 US/ha

O\&M 9,2885 U\$/ha

CECF $\quad 31,52930403 \mathrm{US} / \mathrm{ha}$

CWVA $\quad-10,5182532$ U\$/ha

CNE $\quad-0,14024338$ U\$/ha

CWA 21,01105079 U\$/ha

CNE $\quad 0,280147344$ U\$ $/ \mathrm{kgN}$. 
custo do adubo verde comprando semente todo ano

período de comparaçăo

$$
\text { taxa de desconto }
$$

Investimento inicial

sementes
sementes
sementes

Op. \& man.

trator

trator
trator

trator
outros

outros

outros

CECF

$\mathrm{kg} \mathrm{N}$ econ/ha $\quad 120 \mathrm{kgN} / \mathrm{ha}$

preço fert. $\quad 0,42039072 \mathrm{U \$} / \mathrm{kgN}$

base urèia

CWA

espécie: FEIJÃO-DE-PORCO

\section{0 anos}

0,77 us/kg

$14,29 \mathrm{U} \$ \mathrm{~h} / \mathrm{h}$

0,65 horas/ha
9,2885 us/he

9,2885 US/ha

U $\$ / h$
horas/ha

U\$/ha

50,44688645 U\$/h
$140 \mathrm{~kg}$ semente/ha

INFRC + O\&M - CECF

$1 F R C=i\left[1-(1+i)^{n}-N\right]$

1 FRC $=r /\left[1-(1+r)^{\wedge}-w\right]$
(1)

onde:

$i=$ taxa de desconto

$\mathrm{N}=$ periodo de análise

$r=$ taxa de desconto efetiva: $(1+i)^{\wedge} g-1$

$g=N / w$, número de reposiç̧es

$w=$ vida útil do equipamento

1 ano

$\begin{array}{lcc}g= & 10 & \\ r= & 1,59374246 & \\ \text { FRC2 } & 2,59374246 & \\ \text { FRC2*1 } & 279,6054372 \text { U\$/ha } & \\ \text { O\&M } & 9,2885 \text { U\$/ha } & \\ \text { CECF } & 50,44688645 \text { U\$/ha } & \\ \text { CWA } & 238,4470508 \text { U\$/ha } & \text { considerando custo evitado } \\ \text { CNE } & 1,987058756 \text { U\$/ha } & \text { considerando custo evitado } \\ \text { CWA } & 288,8939372 \text { U\$/ha } & \text { sem considerar custo evitado }\end{array}$

custo do adubo verde comprando semente de cinco em cinco anos

espécie: FEIJÃO-DE-PORCO

base uréia

período de comparação

taxa de desconto

Investimento inicia

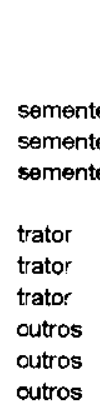

CECF

$\mathrm{kg} \mathrm{N}$ econ/ha $\quad 120 \mathrm{kgN} / \mathrm{ha}$

preço fert. $\quad 0,42039072 \mathrm{U \$} / \mathrm{kgN}$

50,44688645 U\$/ha

CWA

$$
\text { I*FRC + O\&M - CECF }
$$

$1 \quad F R C=i\left[1-(1+i)^{n}-N\right]$

onde:

$2 F R C=r\left[\left[1-(1+r)^{n}-w\right]\right.$

$\mathrm{i}=$ taxa de desconto

$\mathrm{N}=$ periodo de análise

$r=$ taxa de desconto efetiva: $(1+i)^{\wedge} g-1$

$g=N / w$, número de reposiçбes

$w=$ vida útil do equipamento $g=$

FRC2 $\quad 0,341765329$

FRC2*1 36,84230249 US/ha

O\&M $\quad 9,2885$ U\$/ha

50,44688645 U\$/ha

CWA -4,31608395 U\$/ha

CNE $\quad-0,03596737$ US/ha

CNE $\quad 0,384423354$ U\$/kgN.ha
10 anos

$0,77 \mathrm{U} \$ / \mathrm{kg}$

$140 \mathrm{~kg}$ semente/ha

107,8 U\$/ha

U\$h

2885 U\$/ha

Us/h

(\$)

horas $/ 1$

sem considerar custo evitado 
espécie: FEIJÃO-DE-PORCO

\section{periodo de comparaçăo}

taxa de desconto

Investimento inicial

$$
10 \text { anos }
$$

\section{sementes}

\section{sementes}

$0,77 \mathrm{us} / \mathrm{kg}$

53,9 us/hante/h

Op. \& man.

$\begin{array}{lc}\text { trator } & 14,29 \text { U\$/h } \\ \text { trator } & 0,65 \text { horas/ha } \\ \text { trator } & 9,2885 \text { U\$/ha } \\ \text { outros } & \text { U\$/h } \\ \text { outros } & \text { horas/ha } \\ \text { outros } & \text { U\$/ha }\end{array}$

CECF

\section{$\mathrm{kg} \mathrm{N}$ econ/ha $\quad 60 \mathrm{kgN} / \mathrm{ha}$}

preço fert. $\quad 0,42039072 \mathrm{U \$} / \mathrm{kgN}$ base uréia total 25,22344322 US/ha

CWA

NFRC + O\&M - CECF $1 F R C=i /\left[1-(1+i)^{\wedge}-N\right]$

$2 \mathrm{FRC}=\mathrm{r}\left[1-(1+r)^{\wedge}-w\right]$

onde:

$\mathrm{j}=$ taxa de dosconto

$\mathrm{N}=$ periodo de análise

$r=$ taxa de desconto efetiva: $(1+i)^{\wedge} \mathrm{g}-1$

$g=N / w$, número de reposiçঠes

$w=$ vida útil do equipamento

$g=$

10
1,59374246

FRC2 2,59374246

FRC2*I 139,8027186 U\$/ha

O\&M 9,2885 U\$/ha

CECF 25,22344322 U\$/ha

CWA $123,8677754 \mathrm{U} \$ / \mathrm{ha}$

CNE $\quad 2,064462923 \mathrm{U \$} / \mathrm{ha}$

CVA $\quad 149,0912186$ U\$ $/ \mathrm{ha}$

CNE nsiderando custo evitad

considerando custo evitado

sem considerar custo ovitado

sem considerar custo evitado feusto do adubo verde comprando semente de cinco em cinco anos

espécie: FEIJÃO-DE-PORCO

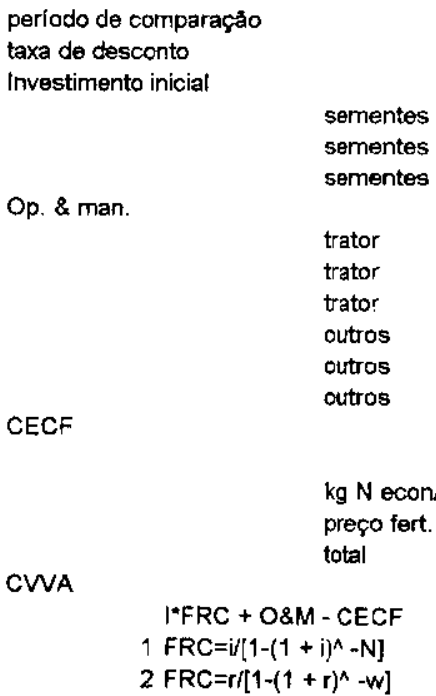

onde:

$\mathrm{i}=$ taxa de desconto

$\mathrm{N}=$ período de análise

$=$ taxa de desconto efetiva: $(1+i)^{\wedge} \mathrm{g}-1$

$g=N / w$, número de reposiçסes

$w=$ vida útil do equipamento

5 ano

$\begin{array}{lcc}g= & 2 & \\ r= & 0,21 & \\ \text { FRC2 } & 0,341765329 & \\ \text { FRC2*1 } & 18,42115125 \text { U\$/ha } & \\ \text { O\&M } & 9,2885 \text { US/ha } & \\ \text { CECF } & 25,22344322 \text { U\$/ha } & \\ \text { CWVA } & 2,486208023 \text { US/ha } & \text { considerando custo evitado } \\ \text { CNE } & 0,0414368 \text { US/ha } & \text { considerando custo evitado } \\ \text { CWA } & 27,70965125 \text { US/ha } & \text { sem considerar custo evitado } \\ \text { CNE } & 0,461827521 \text { U\$/kgN. ha } & \text { sem considerar custo ovitado }\end{array}$




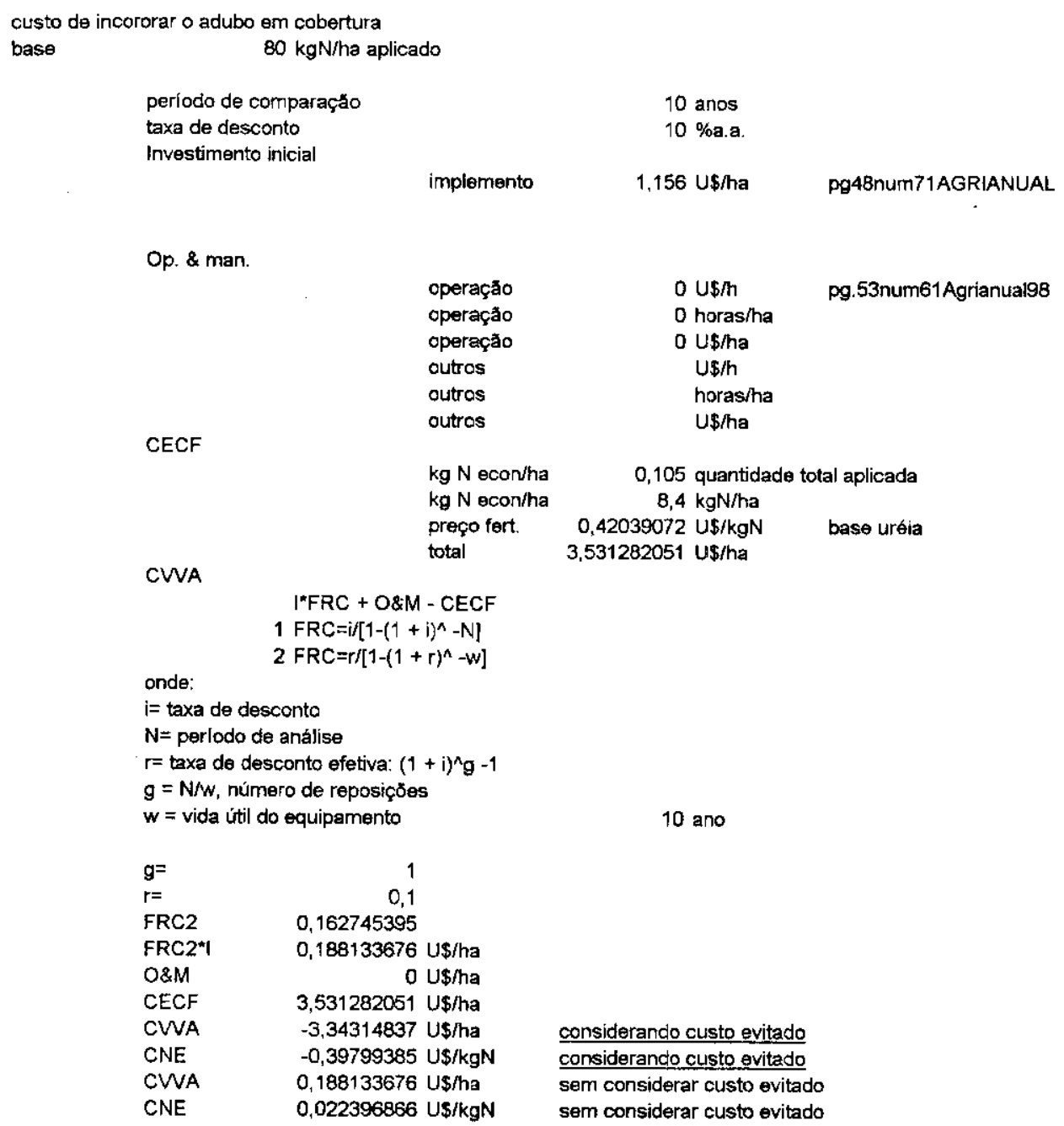




\section{REFERÊNCIAS BIBLIOGRÁFICAS}

AAO. Primeiro Levantamento Agroecológico do Estado de São Paulo. Relatório Final. São Paulo, 1992. 242p. (mimeografado).

ABIQUIM. Anuário Estatístico da Indústria Química, 1996.

ABBOUD, A.C.S.; DUQUE, F.F. Caracterização de Leguminosas com Potencial para Adubação Verde no Periodo da Seca. In: Congresso Brasileiro de Ciência do Solo, 24. Goiânia, 1993. Resumos. Goiânia, 1993. Res. 446.

ABRASEM. Anuário Estatístico do Setor de Sementes, 1997.

AGENDA 21. Conferência das Naçōes Unidas sobre Meio Ambiente e Desenvolvimento - 1992. Publicado por Governo do Estado de São Paulo, Secretaria do Meio Ambiente. 1995.

ANDA. Anuário Estatistico do Setor de Fertilizantes, 1988 a 1996.

ANJOS, J.T. \& TEDESCO, M.J. Perdas de Nitrogênio por Volatilização de Amônia, Proveniente da Uréia Aplicada em solos Cultivados. In: Congresso Brasileiro de Ciência do Solo, 14. Santa Maria, 1973. Anais. !974. p232-41.

ARAUJO, J.L.R.H. Modelos de Energia para Planejamento. Rio de Janeiro, 1988. Tese (Preparada para Concurso de Professor Titular). COPPE/UFRJ.

AYRES, R.U.; SCHLESINGER, H.; SOCOLOW, R.H. Human Impacts on the Carbon and Nitrogen Cycles. In: SOCOLOW, R.; ANDREWS, C.; BERKHOUT, F.; THOMAS, V. Industrial Ecology and Global Change. Cambrige University Press, 1994.

BALANÇO ENERGÉTICO NACIONAL. 1997. DNDE/SEN/MME.

BARRETO, M.C.V.; GLÓRIA, N.A.; CHITOLINA, J.C. Perdas de Amônia por Volatilização em Três Solos Associadas ao Uso de Aquamônia e Uréia. In: Reunião Brasileira de Fertilidade do Solo e Nutrição de Plantas, 20, Piracicaba, 1992. Anais. Piracicaba, 1992. p.330-31.

BEER, J. de; WORRELL, E.; BLOCK K. Long Term Energy Efficiency Improvements in the Ammonia Industry. In: ACEEE Summer Study on Industry, Buffalo-NY, 1995.

BOLLE, H.J.; SEILER, W.; BOLIN, B. Other Greenhouse Gases and Aerosols: Assessing Their role for Atmospheric Radiative Transfer. In: BOLIN, B.; DÖÖS, BO R.; JÄGER, J.; WARRICK, R.A. The Greenhouse Effect Climatic Change and Ecosystems. SCOPE 29, 1986.

BRADY, N.C. Natureza e Propriedade dos Solos. 6 ed. Rio de Janeiro. Livraria Freitas Bastos, 1983. $647 \mathrm{p}$.

BRAUN, W.A.G. Indústria de Fertilizantes Nitrogenados. In: Simpósio Brasileiro Sobre Nitrogênio em Plantas, 1. Itaguaí, 1993. Anais. Itaguai, 1993. p18-70. 
BRUNO, M.A.C. et al. (coord) Conservação de Energia na Indústria de Fertilizantes - Manual de Recomendaçōes. São Paulo. IPT, 1985.

CALMANOVICl, C.E.; GUARDANI, R.; GIULIETTI, M. Fertilizantes: Indústria para Nutrição de Plantas. Ciência Hoje, vol.10, n57, 1989.

CANTARELLA, $\mathrm{H}$. et al Modos de Aplicação de Fertilizantes Nitrogenados em Milho. In: Reunião Brasileira de Fertilidade do Solo, 18. Guarapari, 1988. Resumos. 1988. p37-8.

CANTARELLA, H. DUARTE, A.P.; RAMOS, V.J.; GALLO, P.B.; BORTOLETTO, N. Adubação NK em Cobertura em Milho. In: Reunião Brasileira de Fertilidade do Solo e Nutrição de Plantas, 21. Petrolina, 1994. Anais. Petrolina, 1994. p. 360-61.

CASTRO, P.R.C.; FERREIRA, S.O.; YAMADA, T. Ecofisiologia da Produção Agrícola. Piracicaba. Associação Brasileira para Pesquisa da Potassa e do Fosfato, 1987.

CEKINSKI, E. et al. (coord.) Tecnologia de Produção de Fertilizantes. São Paulo. IPT, 1990.

CHABARIBERY, D. Tecnologia Socialmente Apropriada: Adubaçāo Verde. São Paulo, 1988. (IEA-Relatório de Pesquisa 01/88).

COSTA, M.B.B. Adubação Verde: Uma Prática Indispensável aos Sistemas Agricolas das Regiöes Tropicais e Sub-Tropicais. 1995. datilografado.

COSTA, M.B.B. (coord.) Adubação Verde no Sul do Brasil. Rio de Janeiro, AS-PTA, 1993.

DE-POLLI, H.; CHADA, S.S. Adubação Verde Incorporada ou em Cobertura na Produção de Milho em Solo de Baixo Potencial de Produtividade. Revista Brasileira de Ciência do Solo. v.13, n.3, p.287-93, 1989.

DIESEL, T.R.D. Aspectos Estruturais e Organizacionais da Indústria Brasileira de Fertilizantes. Viçosa, 1996. Tese (Magister Scientiae). UFV.

DOBEREINER, J. O Nitrogênio na Agricultura Brasileira. In: Simpósio Brasileiro Sobre Nitrogênio em Plantas, 1. Itaguai, 1990. Anais. Itaguai, 1990. p.1-17.

DULLEY, R.D.; MIYASAKA, S. Agricultura Sustentável e Prioridade aos Insumos Agricolas Internos. Informaçōes Econômicas, v24, n.11, 1994.

Energy Use Survey for The Fertilizer Institute, 1985.

EUROPEAN FERTILIZER MANUFACTURES' ASSOCIATION - EFMA. Production of Ammonia: Best Available Techniques for Pollution Prevention and Control in the European Fertilizer Industry. Belgium, 1995 (Booklet no 1).

FANCELLI, A.L. Sistemas de Produçāo. Piracicaba, FEALQUSPISEBRAE, 1994. (Cursos Agrozootécnicos). 
FAO/INCRA. Diretrizes de Politica Agránia e Desenvolvimento Sustentável. INCRA, 1994. (Versão Resumida do Relatório Final do Projeto UTF/BRA/O36).

FEDRIZZI, M.C. Fomecimento de Água com Sistemas de Bombeamento Fotovoltaicos; Dimensionamento Simplificado e Análise de Competitividade para Sistemas de Pequeno Porte. São Paulo, 1997. Dissertação (mestrado) - PIPGE/USP.

FERREIRA, C.R.R.P.T. Fertilizantes Entregues ao Consumidor Final no Brasil, 1987-95. São Paulo, IEA, 1996 (Série Informações Estatisticas da Agricultura).

FERREIRA, C.R.R.P.T.; VEGRO, C.L.R. Sazonalidade da relação de Troca fertilizantes e Produtos Agricolas, Região Centro-Sul, 1989-95. Informaçōes Económicas, v26, n.6, 1996.

FINN, A. Cryogenic Purge Gas recovery Boots Ammonia Plant Productivity and Efficiency. AMMONIA TECHNOLOGY, set-out, n.175, 1988.

FNP-Consultoria \& Comércio. Anuário Estatístico - AGRIANUAL 96, 97 e 98, 1996, 1997, 1998.

FURTADO, R.; BEZERRA, A. Hora da Largada. Globo Rural. Ano13, n.155, setembro/1998.

GOMES, I.C. Uma Análise do Mercado e do Preço Competitivo do Gás Natural em São Paulo. São Paulo, 1996. Dissertação (mestrado) - PIPGENSP.

HEINRICHS, R.; AITA, C.; AMADO, T.J.C.; ZONCANARO, L. Cobertura do Solo e Suprimento de Nitrogênio ao Milho Através do Cultivo Consorciado de Ervilhaca e Aveia Preta. In: Congresso Brasileiro de Ciência do Solo, 24. Goiânia, 1993. Resumos. Goiânia, 1993. Res. 453.

HERCOWITZ, M. Turismo e Desenvolvimento Sustentado. São Paulo, 1997. Monografia de Conclusão de Curso (Graduação). PUC.

HOBBELINK, H. Biotecnologia - muito além da Revoluçâo Verde. Porto Alegre, 1990. 196p.

HOMEM de MELO, F. Uma Proposta de Politica Agrícola para o Brasil. 1996. Datilografado.

HONTI, G.D. Energy Conservation in the Nitrogen Industry. In: The British Sulphur Corporation's Intemational Conference on Fertilizer Technology, London, 1981. Proceedings - Part l: Papers. London, 1981. p01-37.

INSTITUTO BRASILEIRO DE GEOGRAFIA E ESTATÍSTICA. Sinopse Preliminar do Censo Agropecuário. 1987. Rio de Janeiro.

INSTITUTO BRASILEIRO DE GEOGRAFIA E ESTATISTICA. Censo Agropecuário número 19 São Paulo. 1997. Rio de Janeiro.

JARVAN, J. E. Haldor Topsoe Technology for Ammonia Converter Revamp. 1989. (TOPSOE Technologies). 
KINZIG, A.P., SOCOLOW, R.H. Human Impacts on the Nitrogen Cycle. Physics Today, novembro; 1994.

LARA, W.A.R.; OLIVEIRA de D.; MOTTA, S.A. Perdas Gasosas de N-NH 3 Provenientes da Aplicação de Nitrogênio em Cobertura na Cultura do Milho. In: Reunião Brasileira de Fertilidade do Solo e Nutrição de Plantas, 21. Petrolina, 1994. Anais. Petrolina, 1994. p.85-6.

LOPES, A.S.; GUILHERME, L.R.G. Fertilizantes e Corretivos Agricolas: Sugestões de Manejo Para Uso Eficiente. In: Reunião Brasileira de Fertilidade do Solo e Nutrição de Plantas, 20. Piracicaba, 1992. Anais. Piracicaba, 1992. p39-69.

LOPES, A.S. O Uso de Tecnologia Modema como Preservação do Meio Ambiente. In: Simpósio Nacional do Setor de Fertilizantes, 1. São Paulo, 1994. Anais. São Paulo, 1994. p.247-79.

MACHADO, I.C. Greenhouse Gas Emissions and Bio-Ethanol Production/Utilization in Brazil. In: RIBEIRO, S.K.; ROSA, L.P. (editores). South-South North Partership on Climate Change and Greenhouse Gas Emissions. November, 1997 (Special Issue of Energia, Desarrollo y Medio Ambiente - ALAPE).

MALAVOLTA, E. Manual de Química Agrícola. São Paulo, Ceres, 1967.

MALAVOLTA, E. Fertilizantes, Corretivos e Produtividade - Mitos e Fatos. In: Reunião Brasileira de Fertilidade do Solo e Nutrição de Plantas, 20. Piracicaba, 1992. Anais. Piracicaba, 1992. p.89153.

MARTIN, N.B.; SANTOS, Z.A.P.S.; ASSUMPÇÃO, R. Análise Econômica da Utilização da Adubação Verde nas Culturas de Algodão e Soja em Rotação com Milho e Amendoim da Região de Ribeirão Preto. São Paulo, SAA-ESP/IEA, 1982. (Estudo Técnico).

MELLO, F de A.F. de et al Fertilidade do Solo. São Paulo, Nobel, 1983.

MELO, F.B.; CARDOSO, M.J.; ITALIANO, E.C.; RIBEIRO, V.Q. Manejo do Solo com Adubação Verde em Sistemas Isolado e Consorciado com o Milho. In: Reunião Brasileira de Fertilidade do Solo e Nutrição de Plantas, 21. Petrolina, 1994. Anais. Petrolina, 1994. p.241.

MODERN PRODUCTION TECHNOLOGIES. NITROGEN, special issue. 1997.

MONTEIRO, J.A. Caracterização das Estruturas de Produção e Avaliação Sócio conômica da Tecnologia de Produção de Milho e Sorgo. Resumo Publicado na INTERNET: http://www.cnpms.embrapa.br/programa/programa.html. 02/07/1997. (projeto: 04.0.94.270).

MUKHERJEE, S.K. Chemical Technology for Producing Fertilizer Nitrogen in the Year 2000. In: SWAMINATHAN, M.S.; SINHA, S.K. Global Aspects of Food Production. Tycooly Intemational, 1986.

MULCKHUYSE, R.H.; VENKATARAMAN, S. The Potential for Energy Efficiency in the Fertilizer Industry. World Bank Technical Paper, n. 35, Washington, 1985. 
NEPTUNE, A.M.L. Evoluçāo do Consumo de Fertilizantes no Brasil: Caracteristicas e Problemas. Piracicaba, FEALQ-USP, 1986.

OLIVEIRA, M.N.A. Situação e Perspectivas do Milho na Região Sul e no Brasil. In: Congresso Nacional de Milho e Sorgo, 19. Porto Alegre, 1992. Conferências. Porto Alegre, 1992. p.40-68.

OLIVEIRA, E. Efeito da Crotalaria juncea Linn. na Eficiência Agronómica, Econômica e Energética de Culturas em Sucessão sob Plantio Direto. Piracicaba, 1996. Dissertação (mestrado) - ESALQJUSP.

ORGANISATION FOR ECONOMIC CO-OPERATION AND DEVELOPMENT \& INTERNATIONAL ENERGY AGENCY - OECD/EA. Greenhouse Gas Emissions: The Energy Dimension. 1991.

PEREIRA FILHO, I.A.; COELHO, A.M.; CRUZ, J.C. Produtividade de Mitho na Presença e Ausência da Leucena (Leucaena leucacephala) e Niveis de Nitrogênio. In: Congresso Nacional de Milho e Sorgo, 21. Londrina, 1996. Resumos. Londrina, 1996. p.146.

PETROBRÁS. Matérias-primas para a Indústria de Fertilizantes. Cadernos PETROBRÁS no 4. 1980.

POSTGATE, J. Fixação do Nitrogênio. Série Temas de Biologia v.32. São Paulo, E.P.U., 1989, $84 p$.

PRASAD, R. Fertilizer Nitrogen: requirements and management. In: SWAMINATHAN, M.S.; SINHA, S.K. Global Aspects of Food Production. Tycooly Intemational, 1986.

PRIMAVESI, A. Manejo Ecológico do Solo. 6ed. São Paulo. Nobel, 1984.

PUGGINA, W.A. Fertilizer Demand in Brazil: Evolution, Present Situation and Perspectives. In: IFA Annual Conference, 61. Lousiana, 1993. Mimeografado. Lousiana, 1993.

PUGGINA, W.A. A Indústria de Fertilizantes no Brasil: Situação Presente e Perspectivas. In: Simpósio Nacional do Setor de Fertilizantes, 1. São Paulo, 1994. Anais. São Paulo, 1994. p.3566.

RAIJ, B. van Fertilidade do Solo e Adubação. Piracicaba-SP, Editora Agronômica Ceres Ltda., 1991. 343p.

RAIJ, B. van O Baixo Uso de Nitrogênio no Brasil. In: Simpósio Nacional do Setor de Fertilizantes, 1. São Paulo, 1994. Anais. São Paulo, 1994. p127-62.

RAPPEL, E.; LOIOLA, E. Estudo da Competitividade da Indústria Brasileira - Competitividade da Indústria de Fertilizantes. Campinas, MCT/FINEP/PADCT. 1993. (Nota Técnica Setorial do Complexo Químico).

REDDY, A.K., D'SA A., SUMITRA, G. D. Integrated Energy Planning: Part I. The DEFENDUS Methodology. Energy for Sustainable Development, vil, n.3, september 1995. 
REIJNTJES, C. et al. Agricultura para o Futuro. Rio de Janeiro, AS-PTA, 1994, 324p.

SACHS, I. Ecodesenvolvimento: crescer sem destruir. São Paulo, Vértice, 1986. p. 19.

SACHS, I. Espaços, Tempos e Estratégias do Desenvolvimento. São Paulo, Vértice, 1986. p.1729.

SCHNOOR, J.; THOMAS, V. Soil as Vulnerable Environmental System. In: SOCOLOW, R.; ANDREWS, C.; BERKHOUT, F.; THOMAS, V. Industrial Ecology and Global Change. Cambrige University Press, 1994.

SCHLESINGER, W. The Vulnerability of Biotic Diversity. In: SOCOLOW, R.; ANDREWS, C.; BERKHOUT, F.; THOMAS, V. Industrial Ecology and Global Change. Cambrige University Press, 1994.

SECRETARIA DA AGRICULTURA E ABASTECIMENTO DO ESTADO DE SÃO PAULO. Levantamento Censitário de Unidades de Produção Agrícola do ESP - LUPA. Volume 4, 1997.

SERRA, G.E. et al. Avaliação da Energia Investida na Fase Agrícola de Algumas Culturas. São Paulo, USP/FUSP, 1979 (Relatório Final IFUSP/P463).

SMIL, V. Nitrogen and Phosphorus. In: TURNER, I.; CLARK, W.C.; KATES, R.; RICHARDS, J.; MATHEWS, J.; MEYER, W. The Earth as Transformed by Human Actions - global and regional changes in the biosphere over the past 300 years. Cambrige University Press, 1990.

STEWART, J.W.B.; VICTORIA, R.; WOLMAN, M.G. Global Cycles. In: DOOGE, J.C.I. et al. $\boldsymbol{A} n$ Agenda of Science for Environment and Development into the 21st Century. Cambrige University Press, 1992.

Subsidios à Formulação de Política sobre o Uso da Matéria Orgânica na Agricultura Paulista. São Paulo, SAA, 1984 (Relatório Elaborado pelo Grupo de Trabalho Criado pela resolução SAA 005).

SWEDISH ENVIRONMENTAL PROTECTION AGENCY - SEPA. The Greenhouse Gases: Emissions and Countermeasures in an Intemational Perspective. Report 4045, 1991.

TRIVELIN, P.C.O.; LARA CABEZAS, W.A.R.; BOARETTO, A.E. Perda de Amônia do Solo por Volatilização Associada a Aplicação Superficial de Uréia, Nitrato de Amônio e Uran. In: Congresso Brasileiro de Ciência do Solo, 24. Goiânia, 1993. Resumos. Goiânia, 1993. Res. 68.

TSUNECHIRO, A.; FERREIRA, C.R.R.P.T. Aspectos Econômicos da Adubação do Milho no Brasil. Informaçōes Económicas, v26, n.11, 1996.

VILLAS BOAS, R.L.; FERNANDES, D.M.; BOARETTO, A.E. TRIVELIM, P.C.O. Efeito da Uréia, do Sulfato de Amônio e da Mistura de Ambos na Recuperação de N pelo Milho (Zea Mays L.). In: Congresso Brasileiro de Ciência do Solo, 24. Goiânia, 1993. Resumos. Goiânia, 1993. Res.198. 
VITTI, G.C.; MALAVOLTA, E.; COUTINHO, E.L.M. Uso Eficiente de Fertilizantes Nitrogenados e Portadores de Enxofre. In: Simpósio sobre Fertilizantes na Agricultura Brasileira, Brasilia, 1984. Anais. Brasilia, 1984. p205-253.

Why Revamp? NITROGEN, jan-fev, n.147,1984.

WORLD ENERGY COUNCIL. Energy Efficiency Improvement Utilising High Technology - an Assessment of Energy Use in Industry and Biuldings. 1995 (Report \& Case Studies).

WORRELL, E.; BEER, J.G. de Energy Savings in the Nitrogen Fertilizer Industry. FERTILIZER INDUSTRY, p123-132, 1995.

WUTKE, E.B. Adubação Verde: Manejo de Fitomassa e Espécies Utilizadas no Estado de São Paulo. In: Curso sobre Adubação Verde no Instituto Agronômico, 1. Campinas, 1993. Documentos IAC, 35. Campinas, Instituto Agronômico. p17-29.

YAMADA, T. Adubação Nitrogenada do Milho: como Melhorar a Eficiência? Informaçōes Agronómicas, setembro/95, n71, 1995.

YAMADA, T. Adubação Nitrogenada do Milho: Quanto, Como e Quando Aplicar? Informaçōes Agronómicas, junho/96, n74, 1996.

ZARDI, U.; ANTONINI, A.; Ammonia Technology: State of the Art New Developments. NITROGEN, november/december, 1979, n122, 1979. 